\author{
UNIVERSIDADE DE SÃO PAULO \\ FACULDADE DE FILOSOFIA, LETRAS E CIÊNCIAS HUMANAS \\ DEPARTAMENTO DE LÍNGUAS ORIENTAIS
}

\title{
AS CARTILHAS E OS LIVROS DE LEITURA DE LEV N. TOLSTÓI
}

Belkiss Rabello

SÃO PAUL0

2009 


\author{
UNIVERSIDADE DE SÃO PAULO \\ FACULDADE DE FILOSOFIA, LETRAS E CIÊNCIAS HUMANAS \\ DEPARTAMENTO DE LÍNGUAS ORIENTAIS
}

\author{
Belkiss Rabello
}

\title{
AS CARTILHAS E OS LIVROS DE LEITURA DE LEV N. TOLSTÓI
}

\begin{abstract}
Dissertação de Mestrado apresentada ao Programa de Pós-Graduação em Literatura e Cultura Russas do Departamento de Letras Orientais da Faculdade de Filosofia, Letras e Ciências Humanas da Universidade de São Paulo, sob a orientação da Prof $^{\mathrm{a}} \mathrm{Dr}^{\mathrm{a}}$ Elena Vássina.
\end{abstract}

Pesquisa financiada pela Capes

SÃO PAUL0

2009 
Rabello, Belkiss

As cartilhas e os livros de leitura de Lev N. Tolstói / Belkiss Rabello ; orientadora Elena Vássina. -- São Paulo, 2009.

$288 \mathrm{p}$.

Dissertação (Mestrado - Programa de Pós-Graduação em Literatura e Cultura Russa do Departamento de Letras Orientais) - Faculdade de Filosofia, Letras e Ciências Humanas da Universidade de São Paulo.

1. Lev Nikoláievitch Tolstói, 1828-1910. 2. Literatura Russa. 3. Tradução. 4. Não-violência. I. Título. II. Vássina, Elena. 


\section{Dedicatórias}

\section{À memória da minha mãe, minha maior amiga. \\ À memória do meu pai, meu maior amigo. \\ À memória de Lev Tolstói, meu maior sonho.}

\section{E, também, à memória de João Guimarães Rosa,}

meu igual encanto.

Dedico este trabalho também à $\operatorname{Prof}^{\mathrm{a}} \mathrm{Dr}^{\mathrm{a}}$ Aurora F. Bernardini que, com mãos firmes, trouxe-me de volta a esta Universidade. 


\section{Agradecimentos}

À Prof ${ }^{\mathrm{a}}$ Dr $^{\mathrm{a}}$ Elena Vássina, pela paciência com que me ensinou, pelo interesse com que me escutou e pela orientação sempre cuidadosa.

Ao Prof. Dr. Noé Silva, pela leitura destes textos e pelas importantes observações feitas.

Aos funcionários do Departamento de Línguas Orientais, sempre gentis e solícitos.

À Capes, pela Bolsa de Estudos.

A todos aqueles que participaram, contribuindo para a realização deste trabalho, direta ou indiretamente, o meu agradecimento. 
Antes da iluminação, cortar lenha, carregar água.

Depois da iluminação, cortar lenha, carregar água.

Provérbio zen-budista 


\section{Resumo}

A vasta obra de Lev Nikoláievitch Tolstói inclui um intenso trabalho pedagógico. A partir do final da década de 1850, e até o fim de sua vida, Tolstói dedicou-se também a escrever duas cartilhas e quatro livros de leitura, todos empregados na alfabetização do povo russo, durante décadas, não apenas na Escola de Iásnaia Poliana, mas igualmente em várias escolas daquele país. Além de apresentar a tradução do Terceiro Livro de Leitura e de expor algumas das soluções encontradas durante o processo de tradução da referida obra, esta Dissertação procura mostrar a importância desta fase literária de Lev N. Tolstói, ainda pouco conhecida do leitor brasileiro e, em meu entender, essencial para uma melhor compreensão da literatura que ele produziu no período que a crítica literária em geral chamou de "crise" que acometeu o escritor. Optei por acrescentar a tradução da correspondência mantida entre Lev N. Tolstói e Mahatma K. Gandhi porque entendo estar nela, tratada de maneira mais explícita do que em outros textos, a questão da não-violência, essencial, por sua vez, à compreensão da produção literária que inclui sua obra pedagógica.

Palavras-chave: Lev Tolstói, Tradução, Literatura russa, Não-violência. 


\begin{abstract}
Lev Nikolayevich Tolstoy's vast creative work includes an intense pedagogic activity. From 1858 to 1875 Tolstoy wrote two ABCs and four books of reading for the alphabetization of the Russian people, not only for the pupils of the school of Yasnaya Polyana, but equally for many other schools around the country. Beyond presenting the translation of the Third Book of Reading and exposing some solutions found out during the translation process, this dissertation aims to show how important was this phase in Lev Tolstoy's literary life. Although not much known in Brazil, this phase, in our understanding, is essential for a better comprehension of the literary period the critics use to call the "crisis time" in Tolstoy's life. We add a translation of the letters exchanged between Tolstoy and Gandhi dealing with the non-violence question, an essential one to understand the Tolstoyan literary creative work.
\end{abstract}

Keywords: Lev Tolstoy, Translation, Russian Literature, Nonviolence. 


\section{Краткое содержание}

Обширное творчество Льва Николаевича Толстого включает в себя интенсивную педагогическую работу. За период примерно с 1858 по 1875 год Толстой написал две азбуки и четыре книги для чтения, целью которых было обучение русского народа грамоте, проводившееся на протяжении десятилетий не только в школе в Ясной поляне, но и в других учебных заведениях России. Кроме перевода «Третьей книги для чтения» и представления некоторых решений, найденных в процессе перевода, данная диссертации показывает важность этой еще мало известной бразильскому читателю стороны литературной деятельности Льва Николаевича Толстого. С нашей точки зрения, она является существенной для понимания произведений писателя, написанных в период, который большинство критиков традиционно называет «кризисным». Мы также решили добавить перевод переписки между Л.Н.Толстым и Махатмой Ганди, так как считаем, что в ней в более явной форме, чем в других текстах, обсуждается вопрос ненасилия, который, в свою очередь, важен для понимания литературного творчества Толстого, включающего педагогические произведения.

Ключевые слова: Л. Толстой, Перевод, Русская литература, Ненасилие. 


\section{Sumário}

Notas preliminares

10

Introdução

\section{$\underline{\text { Capítulo I }}$}

Estrutura das Cartilhas e dos Livros de Leitura

Capítulo II

Terceiro Livro de Leitura - tradução

\section{Capítulo III}

Observações gerais sobre a tradução do Terceiro Livro de Leitura..... 154

Tempos verbais em "O mujique e os pepinos", de Lev N. Tolstói

\section{Capítulo IV}

"Vida de um soldado" 198

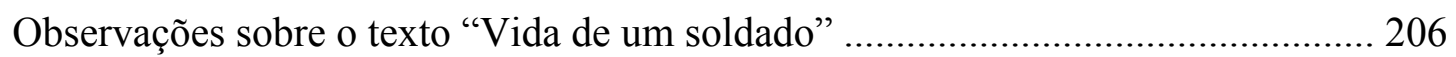

Recordações de um aluno da escola de Iásnaia Poliana - tradução ......................... 208

- Algumas observações sobre a tradução desse texto ............................................ 217

Correspondência entre Lev N. Tolstói e Mohandas K. Gandhi - tradução ............. 219

Lev N. Tolstói e Mohandas K. Gandhi ................................................................... 240

\section{Conclusão}

Tolstói e o mundo camponês

Bibliografia

Apêndice

I - "Aliocha, o Pote" - tradução 261

II - "Com Tolstói, em Iásnaia Poliana" - tradução 


\section{Notas preliminares}

Meu primeiro contato com a obra pedagógica de Lev N. Tolstói, especialmente seus quatro Livros de Leitura, deu-se no início desta década, pela tradução de Charles Salomon, feita do russo para o francês.

Após rápida pesquisa, certifiquei-me de que a obra ainda não havia sido traduzida para o português, embora houvesse uma breve seleção dos textos dos Livros de Leitura, editada em Portugal por José Aguilar, em uma coleção dita "Obra Completa de Leão Tolstói", mas que totaliza apenas três volumes.

Em meu entender, era absolutamente necessário que esses livros fossem integralmente traduzidos para o português e publicados no Brasil. Os leitores brasileiros tinham o direito de conhecer também a produção literária de Tolstói dessa época.

O Primeiro Livro de Leitura foi, então, organizado por mim, traduzido por M. Aparecida B. P. Soares, prefaciado pela $\operatorname{Prof}^{a} \operatorname{Dr}^{\mathrm{a}}$ Aurora F. Bernardini, e ilustrado com desenhos feitos por Tolstói durante o período em que ele se dedicou às Cartilhas, aos Livros de Leitura, à escola de Iásnaia Poliana e a atividades pedagógicas de modo geral. Este livro foi publicado em 2005, por Ateliê Editorial, com o título de Contos da Nova Cartilha - Primeiro Livro de Leitura.

O Segundo Livro de Leitura, ainda no prelo, foi traduzido em co-autoria com a Prof $^{\mathrm{a}} \operatorname{Dr}^{\mathrm{a}}$ Aurora F. Bernardini. Será também publicado por Ateliê Editorial, e contará com ilustrações, especialmente feitas para essa edição em língua portuguesa, por alunos de uma escola russa da cidade de Ijevsk.

O Terceiro Livro de Leitura, objeto principal desta Dissertação, dá sequência às outras duas traduções. Também tenho a intenção de traduzir o Quarto Livro de Leitura, último da série idealizada por Tolstói; assim, o ciclo das obras que o escritor escreveu para o público infantil estará concluído também em língua portuguesa.

Fazem parte dos escritos dessa época uma série de adivinhas, traduzidas e publicadas no Primeiro Livro de Leitura; alguns provérbios, que acompanharão a publicação do Segundo Livro de Leitura; e breves contos baseados em provérbios que, por sua vez, acompanharão o Terceiro Livro de Leitura quando de sua publicação. 
Creio ser importante dizer que este trabalho é um ponto de partida para um estudo mais aprofundado da fase da vida de Tolstói em que ele se interessou mais profundamente pela literatura infantil e pela literatura escrita para o povo; com isso, quero também - e sobretudo - dizer que apenas esta fase literária do escritor foi aqui estudada.

Considero parte principal do trabalho a tradução do Terceiro Livro de Leitura, no entanto, acrescentei-lhe alguns capítulos, ficando assim estruturado: na "Introdução", tratei basicamente, e de maneira geral, sobre o interesse de Tolstói pela pedagogia; sobre a escola de Iásnaia Poliana; sobre algumas características de sua obra pedagógica e da obra escrita especialmente para o povo; e sobre a relação entre Tolstói e os camponeses.

No primeiro capítulo, intitulado "Estrutura das Cartilhas e dos Livros de Leitura", mostro, com exemplos retirados das próprias Cartilhas (da Cartilha e da Nova Cartilha), o raciocínio pedagógico de Tolstói ao criar métodos de alfabetização e aprendizagem. Dificilmente as Cartilhas serão traduzidas para o português, pois elas se destinam à alfabetização de crianças russas na língua russa; por essa razão, achei que poderia haver interesse em demonstrar como se estruturam ambas as Cartilhas, visto que elas também fazem parte da totalidade da obra do escritor. Em seguida, neste mesmo capítulo, abordo a estrutura dos Livros de Leitura, indico os gêneros e as fontes de cada texto que os compõe e teço alguns comentários sobre a diferença entre as fábulas escritas, ou adaptadas, por Tolstói e as fábulas de Esopo, fabulista que o autor admirava bastante, e cujos textos serviram de base para as suas adaptações.

O segundo capítulo é exclusivamente dedicado à tradução do Terceiro Livro de Leitura.

O terceiro capítulo foi subdividido em duas partes: na primeira, intitulada "Observações gerais sobre a tradução do Terceiro Livro de Leitura", exponho os vários problemas com que me depararei durante o trabalho de tradução, aponto algumas possibilidades de tradução, justifico minhas opções, etc.; na segunda parte, "Tempos verbais em 'O mujique e os pepinos", trato, de maneira mais densa, de uma questão específica: o emprego dos tempos verbais em um texto pertencente ao Primeiro Livro de Leitura.

O quarto capítulo foi dividido em três partes: na primeira, intitulada "Observações sobre o texto "Vida de um soldado", apresento, uma vez mais, o texto "Vida de um soldado", pertencente ao Terceiro Livro de Leitura, bem como alguns 
comentários sobre o mesmo texto. Além de sua qualidade literária, tal texto chamou particularmente a minha atenção por ter sido escrito por Fedka, apelido de Vaska Morózov, um dos alunos da escola de Iásnaia Poliana. Em seguida, neste mesmo capítulo, apresento mais um texto, também escrito por Fedka, agora já adulto e na condição de ex-aluno da escola de Tolstói, e que traduzi da versão francesa de Myriam Fainbaum, pois não localizei o texto integral original em língua russa ${ }^{1}$. Nele, Fedka conta-nos um pouco sobre a época em que frequentou a escola de Iásnaia Poliana, convivendo diariamente com Tolstói e com outros alunos, e fala-nos sobre o texto "Vida de um soldado", por ele escrito na época. Reservei uma parte deste capítulo para a correspondência mantida entre Tolstói e Gandhi, e a última parte para alguns comentários, principalmente sobre essa mesma correspondência. Optei por incluir essas cartas em meu trabalho porque, além de até então inéditas ${ }^{2}$, foram escritas em um período da vida pessoal, espiritual e literário de Tolstói que muito me interessa.

Na conclusão, “Tolstói e o mundo camponês”, trato principalmente da relação entre o escritor e a vida rural russa da época; a meu ver, extremamente importante na vida pessoal e na produção literária de Tolstói.

Por fim, no Apêndice, inclui as traduções de dois textos: "Aliocha, o Pote", de Tolstói, traduzido do russo, e "Com Tolstói, em Iásnaia Poliana", escrito por Paul Boyer, e traduzido do original em língua francesa. "Aliocha, o Pote" é um conto pertencente à literatura escrita para o povo; no segundo texto, temos um relato, feito por Boyer, sobre alguns dias em que esteve hospedado em Iásnaia Poliana e sobre seu convívio com Tolstói durante esse período.

\footnotetext{
${ }^{1}$ Assim como ocorre com o texto em francês de Myriam Fainbaum, a edição (em língua russa) de que disponho das Cartilhas —Л. Н. Толстой. Азбука - Новая Азбука. Москва Просвещение, 1978 apresenta apenas alguns trechos do texto de Vaska Morózov. Contrariamente à versão em língua francesa, da edição em língua russa não constam as partes em que Morózov trata especificamente do texto «Vida de um soldado»; por essa razão, por não dispor do texto completo em língua russa, preferi traduzir a versão francesa, já que, para mim, o mais importante neste capítulo de meu trabalho foi obter informações mais precisas sobre o processo de criação de Tolstói junto a seus alunos.

${ }^{2}$ As cartas foram publicadas apenas em 2008: In Cadernos de Literatura em Tradução, vol. 9. São Paulo: Humanitas FFLCH-USP, 2008, pp. 85-113.
} 


\section{Introdução}

Um mujique, a Tolstói, quando de sua fuga:

"Por que você não vira monge? Salve a sua

alma, meu velho, fique no monastério."

E Tolstói sorri-lhe um sorriso simples e bom.

O interesse de Tolstói pela pedagogia e o seu desejo de eliminar ao menos o analfabetismo entre os camponeses russos levaram-no a alguns anos de dedicação efetiva à atividade de ensinar. Como era seu costume refletir profundamente sobre todo e qualquer assunto que lhe interessasse, registrando tudo - pensamentos e conclusões a que chegava - , depois de fundar uma escola em sua própria casa, em Iásnaia Poliana, editou a "Revista da Escola de Iásnaia Poliana". Com sua habitual seriedade, sinceridade e persistência, Tolstói deixou nela registrados vários artigos pedagógicos, suas experiências como professor, bem como textos importantes e críticos sobre a instrução pública na Rússia da época, além de um projeto longo e minucioso para a organização de escolas populares e uma exposição detalhada sobre o que foi a escola de Iásnaia Poliana entre novembro e dezembro de 1862. Ainda nessa revista, ele relata-nos a maneira como várias disciplinas - leitura, redação, gramática, caligrafia, religião, geografia, desenho, canto, dentre outras - foram oferecidas aos alunos camponeses e por eles recebidas e assimiladas.

Sua dedicação a atividades escolares, ou pedagógicas, costuma ser dividida em dois períodos: o primeiro, de 1858 a 1862, com a interrupção de um ano, 1860, quando viajou para fora da Rússia; o segundo período abrange os anos de 1872 a 1875.

No primeiro período, Tolstói dirige a escola, dá aulas, coloca em prática as ideias que defende, inspeciona escolas vizinhas; em resumo, acumula acertos e erros. Durante o ano de 1862, dedica-se à edição da "Revista da Escola de Iásnaia Poliana", em que podem ser lidos também artigos escritos por professores de escolas próximas à sua, todos eles revisados pelo escritor. Essa época foi essencial para Tolstói comprovar que qualquer técnica pode ser útil, desde que seja produto da experiência pessoal e que seja absorvida de maneira a motivar o aluno.

No segundo período, Tolstói expõe os resultados obtidos no período anterior, e escreve a Cartilha, livro que totaliza 758 páginas e que, durante décadas, foi empregado na alfabetização de crianças de toda a Rússia. Seu sonho - o de que crianças de toda e qualquer condição social aprendessem a ler e a escrever com sua 
Cartilha - fora realizado. Seguindo as instruções do autor, a Cartilha permite aos professores guiar os alunos desde o abecedário até a leitura de textos posteriormente reunidos nos Quatro Livros Russos de Leitura -, cujo grau de dificuldade, assim como a extensão aumentam progressivamente.

Tolstói jamais poupou várias e duras críticas às escolas, à pedagogia e aos pedagogos de sua época, fossem russos ou estrangeiros; para ele, o principal problema estava no fato, incontestável, de que a escola não respondia às questões que a vida colocava, ou seja, havia uma visível e inegável distância entre escola e vida, e, consequentemente, entre as verdadeiras necessidades do povo, ofuscadas pela obrigatória submissão à pessoa e ao poder do professor, e, se quisermos ir um pouco além, igualmente ignoradas pelo Estado. Em outras palavras, Tolstói defendia atividades pedagógicas saudáveis, que unissem os envolvidos - professores, alunos e, por conseguinte, também a sociedade - em torno do saber, da troca de conhecimento entre todos, sem exceção, o que atenuava, inclusive, toda e qualquer hierarquia, pois ele acreditava que todos nós temos o que ensinar a qualquer pessoa, e cada pessoa, seja ela quem for, tem sempre algo a nos ensinar.

Para Tolstói, era igualmente de importância extrema que o aluno desenvolvesse sua capacidade criativa: depois de detectada, essa capacidade deveria ser alimentada constantemente com o que houvesse de melhor nas artes, na natureza, nos livros, nas trocas de ideias e nas inúmeras e variadas conversas e atividades que ele e os outros mestres de Iásnaia Poliana mantinham com os alunos.

É importante destacar que suas ideias podem ser resumidas em uma simples equação: necessidade e/ou desejo de aquisição de conhecimentos de uns + desejo de ensinar de outros $=$ desenvolvimento pessoal de todos. Para tanto, alunos e professores devem ser movidos por forte sentimento de fraternidade.

Também a liberdade é fundamental na pedagogia tolstoiana. Bastante influenciado sobretudo por Rousseau ${ }^{3}$ — não me aprofundarei na relação existente entre o trabalho desses dois escritores e filósofos - Tolstói acreditava que o desenvolvimento natural e pessoal da criança não deveria ser perturbado, ou contaminado, pelo professor. Quaisquer punições tampouco eram admitidas em sua escola, pois, para ele, a inutilidade da violência era evidente, e, seus malefícios, inúmeros.

\footnotetext{
${ }^{3}$ Jean-Jacques Rousseau (1712-1778). Filósofo suíço, escritor, teórico político. Dentre outras, defendia a teoria de que todos os homens nascem livres e, portanto, a liberdade faz parte da natureza humana.
} 
Acredito que, já em sua escola de Iásnaia Poliana, em Guerra e Paz e em várias outras obras, Tolstói tenha feito amplo uso dos princípios que se perpetuariam com o nome de "teoria da não-violência", da não resistência ao mal. A experiência desenvolvida, sobretudo, em Iásnaia Poliana encontra-se formulada nas cartas trocadas entre ele e Gandhi. De acordo com seus relatos registrados nos diversos artigos que compõem a "Revista da Escola de Iásnaia Poliana", é suficiente a não imposição de ordem alguma para que, nos momentos de desordem por parte dos alunos, uma ordem mais sólida imponha-se livremente. Ao nos explicar sobre o que era a sua escola, Tolstói conta-nos que a experiência ensinou-lhe, por exemplo, que quanto mais alto o professor grita, mais alto ainda gritam os alunos, ou seja, rispidez gera rispidez, e violência gera violência.

Em 1862, a polícia invade brutalmente a escola; tudo ali é vasculhado, professores são interrogados, e os manuscritos de Tolstói são lidos. O próprio escritor e sua escola haviam sido vítimas de violência, ninguém se recupera dela, e a escola é fechada.

Em determinado momento de sua vida, Tolstói passa a buscar obstinadamente a simplicidade em tudo: na vida e na arte, sobretudo em sua própria literatura. Aproxima-se, então, não apenas dos camponeses, mas também de alienados $(\text { юродивыц })^{4}$, de andarilhos, e de todo o tipo de pessoas comumente rejeitadas pela sociedade, mas por ele consideradas mestres, atentando para a beleza da linguagem popular russa, que, segundo ele, guarda o verdadeiro espírito da língua russa. Era nessa língua popular que as imagens tinham mais sabor, era nela que a sabedoria legendária ainda pulsava, e, sobretudo, era dela que brotavam elementos espantosamente ainda crus e, por conseguinte, extremamente poéticos, e que ele tanto apreciava.

Acredito que a língua deva, aqui também, ser entendida como um organismo vivo, suscetível a constantes mudanças, sejam elas decorrentes dos mais, ou menos, avançados graus de civilização, de diversas instituições, dos diferentes costumes nacionais e, em cada nação, dos distintos meios sociais e culturais que a empregam e que a consomem, de feitos históricos, políticos, etc. No livro Fundadores da

\footnotetext{
${ }^{4}$ Aos юродивый é atribuído o dom da clarividência. Eles são venerados e/ou considerados sagrados em muitos lugares da Rússia.
} 
Modernidade $^{5}$, a Prof ${ }^{\mathrm{a}}$ Aurora Bernardini cita uma frase de Tchékhov, a propósito de Turguêniev: “As descrições de Turguêniev são bonitas, mas eu sinto que já perdemos o gosto por esse tipo de escritura, é preciso encontrar algo de diferente”. Segundo ela, “essa diferença é a modernidade", manifestada, em Tchékhov, por certa "estratégia de brevidade":

Analisar friamente o real, exacerbá-lo até torná-lo simbólico, decompô-lo e reunir certos elementos privilegiados que 'agarrarão' o leitor. A escolha é o primeiro passo: saber discernir o que é importante e o que não é; saber organizar esta escolha, em segundo lugar, e, finalmente, saber falar a língua de cada personagem. ${ }^{6}$

No capítulo XI de $O$ que é a arte?, Tolstói diz que a arte verdadeira, a arte universal, ou a arte popular, apenas é possível quando o artista é tocado por forte emoção e sente necessidade de transmiti-la a outras pessoas, ao passo que a arte profissional, a arte de conteúdo pobre e de forma obscura, apreciada pelas classes abastadas, surge não de um impulso íntimo do artista, mas do desejo de divertimento que elas almejam, pagando generosamente àqueles que exprimam renovados sentimentos que lhes cheguem de maneira agradável aos sentidos. Tolstói cita quatro métodos que, segundo ele, são empregados por esse segundo grupo de artistas, fazedores de uma arte que se transformou em "simulacro" ou "contrafação". No primeiro método estão os "empréstimos", a saber, a reutilização de elementos de obras anteriores, como temas e demais elementos já reconhecidamente poéticos que, após serem retrabalhados até ganharem certa aparência de novos e, graças à "fonte" que lhes serviu de "inspiração", produzem, em pessoas pouco exigentes, ou de gosto estético pervertido, certo efeito de arte que, por sua vez, é doadora de nada além de prazer momentâneo:

Mas a impressão artística, vale dizer, o contágio da emoção, só se obtém quando o autor transmite um sentimento que ele mesmo experimentou, à sua maneira, e não um sentimento que outro experimentou e lhe transmitiu. ${ }^{7}$

\footnotetext{
${ }^{5}$ BERNARDINI, Aurora F. A Modernidade na Literatura Russa. In: Fundadores da Modernidade. I. Chiampi (org.). São Paulo: Editora Ática, 1991, p. 159-182.

${ }^{6}$ Ibidem, p 160.

${ }^{7}$ TOLSTÓI, L. N. O que é a arte? (Trad. Aurora F. Bernardini). In: Fundadores da Modernidade. I. Chiampi (org.). São Paulo: Editora Ática, 1991, p. 172.
} 
Cabe lembrar que, sobretudo quando escrevia a sua chamada "literatura para o povo", Tolstói estava já bastante próximo do mundo rural, observando a maneira como a língua era empregada pelos camponeses, fazendo anotações, refletindo sobre como os sentimentos, as aspirações, o raciocínio, etc., refletiam-se na expressão verbal do povo que habitava a zona rural russa, chegando a arar a terra, plantar, colher, fabricar e consertar sapatos, arrumar o seu próprio quarto, dispensando, assim, a ajuda de empregados, chegando, também, a participar de reuniões que se davam no meio rural; em uma palavra, na medida do possível, viver, de fato, no mundo e entre as pessoas sobre que e sobre quem ele escrevia, ou seja, mergulhado em temas e demais elementos que passavam a fazer parte de sua arte literária.

Do segundo método, consta a "imitação"; de acordo com Tolstói, é ela que faz parecer arte o que não é arte, servindo-se, para tanto, de descrições extremamente detalhadas. Certos tipos de arte, como a literária, a dramática e a pictórica, por exemplo, tentam se aproximar de um realismo extremo que, para se concretizar, apóia-se na exposição de inúmeros - e desnecessários — detalhes que, por sua vez, acompanham o objeto descrito.

O terceiro método é chamado de "surpresa", ou "efeito", e consiste na maneira como a "obra de arte" age sobre a sensibilidade de quem a experimenta. Usam-se efeitos de contraste - belo/feio; barulho/silêncio; etc. — e, especialmente na arte literária, empregam-se também detalhes que despertam os mais variados sentimentos, como o horror, além de inúmeros outros "estados de espírito".

O quarto método é o "interesse" que se tenta suscitar no público; assim, o leitor interessado em determinado assunto confundirá o seu próprio interesse com uma possível impressão artística que ele venha a ter da obra. Para que esse quarto método seja praticado, empregam-se, sobretudo, descrições e informações calcadas em documentos; no entanto, são igualmente empregados determinados meios de expressão, o que funciona aos moldes das charadas, visto que tal procedimento leva o público a desejar adivinhar o "sentido" ou, em termos mais atuais, a "mensagem" de determinada obra, e, consequentemente, ter a impressão de haver recebido alguma coisa proporcionada pela obra de arte.

Finalmente, para Tolstói, as principais qualidades de uma obra de arte verdadeira devem ser, além, obviamente, da originalidade — talvez seja possível acrescentar a "sinceridade", que deve estar sempre intimamente unida à “originalidade" —, a coesão, a organicidade e a harmonia, ou fusão, entre forma e 
conteúdo, que servem, justamente, para expressar o sentimento inicial e propulsor, experimentado pelo criador da obra; dessa maneira, seguramente, o próprio interesse experimentado pelo artista contagiará, de fato, o público.

Concluo que, aos olhos de Tolstói, ao se expressar em sua linguagem, o camponês não tinha esses vícios. Seus relatos continham ideias claras, raciocínios descomplicados, e tampouco havia palavras em excesso, que, agrupadas ou dispersas, pouco diziam. Neles, imperava, de maneira natural, uma ordem simples e despoluída, maneira de se expressar que era própria do homem do campo; assim, percebendo-a, estudando-a, aprendendo-a e vivenciando-a profundamente, Tolstói incorporou-a à literatura que produziu, literatura simples, natural, livre de parasitas. Encontra, então, aquele "algo diferente" a que se referia Tchékhov, e, no final do século XIX, mais precisamente em 1884, escreve, dentre vários outros exemplos que poderiam ser citados, "Memórias de um louco", em que aproxima, une, e associa o, até esse momento, surpreendente, criando o novo, o inesperável, o original, o moderno. Em determinado trecho do texto, o protagonista - o próprio Tolstói - descreve seu desespero por não conseguir dormir, bem como o instante em que foi, justamente por essa razão, invadido por "um terror vermelho, branco e quadrado". Uma possível falta de data e assinatura poderia facilmente nos levar a atribuir tal frase a algum texto psicológico de nossa época, como, por exemplo, os de Clarice Lispector, embora toda a literatura do século XX deva muito a Tolstói e às suas descobertas artísticas.

Finalizando, Tolstói percebe que, além de rica, a língua falada por aquela gente simples servia-lhe, a ele, como uma espécie de contenção, pois ela tinha um "esqueleto" que lhe impedia ser livremente modelada, não permitindo ao escritor ênfases em demasia; em outras palavras, ela não suportava excessos desnecessários, característica comumente presente em literatura de má qualidade. Ainda de acordo com ele, por não ter nenhum esqueleto, a língua literária "culta" podia ser trabalhada como um bloco de massa, de qualquer maneira, e, como resultado, tudo parecia ser literatura, o que não passava de um grave engano. Em várias ocasiões, Tolstói escreveu histórias em conjunto com alguns alunos de sua escola; em outras, sugeriu um tema aos alunos e pediu-lhes que escrevessem histórias que, mais tarde, eram revistas e polidas por ele; em outras, ainda, corrigia relatos feitos por algum camponês e anotados por algum membro de sua família. 
Assim, vivendo no campo e entre os camponeses, ia, dia após dia, descobrindo a beleza da língua popular, bem como as possibilidades que ela oferecia, e aprendendo expressões e um vocabulário que, até então, ignorava.

O convívio com os camponeses e o seu amor por eles, por seus costumes e hábitos, por sua maneira de raciocinar e de empregar a língua, fizeram mais do que influenciar o estilo do já consagrado escritor, passaram também a lhe inspirar vários contos, os chamados "contos para o povo". Neles, assim como nos textos dos Quatro Livros Russos de Leitura, a linguagem e o estilo presentes em obras como Guerra e Paz e Anna Karênina - notadamente os períodos compostos de orações subordinadas bastante complexas e requintadas — desaparecem e surgem uma linguagem e um estilo simples, livres de quaisquer modismos linguísticos ou literários, e desprovidos de qualquer tipo de rebuscamento, mas, a exemplo dessas duas grandes obras, ainda impregnados da genialidade do escritor. São, portanto, jóias confeccionadas com um material que se encontra em outro estado, mas pelo mesmo talentoso ourives, fato ainda negado por vários estudiosos de sua obra, inclusive russos. Para admirar Tolstói também nesta fase literária, é preciso reconhecer, como disse certa vez Rodin, o anjo que existe na pedra bruta.

Assim como desejava que sua Cartilha guiasse o aprendizado de qualquer criança russa, pertencesse ela à nobreza ou ao mais miserável campesinato, também em seus contos para o povo Tolstói almejava uma arte ao alcance de todos, uma arte que contivesse valores e sentimentos eternos, como o amor entre os homens, e que fosse desprovida de qualquer componente perecível, como modismos literários e sociais, dentre outros.

Tolstói admirava o talento que o camponês tinha para contar histórias. Além da linguagem tipicamente rural, havia em seus relatos sobretudo simplicidade, e nada além do estritamente necessário, combinação que resultava em arte de excelente qualidade, na arte que ele tanto considerava. 
CAPÍTULO I 


\section{Capítulo I}

O aluno nada traz [para a escola] além de si mesmo: sua natureza impressionável e a certeza de que a escola será tão agradável quanto o fora ontem.

\section{Estrutura das Cartilhas e dos quatro Livros de Leitura}

\section{Cartilha $^{8}$}

Em um período de cerca de três anos, Tolstói escreveu duas cartilhas: a primeira, denominada simplesmente Cartilha, em 1872, e a segunda, Nova Cartilha, em 1874-1875. ${ }^{9}$ De acordo com a edição de que disponho ${ }^{10}$, a está composta da seguinte maneira:

O primeiro capítulo inicia-se com o alfabeto; trata-se de uma introdução, conforme ordem estabelecida por Tolstói. ${ }^{11} \mathrm{Na}$ primeira parte, cada letra do alfabeto - agora apresentada também nas formas maiúscula e minúscula, tipográfica e cursiva - está associada a um desenho, cujo nome do objeto que ele representa tem como primeira letra a letra representada isoladamente, ou seja, o método é o mesmo de uma cartilha clássica usada, durante décadas, também entre nós:

$A, a ; E, \sigma ; B, 6$; etc.

\footnotetext{
8 Л. Н. Толстой. Азбука. С.-Петербургь. Тип. Замысловскаго, Больш. Мящан., ‥ 33. 1872.

${ }^{9}$ Não tive acesso a nenhum estudo que se dedicasse realmente a expor e a discutir as diferenças existentes entre essas duas cartilhas. Por motivos óbvios, supus que, seguramente, a Cartilha, ou a primeira cartilha escrita por Tolstói, não cumpriu as suas exigências de professor e de pedagogo. Comparar as duas cartilhas, e tentar mostrar as diferenças entre o plano geral, o conteúdo e a estrutura lógica de ambas afastar-me-ia do objetivo deste trabalho. No entanto, Semion F. Egorov*, especialista em história da educação, esclarece, por exemplo, que, na época em que Tolstói empregava a sua Cartilha na alfrabetização de crianças, o método fonético de alfabetização era priorizado em relação ao método ortográfico, e que, para Tolstói, ambos os métodos eram complementares, pois, segundo ele, negar que o método fonético contenha elementos gráficos era ignorar uma experiência pedagógica secular. Segundo Egorov, o caráter inovador da Cartilha não foi imediatamente compreendido nem apreciado, ao contrário, suscitou várias polêmicas, e, graças também a elas, Tolstói pôde melhorar bastante a sua Nova Cartilha, que foi favoravelmente recebida pela imprensa, por revistas especializadas em pedagogia e, finalmente, adotada pelo Ministéiro da Educação da Rússia. * In: EGOROV, Semion F. Tolstóï Pédagogue. L'Encyclopédie de l’Agora, Disponível em: < http://agora.qc.ca/ >. Acesso em 19 de maio de 2009.
}

10 Л. Н. Толстой. Азбука - Новая Азбука. Москва. Просвещение, 1978.

${ }^{11}$ Ibidem, p. 30 e 31. 
E os desenhos que a elas correspondem são, de acordo com o exemplo que escolhi:

uma melancia, арбуз; um barril, бочка; um garfo, вилка. ${ }^{12}$

$\mathrm{Na}$ segunda parte do capítulo, há um conjunto criado para o aprendizado de uma leitura silábica:

- O primeiro deles, composto por duas letras:

Ба, Чa, Гa, etc. $^{13}$

- O segundo, por três letras:

Бла, Нла, Мла, etc. ${ }^{14}$

- O quarto também apresenta grupos de três letras:

Cъ $a$, Cна, Cка, etc. ${ }^{15}$

- O quinto, composto apenas de três linhas, acrescenta exemplos formados por quatro letras:

Бска, Вздbl, Вдру, etc. ${ }^{16}$

- No grupo seguinte, os conjuntos fonéticos são maiores:

Бстро, Бздна, Вздра, etc. ${ }^{17}$

- A seguir, a letras isoladas, ou a grupo de letras, são acrescidos sinais fonéticos como o miákhki znak (мягкий знак - в - ) е о tviórdy znak (твёрдый знак - в -):

$B b, B b, H b$, etc.

$5 b, B b, H b$, etc. ${ }^{18}$

- O último conjunto traz grupos de três letras, em geral com significado, ou seja, pequenas palavras, de uma única sílaba:

Дай, Чaй, Сaй, etc. ${ }^{19}$

Дай: segunda pessoa do singular do imperativo do verbo damb: «dar»

Чaŭ: «chá»

Caŭ: sem significado específico

$\mathrm{Na}$ terceira parte, há treze pequenos grupos de palavras, divididas em sílabas $^{20}$ :

\footnotetext{
${ }^{12}$ Ibidem, p. 33.

${ }^{13}$ Ibidem, p. 43.

${ }^{14}$ Ibidem, p. 43.

${ }^{15}$ Ibidem, p. 44.

${ }^{16}$ Ibidem, p. 44.

${ }^{17}$ Ibidem, p. 44.

${ }^{18}$ Ibidem, p. 45

${ }^{19}$ Ibidem, p. 45.

${ }^{20}$ Ibidem, p. 46 e 47.
} 
1) Шу-ба; Ру-ка; Лю-ди; еtс.

Шуба: «casaco de pele»

Рука: «braço, mão»

Люди: «homens, gente»

2) Tpa-ва; Cmy-чu; Kpbl-ca; etc.

Tрава: «relva, capim»

Стучи: segunda pessoa singular do imperativo do verbo стучать: «bater»

Kpысca: «ratazana»

3) He-бo; Mo-pe; Пe-po; etc.

Небо: «céu»

Mope: «mar»

Перо: «pluma»

4) Стра-ино; Скла-дьг; Вздро-гну; еtс.

Страшно: advérbio: «extremamente, terrivelmente»

Склады: plural de склад: «depósito, armazém; sílaba; compleição, constituição»

Вздрогну: «sobressalto», do verbo вздрогнуть

5) Бу-ма-га; Ста-ру-ха; Ка-рти-на; еtс.

Бумага: «рареl»

Cmapyxa: «velha»

Картина: «quadro, tela»

6) Я-ма; И-скра; И-зба; еtс.

Ямa: «cova, buraco»

Искра: «faísca»

Изба: «isbá»

7) Во-е-во-да; За-и-ка; На-у-ка; еtс.

Воевода: «voievoda», chefe militar e governador de província na Rússia dos séculos XVI-XVIII Заика: «gago»

Наука: «ciência»

8) Э-то; Э-то- $m ъ$; Э-то-мy; еtc.

Эmo: pronome demonstrativo: «isto, isso»

Этотъ: pronome demonstrativo «este, esse»

Этому: dativo de Это

9) $\mathrm{Po-mъ}$; Ko-mъ; Ho-cъ; etc.

Ротъ: «boca»

Komъ: «gato»

Hocъ: «nariz»

10) Ду-рной; Хо-ро-щій; Стой; etc.

Дурной: «ruim»

Хорошій: «bom» 
Стой: segunda pessoa do imperativo do verbo стоять: «parar»

11) Зе-лё-ныци; Ве-сё-льіи; Пё-стрый; etc.

Зелёный: «verde»

Весёльій: «alegre»

Пёстрый: «multicolor, estampado»

12) Жу-жжа-ть; Вва-ли-ли; Стра-нно; etc.

Жужжать: «zumbir»

Ввалили: terceira pessoa do plural do pretérito perfeito do verbo ввалить: «invadir»

Странно: advérbio: «estranhamente, singularmente»

13) Бой-ка-я; Ме-нь-иой; Най-де-мъ; etc.

Бойкая: «vivaz»

Меньшой: «menor»

Найдемъ: terceira pessoa do plural do futuro simples do verbo найти: «encontrar»

Em seguida, em uma subdivisão ainda da terceira parte, a cada letra do alfabeto - maiúsculas e minúsculas - corresponde um ou mais provérbios e/ou pensamentos, cuidadosamente escolhidos para ilustrar a ocorrência, nas palavras que os compõem, da letra em questão, ou seja, da letra que se quer ensinar ${ }^{21}$ :

$a$.

На-ии пря-ли, а ва-ии спа-ли.

Em uma tradução literal: «Os nossos tecem, e os seus estão dormindo», ou «Uns dormem, outros trabalham»

$\sigma$.

Ба-бу-шк 22 то-ль-ко д -ду-ика не вну-къ

Em uma tradução literal: «Para a vovó apenas o vovô não é neto».

$e$.

Не ве-ли-кь све-рчо-кь, да сль-ино кри-чи-ть.

Em uma tradução literal: «O grilo é pequeno, mas o seu grito é alto», ou «Tamanho não é documento»

Depois, há uma interrupção na sequência; agora, o alfabeto está agrupado em

letras cursivas, maiúsculas e minúsculas. Tolstói prossegue com grupos de frases que apresentam iniciais maiúsculas e minúsculas, e, cada grupo é, então, dividido em dois blocos: o primeiro trabalha a letra em suas formas maiúscula, tipográfica e cursiva ${ }^{23}$ :

A. A.

А-збу-ку $\quad$-ча-ть, навсю и-збу кри-ча-ть.

\footnotetext{
${ }^{21}$ Ibidem, p. 47.

22 «Яmb», letra do alfabeto eslavo-eclesiástico; foneticamente, esta letra é assim transcrita: [æ]

${ }^{23}$ Ibidem, p. 48.
} 
Em uma tradução literal: «Estudam a cartilha, e gritam por toda a isbá».

a.

Се-мей-на-я ка-ика гу-щуе ки-пи-ть, etc., até a última letra do alfabeto.

Em uma tradução literal: «Mingauzinho feito em casa fica mais consistente».

O segundo bloco apresenta dificuldades maiores de pronúncia, como a que encontramos entre a letra $o$, tônica, com som de [o], e a letra $o$ átona, cujo som é [a]. Tolstói aponta também as diferenças entre $\sigma$ e $n$, entre 3 e $c$, entre 6 e $\phi$, etc. Para tanto, utiliza-se de frases, ditados, provérbios e textos um pouco mais longos. Quando da ocorrência da distinção de sons entre os dois fonemas estudados, a pronúncia correta é indicada sobre a letra da palavra que pode apresentar alguma dificuldade de pronúncia ${ }^{24}$ :

$\underline{O_{B b} A}$

a

ВорО $\boldsymbol{O}^{25}$ соколомь не быть.

Em uma tradução literal: «A gralha não se torna falcão».

ВОронъ в Орону глаза не выклюнеть.

Em uma tradução literal: «Um corvo não pica o olho de outro corvo».

$\begin{array}{llllll}\text { a } & \text { a } & \text { e } & \text { a }\end{array}$

Воровъ въл суловили, а они въ дом были. ВОръ, что заяцъъ-и $m$ ни своей

Em uma tradução literal: «Procuraram os ladrões na floresta, mas eles estavam em casa».

a ц а

боится.

E: «O ladrão é como o coelho: tem medo da própria sombra».

Para terminar, o autor escolhe algumas adivinhas cuja pronúncia apresenta o mesmo problema trabalhado anteriormente ${ }^{26}$ :

a

На двор горой, авъ изб водой. (Сн гъ).

Em uma tradução literal: «No quintal é como uma montanha, e na isbá é como água. (Neve)», ou: «No pátio, aos montes; na isbá, aos baldes» (A neve $)^{27}$

b

a

a

Лежить - ниже кота, встанеть - выше коня. (Дуга).

Em uma tradução literal: «Deitado é mais baixo do que o gato - em pé, é mais alto do que o cavalo» (Arco da carroça)», ou «Deitado, é mais baixo que um gato; em pé, é mais alto que um pangaré» (O arco da carroça $)^{28}$

\footnotetext{
${ }^{24}$ Ibidem, p. 59.

${ }^{25}$ Em caixa maior e negrito no original. Observação válida para as outras ocorrências.

${ }^{26}$ Ibidem, p. 60.

${ }^{27}$ In: TOLSTÓI, Lev. Contos da Nova Cartilha - Primeiro Livro de Leitura. (Trad. M. Aparecida B. P. Soares). Cotia, São Paulo: Ateliê Editorial, 2005, p.174.
} 
Идёть л сомъ - не треснетъ, идёть плёсомъ - не плеснетъ. (М сяиъ).

Em uma tradução literal: «Quando vai pela floresta, não crepita, quando vai pela água não chapinha», ou «Passa pelo bosque sem se arranhar; passa pela água sem marulhar» (A lua) ${ }^{29}$

Assim, temos vários grupos de fonemas, alguns deles já apresentados; agora, no entanto, com desdobramentos das dificuldades de pronúnica. Dos exemplos escolhidos por Tolstói, constam igualmente outras dificuldades, apresentadas por novos, e mais complexos, grupos fonéticos ${ }^{30}$ :

ц $\mathrm{a} \quad \mathrm{a}$

Люди над ются до самой смерти.

Em uma tradução literal: «As pessoas têm esperança até a última hora», ou «A esperança é a última que morre»

Бабы въ пол с ють,

На Бога ся (себя) над ютъ.

Em uma tradução literal: «No campo, as mulheres semeiam; em Deus, elas têm esperança».

$$
\text { a ц а }
$$

\section{Волки и злые люди ходять и озираются.}

Em uma tradução literal: «Lobos e pessoas más andam e olham para os lados».

Dessa forma, Tolstói encerra o primeiro capítulo de sua Cartilha.

O segundo capítulo divide-se em quatro partes, sendo que, na primeira, constam algumas fábulas ${ }^{31}$.

Da segunda, constam textos de gêneros diversos, como descrições, histórias verdadeiras, contos, etc ${ }^{32}$; nela, Tolstói apresenta também sinais de pontuação. $\mathrm{O}$ primeiro texto ${ }^{33}$, «O mar»-Mope -, traz apenas pontos finais, bastante volumosos e em negrito. No segundo ${ }^{34}$, «O cego e o surdo»-Слепой и глухой-, constam pontos finais, igualmente realçados, e outros sinais de pontuação, como dois pontos, vírgulas, travessões e aspas, estes, no entanto, sem nenhum destaque. Do lado esquerdo do título do terceiro texto ${ }^{35}$, «O enjeitado»-Подкидыци -, mas isolado dele, vemos dois pontos «:» em negrito, sendo que esse sinal gráfico se repete várias vezes, tanto no

\footnotetext{
${ }^{28}$ Ibidem, p. 180.

${ }^{29}$ Ibidem, p. 174.

${ }^{30}$ Ibidem, p. 74.

${ }^{31}$ Ibidem, p. 88 a 99.

${ }^{32}$ Ibidem, p. 100 a 118.

${ }^{33}$ Ibidem, p. 100.

${ }^{34}$ Ibidem, p. 100 e 101.

${ }^{35}$ Ibidem, p. 101.
} 
terceiro como no quarto texto ${ }^{36}$, «A pedra»-Камень. A exemplo do terceiro, também o quinto texto ${ }^{37}$, «A tia conta como aprendeu a costurar»-Как меня выуучили иить -, traz o ponto e vírgula; o mesmo processo é adotado tanto nele como no texto seguinte, e há sempre um par de textos depois de cada novo sinal gráfico apresentado. Em seguida, obedecendo ao mesmo processo, Tolstói introduz a vírgula, as aspas, os parênteses, o ponto de exclamação e, finalmente, o ponto de interrogação. O texto «Lipúniuchka» - Липунюшка $a^{38}$ - conclui esta parte . É preciso observar que, também em extensão, os textos aumentam.

A terceira parte ${ }^{39}$ também traz textos variados, de gêneros igualmente variados, com predominância de «histórias verdadeiras», como é o caso de «O elefante» - Слонъ ${ }^{40}$, «Da velocidade vem a força» - Отъ скорости сила ${ }^{41}$, dentre outras.

A quarta parte ${ }^{42}$ compõe-se de um longo poema versificado, intitulado Дурень, ou «O tolo»; a ele, segue-se uma bylina ${ }^{43}$, Святогорь Богатырь, ou «Bogatir Sviatagor».

Finalmente, Tolstói oferece um manual de instruções para os professores ${ }^{44}$.

\section{$\underline{\text { Nova Cartilha }}^{45}$}

A Nova Cartilha inicia-se com o alfabeto antigo, simples, em letras tipográficas ${ }^{46}$. Em seguida, vem o alfabeto, em letras maiúsculas e minúsculas, o

\footnotetext{
${ }^{36}$ Ibidem, p. 102 e 103.

${ }^{37}$ Ibidem, p. 103 e 104.

${ }^{38}$ Ibidem, p. 116 a 118.

${ }^{39}$ Ibidem, p. 119 a 126.

${ }^{40}$ Ibidem, p. 119.

${ }^{41}$ Ibidem, p. 124.

${ }^{42}$ Ibidem, p. 127 a 132.

43 Ibidem, p. 131.

${ }^{44}$ Ibidem, p. 133 a 147.

45 Л.Н. Толстой. Новая Азбука. Москва: Типография и Литография А Тоглецкаго и М Терехова. Кузнецкий Мостъ. Дом Торлецкаго, 1875.

${ }^{46}$ Ibidem, p. 153.
} 
nome da letra e o seu som ${ }^{47}$. Depois, um quadro com o alfabeto em letras cursivas, maiúsculas e minúsculas ${ }^{48}$.

Aа Бб Bв, etc.

$\mathrm{Na}$ sequência, há uma lista de palavras iniciadas com cada letra do alfabeto, em sua ordem conhecida ${ }^{49}$, em um quadro intitulado Слова, начинающіяся съ буквъ Азбуки, ou «Palavras que começam com as letras do alfabeto»:

Аня Баня Ваня, etc.

Аня: diminutivo de «Anna»

Баня: «banheiro»

Ваня: diminutivo de «Ivan»

Há um segundo quadro - Слова, заключающія вс звуки, ou «Palavras compostas por todos os sons»:

Бусы Возы Гущча, etc.

Бусы: «colar de contas»

Bозы: plural de воз: «carroça»

Гущุa: «borra»

E um terceiro quadro - Слова, начинающіяся съ буквъ какъ он произносятся, ou «Palavras iniciadas com letras tal como são pronunciadas»:

Арбузъ. Б лка. Ведро. Etc.

Арбузъ: «melancia»

Б лка: «esquilo»

Ведро: «balde»

Segue uma extensa lista de palavras isoladas e variadas, distribuídas em colunas $^{50}$ :

Туча. Тула. Куча. Etc.

Tуча: «nuvem»

Тула: «Tula, nome de cidade»

Kyчa: «monte, grande porção»

A partir desse ponto, as dificuldades aumentam progressivamente ${ }^{51}$ :

Люди рады. Мама дома. Etс.

Люди рады: «Pessoas contentes»

Маша дома: «Macha está em casa»

Люди пили вино. Маша била Васю. Еtс.

\footnotetext{
${ }^{47}$ Ibidem, p. 154.

${ }^{48}$ Ibidem, p. 155

${ }^{49}$ Ibidem, p. 155.

${ }^{50}$ Ibidem, p. 156.

${ }^{51}$ Ibidem, p. 157.
} 
Люди пили вино: «As pessoas bebiam vinho»

Маша била Васю: «Macha bateu em Vássia»

Em seguida, há um quadro com sujeito e verbo, juntamente com palavras substantivos e verbos - isoladas ${ }^{52}$ :

Я лаю. Я жую. Я рою. Еtс.

Я лаю: «Eu ladro»

Я жую: «Eu mastigo»

Я рою: «Еu cavo»

Уха. Ужи. Уши. Еtс.

Уxa: «sopa de peixe»

Ужи: pequena cobra d'água

Уwu: plural de yxo: «orelha»

Abaixo, a mesma página contém outro quadro, com sujeito, verbo e complemento:

Я лаю на вора. Руби эти ели. Ему надо чаю. Еtс.

Я лаю на вора: «Eu ladro para o ladrão»

Руби эти ели: «Corte esses pinheiros (com machado)»

Ему надо чаю: «Ele precisa de chá»

Seguem-se mais quadros com exemplos de fonemas ${ }^{53}$ :

БЕ. Ве. ГЕ. Де. ЖЕ. Зе. Еtc.

Exemplos de palavras:

Небо. Поле. Море. Еtc.

Небо: «се́u»

Поле: «сатро»

Mope: «mar»

Exemplos de períodos curtos:

Лежу дома. Щели мальы. Перо тупо. Еtс.

Лежу дома: «Estou deitado em casa»

Щели маль:: «Frestas pequenas»

Перо myno: «A pena está sem ponta»

Exemplos de períodos mais longos:

Тётя била Петю. Жили мыши у печи. Баба дала Ван и Пет мёду. Еtс.

Тётя била Петю: «Titia bateu em Pétia»

Жили мыши у печи: «Os ratinhos viviam ao lado do fogão»

Баба дала Ван и Пет мёду: «Vovó deu mel a Vânia e Pétia»

Exemplos de textos breves ${ }^{54}$ :

${ }_{52}^{52}$ Ibidem, p. 158.

${ }^{53}$ Ibidem, p. 159. 
Кат дали мыла.

Она мыла лицё $\ddot{~}^{55}$ и шею.

И лицё и шея и руки Кати были б лы.

Кат дали мылла: «Deram sabão à Kátia»

Она мылла лицё и шею.: «Ela lavava o rosto e o pescoço»

И лицё и шея и руки Кати были б лы.: «Е о rosto, o pescoço e as mãos de Kátia ficaram brancos»

Ainda separados por quadros, Tolstói apresenta mais palavras e mais períodos curtos, seguidos de textos breves e de textos mais longos, alternadamente:

Рыбамъ море, птицамъ воздухъ, людямъ земля.

Рыбамъ море, птицамъ воздухъ, людямъ земля.: «Peixes no mar, passarinhos no céu, gente na terra» além de provérbios, ou simples períodos, misturando-se a palavras soltas, pequenos textos, etc., em um ritmo progressivo de dificuldade ${ }^{56}$ :

Куда иголка, туда и нитка.

Куда иголка, туда и нитка.: Em uma traduçãoliteral: «Para onde vai a agulha, o fio também vai».

Observamos que, de maneira geral, os mesmos provérbios são apresentados duas vezes seguidas: uma em letra tipográfica e outra em letra cursiva.

Sem nenhuma separação rígida, há um texto com indicação de título Красная Шапочка, ou «Chapeuzinho Vermelho» - inserido à maneira dos grupos de fonemas, das frases, dos provérbios, e de outros textos sem qualquer indicação de título $^{57}$. O conto termina, e é seguido por novos grupos de palavras, frases, pequenos textos - pertencentes aos Livros de Leitura - em que os fonemas propostos são empregados; o mesmo procedimento repete-se mais algumas vezes, mais precisamente, até a página 216 de nossa edição.

Na página 216, há mais um texto com indicação de título: Mamb $и$ дочь eя ${ }^{58}$ Анночка. A exemplo do que ocorre depois de «Chapeuzinho Vermelho», temos palavras, frases, etc., até a página 219; dessa página em diante, até praticamente o final da cartilha, há um grande volume de textos, muitos deles sem título e sem indicação de gênero, e somente nos últimos encontramos títulos, e os gêneros indicados. Percebem-se também nessa sequência, grupos de provérbios a que se juntam mais textos; depois do último texto ${ }^{59}$, Филипок, ou «Filipok» -

\footnotetext{
${ }^{54}$ Ibidem, p. 163.

55 Assim no original.

${ }^{56}$ Ibidem, p. 164 a 199.

${ }^{57}$ Ibidem, p. 199.

${ }^{58}$ Assim no original.

${ }^{59}$ Ibidem, p. 234.
} 
curiosamente classificado como «história verdadeira», ou быль —, Tolstói apresenta o alfabeto eslavo $^{60}$, e, para finalizar, duas páginas com instruções aos professores ${ }^{61}$.

Pude verificar que os provérbios têm importância considerável na obra de Tolstói, sobretudo em sua obra didática, bem como no conjunto dos textos escritos para o povo; também em seu Calendário ${ }^{62}$, provérbios e citações «extraídos» das mais variadas fontes formam a quase totalidade da obra. Um pouco como os haikais japoneses, os provérbios circulam pela arte da brevidade, concentrando, em poucas palavras, princípios, ensinamentos de conduta, tiradas humorísticas, sentimentos de pesar, dúvidas sobre mistérios, sobre o efêmero das coisas em geral, da natureza, da existência.

De acordo com o professor Serguei Neklíudov ${ }^{63}$, a invenção da escrita dividiu a humanidade em duas partes: uma, escrita; outra, oral. E toda cultura escrita tem, obrigatoriamente, um componente oral que é refletido no folclore, de que fazem parte os provérbios, que se prestam muito bem a fins pedagógicos, graças a vários possíveis elementos de sua própria estrutura, como a rima - que dá cadência e facilita a memorização —, a repetição e/ou a oposição de palavras, vários tipos de paralelismos — sejam eles fônicos, morfossintéticos, etc. — e, em muitos casos, estrutura sintática binária, concisão, brevidade, dentre outros.

Às vezes bastante claros, diretos e explícitos, outras vezes um tanto emblemáticos e implícitos, os períodos curtos que compõem os provérbios podem mesmo ecoar na consciência do homem e, por conseguinte, ensinar-lhe alguma coisa; podem trazer também alguma espécie de conforto, ou de confiança, em determinadas situações da vida; são, igualmente, tentativas de correções que podem, eventualmente, ter eficácia, pois eles foram criados a partir de situações reais que, algum dia, alguém, muitas vezes pessoas anônimas, teve de enfrentar. Os provérbios e os pensamentos podem funcionar como lembretes para a vida ou, segundo Tolstói, em sua introdução ao Calendário,

\footnotetext{
${ }^{60}$ Ibidem, p. 235.

${ }^{61}$ Ibidem, p. 237 e 238.

${ }^{62}$ TOLSTÓI, Lev. Calendário da Sabedoria. (Trad. Bárbara Heliodora). $2^{\mathrm{a}}$ ed. Rio de Janeiro: Ediouro, 1999.

63 "O folclore urbano e a canção urbana na Rússia do século XX”. Curso ministrado na FFLCH-USP, de 17 de outubro de 2006 a 29 de janeiro de 2007.
} 
[...] o objetivo de meu livro [é] usar a vasta e frutífera herança intelectual criada por diferentes escritores a fim de apresentar a um amplo público leitor um círculo de leituras diárias de fácil acesso, que lhes despertarão seus melhores pensamentos e sentimentos ${ }^{64}$.

\section{$\underline{\text { Livros de Leitura }}$}

Os textos que compõem os Livros de Leitura foram classificados em vários gêneros: fábulas, histórias verdadeiras, raciocínios, contos, descrições, contos maravilhosos, relatos de um senhor de terras, relatos históricos, relatos de um mujique, relatos de um oficial, relatos de um caçador, bylinas.

De acordo com Charles Salomon, tradutor francês, contemporâneo de Tolstói, a primeira edição dos Livros de Leitura trazia uma ordem diferente daquela apresentada e mantida em edições subsequentes ${ }^{65}$; nela, às fábulas e a outros textos adaptados, seguiam-se os textos de autoria de Tolstói.

Segue abaixo a lista de equivalência dos gêneros em minha tradução para a língua de chegada:

басня - fábula

быль - história verdadeira

описание - descrição

рассказ - conto

рассуждение - raciocínio

сказка - conto maravilhoso

рассказ барина - relato de um senhor de terras

история - relato histórico

рассказ мужика - relato de um mujique

рассказ офицера - relato de um oficial

рассказ охотника - relato de um caçador

Tolstói conclui cada um de seus Livros de Leitura com bylinas: duas no primeiro e uma nos demais livros. Termo derivado de быль, ou «acontecimento,

\footnotetext{
${ }^{64}$ Ibidem, p. 12.

${ }^{65}$ TOLSTOÏ, Léon. Les Quate Livres de Lecture. (Trad. e pref. Charles Salomon). Paris: Éditions Bossard, 1928. p. 32.
} 
sucesso, feito verídico», as bylinas - narrativas épicas em verso - foram excluídas das versões em português dos Livros de Leitura ${ }^{66}$, seja no primeiro, já publicado; no segundo, já traduzido; bem como no terceiro, objeto deste trabalho. Acredito que traduzi-las agora não caberia a esta Dissertação, pois a complexidade desse tipo de poesia demanda estudos mais profundos, que fugiriam à minha intenção principal, quer seja, a tradução da prosa contida nos Livros de Leitura.

O Primeiro Livro de Leitura é composto de 27 fábulas, 15 histórias verdadeiras, 4 contos, 4 contos maravilhosos, 3 descrições, 2 bylinas, 1 raciocínio, 1 conto de um senhor de terras, além de um texto, «Um mujique conta por que ama muito seu irmão mais velho», оu Рассказ мужика о том, за что он старшего брата своего любит, sem gênero apontado na edição original em russo, mas classificado como «relato de um camponês» na tradução de M. Aparecida B. P. Soares.

No Segundo Livro de Leitura há 28 fábulas, 14 histórias verdadeiras, 6 contos maravilhosos, 5 contos, 5 raciocínios, 2 descrições, 2 relatos históricos, 1 bylina.

Do Terceiro Livro de Leitura, constam 19 fábulas, 8 contos, 7 raciocínios, 5 contos maravilhosos, 3 descrições, 3 relatos históricos, 1 relato de um senhor de terras, 1 relato de um camponês, 1 relato de um oficial, 1 história verdadeira; 1 bylina.

Finalmente, no Quarto Livro de Leitura, encontram-se 14 fábulas, 6 raciocínios, 4 contos maravilhosos, 4 contos, 3 histórias verdadeiras, 1 relato histórico, 1 relato de um caçador, 1 bylina, e, tal como no Primeiro Livro de Leitura, um texto, «Relato de um aeronauta», ou Рассказ аэронавта, igualmente sem definição de gênero impressa na edição russa.

Abundantes no primeiro livro, as fábulas são menos numerosas nos demais: 27 no primeiro, 14 no segundo, 19 no terceiro e 14 no quarto. $O$ mesmo ocorre com as histórias verdadeiras: 15 no primeiro, 14 no segundo, 1 no terceiro e 3 no último. Há maior equilíbrio na ocorrência dos outros gêneros distribuídos pelos quatro livros, e não foi por mero acaso que Tolstói serviu-se de tantas fábulas, adaptando-as em seus livros de leitura, pois elas são lúdicas, instrutivas e enigmáticas ao mesmo tempo, o que, sem dúvida, desperta a curiosidade e o interesse da criança, levando-a a refletir sobre a própria história que lhe contam ou que ela lê.

\footnotetext{
${ }^{66}$ L.N. TOLSTÓI. Contos da Nova Cartilha - Primeiro Livro de Leitura (Trad. M. Aparecida B. P. Soares). São Paulo: Ateliê Editorial, 2005.
} 
Algumas vezes, Tolstói parece não se preocupar muito com critérios rígidos para determinar o gênero de seus textos. Para diferenciarmos os gêneros «fábula»e «conto» nos quatro livros, é necessário, muitas vezes, opô-los às «histórias verdadeiras», ou seja, as fábulas são textos que contêm elementos pertencentes à irrealidade; os contos, por sua vez, são histórias possíveis de acontecer, compostas de elementos que não contrariam possibilidades reais apresentadas pela vida.

De acordo com Maria Celeste Consolin Dezotti, organizadora do livro $A$ tradição da Fábula - de Esopo a La Fontaine ${ }^{67}$, fatores culturais determinam a estrutura dos textos, bem como os temas e as figuras das fábulas. A autora propõe, ainda, uma definição para esse gênero: «Fábula é um ato de fala que se realiza por meio de uma narrativa. Logo, ela constitui um modo poético de construção discursiva, em que o narrar passa a ser o meio de expressão do dizer.» ${ }^{68}$

Assim, dentre outras, sua função pode ser mostrar, aconselhar ou censurar, e, à narrativa, deve estar vinculado um discurso alegórico que abriga uma espécie de moral ou de lição, um outro significado, enfim. A narrativa deve, portanto, ser interpretada pelo leitor ou pelo ouvinte, ou traduzida pelo autor da fábula e, neste caso, é necessário que ele próprio forneça uma moral. No entanto, à excessão de uma fábula, Рьбак и рыбкка, ou «O pescador e o peixinho», do Segundo Livro, todas as outras fábulas adaptadas por Tolstói parecem não carregar conclusões morais explícitas:

Поймал рыбак рыбку. Рыбка и говорит:

«Рыбак, пусти меня в воду; видишь, я мелка: тебе от меня пользы мало будет. А пустишь, да я вырасту, тогда поймаешь - тебе пользы больше будет».

\section{Рыбак и говорит:}

«Дурак тот будет, кто станет больщой пользы ждать, а малую из рук упустит». Um pescador pescou um peixinho. O peixinho disse:

- Pescador, devolva-me à água; veja, eu sou miudinho, você quase não terá proveito comigo. Mas, se você me soltar, eu crescerei, e quando você me pescar novamente, terá um proveito maior.

O pescador respondeu:

— Tolo é aquele que, por esperar um proveito grande, deixa um menor escapar das mãos.

\footnotetext{
${ }^{67}$ A Tradição da Fábula: de Esopo a La Fontaine. (Org. Maria Celeste Consolin Dezotti). Brasília: Editora Universidade de Brasília: São Paulo: Imprensa Oficial do Estado de São Paulo, 2003.

${ }^{68}$ Ibidem, p. 22.
} 
No texto acima, a moral faz parte da fala do personagem, e a estrutura gramatical «Tolo é aquele que», que anuncia a moral, equivale à fórmula característica «a fábula mostra que», ou «esta fábula aplica-se àqueles que».

Ao contrário, como ocorre nas outras fábulas que compõem todos os Livros de Leitura, em «O rei e o falcão», ou Царь и сокол, do Terceiro Livro, a moral permanece implícita no texto:

O rei disse:

- Como fui idiota ao me vingar do falcão: ele salvou a minha vida e eu matei-o.

Julgo importante salientar que os Livros de Leitura não têm caráter moralista, como também observa a Professora Aurora F. Bernardini em seu prefácio à edição do Primeiro Livro de Leitura:

[...] Fora da Rússia, os contos de seus Livros de Leitura, traduzidos nas línguas mais diversas, foram lidos e apreciados por milhões de crianças que se empolgaram com a sobriedade e a precisão da expressão, com as fórmulas breves e as conclusões sem retórica moralizante. ${ }^{69}$

Bastante numerosas na obra de Tolstói, as fábulas esópicas, de maneira geral, trazem, em primeiro lugar, a narrativa, que apresenta a situação e os personagens:

Uma raposa caiu numa armadilha, perdeu a sua cauda nela e fugiu. Então, ela começou a inventar um jeito de esconder a sua vergonha. Chamou as outras raposas e tentou convencêlas a cortarem suas caudas.

- A cauda - disse ela - é toalmente inútil; não passa de um peso desnecessário que carregamos.

Em seguida, há uma espécie de interpretação, ou conclusão, da narrativa:

Então, uma raposa disse:

- Ah, você não diria isso se não estivesse estropiada.

A raposa estropiada calou a boca e foi-se embora. ${ }^{70}$

Nenhuma das fábulas adaptadas por Tolstói está versificada. De acordo com Maria Celeste C. Dezotti, esse gênero nunca foi formalizado em esquemas métricos, ao contrário, a natureza da fábula é prosástica. Dezotti ainda considera que a fábula constituiu-se em gênero autônomo «com o advento, entre os gregos, da prosa como expressão literária, durante o século VI a.C. ${ }^{71} \mathrm{~A}$ pesquisadora esclarece que, ao

\footnotetext{
${ }^{69}$ Ibidem, p. 23.

${ }^{70}$ A raposa. In Contos da Nova Cartilha-Terceiro Livro de Leitura.

${ }^{71}$ Cf. p. 26.
} 
contrário da ideia comum de que a fábula conta apenas histórias de animais que falam, também deuses, plantas, homens, objetos e entidades abstratas podem ser personagens desse gênero, gerando vários tipos de fábulas, como, por exemplo, as «anedóticas», de que participam exclusivamente personagens humanos; as «etiológicas», cujo objetivo é o de explicar algum aspecto do mundo natural; as «zoológicas», que tratam dos comportamentos peculiares de determinadas espécies de animais; as «mitológicas», em que os deuses são personagens; etc.

Certamente Tolstói conhecia as fábulas de Loqman ${ }^{72} \mathrm{e}$, sem dúvida, as fontes indianas provieram de Bidpay, ou Bilpay.

A título de curiosidade, no capítulo sobre Esopo, do livro organizado por M. Celeste C. Dezotti, descobri que muitos dos textos a ele atribuídos são textos anônimos; sequer sabe-se se Esopo escreveu-os ou coligiu-os. Alguns estudiosos afirmam que ele não existiu, e que o nome foi inventado para «canalizar» obras anônimas; outros dizem que Esopo foi um escravo que viveu na Grécia. Seja como for, é evidente a preferência de Tolstói por Esopo, e não por La Fontaine, por exemplo. Em 1870, quando escreve os Livros de Leitura, Tolstói estuda - e aprende sozinho - o grego. Em uma carta escrita ao poeta russo Fet, Tolstói demonstra o seu entusiasmo pela literatura grega e, especialmente pelo fabulista grego Esopo: "Em nome do céu, explique-me por que ninguém conhece as fábulas de Esopo, nem mesmo o delicioso Xenofonte, sem falar de Platão e de Homero.”

Além disso, ao contrário de La Fontaine, Esopo é conciso, simples e direto, bem ao gosto de Tolstói, ao menos em seus Livros de Leitura.

A primeira edição dos Quatro Livros de Leitura traz uma nota do autor:

Os textos cuja origem não foi indicada pertencem ao autor. Aqueles que foram extraídos de várias fontes foram tão transformados que, frequentemente, eles têm do original pouquíssimo em comum. As fábulas de Esopo e os contos de Heródoto sofreram poucas alterações. Para a redação das bylinas, diferentes versões foram reunidas e respeitaram-se as regras da versificação russa. ${ }^{73}$

Assim, na primeira edição dos Livros de Leitura, Tolstói indicou as fontes de vários textos. Segue abaixo uma lista de alguns títulos de textos com suas respectivas fontes, indicadas pelo autor, e/ou pesquisadas por Charles Salomon:

\footnotetext{
${ }^{72}$ Loqman, o Sábio. Fabulista árabe.

${ }^{73}$ TOLSTOÏ, Léon. Les Quate Livres de Lecture. (Trad. e pref. Charles Salomon). Paris: Éditions Bossard, 1928, p. 535.
} 


\section{$\underline{\text { Primeiro Livro }}$}

«A formiga e a pomba» - fábula

Fonte indicada por Tolstói: Esopo

Esopo: «A formiga e a pomba»

La Fontaine: «La colombe et la fourmi»

«O cego e o surdo» - história verdadeira

«A tartaruga e a águia» - fábula

Fonte indicada por Tolstói: Esopo

Esopo: «A tartaruga e a águia», ou «Aquila et Cornex»

La Fontaine: «La tortue et les deux canards»

«O enjeitado» - história verdadeira

Fonte não indicada por Tolstói

Segundo Charles Salomon, na primeira edição russa esse texto fora classificado como «fábula», mas trata-se de uma «história verdadeira». ${ }^{74}$

«A cabeça e o rabo da cobra» - fábula

Fonte indicada por Tolstói: indiana

Esopo: «A cauda e o corpo da serpente»

La Fontaine: «La teste et la queue du serpent»

«A pedra»- história verdadeira

«Os esquimós» - descrição

«O furão» - fábula

Fonte indicada por Tolstói: Esopo

Esopo: «A doninha e a lima», ou «Serpens ad fabrum ferrarium»

${ }^{74}$ Ibidem, p. 487. 
La Fontaine: «Le serpent et la lime»

«A tia conta como aprendeu a costurar» - conto

De acordo com Charles Salomon, este conto foi escrito por Sofia Tolstáia e corrigido por seu marido, Lev Tolstói ${ }^{75}$

«Linhas finas» - fábula

Fonte indicada por Tolstói: indiana

«Da velocidade vem a força» - história verdadeira

«O leão e o camundongo» - fábula

Fonte indicada por Tolstói: Esopo

Esopo: «O leão e o rato agradecido»

La Fontaine: «Le lion et le rat»

«Cães bombeiros» - história verdadeira

«O macaco» - fábula

Fonte indicada por Tolstói: indiana

Bidpay: «De um marceneiro e de um macaco»

«Um menino conta como não o levaram à cidade» - conto

De acordo com Charles Salomon, esta história foi contada a Tolstói por um dos alunos da escola de Iásnaia Poliana. ${ }^{76}$

«O mentiroso» - fábula

Fonte indicada por Tolstói: Esopo

Esopo: «O pastor que fazia gracinhas»

«Como na cidade de Paris consertaram uma casa» - história verdadeira

\footnotetext{
${ }^{75}$ TOLSTOÏ, Léon. Les Quate Livres de Lecture. (Trad. e pref. Charles Salomon). Paris: Éditions Bossard, 1928, p. 487.

${ }^{76}$ Ibidem, p. 488.
} 
«O burro e o cavalo» - fábula

Fonte indicada por Tolstói: Esopo

Esopo: «O cavalo e o asno»

La Fontaine: «Le cheval et l'asne»

«Um menino conta como foi surpreendido no bosque por uma tempestade» - história verdadeira

«A gralha e os pombos» - fábula

Fonte indicada por Tolstói: Esopo

Esopo: «Graculus superbus et pavo»

La Fontaine: «Le geay paré des plumes»

«O mujique e os pepinos» - fábula

Fonte não indicada por Tolstói

«A mulher e a galinha» - fábula

Fonte indicada por Tolstói: Esopo

Esopo: «A mulher e a galinha»

Loqman: «A mulher e a galinha»

«O velho avô e o netinho» - fábula

Fonte não indicada por Tolstói

Segundo Charles Salomon, a fonte provém da obra dos Irmãos Grimm ${ }^{77}$

«A divisão da herança» - fábula

Fonte indicada por Tolstói: indiana

«Para onde vai a água do mar» - raciocínio

«O leão, o urso e a raposa» - fábula

Fonte indicada por Tolstói: Esopo

${ }^{77}$ Ibidem, p. 489. 
Esopo: «O leão, o urso e a raposa»

La Fontaine: «Les voleurs et l'asne»

«Um menino conta como achou abelhas-rainhas» - conto

«O cachorro, o galo e a raposa» - fábula

Fonte indicada por Tolstói: Esopo

Esopo: «O cachorro, o galo e a raposa»

La Fontaine: «Le coq et le renard»

«O mar» - descrição

«O cavalo e o cavalariço» - fábula

Fonte indicada por Tolstói: Esopo

Esopo: «O cavalo e o palafreneiro»

«O incêndio» - história verdadeira

«A rã e o leão» - fábula

Fonte indicada por Tolstói: Esopo

Esopo: «O leão e a rã»

«O elefante» - história verdadeira

«O macaco e as ervilhas» - fábula

Fonte indicada por Tolstói: indiana

«Um menino conta como perdeu o medo dos mendigos cegos» - conto

Para Charles Salomon, trata-se de uma recordação da própria infância de Tolstói. ${ }^{78}$

«A vaca leiteira» - fábula

Fonte indicada por Tolstói: indiana

${ }^{78}$ Ibidem, p. 490. 
«A imperatriz chinesa Si-ling-chi»- história verdadeira

«A libélula e as formigas» - fábula

Fonte indicada por Tolstói: Esopo

Esopo: «A cigarra e as formigas»

La Fontaine: «La cigale et la fourmy»

«A menina-camundongo»- conto

Fonte indicada por Tolstói: indiana

«A galinha dos ovos de ouro» - fábula

Fonte indicada por Tolstói: Esopo

Esopo: «A galinha dos ovos de ouro»

La Fontaine: «La poule aux oeufs d'or»

«Lipúniuchka»-conto

Fonte indicada por Tolstói: popular

«O lobo e a velha» - fábula

Fonte indicada por Tolstói: Esopo

Esopo: «O lobo e a velha»

La Fontaine: «Le loup, la mère et l'enfant»

«O gatinho» - história verdadeira

«O filho sábio» - fábula

Fonte não indicada por Tolstói

«Como os habitantes de Bucara aprenderam a criar bichos-da-seda» - história verdadeira

«O mujique e o cavalo» - fábula

Fonte não indicada por Tolstói 
«Titia conta à vovó como Emielka Pugatchov lhe deu uma moeda de dez copeques»história verdadeira

«O vizir Abdul» - conto

«Como um ladrão traiu a si mesmo» - história verdadeira

«O fardo» - fábula

Fonte não indicada por Tolstói

«O carocinho» - história verdadeira

Segundo Charles Salomon, a história ocorreu a uma parente afastada de Tolstói. ${ }^{79}$

«Os dois mercadores» - fábula

Fonte não indicada por Tolstói

Bidpay: «De um mercador e de seu amigo»

La Fontaine: «Le dépositaire infidèle»

«O cão de São Gotardo» - descrição

«Um mujique conta por que ama muito seu irmão mais velho» - relato de um camponês

«Como matei minha primeira lebre» - conto de um senhor de terras

De acordo com Charles Salomon, trata-se de uma recordação, um tanto fantasiosa, da infância de Tolstói. ${ }^{80}$

«O Pequeno Polegar»-conto

Fonte não indicada por Tolstói

${ }^{79}$ Ibidem, p. 492.

${ }^{80}$ Ibidem, p. 493. 


\section{Segundo Livro}

«A menina e os cogumelos» - história verdadeira

«O burro na pele de um leão» - fábula

Fonte indicada por Tolstói: Esopo

Esopo: «O asno que se passava por leão»

La Fontaine: «L'asne vestu de la peau du lion»

«Como o orvalho se forma sobre a relva» - descrição

«A galinha e a andorinha» - fábula

Fonte indicada por Tolstói: Esopo

Esopo: «A galinha e a andorinha»

«O índio e o inglês» - história verdadeira

Fonte indicada por Tolstói: norte-americana

«O cervo e o veadinho» - fábula

Fonte indicada por Tolstói: Esopo

Esopo: «O filhote de corça e o pequeno veado»

«A veste» - história verdadeira

«A raposa e as uvas» - fábula

Fonte indicada por Tolstói: Esopo

Esopo: «A raposa e as uvas», ou «De vulpe et uva»

La Fontaine: «Le renard et les raisins»

«Sorte»- história verdadeira

Fonte indicada por Tolstói: indiana

«As empregadas e o galo» - fábula 
Fonte indicada por Tolstói: Esopo

Esopo: «A mulher e as empregadas»

La Fontaine: «La vieille et les deux servantes»

«O moinho auto-giratório» - história verdadeira

«O pescador e o peixinho» - fábula

Fonte indicada por Tolstói: Esopo

Esopo: «O pescador e o pequeno peixe»

La Fontaine: «Le petit poisson et le pescheur»

«O tato e a visão» - raciocínio

«A raposa e o bode» - fábula

Fonte indicada por Tolstói: Esopo

Esopo: «A raposa e o bode», ou «In periculum simul ac venit callidus vulpis et caper»

La Fontaine: «Le renard et le bouc»

Loqman: «A gazela e a raposa»

«Como um mujique retirou uma pedra» - história verdadeira

«O cachorro e a sua sombra» - fábula

Fonte indicada por Tolstói: Esopo

Esopo: «O cachorro que carregava um pedaço de carne», ou «Canis per fluvium carnem ferens»

La Fontaine: «Le chien que lâche sa proye pour l'ombre»

Loqman: «O cachorro e o milhafre»

«Chat e Don»- conto

Fonte indicada por Tolstói: popular

«A grua e a cegonha» - fábula

Fonte indicada por Tolstói: Esopo

Esopo: «O passarinheiro e a cegonha» 
«Sudoma»-conto

Fonte indicada por Tolstói: Piotr Mirónovitch Perevléski ${ }^{81}$

«O jardineiro e seus filhos» - fábula

Fonte indicada por Tolstói: Esopo

Esopo: «O lavrador e seus filhos»

La Fontaine: «Le laboureur et ses enfants»

«A coruja e a lebre» - fábula

Segundo Charles Salomon, trata-se, provavelmente, de uma lembrança da época em que Tolstói costumava caçar. ${ }^{82}$

«O lobo e a cegonha» - fábula

Fonte indicada por Tolstói: Esopo

Esopo: «O lobo e a garça», ou «Lupus et gruis»

La Fontaine: «Le loup et la cigogne»

«A águia» - história verdadeira

Fonte indicada por Tolstói: norte-americana

«O pato e a lua» - fábula

Fonte indicada por Tolstói: indiana

«O urso na carroça» - fábula

Fonte não indicada por Tolstói

«O lobo na poeira» - fábula

Fonte indicada por Tolstói: indiana

«O salgueiro» - história verdadeira

«O rato embaixo do celeiro» - fábula

${ }_{82}^{81}$ Escritor e pedagogo, falecido em 1866. Filho de um diácono de Riazan.

${ }^{82}$ Ibidem, p. 498. 
Fonte indicada por Tolstói: indiana

«Como os lobos ensinam seus filhos» - conto

«As lebres e as rãs» - fábula

Fonte indicada por Tolstói: Esopo

Esopo: «As lebres e as rãs»

La Fontaine: «Le lièvre et les grenouilles»

«Titia conta como um pardal chamado Vivinho foi domesticado» - conto

«Três broas e uma rosca» - fábula

Fonte indicada por Tolstói: indiana

«Mil moedas de ouro» - história verdadeira

Fonte indicada por Tolstói: francesa

«Piotr e o mujique» - história verdadeira

Fonte indicada por Tolstói: Bezsónov ${ }^{83}$

«O cachorro valente» - história verdadeira

«Dois cavalos» - fábula

Fonte não indicada por Tolstói

«O leão e o cachorrinho» - história verdadeira

Fonte indicada por Tolstói: norte-americana

«A herança justa» - fábula

Fonte não indicada por Tolstói

«Três ladrões»- história verdadeira

${ }^{83}$ P.A. Bezsónov, 1828-1898. Editor e estudioso de cantos populares russos. 
Fonte indicada por Tolstói: Hebel ${ }^{84}$

«O pai e os filhos» - fábula

Fonte indicada por Tolstói: Esopo

Esopo: «Os filhos desunidos do lavrador»

La Fontaine: «Le vieillard et ses enfants»

«Por que existe o vento?»-raciocínio

«Para que serve o vento?»-raciocínio

«As melhores peras» - fábula

Fonte indicada por Tolstói: indiana

«Volga e Vazuza» - conto

Fonte indicada por Tolstói: Dal ${ }^{85}$

«O bezerro sobre o gelo» - fábula

Fonte não indicada por Tolstói

«A mahani dos cabelos de ouro» - conto

Fonte indicada por Tolstói: Tchijov ${ }^{86}$

«O falcão e o galo» - fábula

Fonte indicada por Tolstói: indiana

Bidpay: «De um falcão e de uma galinha»

La Fontaine: «Le faucon et le chapon»

$« \mathrm{O}$ calor $\mathrm{I} »-$ raciocínio

«O calor II - raciocínio

\footnotetext{
${ }^{84}$ Jean-Pierre Hebel, 1760-1826. Escritor popular, nascido na Basileia.

${ }^{85}$ V.I. Dal, 1801-1872. Etnógrafo e lexicógrafo, autor do clássico Dicionário da Língua Russa. Dal foi também grande conhecedor de cantos, histórias e tradições populares russos.

${ }^{86}$ Fiodor Vassílievitch Tchijov, 1811-1877. Eslavista.
} 
«O calor III» - raciocínio

«Os chacais e o elefante» - fábula

Fonte indicada por Tolstói: indiana

«A pedra-ímã» - descrição

«A garça, os peixes e o lagostim» - fábula

Fonte indicada por Tolstói: indiana

Bidpay: «De um grou e de um lagostim»

La Fontaine: «Les poissons et le cormoran»

«Titio conta como aprendeu a montar» - conto

Segundo Charles Salomon, os três irmãos da história são Nikolai, Serguei, Dmítri e Lev Tolstói. Pímen Timoféitch, ainda de acordo com Salomon, era um homem velho, corcunda devido à idade, e que morreu em Iásnaia Poliana, onde se passou essa história. $^{87}$

«O ouriço e a lebre» - fábula

Fonte indicada por Tolstói: alemã, provavelmente, os Irmãos Grimm

La Fontaine: «Le lièvre et la tortue»

«Dois irmãos» - conto

Fonte indicada por Tolstói: árabe.

De acordo com Salomon, a fonte é indiana. ${ }^{88}$

Bidpay: «Dos dois viajantes e de um leão de pedra branca»

La Fontaine: «Les deux aventuriers et le talisman»

«O espírito das águas e a pérola» - fábula

Fonte indicada por Tolstói: indiana

«A cobra d'água» - conto

${ }^{87}$ Ibidem, p. 501.

${ }^{88}$ Ibidem, p. 501. 
Fonte indicada por Tolstói: popular

«O pardal e as andorinhas» - conto

Fonte indicada por Tolstói: Perevleski

«Cambises e Psamético» - relato histórico

Fonte indicada por Tolstói: Heródoto

«O tubarão» - conto

Fonte indicada por Tolstói: norte-americana

«Por que os vidros das janelas suam e existe o orvalho?»-raciocínio

«O bispo e o salteador» - história verdadeira

Fonte indicada por Tolstói: Victor Hugo, da obra Les Misérables

«Ermak» - relato histórico

\section{$\underline{\text { Terceiro Livro }}$}

«O rei e o falcão» - fábula

Fonte indicada por Tolstói: indiana

«A raposa» - fábula

Fonte indicada por Tolstói: Esopo

Esopo: «A raposa amputada»

La Fontaine: «Le renard ayant la queüe coupée»

«Severa punição» - conto

Fonte indicada por Tolstói: árabe 
«O burro arisco e o burro manso» - fábula

Fonte indicada por Tolstói: Esopo

Esopo: «O asno selvagem e o asno domesticado»

La Fontaine: «Le loup et le chien»

«A lebre e o galgo»: fábula

Fonte não indicada por Tolstói

«O cervo» - fábula

Fonte indicada por Tolstói: Esopo

Esopo: «O cervo na fonte e o leão», ou «Cervus ad fontem»

La Fontaine: «Le cerf se voyant dans l'eau»

Loqman: «A gazela»

«As lebres»-descrição

«O cachorro e o lobo» - fábula

Fonte indicada por Tolstói: Esopo

Esopo: «O cachorro adormecido e o lobo»

La Fontaine: «Le loup et le chien maigre»

«Os irmãos do rei» - conto maravilhoso

Fonte indicada por Tolstói: Hebel

«O cego e o leite» - fábula

Fonte indicada por Tolstói: indiana

«A lebre das estepes» - descrição

«O lobo e o arco» - fábula

Fonte indicada por Tolstói: indiana

Bidpay: «De um caçador e de um lobo»

La Fontaine: «Le loup et le chasseur» 
«Como um mujique repartiu os gansos» - conto maravilhoso

Fonte não indicada por Tolstói

«O mosquito e o leão» - fábula

Fonte indicada por Tolstói: Esopo

Esopo: «O mosquito e o leão»

La Fontaine: «Le lion et le moûcheron»

Loqman: «O mosquito e o touro»

«As macieiras» - conto

«O cavalo e seus donos» - fábula

Fonte indicada por Tolstói: Esopo

Esopo: «O asno e o jardineiro»

La Fontaine: «L'asne et ses maistres»

«Os percevejos»- conto

«O velho e a morte» - fábula

Fonte indicada por Tolstói: Esopo

Esopo: «O velho e a morte»

La Fontaine: «L'homme et la mort»

«Como os gansos salvaram Roma» - conto histórico

Fonte indicada por Tolstói: Plutarco

«Por que as árvores estalam no frio?»- raciocínio

«Umidade I» - raciocínio

«Umidade II»-raciocínio

«Diferente ligação entre partículas» - raciocínio 
«O leão e a raposa» - fábula

Fonte indicada por Tolstói: Esopo

Esopo: «O velho leão e a raposa»

La Fontaine: «Le lion malade et le renard»

Loqman: «O leão e a raposa»

«O juiz justo» - conto maravilhoso

Fonte indicada por Tolstói: oriental

«O cervo e o vinhedo» - fábula

Fonte indicada por Tolstói: Esopo

Esopo: «A corça e o vinhedo»

La Fontaine: «Le cerf et la vigne»

«O filho do rei e seus companheiros» - conto maravilhoso

Fonte indicada por Tolstói: turca

Bidpay: «História de Asfendiar»

La Fontaine: «Le marchand, le gentilhomme, le pâtre et le fils de roy»

«O filhote de gralha» - fábula

Fonte não indicada por Tolstói

Bidpay: «De um derviche, de um falcão e de um corvo»

«Como aprendi a cavalgar» - conto de um senhor de terras

«O machado e a serra» - fábula

Fonte não indicada por Tolstói

«Vida de um soldado» - conto de um mujique

Autoria de Vassíli Morózov, um dos alunos da escola de Iásnaia Poliana

«O gato e os ratos» - fábula

Fonte indicada por Tolstói: Esopo

Esopo: «O gato e os ratos» 
La Fontaine: «Le chat et le vieux rat»

«O gelo, a água e o vapor» - raciocínio

«A codorna e seus filhotes» - fábula

Fonte não indicada por Tolstói

«Bulka» - relato de um oficial

«Bulka e o javali» - conto

«Os faisões» - descrição

«Milton e Bulka» - conto

«A tartaruga» - conto

«Bulka e o lobo»- conto

«O que aconteceu com Bulka em Piatigorsk» - conto

«O fim de Bulka e de Milton» - conto

«Os pássaros e as redes» - fábula

Fonte indicada por Tolstói: indiana

«O olfato» - raciocínio

«Os cães e o cozinheiro» - fábula

Fonte não indicada por Tolstói

«A fundação de Roma» - conto histórico

Fonte indicada por Tolstói: Plutarco 
«Deus diz a verdade, mas não a diz logo» - história verdadeira

«Cristais» - raciocínio

«O lobo e a cabra» - fábula

Fonte indicada por Tolstói: Esopo

Esopo: «O lobo e a cabra»

«Polícrates de Samos» - relato histórico

\section{Quarto Livro $^{89}$}

«Царь и рубашка»-сказка (conto)

Fonte indicada por Tolstói: árabe

«Камыиш и маслина» - басня (fábula)

Fonte indicada por Tolstói: Esopo

Esopo: «O junco e a oliveira»

La Fontaine: «Le chesne et le rozeau»

«Волк и мужик» - сказка (conto)

Fonte indicada por Tolstói: popular

«Два товарища 》 - басня (fábula)

Fonte indicada por Tolstói: Esopo

Esopo: «Os viajantes e o urso»

La Fontaine: «L'ours et les deux compagnons»

«Прыжок» - быль (história verdadeira)

Fonte indicada por Tolstói: norte-americana

${ }^{89}$ O Quarto Livro de Leitura ainda não foi traduzido para o português. Os títulos do quadro referente a este livro foram, portanto, traduzidos da versão francesa, de Charles Salomon. 
«Дуб и орешник» - басня (fábula)

Fonte não indicada por Tolstói

«Вредныий воздухх» - былль (história verdadeira)

«Дурной воздух» - рассуждение (raciocínio)

«Волк и ягненок» - басня (fábula)

Fonte indicada por Tolstói: Esopo

Esopo: «O lobo e o cordeiro» ou «Lupus et agnus»

La Fontaine: «Le loup et l'agneau»

«Удельный вес»-история (relato histórico)

«Лев, волк и лисица » - басня (fábula)

Fonte indicada por Tolstói: Esopo

Esopo: «O leão, o lobo e a raposa»

La Fontaine: «Le lion, le loup et le renard»

«Царское новое платье»-сказка (conto)

Fonte indicada por Tolstói: Andersen

«Лисий хвост» - басня (fábula)

Fonte não indicada por Tolstói

«Шелковичный червь»-рассказ (conto)

«Царь и слоньл» - басня (fábula)

Fonte indicada por Tolstói: indiana

«Охота пуще неволи» - рассказ охотника (relato de um caçador)

«Наседка и ирыплята» - басня (fábula)

Fonte não indicada por Tolstói 
«Газы I»-рассуждение (raciocínio)

«Газы II»-рассуждение (raciocínio)

«Лев, осел и лисища »- басня (fábula)

Fonte não indicada por Tolstói

Esopo: «O leão, o asno e a raposa»

«Старый тополь»-рассказ (conto)

«Мужик и водяной» - басня (fábula)

Esopo: «O lenhador e Hermes»

La Fontaine: «Le buscheron et Mercure»

«Ворон и лисища» - басня (fábula)

Esopo: «O corvo e a raposa» ou «Vulpis et corvus»

La Fontaine: «Le corbeau et le renard»

Deveríamos crer que as fábulas cujas fontes não foram indicadas seriam de autoria de Tolstói, no entanto, pude verificar que algumas delas encontram-se reunidas em uma coletânea de fábulas russas, intitulada Enciclopédia Universal da Fábula - Fábulas, Mitos e Lendas Populares. ${ }^{90}$ Dentre outras, gostaria de citar: $« \mathrm{O}$ leão e o ratinho», ou Лев и Mbıшь (Primeiro Livro de Leitura: «O leão e o camundongo»; «O camponês e o cavalo», ou Мужик и лошадь (Primeiro Livro de Leitura: «O mujique e o cavalo» ${ }^{91}$ ); «Os dois cavalos», ou Две ломади (Segundo Livro de Leitura: «Dois cavalos»), todas de autoria de Krylov $^{92}$, de acordo com a enciclopédia.

Na mesma coletânea, localizei outros textos: «A cabeça e a cauda da cobra», оu Голова и хвост змеи (Primeiro Livro de Leitura: «A cabeça e o rabo da

\footnotetext{
${ }^{90}$ Enciclopédia Universal da Fábula - Fábulas, Mitos e Lendas Populares. (Coord. A. Della Nina). São Paulo: Editora das Américas, 1957. Vol. XI.

${ }^{91}$ Ibidem, p. 129.

${ }^{92}$ Ivan Krylov. (1769-1844). Importante fabulista russo. Baseou-se em Esopo e em Jean de la Fontaine para escrever as suas primeiras obras. Depois, manteve um trabalho original.
} 
cobra» ${ }^{93}$ ); "Quem tudo quer...», ou Mыıьь под амбаром (Segundo Livro de Leitura: «O rato embaixo do celeiro»); «O macaco e os grãos de ervilha», ou Обезьяна $и$ zopox (Primeiro Livro de Leitura: «O macaco e as ervilhas» ${ }^{94}$ ) — segundo Tolstói, todos inspirados em fontes indianas - e, por último, «O porco-espinho e a lebre», ou Еж и заяи (Segundo Livro de Leitura: «O ouriço e a lebre») — de fonte alemã, segundo Tolstói.

É evidente que Tolstói não deu grande importância à questão das fontes de origem de seus textos nem à sua classificação em gêneros; assim, de acordo com a nota do autor à primeira edição, deveríamos considerar que o texto «O pequeno polegar» ${ }^{95}$, dentre outros, é de autoria de Tolstói, pois sua fonte não está indicada no índice.

Sem me estender sobre o assunto, gostaria de apontar algumas observações que chamaram minha atenção: surpreendeu-me, por exemplo, que Tolstói tenha classificado como «fábula» o texto «A coruja e a lebre», pertencente ao Segundo Livro; trata-se, provavelmente, de lembranças de uma das caçadas que, na juventude, ele costumava praticar. Charles Salomon diz que a edição de 1872 da Cartilha não apresentava o gênero desse texto ${ }^{96}$. Nesse caso, arriscarei uma possibilidade: se, de fato, não se trata de uma fábula adaptada por Tolstói, talvez ele próprio tenha encontrado - ou essa história fora-lhe contada por alguém - garras de uma coruja fincadas sob a pele do dorso de uma lebre que tenha matado, e isso o levou a imaginar uma história que explicasse aquele «fenômeno». Concluída, a história tinha a estrutura de uma fábula: a narrativa mostra os personagens e o cenário, os animais conversam e raciocinam, um é mais astuto do que o outro, a lebre embeleza-se, etc. De minha parte, embora tenha obedecido, sempre que possível, à escolha de Tolstói, surpreendeu-me, de maneira particular a classificação de alguns textos. No Primeiro Livro, por exemplo, «O cego e o surdo», classificado de história verdadeira; encontro a seguinte possível justificativa: de um fato verídico, envolvendo uma pessoa cega e outra surda, Tolstói fez uma história fantasiosa e engraçada, que resultou em um outro gênero literário. «O avô e o netinho», classificado de fábula; é verdade que a história contém uma lição e uma reflexão, mas entendo que a melhor classificação seria história verdadeira ou conto. «O elefante», classificado de história verdadeira; no meu

\footnotetext{
${ }^{93}$ Ibidem, p. 35.

${ }^{94}$ Ibidem, p. 99.

${ }^{95}$ Versão literária de Charles Perrault.

${ }^{96}$ Ibidem, p. 498.
} 
modo de ver, trata-se de uma fábula de provável origem indiana. «A tia conta como aprendeu a costurar», classificado de conto; trata-se de um conto, mas poderia ser uma história verdadeira ou um relato. A mesma observação pode ser aplicada aos seguintes textos: «Um menino conta como não o levaram à cidade», «Um menino conta como achou abelhas-rainhas para o seu avô» e «Um menino conta como perdeu o medo dos mendigos cegos», todos eles classificados como conto. «Um menino conta como foi surpreendido por uma tempestade» está classificada como história verdadeira e, ainda que se trate de uma história contada por um dos alunos de Tolstói, poderia igualmente ser classificada como conto ou relato. «Titia conta a vovó como Emelka Pugatchov ${ }^{97}$ lhe deu uma moeda de dez copeques» — história verdadeira; nesse caso, a presença do personagem histórico Pugatchov, provavelmente, determinou o gênero do texto, mas outra possibilidade é a de que tal história tenha se passado com algum membro da família de Tolstói. «Um mujique conta por que ama muito seu irmão mais velho», relato de um camponês, poderia ser classificado também de conto ou de história verdadeira. «Como matei minha primeira lebre», relato, ou conto de um senhor de terras, uma história verdadeira, portanto.

No Segundo Livro, gostaria de apontar «O urso na carroça», classificado de fábula, mas que poderia ser um conto; e «O salgueiro», classificado de história verdadeira. A rigor, trata-se, de fato, de uma história verdadeira mas, no final, um corvo grita para a árvore "- Como é, seu pau velho, morreu? Já não era sem tempo.”, e animais falantes são, em geral, personagens de fábulas.

É verdade que, muitas vezes, o limite entre um gênero e outro é bastante delicado, e o próprio Tolstói opta ora por um, ora por outro: «O índio e o inglês», história verdadeira, mas de fonte americana. «Sorte», história verdadeira, mas de fonte indiana. «Como os lobos ensinam seus filhotes», conto que poderia perfeitamente ser uma história verdadeira ou, a rigor, uma descrição. «Titia conta como um pardal chamado Vivinho foi domesticado», conto que também poderia ser uma história verdadeira. «Mil moedas de ouro», história verdadeira, mas de fonte francesa, não encontrada nem mesmo por Charles Salomon. ${ }^{98}$ «Três ladrões», história verdadeira, cuja fonte é Jean-Pierre Hebel. «Titio conta como aprendeu a montar»,

\footnotetext{
${ }^{97}$ (1740 (42) - 1775). Camponês cossaco da região do Don. Depois de desertar da guerra russo-turca, em 1771, Pugatchov é preso várias vezes por vadiagem, foge da prisão de Kazan e orgtaniza uma revolta contra o feudalismo. Em 1774, derrotados pelo Exército russo, os cossacos aliam-se a o inimigo. Pugatchov é traído, capturado e decaptado em 1775.

${ }^{98}$ Ibidem, p. 499.
} 
conto; como alguns exemplos acima, esse texto poderia ser igualmente um relato ou uma história verdadeira. «O ouriço e a lebre», fábula cuja fonte, segundo Tolstói, são os Irmãos Grimm, poderia ser um conto maravilhoso; La Fontaine tem uma fábula Le lièvre et la tortue - aos moldes desse texto. E, finalmente, "A cobra d'água», conto, caberia também na categoria de conto maravilhoso. Tentativas de justificar a ausência de gênero, ou gêneros duvidosos, no entanto, nada são ao lado do interesse contido nessas histórias.

Nesses livros de Tolstói, entendo «conto maravilhoso» ${ }^{99}$, сказка, como contos fantasiosos, espécie de história da carochinha. Entendo «conto», ou рассказ, сото uma narração menos fantasiosa, podendo ser calcada em fatos reais ou imaginados, tal a encontrada nos textos «As macieiras», оu Яблони, е «Os percevejos», оu Клопьы, ambos do Terceiro Livro. Não obstante, conforme já mencionei, as linhas que separam alguns gêneros de outros são bastante tênues. Entendo «história verdadeira» como relato de um caso, de um episódio que realmente tenha ocorrido, especialmente na vizinhança de Iásnaia Poliana ou na família de Tolstói, ou, ainda, inspirado em leitura de livros, revistas e jornais. Nada me chamou atenção na distribuição dos textos entre os gêneros «raciocínio» e «descrição».

O texto «O cervo», ou Олень, incluído no Terceiro Livro, não tem sua fonte, Esopo, indicada por Tolstói; Charles Salomon lembra-nos ${ }^{100}$ de que o texto «O bispo e o salteador», ou Архиерей и разбойник, pertencente ao Segundo Livro, é uma criação de Victor Hugo, adaptada por Tolstói e por ele classificada de «história verdadeira».

Quanto ao gênero «relato histórico», Tolstói parece ter seguido um único critério, o seu gosto pessoal, pois são histórias interessantes, já que a sua intenção seria mais a de cativar o leitor - a história da fundação de Roma não é apenas interessante porque os personagens Rômulo, Remo e a loba agradam às crianças - e menos a de instruir, ensinando como Roma tornar-se-ia um grande império.

De modo geral, os temas dos «raciocínios» estão relacionados a fenômenos naturais, plantas e animais. Parece-me evidente que a fonte inspiradora deles resumese na vontade que Tolstói tinha de aprender e de ensinar, bem como na utilidade de a criança conhecer fenômenos que fazem parte de sua vida, como a formação de geadas, calor, etc.

\footnotetext{
${ }^{99}$ PROPP, Vladimir I. Comicidade e Riso. (Trad. Aurora F. Bernardini et alli). São Paulo: Ática, 1992.

${ }^{100}$ Ibidem, p. 503.
} 
A seguir, dois exemplos de fábulas de Esopo, retiradas do livro A Tradição da Fábula - de Esopo a La Fontaine, e as respectivas adaptações de Tolstói:

\section{$\underline{\text { Лисииа }}$ \\ Tolstói}

Попалась лиса в капкан, оторвала хвост и ушла. И стала она придумывать, как бы ей свой стыд прикрыть. Созвала она лисии и стала их уговаривать, чтоб отрубили хвосты. "Хвост, - говорит, - совсем не кстати, только напрасно лишнюю тягость за собой таскаем.» Одна лисица и говорит: «Ох, не говорила бы ты этого, кабы не была куцая!»

Куцая лисица смолчала и ушла.

\section{$\underline{\text { A raposa cotó }}^{101}$ \\ Esopo}

Uma raposa que teve o rabo mutilado em uma armadilha, ficou envergonhada e começou a achar insuportável a vida. Por isso, decidiu que precisava arrastar também as outras raposas à mesma situação, para disfarçar, com o padecimento comum, a sua desvantagem pessoal. Reuniu então todas as raposas e exortou-as a cortarem o rabo, dizendo que ele era não só um incômodo, mas também uma coisa supérflua, um peso grudado nelas. Então uma delas interrompeu e disse: «ô minha cara, só que se isso não lhe conviesse, você não nos faria tal proposta.»

Essa fábula se aplica àqueles que dão sugestões aos vizinhos, não em função do bom senso, mas em função do que convém a eles próprios.

\section{A raposa \\ Tolstói (Nossa tradução)}

Uma raposa caiu numa armadilha, perdeu a sua cauda nela e fugiu. Então, ela começou a inventar um jeito de esconder a sua vergonha. Chamou as outras raposas e tentou convencê-las a cortarem suas caudas.

${ }^{101}$ A Tradição da Fábula: de Esopo a La Fontaine. (org. Maria Celeste Consolin Dezotti). Brasília: Editora Universidade de Brasília: São Paulo: Imprensa Oficial do Estado de São Paulo, 2003. p. 64. 
- A cauda - disse ela -, é totalmente inútil; não passa de um peso desnecessário que carregamos.

Então, uma raposa disse:

- Ah, você não diria isso se não estivesse estropiada.

A raposa estropiada calou a boca e foi-se embora.

Tolstói é ainda mais sucinto do que Esopo. Suas orações são mais breves e mais diretas. A estrutura gramatical empregada na tradução do texto de Esopo é mais desenvolvida, com orações subordinadas, e sua narrativa estende-se bastante se comparada à narrativa de Tolstói. Notemos a maneira agradável, brincalhona até, que Tolstói encontrou para expressar o sentimento da raposa que acabara de perder a sua cauda: ela queria «esconder a sua vergonha», diferentemente da raposa de Esopo, que «começou a achar insuportável a vida».

A estrutura do texto de Esopo é pesada quando comparada à do texto de Tolstói. As frases de Esopo são entrecortadas, as de Tolstói não o são; o vocabulário de Tolstói é bem mais simples do que o de Esopo. Além disso, Tolstói resume todo o longo discurso narrativo de Esopo em uma única frase, dita pela própria raposa, artifício que proporciona mais «veracidade» e vida ao texto.

Concluindo:

Então uma delas interrompeu e disse: «Ô minha cara, só que se isso não lhe conviesse, você não nos faria tal proposta.» (Esopo)

Одна лисица и говорит: «Ох, не говорила бы ты этого, кабы не была куцая!» (Tolstói)

— Ah, você não diria isso se não estivesse estropiada. (Nossa tradução)

$\mathrm{Na}$ frase Одна лисииа и говорит: «Ох, не говорила бы ты этого, кабы не была куиая!», com o adjetivo куияая (estropiada), Tolstói recupera, em sua adaptação, um elemento do título da fábula de Esopo, ou seja, «A raposa cotó», ou «pitoca». Conforme já comentei, não há moral explícita nas adaptações de Tolstói.

Outro exemplo bastante ilustrativo do estilo límpido de Tolstói é o de seu vocabulário, sempre simples, e o de suas frases breves. Ao lado da versão de Tolstói, o texto de Esopo, considerado um fabulista de estilo leve, torna-se pesado. As observações acima adequam-se também aos exemplos que se seguem: 
$\underline{\text { A gralha e as pombas }}^{102}$

(Esopo)

Ao ver as pombas bem cuidadas em um pombal, uma gralha branqueou-se e foi tomar parte no regime delas. Enquanto esteve silenciosa, elas a aceitaram, crentes de que era uma pomba. Mas no exato momento em que se distraiu e soltou um grito, elas a enxotaram, pois estranharam sua voz. E ela, como lá não tivesse conseguido alimento, voltou outra vez para as gralhas. Mas estas não a reconheceram por causa da cor e barraram-na como companheira de refeição. Assim, ela, que tinha dois interesses, não alcançou nenhum.

Pois bem. Portanto, é preciso que também nós nos contentemos com o que temos, considerando que a ambição, além de não servir para nada, muitas vezes também dissipa as nossas posses.

\section{Галка и голуби}

(Tolstói)

Галка увидала, что голубей хорошо кормят, - выбелилась и влетела в голубятню. Голуби подумали сперва, что она такой же голубь, и пустили ее. Но галка забылась и закричала по-галчьи. Тогда ее голуби стали клевать и прогнали. Галка полетела назад к своим, но галки испугались ее оттого, что она была белая, и тоже прогнали.

\section{$\underline{\text { A gralha e os pombos }}{ }^{103}$ \\ (trad. M. A. B. P. Soares)}

Uma gralha viu que os pombos eram bem alimentados. Tingiu-se de branco e voou para o pombal. No princípio, os pombos pensaram que ela era um pombo, como eles, e a deixaram ficar. Mas a gralha se distraiu e grasnou como fazem as gralhas. Então, os pombos puseram-na para fora a bicadas. A gralha voou de volta para o seu bando, mas as outras gralhas se assustaram com a sua cor branca e também a expulsaram.

Charles Salomon demonstra surpresa pelo fato de que Tolstói jamais tenha alterado em nada o conteúdo de seus Livros de Leitura e aventa a possibilidade de eles serem suas obras preferidas. De fato, os textos dos Quatro Livros de Leitura

\footnotetext{
${ }^{102}$ Ibidem, p. 50.

${ }^{103}$ L.N. Tolstói. Contos da Nova Cartilha - Primeiro Livro de Leitura. (Trad. M. Aparecida B. P. Soares). São Paulo: Ateliê Editorial, 2005.
} 
estavam de acordo com a sua nova maneira de viver, diferentemente de Guerra e Paz ou Anna Karênina que, segundo o próprio escritor, "são obras escritas nos moldes da minha antiga maneira [de viver], maneira que hoje eu desaprovo."104

Ainda em seu prefácio, o tradutor francês registra um diálogo entre Tolstói e um de seus filhos:

$$
\begin{aligned}
& \text { — O que você está lendo? } \\
& \text { - A Sonata a Kreutzer. } \\
& \text { —Ah! Essa porcaria! }{ }^{105}
\end{aligned}
$$

${ }^{104}$ Idibem, p. LXI.

${ }^{105}$ Ibidem, p. LXII. 
CAPÍTULO II 
CAPÍTULO II

Contos da Nova Cartilha - Terceiro Livro de Leitura

\author{
Lev N. Tolstói
}




\section{ÍNDICE}

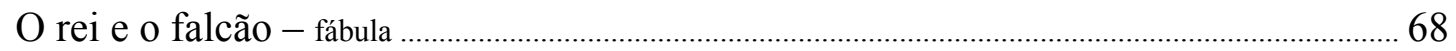

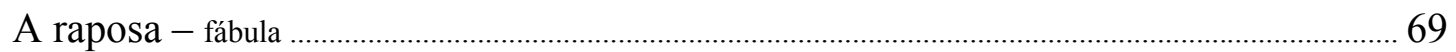

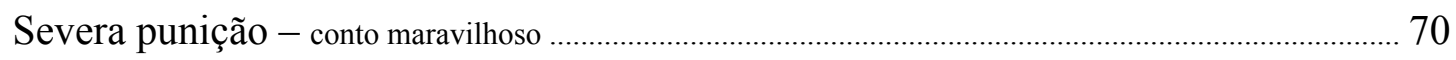

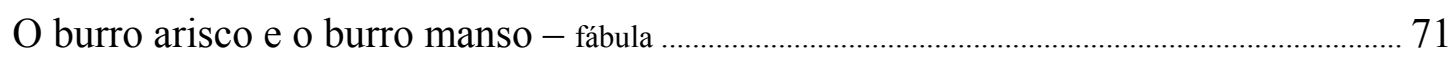

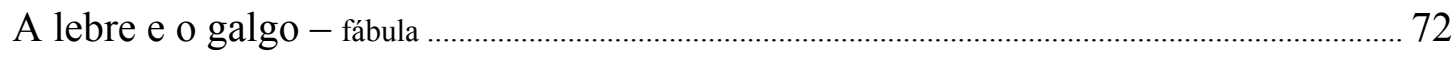

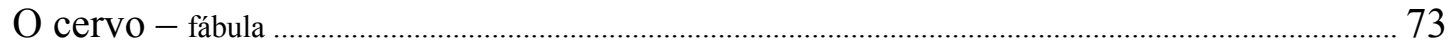

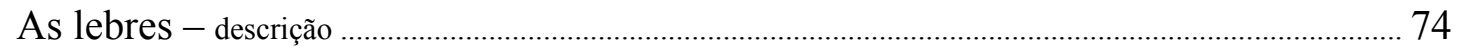

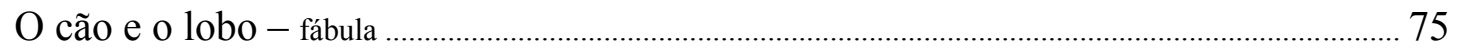

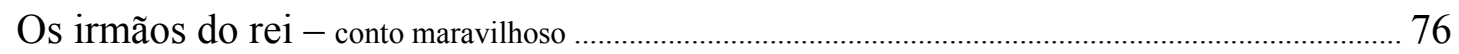

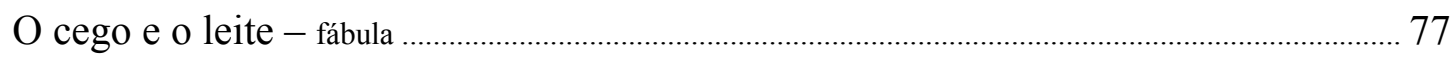

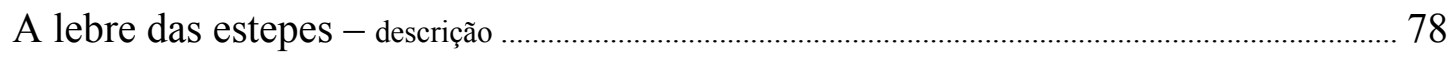

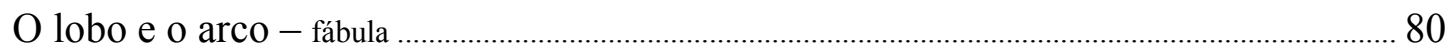

Como um mujique repartiu os gansos - conto maravilhoso................................................................. 81

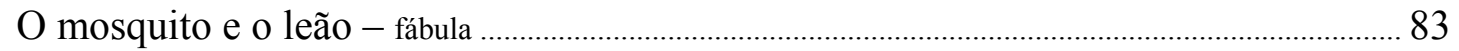

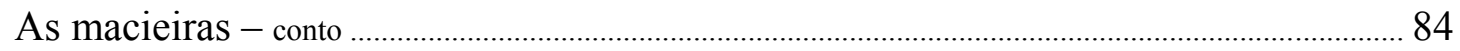

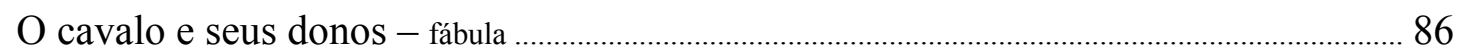

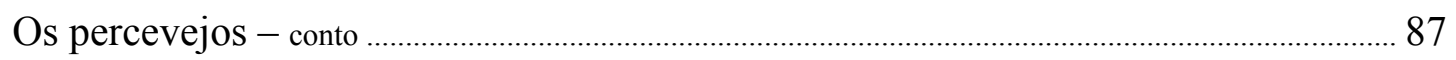

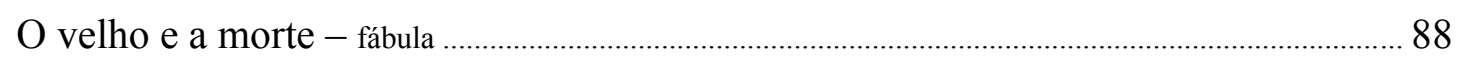

Como os gansos salvaram Roma - relato histórico ………………………………………………...... 89

Por que as árvores estalam no frio? - raciocínio ……………………………………………..... 90

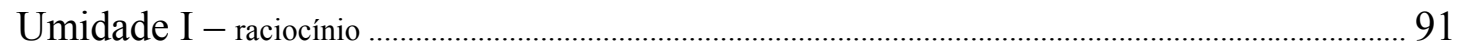

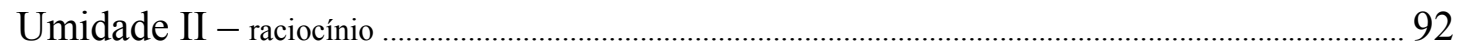

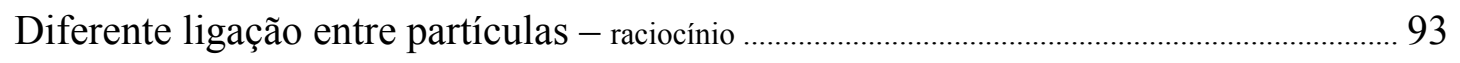

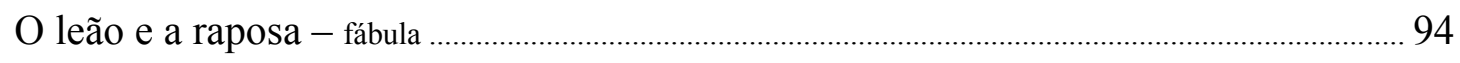

O juiz justo - conto maravilhoso ……………………………………………………………………….... 95

O cervo e o vinhedo - fábula ………………………………………………………………... 98

O filho do rei e seus companheiros - conto maravilhoso ………………………………………….... 99

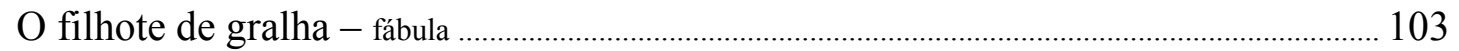

Como aprendi a cavalgar - relato de um senhor de terras ........................................................... 104

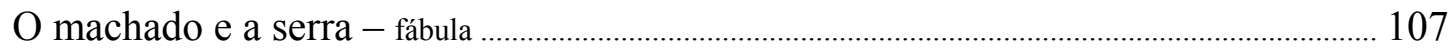




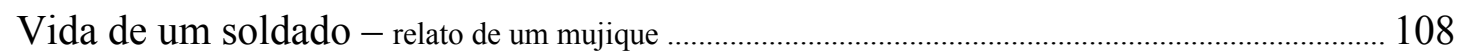

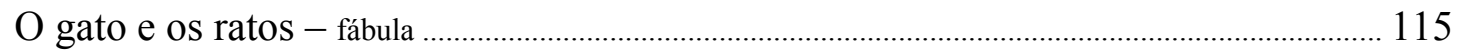

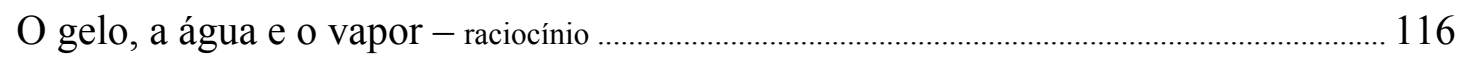

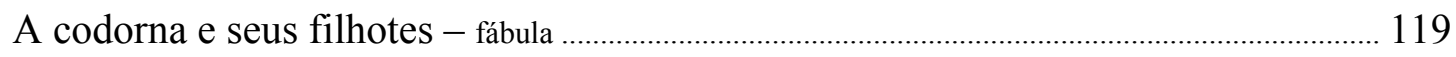

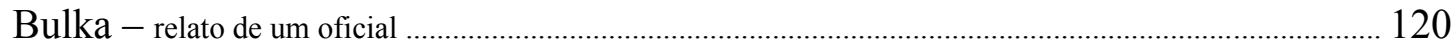

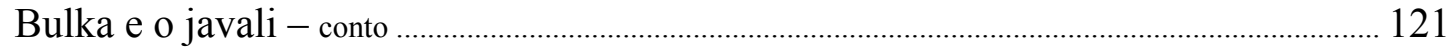

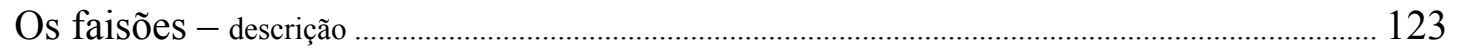

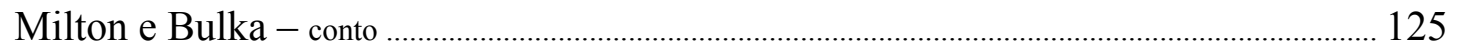

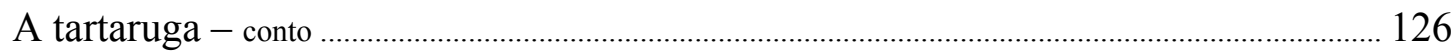

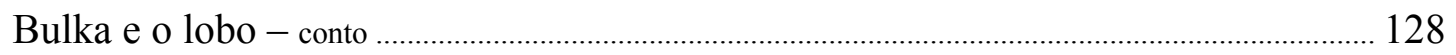

O que aconteceu com Bulka em Piatigorsk - conto .................................................................... 130

O fim de Bulka e de Milton - conto ................................................................................................... 133

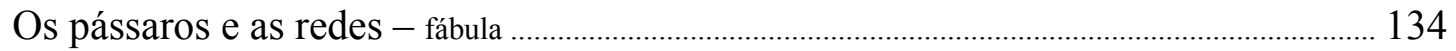

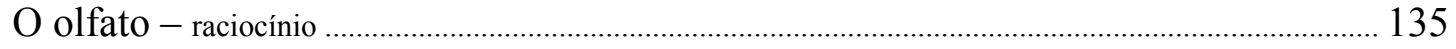

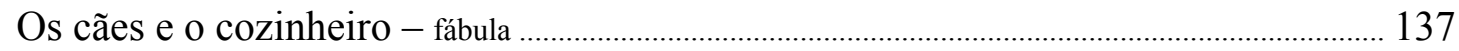

A fundação de Roma - relato histórico ………………………………………………………………..... 138

Deus diz a verdade, mas não a diz logo - história verdadeira ………………………………...... 140

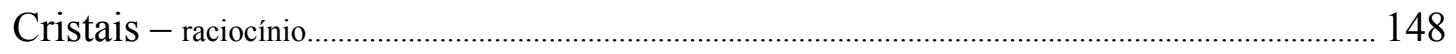

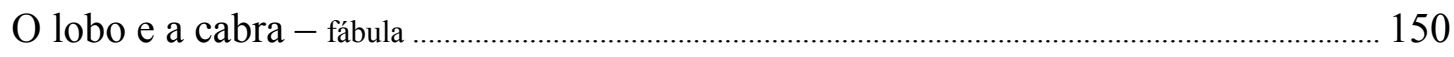

Polícrates de Samos - relato histórico ............................................................................................. 151 


\title{
Terceiro Livro de Leitura
}

\author{
O rei e o falcão \\ fábula
}

Durante uma caçada, um rei soltou o seu falcão preferido atrás de uma lebre e saiu a galope.

O falcão agarrou a lebre. O rei arrancou-lhe a lebre e começou a procurar água para matar a sede. Ele achou água numa vertente. Mas ela pingava gota a gota. Eis que o rei apanhou a caneca da sela e aproximou-a da água. A água apenas gotejava e, quando a caneca ficou cheia, o rei levou-a à boca para tentar bebê-la. De repente, o falcão teve um sobressalto no braço do rei, agitou as asas e derramou a água. $\mathrm{O}$ rei aproximou outra vez a caneca da água. Esperou bastante tempo até que a caneca ficasse cheia e, uma vez mais, quando ele ia levá-la à boca, o falcão sacudiu as asas e entornou a água.

Quando, pela terceira vez, o rei encheu a caneca e ia levá-la aos lábios, o falcão entornou-a de novo. $\mathrm{O}$ rei ficou bravo e, com toda a força, bateu o falcão numa pedra, matando-o. Então, os criados do rei chegaram e um deles subiu correndo até a fonte para conseguir mais água e encher logo a caneca. Mas o criado não levou água nenhuma, voltou com a caneca vazia e disse:

— Não se pode beber daquela água: há uma serpente na fonte e ela cuspiu o seu veneno nela. Felizmente o falcão entornou a água. Se tivesses tomado daquela água, estarias morto.

O rei disse:

— Paguei o bem com o mal ao me vingar do falcão: ele salvou a minha vida e eu o matei. 
A raposa

fábula

Uma raposa caiu numa armadilha, perdeu a sua cauda nela e fugiu. Então, começou a inventar um jeito de esconder a sua vergonha. Chamou as outras raposas e tentou convencê-las a cortarem suas caudas.

— A cauda — disse ela —, é totalmente inútil; não passa de um peso desnecessário que carregamos.

Então, uma raposa disse:

- Ah, você não diria isso se não estivesse estropiada.

A raposa estropiada calou a boca e foi-se embora. 


\section{Severa punição}

conto maravilhoso

Um homem foi ao mercado e comprou um pedaço de carne. No mercado, ludibriaram-no: deram-lhe um pedaço ruim de carne e, ainda, tapearam-no no peso.

Então, ele volta praguejando para casa, levando a carne. O tzar encontra-o e pergunta-lhe:

— Contra quem você está praguejando?

E ele responde:

- Contra aquele que me tapeou. Eu paguei por três libras, mas deram-me apenas duas, e, ainda por cima, essa carne ruim.

O tzar diz:

- Vamos voltar ao mercado; mostre-me aquele que o tapeou.

O homem voltou ao mercado e apontou o comerciante. A carne foi pesada na frente do tzar: com efeito, haviam-no tapeado realmente. Então, o tzar pergunta:

— Mas, como você quer que eu castigue o comerciante?

O homem responde:

- Ordene que cortem das costas dele o mesmo tanto de carne correspondente ao quanto fui tapeado.

O tzar, então, diz:

- Está bem, pegue uma faca e corte das costas do comerciante a libra de carne; mas, cuidado: que o peso seja exato. Se você cortar menos, ou mais, do que uma libra a culpa será sua.

O homem calou-se e foi para casa. 
$\mathrm{O}$ burro arisco e o burro manso

fábula

Um burro arisco viu um burro manso, aproximou-se dele e começou a elogiarlhe a vida: que liso era o seu corpo, e doce era o seu pasto. Depois, quando carregaram o burro manso, e quando o arreeiro começou a tocá-lo por trás, a pauladas, o burro arisco disse:

— Não, irmão, agora não o invejo mais: vejo que a sua vida custa-lhe suor. 
A lebre e o galgo ${ }^{106}$

fábula

Certa vez, uma lebre disse a um galgo:

- A troco de que você late quando corre atrás de nós? Você poderia nos pegar mais rapidamente se corresse calado. Mas, com o latido, você só nos leva para perto do caçador, ele percebe por onde corremos, corre com a espada atrás de nós, mata-nos e não lhe dá nada em troca.

O cachorro disse:

- Não é por isso que eu ladro. Ladro apenas porque, quando percebo o seu cheiro, fico louco de raiva e de alegria, pois sei que logo vou pegar você. Eu mesmo não sei por que, mas não consigo parar de latir.

\footnotetext{
${ }^{106}$ Cão lebréu. Uma das raças de cães que Tolstói usava para caçar. O galgo é bastante utilizado para caçar lebres, principalmente. É também um ótimo cão de companhia, e apega-se muito ao dono, sendo um animal tímido e dócil. (N.T.)
} 
O cervo

fábula

Um cervo foi a um riacho para matar a sede. Viu o seu reflexo na água e ficou orgulhoso de sua galhada: como ela havia crescido e esgalhado! Mas, olhou para as patas: "Mas minhas patas são franzinas e fracas". De repente, um leão saltou para agarrar o cervo. O cervo lançou-se a galope, chegou à floresta, enroscou sua galhada nos ramos e o leão agarrou-o. Então, quando chegou a sua hora de morrer, ele disse:

- Mas que tolo fui eu! Aquelas que eu acreditava serem franzinas e fracas salvaram-me, e aquela de que eu me orgulhava arruinou-me. 


\section{As lebres}

descrição

As lebres alimentam-se à noite. No inverno, as lebres das florestas alimentamse de cascas de árvores; as lebres dos campos, de grãos semeados no outono ${ }^{107}$ e de ervas; e as lebres que vivem perto dos celeiros, de grãos de cereais. À noite, elas abrem caminho sobre a neve, deixando um rastro profundo e visível. Os caçadores de lebres são pessoas, cães, lobos, raposas, gralhas machos e gralhas fêmeas. Se a lebre andasse simplesmente reto, logo de manhã nós encontraríamos o seu rastro e a pegaríamos, mas Deus concedeu covardia à lebre, e é a covardia que a salva.

À noite, a lebre anda sem medo pelos campos e florestas, e deixa rastros em linha reta; mas, assim que amanhece, seus inimigos despertam: a lebre começa a ouvir ora os latidos dos cães, ora o guincho dos trenós, ora as vozes dos mujiques, ora o barulho dos lobos na floresta. Então, de medo, ela começa a ziguezaguear de um lado para outro. Sai pulando em frente, assusta-se com qualquer coisa e volta correndo, seguindo o seu rastro. Ouve outro barulho, salta rapidamente para o lado e, pulando, afasta-se de seu próprio rastro. De novo a lebre ouve algum barulho, de novo gira e, de novo, pula para o lado. Quando amanhece, ela vai se deitar.

$\mathrm{Na}$ manhã seguinte, os caçadores tentam encontrar os rastros da lebre, confundem-se em meio aos rastros duplos e aos saltos longos, e surpreendem-se com a astúcia dela. Mas a lebre nem pensa em enganá-los. Ela só tem medo de tudo.

\footnotetext{
${ }^{107} \mathrm{Na}$ Rússia, os cereais são semeados no outono, passam o inverno sob a neve, brotam na primavera e são colhidos no verão. (N.T.)
} 
O cão e o lobo

fabula

Um cão dormiu fora do quintal. Um lobo faminto apareceu e sentiu vontade de comê-lo. O cão, então, disse:

— Lobo! Espere até que eu coma; agora estou pele e osso. Ouça: dê-me um prazo, os patrões vão festejar um casamento, vou me empanturrar de comida, vou engordar e, então, será bem melhor me comer.

O lobo acreditou e foi embora. Ei-lo que volta outra vez e vê o cão dormindo no telhado. O lobo, então, pergunta:

- $\mathrm{O}$ casamento já acabou?

E o cão responde:

- Quer saber, lobo? Caso você me encontre outra vez dormindo na frente do portão, não espere mais casamento nenhum. 
Os irmãos do rei

conto maravilhoso

Um rei estava andando pela rua. Um mendigo aproximou-se dele e começou a lhe pedir esmola.

$\mathrm{O}$ rei nada deu. $\mathrm{O}$ mendigo disse:

— Rei, percebe-se que você se esqueceu de que Deus é o pai de todos nós; somos todos irmãos e precisamos repartir tudo.

Então, o rei parou e disse:

- Você está certo, somos irmãos e precisamos repartir.

E o rei deu uma moeda de ouro ao mendigo. O mendigo pegou a moeda de ouro e disse:

— Você deu pouco; como é possível repartir assim com os irmãos? É preciso repartir em partes iguais. Você tem um milhão de moedas e deu-me apenas uma.

Então, o rei respondeu:

— É verdade, tenho um milhão de moedas e dei-lhe uma delas; mas é que tenho tantos irmãos quantas são as moedas que tenho. 
O cego e o leite

fábula

Um cego de nascença perguntou a um vidente:

— De que cor é o leite?

$\mathrm{O}$ vidente respondeu:

- A cor do leite é a mesma cor do papel branco.

O cego perguntou:

- Quer dizer que essa cor faz o mesmo frufru nas mãos que o papel?

$\mathrm{O}$ vidente respondeu:

— Não, ela é branca como a farinha branca.

O cego perguntou:

— Quer dizer que ela é fofa e seca como a farinha?

$\mathrm{O}$ vidente respondeu:

— Não, ela só é branca como uma lebre branca.

O cego perguntou:

— Então, quer dizer que ela é felpuda e macia como uma lebre?

$\mathrm{O}$ vidente respondeu:

— Não, a cor branca é exatamente como a neve.

O cego perguntou:

- Ah, quer dizer que ela é fria como a neve?

E, por mais exemplos que o vidente desse, o cego não conseguia entender como era a cor branca do leite. 
A lebre das estepes

descrição

Era inverno, e uma lebre das estepes vivia nas cercanias de uma aldeia. Quando amanheceu, ela levantou uma orelha e pôs-se a escutar; depois, levantou a outra orelha, remexeu os bigodes, farejou e sentou-se sobre as patas traseiras. Depois, saltou vez ou outra sobre a neve funda, sentou-se de novo sobre as patas traseiras, e começou a sondar. À sua volta, nada se via, exceto neve. As ondas de neve no chão brilhavam como açúcar. Sobre a cabeça da lebre pairava uma névoa fina e, através dessa névoa, destacavam-se grandes estrelas brilhantes.

Para chegar até a conhecida tulha, a lebre teve de atravessar uma estrada. Naquela grande estrada ouviam-se o chio dos patins dos trenós, os relinchos dos cavalos e o rangido dos bancos dos trenós.

Ao chegar perto da estrada, a lebre parou de novo. Os mujiques andavam ao lado dos trenós com as golas de seus cafetãs levantadas. Mal se viam seus rostos. Suas barbas, bigodes e pestanas estavam brancos. Uma névoa saía de suas bocas e narinas. Seus cavalos estavam suados e, devido ao suor, a geada grudava nos pelos. Os cavalos batiam as cabeças contra as coleiras, afundavam e saíam dos buracos da estrada. Os mujiques alcançavam, ultrapassavam e chicoteavam os cavalos. Dois velhinhos seguiam conversando e, um deles, contava ao outro como haviam the roubado um cavalo.

Quando o comboio passou, a lebre pulou para o outro lado da estrada e, devagarzinho, aproximou-se da tulha. Um cachorrinho do comboio viu a lebre. Ele latiu e começou a persegui-la. A lebre começou a saltar entre os montículos de neve, em direção da tulha. Ela passava facilmente por entre os montículos de neve; mas, no décimo salto, o cachorro afundou na neve e parou. Então, a lebre também parou, sentou-se sobre as patas traseiras e, lentamente, dirigiu-se à tulha. No caminho, encontrou duas lebres num pasto verde. Elas comiam e brincavam. A lebre brincou um pouco com suas companheiras; juntas, revolveram a neve gelada, a lebre comeu os brotinhos e seguiu adiante. A aldeia estava totalmente silenciosa e às escuras. Ouviam-se apenas o choro de uma criança atrás das paredes de uma isbá e o estalido do gelo no madeiramento das outras isbás. A lebre chegou à tulha e lá encontrou suas companheiras. Brincou com elas no galpão de debulha, comeu aveia de um saco já 
aberto, subiu até o telhado coberto de neve, foi até a estufa para feixes, passou pela cerca, e voltou para a sua toca. No Leste, a aurora brilhava, as estrelas começavam a desaparecer e uma cortina de névoa fria erguia-se da terra. $\mathrm{Na}$ aldeia perto dali as camponesas acordavam e saíam para buscar água; os mujiques levavam feno para o gado, as crianças gritavam e choravam. Na estrada havia mais trenós do que antes, e os mujiques conversavam ainda mais alto. A lebre deu um pulo, cruzou a estrada, foi para a sua velha toca, escolheu um lugarzinho mais alto, cavou a neve, entrou de costas e adormeceu de olhos abertos. 
O lobo e o arco

fábula

Um caçador saiu para caçar com arco e flecha, matou uma cabra, jogou-a sobre as costas e carregou-a. No caminho, ele viu um javali. O caçador jogou a cabra no chão, atirou contra o javali e feriu-o. $\mathrm{O}$ javali lançou-se sobre o caçador, rasgou-o até matá-lo e, ele próprio, também morreu. Um lobo farejou o sangue, e foi até o lugar onde estavam a cabra, o javali, o homem e seu arco. O lobo ficou alegre e pensou: agora, vou me fartar por muito tempo; basta não comer tudo de uma só vez, vou aos poucos para que nada se perca. Primeiro, comerei o mais duro e, depois, degustarei os pedaços mais tenros e mais saborosos.

O lobo cheirou a cabra, o javali, o homem, e disse:

- Esta é uma iguaria macia, vou comê-la depois; primeiro, deixe-me comer esses tendões que estão no arco. E ele começou a abocanhar os tendões sobre o arco. Quando ele mordeu a corda, o arco abriu-se e bateu na barriga do lobo. O lobo espichou as canelas ali mesmo, e outros lobos comeram o homem, a cabra, o javali e o lobo. 
Como um mujique repartiu os gansos

conto maravilhoso

Um mujique pobre ficou sem farinha. Então, ele pensou em pedir farinha para o seu senhor ${ }^{108}$. Para não ir de mãos vazias, pegou um ganso, assou-o e saiu. O senhor aceitou o ganso e disse ao mujique:

- Obrigado, mujique, pelo ganso; mas eu não sei como nós vamos reparti-lo. É que eu tenho mulher, dois filhos e duas filhas. Como vamos repartir o ganso sem magoar ninguém?

O mujique disse:

- Eu reparto.

Ele pegou uma faca, cortou a cabeça do ganso e disse ao seu senhor:

— Você é o cabeça da família. Para você, a cabeça.

Depois, cortou o traseiro do ganso e deu-o à senhora:

— Você — disse ele — , fica em casa e cuida da casa. Para você, o traseiro.

Depois, cortou as patas do ganso e deu-as aos filhos:

- Para vocês — disse ele — , as patas: vocês devem trilhar o caminho de vosso pai.

E, para as filhas, ele deu as asas:

— Vocês — disse ele — , logo voarão de casa; fiquem com as asinhas. E, com as sobras, fico eu!

E o mujique pegou todo o ganso para si.

O senhor riu, deu farinha e dinheiro ao mujique.

Um mujique rico ouvira dizer que o senhor havia dado farinha e dinheiro a um mujique pobre em troca de um ganso. Ele assou cinco gansos e levou-os àquele mesmo senhor.

O senhor disse:

- Obrigado pelos gansos. Mas é que eu tenho mulher, dois filhos e duas filhas; juntos, somamos seis. Como poderíamos repartir os gansos sem ofender ninguém?

O mujique rico pôs-se a refletir, mas não encontrou solução.

\footnotetext{
${ }^{108}$ Na Rússia, o regime de servidão vigorou até 1861. (N.T.)
} 
$\mathrm{O}$ senhor mandou chamar o mujique pobre e mandou-o repartir os gansos. $\mathrm{O}$ mujique pobre pegou um ganso, deu-o ao senhor e à senhora e disse:

— Pronto: com o ganso, são três.

Deu outro aos filhos:

— Pronto —, disse ele. Três.

Deu outro às filhas:

— Pronto: três também.

E pegou dois gansos para si.

— Pronto — disse ele. E, com os gansos, somos três. Assim está justo.

O senhor riu, deu mais dinheiro e mais farinha ao mujique pobre e mandou o mujique rico embora. 
O mosquito e o leão

fábula

Um mosquito voou até um leão e disse:

— Você pensa que é mais forte do que eu? Engano! Que força você tem? Arranhar com as garras e dar dentadas com os dentes são coisas que até as mulheres fazem com os mujiques. Eu sou mais forte do que você; se quiser, podemos guerrear!

O mosquito soou a trombeta e começou a morder as bochechas carecas e o nariz do leão. O leão começou a bater-se no focinho e a rasgar-se com as garras; feriu todo o focinho até sangrar e caiu sem forças.

O mosquito tocou a trombeta com alegria e voou. Depois, enrolou-se numa teia de aranha, e a aranha começou a chupar o seu sangue. Então, o mosquito disse:

- Venci o leão, uma fera forte, e eis que sou vítima de uma reles aranha. 


\section{As macieiras}

conto

$\mathrm{Eu}$ plantei duzentas mudas de macieiras e, durante três anos, na primavera e no outono, afofei a terra ao redor delas; no inverno, envolvi-as em palha para protegêlas das lebres. No quarto ano, quando a neve derreteu, fui ver as macieiras. Elas haviam se desenvolvido no inverno: suas cascas brilhavam e elas pareciam cheias de seiva; todos os raminhos estavam inteiros e, em cada pontinha e forquilha, havia pequenos botões floridos e redondos como ervilhas. Em certos lugares os botões já haviam desabrochado e via-se o escarlate nas bordas das pétalas. Eu sabia que todos os brotinhos tornar-se-iam flores e frutos, e fiquei feliz ao ver as minhas macieiras. Mas quando desembrulhei a primeira delas, vi que embaixo, bem perto da terra, a casca da árvore estava toda roída em volta, bem no lenho, como um anel branco. Aquilo era obra dos camundongos. Desembrulhei outra macieira e ela estava igual. De duzentas macieiras, nem uma estava intacta. Besuntei os lugares roídos com resina e cera, mas quando elas desabrocharam, suas flores logo caíram. Saíram pequenas folhas, mas murcharam e secaram. A casca enrugou e ficou preta. De duzentas macieiras, sobraram apenas nove. A casca dessas nove macieiras não havia sido roída até o fim: no anel branco restava ainda uma pequena faixa circular de casca. Naquelas faixas, onde a casca abria-se, formaram-se protuberâncias e, mesmo doentes, as macieiras vingaram. As demais pereceram; apenas aquelas que haviam sido roídas na parte inferior brotaram, mas eram macieiras selvagens.

Para as árvores, a casca é o mesmo que as veias são para o homem: pelas veias o sangue circula no homem e, pela casca, a seiva circula na árvore, chegando até os ramos, as folhas e as flores. Pode-se ocar todo o interior de uma árvore - existem velhos salgueiros assim. Para a árvore viver é preciso apenas que a casca esteja viva; mas, se a casca perecer, a árvore também perecerá. Se cortarmos as veias de um homem, ele morrerá: primeiro, porque o sangue derramar-se-á, e, segundo, porque o sangue não mais circulará pelo corpo.

Assim, a bétula seca quando as crianças abrem um buraco nela para beber a sua seiva, pois toda a seiva da árvore é derramada. 
Assim, as macieiras feneceram porque os camundongos roeram toda a circunferência da casca e a seiva não pôde mais circular das raízes para os ramos, para as folhas e para as flores. 
O cavalo e seus donos

fábula

Um jardineiro tinha um cavalo que tinha muito trabalho e pouca comida. Então, o cavalo começou a implorar a Deus para ir para outro patrão. E assim foi feito. O jardineiro vendeu o cavalo a um oleiro. O cavalo ficou feliz, mas, com o oleiro, ele tinha ainda mais trabalho do que antes. E, outra vez, o cavalo queixou-se de sua sina e implorou ir para um dono melhor. E isso aconteceu. O oleiro vendeu o cavalo a um curtidor. Mas eis que, quando viu peles de cavalos no pátio do curtume, o cavalo começou a gemer, lamentando-se: “Oh, que desgraça, pobre de mim. Melhor teria sido ficar com os donos antigos: agora vejo que me venderam não para o trabalho, mas por causa do meu couro". 
Os percevejos

conto

Eu havia parado na estrada para pernoitar numa hospedaria. Antes de me deitar, peguei uma vela, olhei os cantos da cama e das paredes e, quando vi que havia percevejos em todos os cantos, comecei a imaginar um jeito de me acomodar durante a noite de modo que eles não me alcançassem.

Eu tinha uma cama dobrável e sabia que, se a colocasse no centro do quarto, os percevejos desceriam da parede para o chão e, do chão, chegariam até mim pelos pés da cama; por isso, pedi ao proprietário quatro bacias de madeira, enchi-as de água e coloquei cada pé da cama dentro de cada bacia com água. Deitei-me, pus a vela no chão, e fiquei olhando o que os percevejos fariam. Havia muitos deles e eles já tinham me farejado: vi como arrastavam-se no chão, subiam na beirada da bacia, alguns caíam na água e outros davam meia volta. "Fui mais esperto do que eles", pensei eu. Agora não me alcançarão. E já ia pegar a vela quando, de repente, senti que alguma coisa me picava. Olhei ao redor: um percevejo. Como ele tinha ido parar em mim? Menos de um minuto depois, achei outro. Olhei para os lados, tentando saber como eles tinham me alcançado.

Durante muito tempo, não consegui descobrir, mas, finalmente, bati os olhos no teto e vi um percevejo andando; assim que ele chegou bem acima da cama, desgrudou do teto e pulou sobre mim. "Não — pensei eu — vocês são mais astutos". Peguei meu casaco de pele e fui para fora. 
O velho e a morte

fábula

Certa vez um velho rachou lenha e começou a carregá-la nas costas. O caminho era longo. Ele ficou exausto, pôs o feixe no chão e disse:

- Ah, bem que a morte podia chegar!

A morte chegou e disse:

- Aqui estou. O que você quer?

O velho assustou-se e respondeu:

- Quero que você me ajude a erguer o feixe. 


\section{Como os gansos salvaram Roma}

relato histórico

No ano 390 a. C., gauleses selvagens atacaram os romanos. Os romanos não podiam vencê-los; alguns fugiram, para sempre, da cidade e, outros, trancaram-se na fortaleza. Essa fortaleza chama-se capitólio. Apenas os senadores permaneceram na cidade. Os gauleses invadiram a cidade, mataram todos os senadores e incendiaram Roma. No centro de Roma restou apenas o capitólio, onde eles não conseguiram entrar. Os gauleses queriam saquear o capitólio, pois sabiam que ali havia grande riqueza. O capitólio, no entanto, ficava sobre uma colina íngreme: de um lado, havia muralhas e o portão, do outro lado, um despenhadeiro também íngreme. À noite, os gauleses começaram a escalar a colina do capitólio às escondidas: subiam um nos ombros do outro, e passavam, um ao outro, as lanças e os gládios.

Chegaram ao topo do despenhadeiro sem serem notados; nem um cão os viu.

Eles já haviam começado a pular as muralhas quando, de repente, foram percebidos por gansos que, grasnando, agitavam as asas. Um romano acordou, lançou-se contra as muralhas e derrubou um gaulês despenhadeiro abaixo. O gaulês caiu, levando outros consigo. Então, os romanos acorreram e começaram a atirar paus e pedras para baixo, matando muitos gauleses. Depois, Roma foi socorrida e, os gauleses, expulsos.

Desde então, para lembrar esse dia, os romanos passaram a festejá-lo. Sacerdotes caminhavam paramentados pela cidade; um deles levava um ganso e, atrás deles, ia um cachorro preso a uma corda. E, aproximando-se, o povo saudava o ganso e o sacerdote: ao ganso, davam oferendas, e batiam com paus no cão até ele morrer. 
Por que as árvores estalam no frio?

raciocínio

Porque as árvores contêm umidade, e a umidade congela com a água. Quando congela, a água dilata-se; e quando não encontra espaço para se dilatar, ela trinca as árvores.

Se enchermos uma garrafa com água e deixarmos essa garrafa no frio, a água congelará e estourará a garrafa.

Quando a água se transforma em gelo, esse gelo adquire tamanha força que, se enchermos um canhão de ferro com água e o congelarmos, ele explodirá por causa do gelo. ${ }^{109}$

Por que, ao contrário do ferro, a água não se contrai com o frio, mas dilata-se quando congelada?

Porque, quando a água congela, suas partículas unem-se de maneira diferente, e o espaço entre elas aumenta.

Por que a água não se contrai ao congelar?

Porque a água dos rios e lagos não se congela até o fundo.

O gelo dilata-se com o frio, torna-se mais leve do que a água e boia sobre ela. Apenas a água mais profunda congela um pouco e torna-se mais e mais espessa, mas ela nunca congela até o fundo.

Mas, se a água se contraísse com o frio, assim como o ferro se contrai, a água da superfície do rio ficaria congelada e afundaria, porque o gelo ficaria mais pesado do que ela.

Depois, se a água da superfície congelasse novamente e afundasse, as águas dos lagos e dos rios congelar-se-iam do fundo até a superfície.

${ }^{109} \mathrm{Na}$ Rússia, durante o inverno, os canhões devem permanecer com a boca virada para baixo justamente para evitar que a água da chuva entre neles, acumule-se e congele-se. (N.T.) 


\section{Umidade I}

raciocínio

Por que, algumas vezes, a aranha tece sua teia e permanece bem no meio do seu ninho e, outras vezes, sai do ninho e começa a tecer outra teia?

A aranha tece a teia de acordo com o tempo que faz e com o tempo que fará. Se observarmos uma teia de aranha, é possível saber que tempo fará: se a aranha permanecer retraída no centro da teia e não sair dela, significa que vai chover. Se ela sair do ninho e fizer uma nova teia, quer dizer que o tempo vai ser bom.

Como pode a aranha saber, de antemão, que tempo fará?

Os sentidos da aranha são tão aguçados que, quando a umidade do ar mal começa a se formar, quando sequer conseguimos percebê-la, e quando, para nós o dia ainda está claro, para a aranha o dia já está chuvoso.

Do mesmo modo como uma pessoa mal agasalhada sente logo a umidade, e outra pessoa bem agasalhada não a percebe, também para a aranha pode já estar chovendo, ao passo que, para nós, a chuva apenas está para cair. 


\section{Umidade II}

raciocínio

Por que, no outono e no inverno, as portas dilatam-se e não fecham e, no verão, elas contraem-se e fecham?

Porque no outono e no inverno a madeira absorve a água tal uma esponja e, no verão, a água evapora, encolhendo a madeira.

Por que uma árvore frágil como o álamo dilata-se mais do que o carvalho?

Porque árvores resistentes como o carvalho têm menos espaços ocos, e a água não tem onde se acumular, e porque árvores frágeis como o álamo têm mais espaços ocos, e a água tem onde se acumular. Árvores podres possuem ainda mais espaços ocos, e é por isso que elas ficam encharcadas e envergam.

As colmeias de abelhas são feitas com a mais fraca e com a mais podre das madeiras: as melhores colmeias são feitas com os mais podres salgueiros. Por quê?

Porque o ar circula através de um tronco podre e, para as abelhas, o ar de uma colmeia feita com essa madeira é mais leve.

Por que tábuas úmidas empenam?

Porque elas secam de maneira desigual. Se colocarmos uma tábua úmida num canto da piétchka ${ }^{110}$, a água evaporará, a madeira secará de um lado e envergará do outro. O lado úmido não poderá se contrair porque há água nele e, assim, toda a madeira empenará.

Para que o assoalho não empene, é preciso cortar tabuinhas secas em pequenos pedaços e mergulhá-los em água fervente. Depois que toda a água tiver evaporado deles, devemos colá-los e, assim, eles não empenarão mais.

\footnotetext{
${ }^{110}$ Forno-fogão. Além de ser usada para cozinhar e assar, a piétchka também aquece a isbá. Nela secam-se roupas, e suas bancadas servem de cama no inverno. (N.T.)
} 
Diferente ligação entre partículas

raciocínio

Por que os coxins e os cubos das rodas que ficam embaixo das telegas são feitos com carvalho e não com bétula? Os coxins e os cubos das rodas devem ser resistentes, e o carvalho não é mais caro do que a bétula ${ }^{111}$.

Porque o carvalho parte-se no sentido do comprimento, e a bétula não se parte, mas se desfaz toda em fibras.

Então, apesar de ser mais forte do que a bétula, o carvalho pode ser rachado de tal forma que ele se parte no comprimento, e isso não acontece com a bétula.

Por que envergamos as rodas dos patins dos trenós, feitas com carvalho e olmo, e não envergamos aquelas feitas com bétula e tília?

Porque, quando aquecemos o carvalho e o olmo no vapor, eles envergam-se e não se quebram, mas a bétula e a tília desfazem-se em fibras. Tudo isso porque, no carvalho e na bétula, as partículas da madeira unem-se de maneira diferente.

${ }^{111}$ A madeira do carvalho é mais resistente do que a madeira da bétula. (N.T.) 


\section{O leão e a raposa}

fábula

De velhice, um leão não podia mais caçar e imaginou um meio de viver com astúcia: entrou numa caverna, deitou-se e fingiu estar doente. Animais começaram a visitá-lo e ele comia aqueles que, para vê-lo, entravam em sua caverna. Uma raposa percebeu o que acontecia, parou à entrada da caverna e disse:

— E então, leão, como vai?

O leão respondeu:

— Mal. Mas por que é que você não entra?

E a raposa disse:

- Não entro porque, pelos rastros, vejo que há muitas entradas e nenhuma saída. 
Báuakas, um rei argelino, resolveu descobrir, ele próprio, se era verdade o que lhe haviam contado: numa de suas cidades havia um juiz justo que reconhecia a verdade imediatamente, e de quem sequer um velhaco conseguia se safar. Báuakas disfarçou-se de mercador e foi, montado em seu cavalo, até a cidade onde vivia o juiz. À entrada da cidade, um aleijado aproximou-se dele, e começou a the pedir esmola. Báuakas deu-lhe algumas moedas e tentou seguir adiante, mas o aleijado agarrou-se à sua roupa.

— O que você quer? - perguntou Báuakas. Eu já não lhe dei esmola?

— Esmola você deu — disse o aleijado —, mas conceda-me uma graça: leveme em seu cavalo até a praça, pois os cavalos e camelos podem me atropelar.

Báuakas acomodou o aleijado atrás de si e levou-o até a praça. Na praça, Báuakas parou o cavalo. Mas o mendigo não desceu. Báuakas disse:

— O que você está esperando? Desça, já chegamos.

Mas o mendigo respondeu:

- Descer para quê? O cavalo é meu e, se você não quiser entregá-lo de bom grado, iremos até o juiz. As pessoas juntaram-se ao redor deles e escutaram toda a discussão. Todos gritavam:

— Vão até o juiz, ele decidirá.

Báuakas e o mendigo foram até o juiz. O tribunal estava cheio de gente e o juiz chamava os réus, um por vez. Antes de chegar a vez de Báuakas, o juiz chamou um sábio e um mujique: o motivo do julgamento era uma esposa. O mujique dizia que a esposa era sua, e o sábio dizia que ela era sua esposa. O juiz ouviu os dois, pensou e disse:

— Deixem a mulher aqui comigo e voltem amanhã.

Quando eles saíram, entraram um açougueiro e um vendedor de óleo. O açougueiro estava coberto de sangue e, o vendedor de óleo, cheio de óleo. O açougueiro segurava dinheiro na mão e o vendedor de óleo segurava o açougueiro pela mão. $\mathrm{O}$ açougueiro disse: 
— Eu comprei óleo deste homem, peguei a carteira para pagar e ele agarroume pelo braço, querendo toda a carteira. Por isso viemos vê-lo: eu, com a carteira na mão, e ele, segurando-me pela mão. Mas o dinheiro é meu e ele é um ladrão.

E o vendedor de óleo disse:

- É mentira. O açougueiro procurou-me para comprar óleo. Quando enchilhe um cântaro, ele pediu-me que lhe trocasse uma moeda de ouro. Peguei o dinheiro e coloquei-o sobre o balcão. Mas ele agarrou-o e tentou correr. Segurei-o pela mão e trouxe-o até aqui.

Depois de um tempo, o juiz disse:

— Deixem o dinheiro aqui e voltem amanhã.

Quando chegou a vez de Báuakas e do mendigo, Báuakas contou como tudo acontecera. O juiz ouviu-o e perguntou ao mendigo. O mendigo disse:

— É tudo mentira. Eu estava indo a cavalo pela cidade, ele estava sentado no chão e pediu-me para levá-lo comigo. Coloquei-o sobre o cavalo e levei-o até onde ele precisava ir. Mas ele não quis descer e disse que o cavalo era dele. É mentira.

O juiz pensou e disse:

- Deixem o cavalo aqui comigo e voltem amanhã.

No dia seguinte, juntou-se um grande número de gente para ouvir a sentença do juiz.

Primeiro, aproximaram-se o sábio e o mujique.

— Pegue a sua esposa - disse o juiz ao sábio — , e deem cinquenta pauladas no mujique.

O sábio pegou sua esposa e o mujique foi castigado ali mesmo.

Depois, o juiz chamou o açougueiro:

— O dinheiro é seu —, disse-lhe ele.

Depois, apontou para o vendedor de óleo e disse:

— Deem-lhe cinquenta pauladas.

Então, chamaram Báuakas e o aleijado.

— Você reconheceria o seu cavalo dentre outros vinte? - perguntou o juiz a Báuakas.

— Reconheceria.

- E você?

— Eu também reconheceria — disse o aleijado.

— Siga-me — disse o juiz a Báuakas. 
Eles foram à estrebaria. Dentre outros vinte cavalos, Báuakas mostrou imediatamente o seu cavalo. Depois, o juiz mandou chamar o aleijado à estrebaria e também o mandou apontar o cavalo. O aleijado reconheceu o cavalo e mostrou-o ao juiz. Então, o juiz sentou-se em seu lugar e disse a Báuakas:

- O cavalo é seu. Leve-o. E ao aleijado deem cinquenta pauladas.

Depois do julgamento o juiz foi para casa e Báuakas seguiu-o.

— O que você quer? Por acaso não está satisfeito com a minha decisão? perguntou o juiz.

— Sim, estou satisfeito - respondeu Báuakas. Eu gostaria apenas de saber como você descobriu que a esposa pertencia ao sábio, e não ao mujique; que o dinheiro pertencia ao açougueiro, e não ao vendedor de óleo; e que o cavalo pertencia a mim, e não ao mendigo.

— No caso da mulher, fiz o seguinte: chamei-a de manhã e disse-lhe: encha de tinta o meu tinteiro. Ela pegou o tinteiro, lavou-o rapidamente e, com destreza, encheu-o de tinta. Portanto, ela estava acostumada àquilo. Fosse ela a esposa de um mujique, não saberia fazer aquilo. Quer dizer que o sábio estava certo. No caso do dinheiro, fiz o seguinte: coloquei o dinheiro numa xícara com água e, hoje cedo, olhei para ver se havia óleo na superfície da água. Se o dinheiro fosse do vendedor de óleo, ele estaria sujo de suas mãos oleosas. $\mathrm{Na}$ água não havia óleo. Quer dizer que o açougueiro falava a verdade.

No caso do cavalo foi mais difícil descobrir. Como você, também o aleijado apontou o cavalo dentre outros vinte cavalos. Mas se eu os levei, os dois, à estrebaria, não foi para ver se vocês reconheceriam o cavalo, mas para ver qual de vocês dois o cavalo reconheceria. Quando você se aproximou dele, ele virou a cabeça na sua direção; mas quando o aleijado tocou nele, ele abaixou as orelhas e ergueu uma pata. Por isso eu soube que você era o verdadeiro dono do cavalo.

Então, Báuakas disse:

- Não sou um mercador, mas o rei Báuakas. Vim até aqui para ver se era verdade o que falavam sobre você. Agora vejo que você é um juiz sábio. Peça-me o que quiser, e eu gratificar-lhe-ei.

O juiz respondeu:

— Não preciso de gratificações. Sinto-me já feliz por receber elogios de meu rei. 
O cervo e o vinhedo

fábula

Um cervo escondeu-se dos caçadores no meio de um vinhedo. Depois que os caçadores passaram por ele, o cervo começou a comer as folhas das videiras.

Os caçadores notaram que as folhas moviam-se e pensaram: será que não há algum animal embaixo das folhas?" Atiraram e feriram o cervo.

Morrendo, o cervo disse:

- Bem feito para mim por querer comer as folhas, justamente aquelas que já haviam me salvado. 
O filho do rei e seus companheiros

conto maravilhoso

Um rei tinha dois filhos. Ele amava o mais velho e deu-lhe todo o seu reino. A mãe sentia pena do filho mais novo e discutia com o seu marido. $\mathrm{O}$ rei zangava-se com ela e, todos os dias, um brigava com o outro. Então, o príncipe pensou: “o melhor para mim será ir para outro lugar qualquer". Despediu-se do pai e da mãe, vestiu-se com roupas simples e saiu para correr o mundo.

No caminho, ele encontrou um mercador. O mercador contou-lhe que, antes, ele fora rico, mas que toda a sua mercadoria havia afundado no mar, e que, então, ele estava indo procurar a felicidade em outras terras.

Ambos seguiram juntos. No terceiro dia, a eles juntou-se um companheiro. Conversa vai, conversa vem, o novo companheiro contou-lhes que era um camponês, que tivera casa e terra mas que, com a guerra, seus campos haviam sido destruídos e, o seu quintal, queimado. Diante disso, nada lhe sobrara para viver e, então, ele estava indo procurar trabalho em outras terras.

Eles seguiram todos juntos. Chegaram a uma grande cidade e sentaram-se para descansar. Eis que o camponês, então, disse:

- Bem, meus irmãos, basta de tanto vadiar. Agora que chegamos a uma cidade, precisamos começar a procurar trabalho, cada qual em seu ofício.

O mercador disse:

— Eu sei vender. Se tivesse ao menos um pouco de dinheiro, venderia muito.

E o príncipe disse:

— Eu não sei trabalhar nem vender. Sei apenas reinar. Se tivesse um reino, reinaria bem

O camponês, então, disse:

- Eu não preciso nem de dinheiro nem de reino. Basta minhas pernas andarem e minhas mãos mexerem-se, ganharei a vida e ainda alimentarei vocês. Mas, enquanto um espera dinheiro e, o outro, um reino, ambos morrerão de fome.

E o príncipe disse:

— O mercador precisa de dinheiro, eu preciso de um reino e você precisa de força para trabalhar. Dinheiro, reino e força: tudo isso vem de Deus. Deus, querendo, 
a mim dará um reino e, a você, força. Mas, se não for a Sua vontade, Ele não lhe dará força e nem me dará um reino.

O camponês nem escutou e foi para a cidade. Na cidade, foi contratado para carregar lenha. No fim do dia, pagaram-lhe o dinheiro. Ele levou-o a seus companheiros e disse:

— Enquanto vocês ainda se preparam para reinar, eu já ganhei dinheiro.

No dia seguinte, o mercador pediu um pouco de dinheiro ao camponês e foi para a cidade.

No mercado, o mercador ficou sabendo que havia pouco óleo naquela cidade e que, todos os dias, esperavam um novo carregamento. O mercador foi até o cais e começou a observar os navios. Não tardou, e um navio com óleo ancorou. O mercador foi o primeiro a subir a bordo, encontrou o dono, comprou todo o óleo e deu algum dinheiro como garantia. Depois, correu para a cidade, revendeu o óleo e, com a sua esperteza, ganhou dez vezes mais dinheiro do que o camponês, e levou o dinheiro a seus companheiros.

O príncipe disse:

— Bem, agora é a minha vez de ir à cidade. Vocês dois tiveram sorte; talvez o mesmo aconteça comigo. Para Deus, nada é difícil: dar trabalho a você, camponês; dar lucro ao mercador; e dar um reino ao jovem príncipe.

O jovem príncipe foi para a cidade. Lá, viu gente andando aos prantos pelas ruas. O jovem príncipe foi perguntando a um e outro por que choravam. Disseramlhe:

— Será possível que você não sabe que o nosso rei morreu ontem à noite? $\mathrm{E}$ que nunca encontraremos outro rei como o nosso?

— De que ele morreu?

- Canalhas talvez o tenham envenenado.

O jovem príncipe sorriu e disse:

- Não pode ser verdade.

De repente, uma pessoa fixou os olhos no jovem príncipe, reparou que ele não falava exatamente do mesmo jeito que eles falavam, e que não se vestia como todos na cidade, e gritou:

- Pessoal! Este homem foi enviado até nós pelos assassinos para fariscar a nossa cidade. Talvez ele próprio tenha envenenado o rei. Vejam como ele fala 
esquisito e como ri enquanto todos nós choramos. Detenham-no, levem-no para a prisão.

Detiveram o jovem príncipe, levaram-no à prisão e, durante dois dias, não lhe deram comida. No terceiro dia, foram até o jovem príncipe e conduziram-no ao tribunal. Uma multidão reuniu-se para escutar o julgamento.

No tribunal, perguntaram ao jovem príncipe quem ele era e por que ele havia ido àquela cidade. $\mathrm{O}$ jovem príncipe disse:

- Sou filho do rei. Meu pai deu todo o reino ao meu irmão mais velho, minha mãe defendeu-me e, por minha causa, ambos brigavam. Eu não queria aquilo, despedi-me de meu pai e de minha mãe, e fui correr o mundo. No caminho, encontrei dois companheiros: um mercador e um camponês e, com eles, cheguei a esta cidade. No caminho, quando nos sentamos para descansar, o camponês falou que já era hora de trabalhar, cada um fazendo o que sabe; o mercador falou que sabia vender, mas que não tinha dinheiro; e eu falei que sabia apenas reinar, mas que não tinha reino. $\mathrm{O}$ camponês falou que nós morreríamos de fome, um esperando dinheiro e, o outro, um reino, que sua força estava em suas mãos, e que ele sustentaria a si e a nós. Ele veio à cidade, trabalhou, e levou-nos dinheiro. Com esse dinheiro, o mercador veio à cidade e lucrou dez vezes mais; mas eu vim à cidade e eis que sou detido e preso à toa; durante dois dias não me deram de comer e, agora, querem me executar. Mas não temo nada disso porque sei que tudo vem de Deus e, se for a Sua vontade, serei executado sem motivo por vocês, mas, se Ele quiser, serei coroado rei por vocês.

Quando ele terminou de falar, o juiz calou-se, pois não sabia o que dizer. De repente, uma pessoa gritou da multidão:

— Deus enviou-nos este príncipe. Não encontraremos um rei melhor para nós. Vamos coroá-lo rei!

E coroaram-no rei.

Depois de ser coroado, mandou buscar os seus companheiros fora da cidade, e levá-los até ele. Quando lhes contaram que o rei os chamava, eles assustaram-se: pensaram que haviam cometido alguma falta na cidade. Mas não podiam fugir e foram levados até o rei. Ambos caíram a seus pés, mas o rei ordenou que se levantassem. Então, eles reconheceram o seu companheiro. O rei contou-lhes tudo o que lhe havia acontecido e disse-lhes: 
— Viram como eu tinha razão? Tanto o mal como o bem vêm de Deus. E, para Deus, não é mais difícil dar um reino a um príncipe do que dar lucros a um mercador ou trabalho a um camponês.

Ele recompensou os seus companheiros, e permitiu-lhes que vivessem em seu reino. 
O filhote de gralha

fábula

Certa vez, um ermitão viu um falcão na floresta. $O$ falcão levou um pedaço de carne para o ninho, rasgou a carne em pequenos pedaços e começou a alimentar um filhote de gralha.

O ermitão ficou surpreso ao ver como o falcão alimentava o filhote de gralha e pensou: "Deus não abandona sequer um pequeno filhote de gralha, e Deus bem que ensinou este falcão a alimentar um órfão de outro pássaro. Vê-se que Deus provê a todos, e nós só pensamos em nós mesmos. Vou parar de me preocupar só comigo, não vou mais guardar provisões de comida. Deus provê, não abandona ninguém, e não me abandonará."

E assim ele fez: sentou-se na floresta, não saiu do lugar e só rezava a Deus. Passou três dias e três noites sem beber e sem comer. No terceiro dia, o ermitão estava tão fraco que já não podia mais erguer as mãos. De fraqueza, ele dormiu. E sonhou com um stáriets ${ }^{112}$. No sonho, o stáriets aproximou-se dele e disse:

- Por que você não faz provisões para si? Você pensa que está agradando a Deus, mas está pecando. Deus fez o mundo de maneira que cada criatura consiga aquilo de que necessita. Deus ordenou ao falcão alimentar o filhote de gralha e, sem o falcão, o filhote estaria perdido; mas você pode trabalhar. Você quer testar Deus e isso é um pecado. Acorde e trabalhe como antes.

O ermitão acordou e voltou a viver como antes.

${ }^{112} \mathrm{Na}$ Rússia antiga, santo, monge ou ermitão, considerado profeta ou taumaturgo. (N.T.) 


\section{Como aprendi a cavalgar}

relato de um senhor de terras

Quando nós morávamos na cidade, estudávamos todos os dias, salvo domingos e feriados, dias em que nós, os irmãos, passeávamos e brincávamos. Certa vez, papai disse:

— É preciso que as crianças mais velhas aprendam a cavalgar. Mande-as para o picadeiro.

Eu era o mais novo de todos os irmãos e pedi:

— E eu? Posso aprender?

Papai respondeu:

- Você vai cair.

Comecei a lhe implorar para que ele também me deixasse, e quase me pus a chorar.

Papai disse:

- Está bem, você também pode. Mas, cuidado: não chore quando cair. Aquele que não cai do cavalo não aprende a cavalgar.

Quando chegou quarta-feira, levaram-nos, a nós três, ao picadeiro. Passamos por uma grande estrada e, da estrada grande, saímos numa estradinha. Essa estradinha dava para um enorme galpão. E, naquele galpão, ao invés de tabuas, havia areia no chão. Ali cavalgavam senhores e senhoras, mas também crianças pequenas, como nós. Aquilo era um picadeiro. No picadeiro não havia muita luz, e o lugar cheirava a cavalos, ouvia-se o estalido dos chicotes, gritos dirigidos aos cavalos, e as batidas dos cascos dos cavalos nas paredes de madeira. No começo, senti medo e não pude distinguir nada. Depois, nosso preceptor chamou o picador e disse:

— Dê cavalos a esses garotos, eles vão aprender a cavalgar.

O instrutor disse:

— Está bem.

Depois, ele olhou para mim e disse:

— Este é muito pequeno.

E nosso preceptor disse:

- Ele prometeu não chorar quando cair.

$\mathrm{O}$ picador sorriu e saiu. 
Depois, trouxeram-nos três cavalos selados; tiramos nossos capotes e descemos a escada, até o picadeiro; o picador segurava os cavalos por uma corda ${ }^{113}$, e meus irmãos rodavam em volta dele.

No começo, eles iam a passo, depois, a trote. Em seguida, trouxeram um pequeno cavalinho. Ele era vermelho e o seu rabo havia sido cortado. Seu nome era Tchervóntchik ${ }^{114}$. O instrutor sorriu e disse-me:

- Vamos, cavaleiro, monte.

Fiquei contente e com medo, mas esforcei-me para que ninguém notasse. Durante bastante tempo, esforcei-me para alcançar o estribo com um dos pés, mas não havia jeito, porque eu era muito pequeno. Então, o picador pegou-me nos braços e sentou-me na sela. Ele disse:

- O senhor não é pesado, duas libras apenas, não mais do que isso.

No começo, ele segurava-me pelo braço; mas vi que não seguravam meus irmãos, e pedi-lhe que me largasse. Ele perguntou-me:

— Mas o senhor não tem medo?

$\mathrm{Eu}$ estava com muito medo, mas disse que não. Eu sentia mais medo ainda porque Tchervóntchik encolheu bem as orelhas. Pensei que ele estava zangado comigo. O instrutor disse:

— Tome cuidado, não vá cair! — e soltou-me. No começo, Tchervóntchik andava a passo, e eu mantinha-me reto. Mas a sela estava escorregadia e fiquei com medo de cair. O picador perguntou-me:

— E então? Está firme?

E eu respondi-lhe:

— Estou firme.

— Então, agora galope. - e o picador estalou a língua.

Tchervóntchik pôs-se a correr num leve galope e começou a me jogar para o alto. Mas fiquei calado e esforcei-me para não cair para o lado. O picador elogiou-me:

— Mas que cavaleiro! Muito bem!

Nesse momento, um amigo do picador aproximou-se dele, ambos começaram a conversar, e o picador deixou de olhar para mim.

Mas, de repente, percebi que eu havia escorregado um tanto para um lado da sela. Tentei voltar, mas não consegui. Ia gritar para chamar o picador para que ele

\footnotetext{
${ }^{113}$ Corda usada para fazer o cavalo andar em círculos. (N.A.)

${ }^{114}$ Em russo arcaico, vermelho. (N.T.)
} 
parasse o cavalo, mas pensei que ficaria com vergonha se fizesse isso, e calei-me. $\mathrm{O}$ picador não estava me olhando. Tchervóntchik continuava galopando, e eu escorreguei ainda mais para o lado. Olhei para o picador e pensei que ele fosse me socorrer; mas ele continuava conversando com o seu amigo e, sem olhar par mim, repetia:

— Isso mesmo, cavaleiro!

Eu já estava totalmente na beira da sela, e fiquei muito assustado. Pensei que eu estava perdido. Mas, seria uma vergonha gritar. Tchervóntchik deu mais um solavanco, acabei escorregando de vez, e caí no chão. Então, Tchervóntchik parou, o picador olhou e viu que eu não estava mais sobre o cavalo. Ele disse:

— Puxa! Meu cavaleiro caiu! - e aproximou-se de mim. Quando eu lhe falei que não havia me machucado, ele sorriu e disse:

- Crianças têm o corpo macio.

Senti vontade de chorar. Pedi-lhe para me colocar outra vez sobre a sela, e ele colocou-me. E eu não caí mais.

Assim, nós íamos ao picadeiro duas vezes por semana. Logo aprendemos a cavalgar bem, e eu não senti mais medo. 
O machado e a serra

fábula

Dois camponeses foram à floresta para rachar lenha. Um tinha um machado e, o outro, uma serra. Então, eles escolheram uma árvore e começaram a discutir. Um dizia:

— Temos de machadar a árvore.

E o outro dizia:

— Temos de serrá-la.

Então, um terceiro camponês disse:

- Vou reconciliar vocês agora: se o machado estiver afiado, melhor será machadar, mas se a serra estiver mais afiada do que ele, então, o melhor será serrar.

Ele pegou o machado e começou a machadar a árvore. Mas o machado estava tão cego que era impossível cortá-la.

Ele pegou a serra: era uma serra ruim, e não serrava nada. Então, ele disse:

- Esperem para discutir; o machado não corta e a serra não serra. Primeiro, amolem o machado e afiem a serra e, depois, discutam.

Então, aqueles camponeses ficaram ainda mais bravos um com o outro porque um tinha um machado sem fio e, o outro, uma serra cega, e começaram a bater, um no outro. 


\section{Vida de um soldado}

relato de um mujique

Nós vivíamos pobremente, no fim da aldeia. Eu tinha mãe, uma babá (minha irmã mais velha) e uma avó. Vovó usava um corpete velho e uma vasquinha ${ }^{115}$ surrada, cobria a cabeça com um trapo e, no pescoço, usava uma bolsinha pendurada ${ }^{116}$. Vovó amava-me e sentia mais pena de mim do que minha mãe. Meu pai estava no Exército. Diziam que ele bebia muito e, por isso, mandaram-no para o Exército $^{117}$. Como num sonho, lembro-me dele chegando em casa quando estava de licença. Nossa isbá era apertada e sustentada, no centro, por uma forquilha, e, lembrome de como eu subia naquela forquilha e de como caí e machuquei a testa. Desde então, carrego uma cicatriz na testa.

$\mathrm{Na}$ isbá havia duas pequenas janelas e, uma delas, estava sempre vedada com trapos. Nosso quintal era estreito e não tinha cerca. No meio dele havia uma velha selha ${ }^{118}$. No quintal, havia apenas um pangaré velho e torto; vaca, nós não tínhamos, tínhamos duas miseráveis ovelhinhas e um cordeiro. Eu sempre dormia com ele ${ }^{119}$. Nós comíamos um mingau de pão e água. Não havia ninguém para trabalhar: minha mãe vivia com dor de barriga e, vovó, sempre sentada ao lado da piétchka, com dor de cabeça. Só a minha babá trabalhava, mas para si, e não para a família: ela comprava roupas e preparava-se para se casar.

Lembro-me de que a minha mãe ficou mais doente ainda e que, depois, deu à luz um menino. Levaram mamãe para a varanda ${ }^{120}$. Vovó pediu emprestado cereais

\footnotetext{
${ }^{115}$ Saia com muitas pregas na cintura, usada por camponesas. (N.T.)

${ }^{116}$ Era comum entre as camponesas o uso de pequenas bolsas de tecido, ou tecidas, tanto penduradas no pescoço como na cintura. Nelas, guardavam-se sementes, utensílios como faca, colher, etc., e alguma comida que levavam consigo quando saíam para trabalhar nos campos. (N.T.)

${ }^{117}$ A disciplina do Exército é considerada um meio de correção. Antes de 1874, quando, na Rússia, instituiu-se o serviço militar obrigatório, era a comunidade que decidia quem devia ser enviado para o Exército. (N.T.)

${ }^{118}$ Selha de madeira que podia ser usada tanto para deixar a roupa de molho como para o banho da família.

${ }^{119}$ No inverno, famílias muito pobres levavam seus poucos animais para dentro da isbá.

${ }^{120}$ Aqui, é necessário entender o termo "varanda" como um cômodo de frente nas casas rústicas (Dic. Aurélio, acepção 9). A religião ortodoxa considerava que a mulher que acabava de dar à luz uma criança permanecia impura durante 40 dias. Сени ou, conf. nossa tradução, «varanda», é um cômodo de fácil acesso, à entrada da isbá, o que evitaria, portanto, a profanação do seu interior. Embora sempre fechada, a varanda é o único cômodo não aquecido, e, obviamente, a história aqui contada não ocorreu no inverno, o que permitia que a mãe fosse instalada fora da isbá propriamente dita. Ademais, também por costume, os pais não assistiam às cerimônias de batismo e de casamento dos filhos. (N.T.)
} 
ao vizinho e mandou tio Nefiod chamar o pope. E minha babá foi chamar gente para o batismo.

As pessoas chegaram e trouxeram três grandes pães redondos. Os parentes começaram a montar mesas e, depois, estenderam toalhas.

Depois, trouxeram bancos e uma bacia com água. E todos sentaram-se em seus lugares. Quando o pope chegou, o padrinho e a madrinha ficaram na frente, e tia Akulina ficou atrás, com o bebê. Começaram a rezar. Depois, despiram o bebê, o pope pegou-o e mergulhou-o na água. Fiquei assustado e gritei:

- Devolva o bebê!

Mas vovó ficou zangada comigo e disse:

- Cale-se, ou bato em você.

O pope mergulhou-o três vezes e entregou-o à tia Akulina.Titia enrolou-o num pano de algodão e levou-o até a varanda, para minha mãe.

Depois, todos se sentaram à mesa; vovó encheu duas tigelas com kacha ${ }^{121}$, regou com óleo e serviu às pessoas. Quando todos terminaram de comer, deixaram as mesas, agradeceram à minha avó e foram embora.

Fui até minha mãe e perguntei:

— Má, qual é o nome dele?

Minha mãe respondeu:

- O mesmo que o seu ${ }^{122}$.

O menino era magrinho; suas perninhas e bracinhos eram franzinos e ele não parava de gritar. A qualquer hora da noite, ele não parava de gritar, e mamãe ninava-o com cantigas. Ela própria gemia, mas cantava mesmo assim.

Certa vez, levantei-me à noite e escutei mamãe chorando. Vovó levantou-se e perguntou:

— Cristo! O que aconteceu com você?

Mamãe respondeu:

- A criança morreu.

Vovó acendeu a lamparina, lavou o bebê, vestiu-o com uma pequena camisa limpa, amarrou-o com uma faixa de pano $^{123}$ e colocou-o embaixo dos ícones ${ }^{124}$.

\footnotetext{
${ }^{121}$ Mingau muito popular na Rússia. Dependendo da região do país, ele pode ser preparado com vários tipos de grãos, com tubérculos ou com legumes. Na Rússia Central, região de Tolstói, o grão mais usado para o preparo da kacha é o trigo sarraceno. (N.T.)

${ }_{122}$ Era comum, na Rússia, que as crianças recebessem o mesmo nome do santo cujo dia era comemorado no dia em que nasciam. O nome era, em geral, escolhido pelo pope. Há, na religião ortodoxa, santos homônimos, cuja festa celebra-se em diferentes dias do ano. (N.T.)
} 
Quando amanheceu, vovó saiu da isbá e voltou com titio Nefiod. Titio trouxe duas tábuas velhas e começou a fazer um caixãozinho. Quando ele ficou pronto, titio colocou o bebê naquele pequeno caixão. Depois, minha mãe sentou-se ao lado dele e, com uma voz aguda, começou a se lamentar ${ }^{125}$. Depois, titio Nefiod pegou o caixãozinho, colocou-o debaixo do braço e levou-o para enterrá-lo.

Nós só tivemos alegria quando minha babá se casou. Certa vez, alguns mujiques foram até a nossa isbá, levaram consigo aguardente e pão. E começaram a oferecer aguardente para mamãe. Ela bebeu. Tio Ivã cortou uma fatia de pão e deu a ela. Fiquei de pé, atrás da mesa, e senti vontade de comer um pedacinho do pão. Inclinei-me até mamãe e cochichei-lhe no ouvido. Ela riu, e tio Ivã perguntou:

— O que ele quer? Um pedacinho do pão? - e cortou-me uma fatia grossa.

Peguei o pão e fui para a despensa. Minha babá estava sentada lá. Ela começou a me perguntar:

— O que os mujiques estão falando lá dentro?

E eu respondi:

— Estão bebendo aguardente.

Ela sorriu e disse:

—É que eles estão me pedindo em casamento para Kondrachka.

Depois, começaram a preparar o casamento. Todos acordaram cedo. Vovó acendeu a piétchka, mamãe sovava a massa dos pães e tia Akulina lavava a carne.

Minha irmã calçou coturnos novos, vestiu um $\operatorname{sarafan}^{126}$ vermelho, colocou um xale novo e não ajudava em nada. Depois, quando a isbá ficou aquecida, minha mãe também trocou de roupa, muita gente chegou, e a isbá ficou cheia.

Depois, entraram no nosso quintal três pares de cavalos com sinos. E, no último par, estava Kondrachka sentado, com um novo cafetã e com uma chapka ${ }^{127}$ alta. O noivo desceu da telega e entrou na isbá. Vestiram um casaco novo de pele na minha babá e levaram-na até o noivo. Puseram o noivo e a noiva à mesa e as mulheres

\footnotetext{
${ }^{123}$ Da vestimenta dos mortos fazia parte um cinto, ou faixa, ambos confeccionados com tecido, e, sobre ele, uma prece inscrita. (N.T.)

${ }^{124}$ Toda casa russa possui o "canto santo", ou seja, um canto entre duas paredes, de frente para a porta de entrada onde, em geral, sobre uma prateleira, ficam os ícones. Sob eles, há uma pequena mesa com velas e o Livro de Orações. A criança morta foi colocada sobre uma mesa como esta. (N.T.)

${ }^{125}$ É comum, não apenas na Rússia, mas também em vários países do Leste europeu, prantos e lamúrias em homenagem aos mortos. Tal costume lembra-nos os choros e queixumes das antigas carpideiras. (N.T.)

${ }_{126}$ Típico traje russo, bastante colorido (em geral, vermelho), usado por camponesas, sobretudo, jovens. (N.T.)

${ }^{127}$ Típico chapéu russo, feito com peles de animais. (N.T.)
} 
começaram a cantar. Depois, deixaram a mesa, rezaram a Deus e todos foram para o quintal. Kondrachka acomodou minha babá numa telega e sentou-se em outra. Todos se sentaram nas telegas, benzeram-se e partiram. Eu voltei para a isbá e sentei-me à janela para esperar o retorno do comboio. Minha mãe deu-me uma fatia de pão; comia e logo adormeci. Depois, mamãe acordou-me e disse:

— Eles estão chegando!

Ela deu-me um rolo de massa, e mandou-me sentar à mesa. Kondrachka e minha babá entraram na isbá e, atrás deles, vinha muita gente, bem mais do que antes. A rua estava cheia de gente, e todos nos olhavam pelas janelas. Titio Guerasin era o padrinho do noivo. Ele aproximou-se de mim e disse:

- Saia daí.

Eu fiquei com medo e ia obedecer quando vovó disse:

- Mostre o rolo a Kondrachka e pergunte:

— Você sabe o que é isto? ${ }^{128}$

Eu obedeci. Titio Guerasin colocou dinheiro num copo, verteu vinho em cima dele e deu-o a mim ${ }^{129}$. Peguei o copo e entreguei-o a vovó. Então, nós saímos, e eles sentaram-se.

Depois, começaram a servir vinho, geleia de mocotó e carne de boi; começaram a cantar e a dançar. Serviram aguardente ao tio Guerasin, ele bebeu um gole e disse:

— Esta água está amarga ${ }^{130}$.

Então, minha babá pegou Kondrachka pela orelha e começou a beijá-lo. Cantaram e dançaram durante bastante tempo; depois, todos se foram e Kondrachka levou minha babá consigo para a sua casa.

Depois disso, nossa vida ficou ainda mais pobre. Venderam o cavalo e as últimas ovelhas, e nem sempre tínhamos pão. Mamãe pedia emprestado aos parentes. Logo vovó morreu. Lembro-me de como minha mãezinha gritava e lamentava-se: ${ }^{131}$

\footnotetext{
128 Trata-se de resquícios do "casamento por rapto", bastante comum na Europa do Leste. Nessa tradição, o noivo finge raptar a noiva, e, no texto em questão, na ausência do pai, o menino era o chefe da casa, portanto, quem devia defender a irmã, ameaçando, com um rolo de massa nas mãos, o noivoraptor. (N.T.)

${ }^{129}$ Trata-se de um resquício de casamentos pré-negociados. Pode igualmente ser entendido como um costume equivalente àquele de se cortar a gravata do noivo e distribuir, entre os convidados, pequenos pedaços do tecido em troca de dinheiro que, para os noivos recém-casados, talvez seja uma ajuda importante. (N.T.)

${ }^{130}$ Em festas de casamentos nas aldeias, é usual que os convidados gritem: “Amargo!”, ou frases como "Esta aguardente parece amarga, é preciso adoçá-la!” para que os noivos se beijem. (N.T.)
} 
- Ah, minha mãezinha querida! Nas mãos de que quem eu, pobre e miserável, fiquei? Nas mãos de quem você deixou a sua infeliz filhinha? Quem, agora, irá me guiar? Como vou viver a minha vida?

E, assim, ela chorava e lamuriava-se muito.

Certa vez, eu fui com outros meninos por uma grande estrada para vigiar cavalos, e vi um soldado caminhando com uma sacola pendurada nos ombros. Ele aproximou-se de nós e perguntou:

— De que aldeia são vocês, meninos?

Nós respondemos:

— De Nikolskóie.

— Ah, então lá vive Matriona, mulher de um soldado?

$\mathrm{Eu}$, então, disse:

— Sim, vive, ela é minha mãe.

O soldado olhou para mim e disse:

— E o seu pai, você o tem visto?

E eu disse:

— Não, não o tenho visto, ele está no Exército.

O soldado, então, disse:

- Bom, vamos, leve-me até Matriona, eu trouxe-lhe uma carta de seu pai.

Eu perguntei:

- Que carta?

E ele respondeu:

— Vamos e você verá.

— Já que é assim, vamos, então.

O soldado e eu fomos andando, mas ele ia tão rápido que, mesmo correndo atrás dele, eu não o alcançava. Finalmente chegamos a casa. O soldado fez uma prece e disse:

— Saudações!

- Depois, tirou o casaco, sentou-se no parapeito da janela, começou a olhar toda a isbá e disse:

- Como? Sua família é assim pequena? Minha mãe ficou com vergonha e não disse nada, só olhou para o soldado. Então, ele perguntou:

${ }^{131}$ Ver nota 12. (N.T.) 
— Onde está mamãe?

E começou a chorar. Então, minha mãe correu até meu pai e começou a beijálo. Eu também pulei voando nas suas pernas e comecei a abraçá-lo. Ele parou de chorar e desatou a rir.

Depois, chegaram os vizinhos, meu pai cumprimentou todos e contou-lhes que, então, já o tinham totalmente dispensado.

Quando trouxeram o gado, minha babá chegou e beijou meu pai. Papai perguntou:

— Quem é essa moça?

— Minha mãe riu e perguntou:

— Não reconhece a sua própria filha?

- Papai chamou-a para perto de si, beijou-a e perguntou-lhe como ela estava. Depois, mamãe foi fritar ovos, e mandou minha irmã pegar aguardente. Minha irmã pegou uma botija fechada com papel e colocou-a sobre a mesa. Papai perguntou:

— O que é isso?

— Aguardente para você.

Ele, então disse:

— Não, há cinco anos eu não bebo; só quero ovos. Ele fez uma prece, sentouse à mesa e começou a comer. Depois, ele disse:

- Se eu não tivesse parado de beber, não teria sido sargento e não teria trazido nada para casa, mas, agora... graças a Deus.

E ele tirou da sacola um embrulho com dinheiro e deu-o a minha mãe. Mamãe ficou feliz, pegou logo o dinheiro e guardou-o.

Depois, quando todos foram embora, papai deitou-se para dormir no banco do fundo, e acomodou-me junto com ele, e mamãe deitou-se conosco, no pé da cama. E eles conversaram muito tempo, quase até a meia-noite. Depois, eu dormi.

Na manhã seguinte, mamãe disse:

- Ah, acabou a lenha!

E papai perguntou:

— Você tem um machado?

— Tenho sim, mas um machado ruim.

Papai calçou-se, pegou o machado e foi para o quintal. Corri atrás dele.

Papai puxou uma vara comprida do teto, colocou-a num cepo, ergueu o machado, rachou-a depressa, levou-a para a isbá e disse: 
— Pronto, aqui está a sua lenha, acenda a piétchka; e hoje eu vou procurar uma isbá para comprar, e madeira para armazenar. Tenho de comprar uma vaca também.

Mamãe disse:

— Ah, é preciso muito dinheiro para tudo isso.

E papai disse:

— Podemos trabalhar. Veja, o mujique já está crescendo. - E papai apontou para mim.

Papai fez uma prece, comeu um pedaço de pão, agasalhou-se e disse a mamãe:

- Se tiver ovos frescos, então asse-os para o almoço no meio das cinzas. E foi embora.

Ele demorou a voltar. Eu comecei a pedir a mamãe para me deixar ir procurálo. Ela não deixou. Mesmo assim, tentei ir, mas mamãe não deixou e deu-me um tapa. Sentei-me na piétchka e comecei a chorar. Então, papai entrou na isbá e perguntou:

— Por que você está chorando?

Eu respondi:

- Eu queria correr atrás de você, mas mamãe não deixou, e ainda me bateu.

E chorei mais ainda. Papai riu, foi até mamãe, e começou a bater nela de brincadeira, dizendo:

- Não bata no Fedka, não bata no Fedka!

Mamãe fingiu chorar, papai riu e disse:

- Mas você e o Fedka, vocês dois são manteiga derretida, choram por qualquer coisa. Depois, papai sentou-se à mesa, acomodou-me ao seu lado e gritou:

- E agora, mãe, traga logo o almoço: eu e Fedka estamos com fome.

Mamãe deu-nos kacha e ovos, e nós começamos a comer. Então, ela perguntou:

— E então? comprou madeira para a isbá?

E papai respondeu:

- Comprei: oitenta rublos de tília, branca como vidro. É preciso esperar, vamos comprar aguardente para os mujiques, e eles trarão a madeira num domingo.

Desde então, nós passamos a viver bem. 


\section{O gato e os ratos \\ fábula}

Muitos ratos aparecem numa casa. Um gato entrou nessa casa e começou a caçá-los. Os ratos viram que a coisa ia mal e disseram:

- Muito bem, ratos, não vamos mais sair deste teto, pois o gato não conseguirá nos pegar aqui!

Como os ratos pararam de descer, o gato pensou num jeito de ser mais astuto do que eles. Com uma das patas, agarrou-se ao teto, ficou pendurado e fingiu-se de morto. Um rato deu uma olhada nele e, então, disse:

— Não, irmão! Você pode até se transformar numa saca: nem assim chegarei perto. 


\section{O gelo, a água e o vapor \\ raciocínio}

O gelo pode ser duro como uma pedra. Se um pedaço de pau ficar preso dentro do gelo, esse pau não poderá ser retirado enquanto o gelo não derreter. Quando o gelo está duro, carroças podem andar sobre ele sem afundar e, se jogarmos sobre ele dez puds ${ }^{132}$ de ferro, ele não afundará.

Quanto mais frio, mais duro o gelo fica. Quando o gelo esquenta, ele enfraquece, tornando-se uma espécie de mingau; podemos retirar com a mão algo que tenha ficado dentro dele; ele afunda sob nossos pés e não suporta sequer uma libra ${ }^{133}$ de ferro. Quanto mais intenso o calor, mais o gelo se transforma em água. Qualquer objeto pode ser facilmente retirado dela e a água não suporta mais peso algum, exceto o da madeira. Se aquecermos ainda mais a água, ela suportará menos peso ainda. É mais fácil nadar em água fria do que em água morna. E, em água quente, a madeira afunda.

Se aquecermos ainda mais a água, ela dispersar-se-á em forma de vapor; e o vapor não suporta mais peso nenhum; ele próprio se dissipa em todas as direções.

Se fervermos a água numa panela tampada, essa água evaporará e instalar-se-á sob a tampa, gotejará, escorregará e, novamente, transformar-se-á em água. Se pegarmos essa água, e se a colocarmos no frio, ela transformar-se-á novamente em gelo.

Aqueça a água e obterá vapor; esfrie a água e obterá gelo. Aquecida, essa mesma água dispersar-se-á e, congelada, solidificar-se-á.

Não há nenhum calor no gelo, há pouco calor na água, mas há muito calor no vapor.

Se encostarmos um pedaço de gelo num bloco de gelo, esse bloco não esquentará nem resfriará.

Mas, se despejarmos água sobre o gelo, o gelo, então, esquentará, e a água esfriará. O gelo derreterá se houver muita água, e a água congelará se houver muito gelo.

\footnotetext{
${ }^{132}$ Medida antiga de peso, equivalente a $16,38 \mathrm{~kg}$. (N.T.)

${ }^{133}$ Medida de peso, equivalente a 0,409 g. (N.T.)
} 
E se liberarmos vapor sobre o gelo, o gelo esquentará e o vapor esfriará: o gelo derreterá, transformando-se em água, e o vapor esfriará, transformando-se também em água.

Se a água estiver fria e o ar estiver frio, a água não esquentará, e tampouco o ar esfriará. Mas, se o ar estiver quente e a água estiver fria, o que acontecerá? O calor do ar passará para a água, a água ficará cada vez mais quente e, o ar, cada vez mais frio, até se igualarem.

Se o ar estiver mais quente do que a água, a água esquentará e o ar esfriará; mas, se a água estiver mais quente do que o ar, o ar ficará mais quente, e a água ficará mais fria.

Se, no ar, a água líquida congela-se, significa que a água está mais quente do que o ar: ela esfriará, e o ar esquentará.

Se a água voadora torna-se água líquida, significa que o ar está mais frio do que a água voadora: a água esfriará, e o ar esquentará.

Se, no ar, a água dura transforma-se em líquida, significa que o ar está mais quente: ele esfriará, endurecerá, e o gelo esquentará.

Se, no ar, a água transforma-se em vapor, ela seca-se; significa que o ar está mais quente: ele esfriará, e a água esquentará.

O gelo não pode aquecer, mas a água e o vapor podem aquecer. Eis como é possível aquecer com água: levar água para uma casa fria. Quando a água congelar, jogar o gelo fora. Ela congelará novamente e, novamente, jogá-la fora. Na casa, ficará bem mais quente e, assim, a água não mais se congelará.

Por que isso acontece? Porque quando a água congela, ela libera o calor excedente no ar e, assim, continua liberando calor até que o ar aqueça e a água pare de congelar.

Eis como aquecer com vapor: libera-se vapor numa casa fria. $\mathrm{O}$ vapor resfria, começa a gotejar e transforma-se em água. Esta água é levada para fora, e a casa esquenta.

Por que isso acontece? Porque, assim que o vapor transforma-se em água, ele libera o calor excedente no ar.

Quando a água transforma-se em gelo, e o vapor transforma-se em água, o calor da água e do vapor penetra no ar e, assim, o ar torna-se mais quente. E quando o gelo transforma-se em água, e a água transforma-se em vapor, o calor do ar transferese para a água e para o vapor, e o ar torna-se mais frio. 
Se quisermos esfriar um cômodo quente, basta colocarmos gelo nele, e deixar o gelo derreter. Por que ficará mais frio? Porque, para se transformar em água, o gelo absorve o calor do ar.

Se quisermos refrescar, basta jogarmos água e deixá-la secar. Por que isso acontece? Porque a água se transforma em vapor. E porque a água se transforma em vapor, ela absorve muito calor do ar.

Por isso é mais frio quando chove, e mais quente antes de chover. Quando chove, a água seca, evapora e absorve o calor. Antes de chover, vapores circulam no ar e esfriam as nuvens: é delas que vem o calor.

Por isso dizem que está abafado. 
A codorna e seus filhotes

fábula

Alguns camponeses ceifavam um campo e, no campo, embaixo de um montículo, havia um ninho de codorna.

A codorna voltou voando, levando comida para o ninho, e viu que, ao redor, tudo havia sido ceifado. Então, ela disse a seus filhotes:

— Meus filhos, a desgraça chegou! Fiquem calados agora e não se mexam, ou estarão perdidos. À noite, levarei vocês daqui.

Mas os filhotes estavam felizes porque o campo havia ficado mais claro, e disseram:

— Mamãe é velha, e é por isso que ela não quer que nós nos divirtamos - e começaram a piar e a assobiar.

Crianças levaram almoço aos camponeses que ceifavam, ouviram os filhotes e torceram-lhes os pescoços. 
Bulka

relato de um oficial

Eu tinha um mastiff ${ }^{134}$. Seu nome era Bulka. Ele era todo preto, apenas as pontinhas de suas patas dianteiras eram brancas.

O maxilar inferior desses cães é mais longo do que o superior, e os dentes de cima ultrapassam os de baixo, mas o maxilar inferior de Bulka era tão proeminente que se podia enfiar o dedo entre os dentes inferiores e superiores. Bulka tinha um focinho largo; olhos grandes, pretos e brilhantes; e seus brancos e salientes dentes caninos estavam sempre para fora. Ele se parecia com um mouro. Bulka era manso e não mordia, mas era muito forte e tinha uma dentada firme. Quando acontecia de ele abocanhar alguma coisa, apertava os dentes com força e ficava pendurado como um trapo e, tal um carrapato, era impossível arrancá-lo.

Certa vez, soltaram-no atrás de um urso, ele agarrou-se à orelha do animal e ficou pendurado como uma sanguessuga. O urso dava-lhe patadas, apertava-o contra si, balançava a cabeça de um lado para o outro, mas não conseguia se livrar; então, ele jogou-se de cabeça no chão para esmagar Bulka. Mas Bulka permaneceu agarrado a ele até que lhe despejaram água fria.

Eu peguei-o ainda filhote e criei-o. Quando fui servir no Cáucaso, não queria levá-lo comigo, saí sem que ele percebesse e mandei que o trancassem. Na primeira estação, eu já estava pronto para me sentar em outro carro de posta quando, de repente, vi uma coisa preta e brilhante rolando pela estrada. Era Bulka com a sua coleira de cobre. Ele corria a todo vapor para a estação. Pulou em mim, lambeu minha mão e esticou-se à sombra, embaixo da telega. Espichou um palmo a língua. Ora guardava-a para engolir a saliva, ora estirava-a a um palmo de distância. Ele estava agitado, sem fôlego, e seus flancos tremelicavam. Virava-se ora de um lado, ora de outro, e batia o rabo na terra.

Mais tarde, eu sobre que, depois que parti, ele havia quebrado o vidro e pulado pela janela, seguiu o meu rastro, pulando pela estrada, e galopando cerca de vinte verstas $^{135}$ em pleno calor.

\footnotetext{
${ }^{134}$ Cão de guarda, muito grande e forte. (N.T.)

${ }^{135}$ Antiga unidade russa de medida, equivalente a 1.066,8 metros. (N.T.)
} 


\section{Bulka e o javali}

conto

Certa vez, no Cáucaso, nós saímos para caçar javalis, e Bulka foi comigo. Os galgos puseram-se a caçar, Bulka acudiu a seus chamados e embrenhou-se na floresta. Era o mês de novembro, época em que os javalis e os porcos estão bastante gordos.

No Cáucaso, nas florestas onde vivem os javalis, há muitos frutos deliciosos. Depois de esses frutos amadurecerem e enfrentarem a geada, os javalis fartam-se deles e engordam.

Nessa época, o javali fica tão gordo que mal consegue correr dos cães. Se for perseguido durante duas horas, ele esconde-se na mata e nela fica. Então, os caçadores correm até o lugar onde ele está e atiram. Pelos latidos dos cães é possível saber se o javali está parado ou se está correndo. Se está correndo, os cães latem e ganem como se os estivessem apanhando, mas, se ele para, os cães latem como se estivessem latindo para uma pessoa, e uivam.

Durante aquela caçada, corri muito pela floresta, mas não encontrei mais nenhum javali no caminho. Finalmente, escutei um longo latido e os bramidos dos cães galgos, e corri na direção deles. Eu já estava perto do javali. E logo comecei a escutar um estalido na mata. Eram os cães às voltas com o javali. Pelos latidos, eles não o haviam agarrado, mas o estavam cercando. De repente, ouvi um frufru qualquer atrás, e vi Bulka. Era provável que ele houvesse perdido os galgos na floresta e estivesse confuso, mas, naquele momento, assim como eu, ele também ouvira os latidos e correra na direção deles. Bulka atravessou correndo uma clareira, mas o capim alto permitia-me ver apenas sua cabeça preta e a língua presa entre os dentes brancos. Chamei-o, mas ele não ligou, passou por mim e desapareceu na mata. Corri atrás dele, mas quanto mais eu andava, a floresta tornava-se mais e mais fechada. Os galhos arrancavam minha chapka, batiam-me no rosto, os espinhos dos abrunheiros prendiam-se no meu casaco. Eu já estava perto dos latidos, mas não conseguia ver nada.

De repente, ouvi os cães latirem mais alto, um forte estalido, e o javali, que começava a resfolegar com voz rouca. Tal como eu pensara: Bulka o havia alcançado e lutava com ele. Reuni minhas últimas forças e corri pela mata, naquela direção. $\mathrm{Na}$ 
mais espessa mata, vi um cão galgo todo malhado. Ele latia e uivava e, a três passos dele, algo preto remexia-se.

Quando me aproximei mais, vi o javali e escutei Bulka esganiçando estridentemente. O javali começou a grunhir e avançou no galgo; o galgo encolheu o rabo e pulou. Pude ver o flanco e a cabeça do javali. Mirei o flanco e atirei. Vi que havia acertado. $\mathrm{O}$ javali soltou um grunhido e fugiu de mim, pisando em galhos secos. Ganindo e latindo, os cães seguiram-no, e eu embrenhava-me no matagal atrás deles. De repente, quase embaixo dos meus pés, vi e ouvi alguma coisa. Era Bulka. Ele estava caído de lado e gania. Embaixo dele havia uma poça de sangue. Pensei: "é o seu fim", mas, naquele momento, isso não importava, e segui adiante. Logo depois, avistei o javali. Os cães estavam agarrando-o por trás, e ele virava-se ora para um lado, ora para outro lado. Quando me viu, o javali precipitou-se em minha direção. Atirei uma segunda vez, quase à queima-roupa, de modo que suas cerdas quase chamuscaram; o javali grunhiu, começou a cambalear e, com o seu corpanzil, caiu pesadamente no chão.

Quando me aproximei, o javali já estava morto. Eriçado, um dos cães rasgavalhe a barriga e as pernas e, os outros, lambiam o sangue da ferida.

Então, lembrei-me de Bulka e fui buscá-lo. Ele rastejava na minha direção e gemia. Aproximei-me dele e sentei-me para ver a sua ferida. Sua barriga estava rasgada e, caído como uma bola, todo o intestino arrastava-se atrás dele, sobre as folhas secas. Quando meus companheiros chegaram, enfiamos os intestinos em Bulka e costuramos a sua barriga. Enquanto costuravam a sua barriga e perfuravam a sua pele, ele lambia as minhas mãos.

Amarraram o javali ao rabo de um cavalo para retirá-lo da floresta. Puseram Bulka sobre o cavalo e, assim, levaram-no para casa. Depois de passar seis semanas doente, Bulka sarou. 
Os faisões

descrição

No Cáucaso, galinhas selvagens são chamadas de faisões. Há tantas que, lá, elas são mais baratas do que as galinhas domésticas. Os faisões são caçados com telas.

Eis como se caça com um caixilho: pega-se uma lona, prende-se essa lona numa moldura, no centro da moldura coloca-se uma barra e faz-se um buraco na lona. Chamam a essa moldura e lona caixilho. Com esse caixilho e com uma espingarda, entra-se, de madrugada, na floresta. Os caçadores levam o caixilho à frente do corpo e olham pela fenda, à procura de faisões. $\mathrm{Na}$ aurora, os faisões alimentam-se nas clareiras: algumas vezes, toda a ninhada - a galinha e os pintinhos - ; outras vezes, o galo e as galinhas; e, outras vezes ainda, alguns galos juntos.

Os faisões não veem as pessoas, não sentem medo da tela e deixam-nas aproximarem-se deles. Então, o caçador coloca a tela no chão, passa o cano da espingarda pela fenda e atira no alvo.

Eis como se caça com um vira-lata: solta-se um vira-lata na floresta e vai-se atrás dele. Quando o cão encontrar um faisão, vai-se atirando atrás da ave. O faisão voa para uma árvore e, então, o cãozinho começa a latir para ele. O caçador segue os latidos e dispara contra o faisão, sobre a árvore. Esse tipo de caça seria fácil se o faisão ficasse sentado na árvore, num galho pelado e de frente, de modo que pudesse ser visto. Mas os faisões sempre ficam em árvores densas, em plena mata, e quando avistam os caçadores, escondem-se entre os galhos. Assim, fica difícil penetrar na mata e chegar até a árvore em que o faisão está, e é difícil também vê-lo. Quando um cão late para um faisão, a ave não sente medo dele, fica no galho e bate as asas, parecendo um galo de rinha. Mas, assim que vê um homem, ela se deita no galho de modo que apenas um caçador experiente consegue vê-la; uma pessoa inexperiente ficaria ao lado dela e não veria nada.

Ao se aproximarem dos faisões, os cossacos cobrem o rosto com a chapka e não olham para cima porque o faisão tem medo de homem armado de espingarda $\mathrm{e}$ tem ainda mais medo dos olhos do homem.

Eis como se caça com um perdigueiro: leva-se um cão-perdigueiro à floresta $\mathrm{e}$ vai-se atrás dele. O faro dos cães mostra-lhes por onde os faisões andaram e onde 
comeram na aurora, e eles começam a seguir os seus rastros. E, por mais que os faisões andem para cá e para lá, um bom cão sempre encontrará o seu último rastro, que indicará por onde saíram depois de se alimentarem. Quanto mais o cão avança atrás do rastro, mais forte fica o seu faro e, assim, ele chega até o lugar onde, durante o dia, o faisão esteve sobre a relva, ou por onde ele andou. Quando o cão se aproxima, ele tem a sensação de que o faisão já está lá, à sua frente, e ele segue, com mais cuidado ainda, a fim de não o assustar, e para com a finalidade de, em seguida, pular e pegá-lo. Quando o cão chega bem perto, o faisão voa e o caçador dispara. 


\section{Milton e Bulka}

Comprei um cão perdigueiro para caçar faisões. Este cão chamava-se Milton: ele era alto, bravo, cinza-malhado, tinha bochechas e orelhas longas, e era muito forte e inteligente. Ele e Bulka não brigavam. Nunca nenhum cão rosnou para Bulka. Era só ele mostrar seus dentes, os outros cães punham o rabo entre as pernas e davam o fora. Certa vez, saí com Milton para caçar faisões. De repente, Bulka chegou correndo pela floresta, até me alcançar. Tentei mandá-lo voltar, mas não houve jeito. E levá-lo para casa seria um longo caminho. Achei que ele não me atrapalharia e segui adiante, mas, mal Milton farejou um faisão na relva e começou a procurá-lo, Bulka correu para frente e começou a se enfiar em todos os lados. Ele esforçava-se para pegar o faisão antes de Milton. Era só escutar um barulhinho qualquer na relva que ele pulava e virava, mas seu olfato era ruim, e ele não conseguia, sozinho, encontrar os rastros; então, olhava para Milton e corria para onde Milton ia. Mal Milton se movia na direção de um rastro, Bulka já aparecia na sua frente. Eu podia chamar Bulka, bater nele, mas nada disso adiantava. Quando Milton começava a procurar, Bulka jogava-se à sua frente e atrapalhava-o. Eu já queria voltar para casa porque, para mim, a caça já estava perdida, mas Milton, mais esperto do que eu, encontrou uma saída melhor do que a minha para enganar Bulka. Eis o que ele fazia: quando Bulka o ultrapassava correndo, Milton deixava o rastro, virava-se para o outro lado e fingia procurar. Bulka voava na direção indicada por Milton. Milton olhava-me, balançava o rabo e, de novo, seguia pelo verdadeiro rastro. De novo, Bulka chegava mais uma vez correndo até Milton, ultrapassava-o correndo e, de propósito, Milton dava de novo dez passos para o lado, enganava Bulka e, outra vez, levava-me na direção correta. E, assim, durante toda a caçada, Milton enganou Bulka, impedindo-o de estragar tudo. 


\section{A tartaruga}

conto

Certa vez, fui caçar com Milton. Perto da floresta, ele começou a procurar, ergueu o rabo, levantou as orelhas e pôs-se a farejar. Armei a espingarda e fui atrás dele. Pensei que ele estivesse procurando uma perdiz, um faisão ou uma lebre. Mas Milton não foi para a floresta, foi para o campo. Continuei atrás dele, olhando para frente. De repente, vi o que ele estava procurando. À sua frente, corria uma pequena tartaruga, do tamanho de uma chapka. Presa a um longo pescoço, uma cabeça careca, cinza-escuro, estava esticada como um pistilo; a pequena tartaruga mexia suas patas peladas, e seu dorso estava coberto por um casco.

Quando ela viu o cachorro, escondeu as patas e a cabeça, e enfiou-se na relva, de modo que apenas o seu casco podia ser visto. Milton agarrou-a e começou a dar dentadas nela, mas não conseguiu mordê-la porque as tartarugas têm a barriga e as costas cobertas por um casco. Elas têm apenas buracos na frente, atrás e do lado, por onde saem a cabeça, as patas e o rabo.

Tirei a tartaruga de Milton e observei os desenhos de suas costas, o seu casco, e como ela escondia-se nele. Quando seguramos uma tartaruga nas mãos e olhamos dentro do casco, bem lá dentro, como se fosse num porão, vemos uma coisa preta e viva. Joguei a tartaruga sobre a relva e segui adiante, mas Milton não queria deixá-la e carregava-a nos dentes, atrás de mim. De repente, Milton ganiu e largou-a. A tartaruga havia tirado a pata e arranhado-lhe a boca. Ele ficou tão zangado com ela por causa disso que começou a latir e, outra vez, agarrou-a e carregou-a atrás de mim. Mais uma vez, mandei-o soltá-la, mas Milton não me obedeceu. Então, arranquei-lhe a tartaruga e joguei-a. Mas ele não a deixou. E começou a cavar um buraco apressadamente com as patas. E, depois de abrir uma cova, também com as patas jogou a tartaruga nela e enterrou-a.

As tartarugas vivem tanto na terra como na água, como as cobras de água doce e as rãs. Seus filhotes saem dos ovos, que são postos na terra e não são chocados. As tartarugas não chocam seus ovos: tal como os ovos dos peixes, eles próprios se quebram sozinhos, e os filhotes saem. Há tartarugas pequenas, que não passam do 
tamanho de um pires; e há tartarugas grandes, de três $\operatorname{archins}^{136}$ de comprimento e vinte pounds ${ }^{137}$. As tartarugas grandes vivem nos mares.

Na primavera, uma tartaruga põe centenas de ovos. O casco das tartarugas é as suas costelas. Apenas as pessoas e outros seres vivos têm as costelas separadas em seção, mas as costelas das tartarugas juntaram-se, formando o casco. O interessante disso é que, em todos os animais, as costelas ficam dentro do corpo; nas tartarugas, no entanto, elas ficam na parte externa e, sob as costelas, está a carne.

${ }^{136}$ Medida antiga que corresponde a $0,71 \mathrm{~m}$. (N.T.)

${ }^{137}$ Libra, medida equivalente a 0,453 g. (N.T.) 


\section{Bulka e o lobo}

conto

Quando eu saí do Cáucaso, ainda havia guerra lá e, à noite, era perigoso viajar sem escolta.

Eu queria partir de manhã, o mais cedo possível e, por isso, nem me deitei para dormir.

Meu amigo chegou para se despedir de mim, e nós passamos toda a noite e a madrugada sentados na rua da aldeia, na frente de minha khata $^{138}$.

À noite, havia lua e neblina, mas estava tão claro que se podia ler, ainda que não se visse a lua.

De repente, no meio da noite, escutamos, num quintal do outro lado da rua, o grunhido de um porquinho. Um de nós gritou:

— É um lobo estrangulando um porquinho.

Corri para a minha khata, peguei a espingarda carregada e voltei correndo para a rua. Todos estavam de pé, na frente do portão do quintal onde o porquinho grunhia, e gritaram-me:

- Aqui, aqui!

Milton correu atrás de mim, certamente ele pensou que eu ia caçar com a espingarda. E Bulka levantou suas orelhas curtas e agitou-se de um lado a outro, como se estivesse perguntando quem ele deveria abocanhar. Quando cheguei correndo até a cerca, vi do outro lado do quintal, na minha frente, uma fera correndo. Era um lobo. Ele correu na direção da cerca e pulou-a. Posicionei-me e armei a espingarda. Assim que o lobo pulou a cerca na minha direção, apertei o gatilho bem à queima-roupa; mas a espingarda fez "tchic"e não disparou. O lobo não parou e saiu correndo pela rua. Milton e Bulka foram atrás dele. Milton esteve a ponto de pegá-lo, mas percebia-se que ele tinha medo dele; e Bulka, por mais que corresse com suas pernas curtas, não conseguiu alcançá-lo. Nós corremos como loucos atrás do lobo, mas o lobo e os cães sumiram de nossas vistas. Apenas perto de um fosso, no final da aldeia, escutamos latidos e ganidos, e vimos, entre a neblina iluminada pela lua, uma nuvem de poeira e a algazarra dos cães e do lobo. Quando chegamos correndo ao

\footnotetext{
${ }^{138}$ Típica casa ucraniana. Diferentemente da isbá, construída com madeira, a khata é construída com barro e caiada de branco. (N.T.)
} 
fosso, o lobo já não estava mais, e ambos os cães voltaram até nós com os rabos levantados e um ar zangado. Bulka rosnava e empurrava-me com a cabeça; via-se que ele queria contar algo, mas não sabia como.

Examinamos os cães e achamos uma pequena ferida na cabeça de Bulka. Provavelmente ele alcançara o lobo antes do fosso, mas não conseguiu pegá-lo; o lobo deve ter-lhe arreganhado os dentes e, depois, fugido. A ferida não era grande e, portanto, não havia perigo.

Nós voltamos para a khata, sentamo-nos e comentamos sobre o que havia acontecido. Eu estava aflito porque a minha espingarda havia falhado, e pensava apenas se o lobo teria ficado parado no mesmo lugar caso a espingarda tivesse disparado. Meu amigo ficou surpreso, imaginando como o lobo teria entrado no quintal. Um velho cossaco falou que não havia nada de surpreendente naquilo, que não era um lobo, mas uma bruxa, e que ela tinha enfeitiçado a minha espingarda. $\mathrm{E}$, assim, conversávamos sentados. De repente, os cães saíram em disparada, e nós vimos, no meio da rua, bem à nossa frente, novamente aquele mesmo lobo; mas desta vez, com os nossos gritos, ele correu tão rápido que os cães já não conseguiram alcançá-lo.

Depois disso, o velho cossaco ficou totalmente convencido de que aquilo não era um lobo, mas uma bruxa. Eu, no entanto, pensava se aquilo não era um lobo raivoso, porque eu nunca tinha visto nem tinha ouvido dizer que um lobo voltasse para a mesma aldeia de onde havia sido expulso.

Por precaução, coloquei pólvora na ferida de Bulka e toquei-lhe fogo. A pólvora incendiou-se e queimou o local ferido.

Queimei a ferida com pólvora para que a saliva do animal raivoso não fosse logo para o sangue. Se a saliva tivesse penetrado na ferida, e tivesse chegado ao sangue, eu sabia que ela dispersar-se-ia pelo sangue por todo o corpo e, então, nada mais poderia curar Bulka. 
O que aconteceu com Bulka em Piatigorsk ${ }^{139}$

conto

Da aldeia cossaca, eu não fui direto para a Rússia: parei primeiro em Piatigorsk, onde fiquei dois meses. Dei Milton a um caçador cossaco e levei Bulka junto comigo para Piatigorsk.

Piatigorsk é assim chamada porque ela fica na montanha Bechtau. "Bech", em tártaro, significa "piat"140 e "tau" significa "gorá" ${ }^{141}$. Dessa montanha corre água quente e sulfurosa. Essa água é quente como água fervente e, sobre o lugar da montanha por onde ela corre, há sempre vapor, como há vapor sobre o samovar. A cidade inteira é muito alegre. Das montanhas correm fontes quentes e, no sopé dessas montanhas, corre o rio Podkumok. Na montanha, há uma floresta e, à sua volta, há campos. Ao longe, veem-se as grandes montanhas do Cáucaso. Nessas montanhas, a neve nunca derrete, e elas estão sempre brancas, como açúcar. Elbrus é uma grande montanha, e sua cabeça parece feita de açúcar branco; quando o tempo está aberto, ela é vista de qualquer lugar. As pessoas vão às fontes termais para se tratar; e sobre as fontes há caramanchões e alpendres e, em volta delas, há veredas floridas. De manhã tocam música, e as pessoas bebem água ou banham-se e passeiam.

A própria cidade fica na montanha e, no vale, há uma vila. Eu passei algum tempo nessa vila, numa pequena casinha. Essa pequena casa ficava num quintal e, na frente das janelas, havia um pequeno jardim e, nesse jardim, ficavam as abelhas dos donos. Elas não ficavam nos cepos, como na Rússia, mas em colmeias redondas. As abelhas de lá são tão tranquilas que eu e Bulka passávamos todas as tardes no jardim, no meio do colmeial.

Bulka passeava no meio das colmeias, observava as abelhas, farejava, escutava-as zumbir e andava com tanto cuidado em volta delas que ele não as incomodava, e nem elas o picavam.

Certa manhã, eu voltava das termas para casa e sentei-me para beber café no jardim. Bulka começou a coçar as orelhas e a fazer barulho com a coleira. O barulho incomodava as abelhas e eu tirei a coleira de Bulka. Pouco tempo depois, escutei, vindo da cidade das montanhas, um barulho estranho, assustador. Os cães latiam,

\footnotetext{
${ }^{139}$ Nome de uma aldeia cossaca. (N.T.)

${ }^{140}$ Em russo, "piat" significa "cinco". (N.T.)

${ }^{141}$ Em russo, "gorá" significa "montanha". (N.T.)
} 
uivavam, ganiam, as pessoas gritavam, e aquele barulho descia das montanhas e chegava cada vez mais e mais perto de nossa vila. Bulka parou de se coçar, deitou sua grande cabeça com dentes brancos, acomodou sua língua do seu jeito e, tranquilamente, deitou-se ao meu lado. Quando ele ouviu o barulho - como se tivesse entendido o que estava acontecendo - levantou as orelhas, arreganhou os dentes, deu um pulo e começou a rosnar. O barulho estava se aproximando. Parecia que todos os cães da cidade estavam uivando, ganindo e latindo. Fui até o portão para ver o que estava acontecendo, e a dona da minha casa também foi. Perguntei-lhe:

— O que está acontecendo?

Ela respondeu:

- São os condenados que saíram da cadeia para matar os cachorros. Há cachorros em demasia e as autoridades daqui mandaram matar todos os cachorros da cidade.

— Como? Matarão também Bulka se o encontrarem?

— Não, eles têm ordens para não matar cães com coleiras.

Naquele mesmo instante, enquanto eu falava, os condenados já tinham se aproximado do nosso portão.

À frente, iam soldados e, atrás deles, quatro condenados, um algemado à perna do outro. Dois deles carregavam longos ganchos de ferro e, os demais, barras. Na frente do portão, um condenado pegou um vira-lata com o gancho e puxou-o até o meio da rua, e outro condenado começou a bater nele. O cachorrinho gritava terrivelmente, e os condenados gritavam sabe-se lá o quê e riam. Um condenado virou o cachorrinho com o gancho e, quando viu que ele já estava morto, retirou o gancho e começou a olhar se não havia mais um cachorro ainda.

Naquele momento, como fazia com os ursos, Bulka pulou no condenado. Lembrei-me de que ele estava sem a coleira e gritei:

— Bulka, volte! - E gritei aos condenados, para que eles não batessem em Bulka. Mas um deles viu Bulka, soltou uma gargalhada e, agilmente, com o gancho, bateu em Bulka e enganchou-o pela coxa. Bulka tentava se livrar, mas o condenado puxou-o para perto de si e gritou para os outros.

- Matem!

Outro condenado ergueu a barra, e Bulka teria sido morto se ele não tivesse se soltado violentamente, rasgando a pele da coxa. E, com o rabo encolhido, e uma 
ferida ensanguentada na pata, ele entrou voando, todo apressado, pela cancela do portão e, em casa, escondeu-se debaixo de minha cama.

Bulka salvou-se apenas porque a sua pele se rasgou de ponta a ponta naquele mesmo lugar em que o gancho havia penetrado. 
O fim de Bulka e de Milton

conto

Bulka e Milton morreram na mesma época. O velho cossaco não sabia tratar de Milton. Em vez de o levar consigo apenas para caçar pássaros, ele começou a leválo para caçar também javalis. E, num outono, um javali sekatch ${ }^{142}$ rasgou-o todo. Ninguém sabia como costurá-lo, e Milton morreu.

Bulka tampouco viveu muito depois de ter sofrido os golpes dos condenados. Logo após ter sobrevivido aos golpes dos condenados, ele começou a ficar muito triste e a lamber tudo o que encontrava. Lambia as minhas mãos, mas não como antes, quando queria me fazer carinho. Bulka lambia longamente, apoiando a língua com força e, depois, prendia-me com os dentes. Parecia que precisava morder a minha mão, mas ele não queria. Parei de lhe dar a minha mão. Então, ele começou a lamber a minha bota e o pé da mesa e, depois, começou a morder a minha bota e o pé da mesa. Isso durou dois dias e, no terceiro dia, Bulka desapareceu e ninguém o viu nem teve notícias dele.

Não era possível que o tivessem roubado, ou que ele tivesse me abandonado, e isso havia acontecido com ele seis semanas depois de ele ter sido mordido por um lobo. Então, era isso mesmo: o lobo estava raivoso. Bulka ficou raivoso e fugiu. Com ele, ocorreu aquilo que os caçadores chamam de salivação. Dizem que a raiva consiste em cãibras na garganta de animais raivosos. Animais raivosos querem beber, mas não conseguem porque a água provoca cãibras mais fortes ainda. Então, por causa da dor e da sede, eles perdem o controle e começam a morder. Certamente, Bulka começou a sentir essas cãibras quando começou a lamber e, depois, a morder a minha mão e o pé da mesa.

Eu procurava Bulka por toda a parte nos arredores, e perguntava por ele, mas não conseguia saber onde ele havia se metido nem como havia morrido. Se ele tivesse corrido, mordendo as pessoas como fazem os cães raivosos, então eu saberia dele. Mas, provavelmente, Bulka correu para algum lugar longe, e lá morreu sozinho. Os caçadores dizem que quando um cão inteligente sofre de raiva, ele foge para o campo ou para a floresta, onde procura uma planta de que necessita, rola sobre o orvalho, e cura-se sozinho. Provavelmente, Bulka não conseguiu se curar. Ele nunca voltou e desapareceu.

${ }^{142}$ Javali de dois anos, e com afiados e sobressalentes dentes caninos. (N.A.) 
Os pássaros e as redes

fábula

Um caçador armou redes num lago e apanhou muitos pássaros. Os pássaros eram grandes, levantaram a rede e fugiram. O caçador correu atrás dos pássaros. Um camponês viu o caçador correndo e perguntou:

— Para onde é que você está correndo? Será que você acha que se pode pegar pássaros assim, desse jeito?

O caçador respondeu:

— Se fosse só um pássaro, eu não o pegaria, mas agora vou pegar.

Dito e feito. Quando caiu a noite, o sono chamou os pássaros, cada um para o seu lado: um para a floresta, outro para o pântano, outro, ainda, para o campo. Todos caíram no chão junto com a rede, e o caçador pegou-os. 


\section{O olfato}

O ser humano vê com os olhos, ouve com os ouvidos, sente cheiros com o nariz, sente gosto com a língua e sente o tato com os dedos. Alguns homens veem melhor, outros, pior. Um ouve de longe, e outro é surdo. Um tem olfato mais forte e sente cheiros à distância; e outro, ao cheirar um ovo podre, nada sente. Um conhece qualquer coisa apenas tateando-a, e outro tem tato fraco e não consegue distinguir a madeira do papel. Um, só de provar, sente o doce e, outro, engole e não distingue o amargo do doce.

O mesmo ocorre entre os animais. Mas todos os animais têm o olfato mais desenvolvido do que o homem.

Quando quer saber o que é uma coisa, o ser humano olha-a, escuta o barulho que ela faz e, às vezes, cheira-a e prova-a; mas, para conhecer uma coisa, o ser humano precisa, principalmente, apalpá-la.

Para quase todos os animais, no entanto, o mais importante é cheirar a coisa. Cavalo, lobo, cachorro, vaca, urso não conhecem a coisa enquanto não a cheiram.

Quando um cavalo sente medo de alguma coisa, ele bufa para limpar o nariz: assim, sentirá melhor o cheiro e sentirá medo enquanto não cheirar.

O cachorro sempre segue o dono pelo rastro, mas, ao ver o dono, ele assustase, não o reconhece e late até sentir o seu cheiro. Então, percebe que aquilo que, a seus olhos, era amedrontador não passava de seu próprio dono.

Os bois veem outros bois sendo abatidos, ouvem seus mugidos no abatedouro e não entendem nada do que está acontecendo. Mas, se uma vaca ou um boi for ao lugar onde há sangue de outros bois, ao cheirar, ele logo entenderá, começará a mugir, a bater os cascos, e ninguém conseguirá enxotá-lo daquele lugar.

A mulher de um velhinho ficou doente; ele próprio foi ordenhar a vaca. A vaca bufou, viu que não era a sua dona e não deu leite. A mulher mandou o marido vestir o casado dela e cobrir a cabeça com o seu lenço: a vaca deu leite; mas o velho abriu o casaco, a vaca sentiu o seu cheiro e, outra vez, parou de dar leite.

Quando, ao perseguir algum animal, os cães galgos seguem o rastro por ele deixado, eles nunca correm exatamente sobre o rastro, mas a vinte passos de distância dele. Quando um caçador inexperiente quer colocar o cão no rastro do animal, ele 
enfia o nariz do cão no rastro, mas o cão sempre dá um pulo para o lado. Para ele, o rastro cheira tão forte que ele não consegue farejar nada no próprio rastro, e não sabe se o animal correu para trás ou para frente. Ele dá um pulo para o lado, e só quando sente de que direção o cheiro está mais forte é que ele corre atrás do animal. Ele faz como nós fazemos quando nos gritam aos ouvidos: nós nos afastamos e, então, só com a distância, entendemos o que estão nos falando; ou quando aquilo que olhamos está perto demais de nós, nós nos afastamos e, então, enxergamos.

Os cães conhecem uns os outros, e sinalizam uns aos outros pelo odor.

Mais apurado ainda é o olfato dos insetos. A abelha voa direto para a flor de que ela precisa. Os vermes vão na direção da sua folha. O percevejo, a pulga e o mosquito sentem o homem a cem mil passos de distância.

Se são minúsculas as partículas que se desprendem dos objetos e caem sobre o nosso nariz, quão minúsculas não seriam todas aquelas que chegam ao olfato dos insetos?! 
Os cães e o cozinheiro

fábula

Um cozinheiro preparou o almoço; os cães estavam deitados à porta da cozinha. O cozinheiro matou um bezerro e jogou as tripas no quintal. Os cães apanharam-nas, comeram-nas e disseram:

- O cozinheiro é bom: ele cozinha bem.

Pouco depois, o cozinheiro começou a limpar ervilhas, nabos e cebolas, e jogou as cascas. Os cães avançaram, torceram o nariz e disseram:

- Nosso cozinheiro ficou estragado: antes, cozinhava bem, mas, agora, não presta para nada.

Mas foram os donos da casa que comeram e elogiaram o almoço, e não os cães. 
A fundação de Roma

relato histórico

Era uma vez um imperador que tinha dois filhos: Numitor e Amulius. No seu leito de morte, o imperador disse aos filhos:

- Como vocês querem fazer a partilha entre os dois? Quem ficará com o reino e quem herdará a minha fortuna?

Numitor ficou com o reino e Amulius ficou com a fortuna. Depois de ter ficado com a fortuna, Amulius passou a ter inveja porque seu irmão era rei, e começou a mimosear os soldados, a convencê-los a expulsar Numitor e a coroá-lo, ele, Amulius, imperador. E assim os soldados fizeram: Amulius tornou-se imperador. Numitor tinha uma filha. E essa filha deu à luz gêmeos: dois meninos. Ambos eram fortes e bonitos.

Amulius temia que o povo gostasse dos gêmeos e que, quando eles crescessem, coroassem-nos imperadores. Ele mandou chamar seu criado Faustinus e disse-lhe:

- Pegue os dois meninos e jogue-os no rio.

O nome desse rio era Tibre.

Faustinus colocou as crianças num berço, levou-as até a margem do rio e deixou-as lá. Faustinus pensou que elas morreriam sozinhas. Mas o Tibre transbordou, invadiu a margem, levantou o berço, carregou-o e deixou-o aos pés de uma árvore alta. Quando a noite caiu, uma loba chegou e começou a alimentar os gêmeos com o seu próprio leite.

Os meninos cresceram, ficaram grandes, bonitos e fortes. Eles viviam na floresta, perto da cidade onde Amulius morava, e aprenderam a matar feras e alimentar-se de sua carne. O povo conheceu-os e amou-os por sua beleza. O maior chamava-se Romulus e, o menor, Remus.

Certa vez, os pastores de Numitur e de Amulius pastavam o gado perto da floresta e começaram a brigar; os pastores de Amulis roubaram o rebanho de Numitur. Os gêmeos viram aquilo, correram atrás dos pastores, alcançaram-nos e recuperaram todo o gado. 
Os pastores de Numitor ficaram bravos com os gêmeos, escolheram um momento em que Romulus não estava, agarraram Remus, levaram-no para a cidade, até Numitor, e disseram:

Dois irmãos apareceram na floresta, pegaram o gado e vivem de rapina. Nós pegamos um deles e trouxemo-lo.

Numitor mandou que conduzissem Remus ao imperador Amulis. Amulis disse:

- Eles ofenderam os pastores de meu irmão, deixem que meu irmão os julgue.

Remus foi novamente levado até Numitor. Numitor chamou-o para perto de si e perguntou-lhe:

— De onde você veio, e quem, afinal, é você?

Remus respondeu-lhe:

- Somos dois irmãos; quando éramos pequenos levaram-nos, num berço, para as margens do rio Tibre e, lá, fomos alimentados por animais ferozes e por pássaros. Crescemos naquele lugar. E, para saber quem somos, ainda temos o nosso berço. Nele, há fitas de cobre e, nelas, há alguma coisa inscrita.

Numitor ficou surpreso e pensou se aqueles não seriam os seus netos. Ele ficou com Remus e chamou Faustinus para interrogá-lo.

Enquanto isso, Romulus estava procurando o seu irmão, mas não conseguia encontrá-lo em lugar nenhum. Quando os pastores lhe disseram que seu irmão havia sido levado para a cidade, ele pegou o berço e foi atrás do irmão. Faustinus, então, reconheceu o berço, e contou ao povo que aqueles eram os netos de Numitor que Amulius havia tentado afogar. Então, com raiva, o povo matou Amulis, e Romulus e Remus foram coroados imperadores. Mas Romulus e Remus não queriam viver naquela cidade, e nela deixaram reinando o seu avô Numitor. Eles voltaram para o mesmo lugar, aos pés da árvore onde foram alimentados pela loba, perto do rio Tibre, e lá, naquele lugar, construíram uma nova cidade: Roma. 
Deus diz a verdade, mas não a diz logo

história verdadeira

$\mathrm{Na}$ cidade de Vladímir vivia um jovem mercador chamado Aksíonov. Ele tinha duas vendas e uma casa.

Aksíonov tinha belos cabelos castanhos encaracolados e era, acima de tudo, brincalhão e bom cantor. Desde jovem, ele bebia muito, e quando ficava bêbado só queria brigar; mas, depois que se casou, parou de beber e só às vezes tinha uma recaída.

Certo verão, Aksíonov foi para uma feira, na cidade de Níjni ${ }^{143}$. Durante as despedidas da família, sua mulher pediu-lhe:

— Ivan Dmítrievitch, não vá hoje, eu tive um sonho ruim com você:

Aksíonov riu e disse:

— Você ainda tem medo que eu volte a beber na feira.

A mulher disse:

- Nem eu mesma sei por que tenho medo, mas o sonho foi muito ruim: vi você voltando da cidade, tirando a chapka e, então, vi a sua cabeça toda grisalha.

Aksíonov riu.

— Então, é bom presságio. Veja, se eu vender bem, trarei presentes caros para você.

Ele despediu-se da família e foi embora.

No meio do caminho, Aksíonov encontrou um mercador conhecido seu e, juntos, pararam para dormir. Ambos tomaram chá, e deitaram-se em dois quartos contíguos. Aksíonov não era muito dorminhoco; acordou no meio da noite e, para aproveitar o tempo fresco durante a viagem, acordou o cocheiro e mandou-o atrelar o cavalo. Depois, voltou para os fundos da isbá, pagou o dono e foi embora.

Ele andou quarenta verstas, parou novamente para alimentar os cavalos numa paragem e, no almoço, sentou-se na soleira da porta, mandou preparar o samovar, pegou o violão e começou a tocar. De repente, na paragem, aproximou-se uma troica com sinos e, da carruagem, saiu um funcionário com dois soldados. Eles aproximaram-se de Aksíonov e perguntaram:

— Quem? De onde?

${ }^{143}$ Cidade às margens dos rios Volga e Oka, também conhecida como Górki. (N.T.) 
Aksíonov contou tudo certinho e perguntou-lhes:

— Não gostariam de beber chá comigo?

Mas o funcionário insistiu no interrogatório:

- Onde você dormiu na noite passada? Você estava sozinho ou com um mercador? Você viu o mercador de manhã? Por que você saiu cedinho da paragem?

Aksíonov ficou surpreso com aquelas tantas perguntas que lhe faziam, contou tudo o que havia acontecido e disse:

— Por que vocês estão me interrogando desse jeito? Não sou ladrão, não sou nenhum bandido. Estou viajando por causa dos meus negócios. Então, chega de perguntas.

Mas, o funcionário chamou o soldado e disse:

- Sou chefe de polícia, e interrogo-o porque o mercador que pernoitou com você na noite passada foi assassinado com faca. Mostre-me suas coisas. Vocês, revistem-no.

Eles entraram na isbá, pegaram a mala e a trouxa de Aksíonov e começaram a abrir e a vasculhar tudo. De repente, o policial tirou uma faca da trouxa e gritou:

- De quem é essa faca?

Aksíonov olhou, viu a faca suja de sangue que saíra de sua trouxa e ficou assustado.

— E por que esse sangue na faca?

Aksíonov tentou responder, mas não podia pronunciar nenhuma palavra.

— Eu...eu não sei...eu...a faca...eu...não é minha...

— Então, o policial falou:

- Hoje de manhã encontramos o mercador morto sobre a cama. Ninguém, além de você, poderia ter feito aquilo. A porta da isbá estava fechada por dentro e, dentro da isbá, não havia ninguém, exceto você. Eis uma faca ensanguentada na sua trouxa e, além disso, basta olhar para você. Diga como você o matou e quanto dinheiro roubou.

Aksíonov jurou por Deus que não havia feito aquilo, que não havia visto mais o mercador depois que ambos beberam chá, que só tinha os seus 8.000 rublos, que a faca não era sua. Mas sua voz estava entrecortada, seu rosto estava pálido e ele não parava de tremer de medo, como se fosse o culpado.

O funcionário chamou os soldados, mandou amarrar Aksíonov e levá-lo para a telega. Quando o jogaram com as pernas amarradas na telega, Aksíonov persignou-se 
e começou a chorar. Pegaram seus pertences e seu dinheiro, mandaram-no para a cadeia numa cidade vizinha. Foram até Vladímir para saber que tipo de pessoa era Aksíonov, e todos os mercadores da cidade disseram que, desde jovem, ele bebia e farreava, mas que era uma boa pessoa. Então, começou o julgamento. Julgaram-no por ter matado um mercador da cidade de Riazán ${ }^{144}$, e por ter roubado 20.000 rublos.

Sua mulher estava desesperada pelo marido, e não sabia o que pensar. As crianças eram ainda pequenas, e ela ainda amamentava uma delas. Ela pegou todos os filhos e levou-os consigo até a cidade onde seu marido estava detido na cadeia. No começo, não a deixaram entrar, mas depois conseguiu permissão dos chefes e foi levada até o marido. Quando ela o viu em roupas de prisioneiro, acorrentado, junto com bandidos, desmaiou e ficou muito tempo desacordada. Depois, colocou as crianças ao seu redor, sentou-se ao lado do marido e começou a lhe falar de assuntos domésticos, e a lhe perguntar sobre tudo, sobre o que havia-lhe acontecido. Ele contou-lhe tudo. Ela perguntou:

- O que vai acontecer agora?

Ele respondeu:

— Precisamos pedir ao tzar. Como pode um inocente perecer?

A mulher disse-lhe que ela já havia enviado um pedido ao tzar, mas que o pedido não havia chegado a ele. Aksíonov não disse nada e baixou a cabeça. Então, a mulher disse:

- Não é por acaso - lembra-se? - que sonhei que você tinha ficado grisalho. Agora é verdade: você ficou grisalho de tanto sofrer. Você não deveria ter saído naquele dia.

Ela começou a passar a mão na cabeça dele, e disse:

— Vânia ${ }^{145}$, meu coração, conte a verdade à sua mulher: não foi você que fez aquilo?

Aksíonov disse:

- Até você duvida de mim! - E cobriu o rosto com as mãos e começou a chorar. Depois, chegou um soldado e disse que a mulher e as crianças tinham de sair dali. E, pela última vez, Aksíonov despediu-se da família.

Quando a mulher saiu, Aksíonov começou a se lembrar de tudo o que havia sido dito. Quando se lembrou de que a sua mulher também duvidava dele e de que ela

\footnotetext{
${ }^{144}$ Cidade às margens do rio Oka. (N.T.)

${ }^{145}$ Diminutivo de Ivan. (N.T.)
} 
perguntara-lhe se ele havia matado o mercador, ele disse para si mesmo: talvez ninguém, além de Deus, possa saber a verdade, apenas a Ele devo pedir, e apenas d'Ele devo esperar um milagre. Desde então, Aksíonov parou de mandar pedidos, deixou de contar com ajuda, e só rezava a Deus.

Aksíonov foi condenado, castigado com chibatadas, e enviado para trabalhos forçados. Assim foi feito.

Foi chicoteado e, depois que as feridas cicatrizaram, mandaram-no junto com outros prisioneiros para a Sibéria.

$\mathrm{Na}$ Sibéria, Aksíonov viveu vinte e seis anos como galé ${ }^{146}$. Seus cabelos começaram a ficar brancos como a neve, sua barba cresceu longa, rala e grisalha. Toda a sua alegria havia desaparecido. Ele ficou corcunda, começou a andar devagar, a falar pouco, nunca ria e sempre rezava a Deus.

No campo de concentração, Aksíonov aprendeu a costurar botas e, com o dinheiro de seu trabalho, comprou um almanaque religioso e lia-o quando havia luz no campo de concentração; e, nos dias de festas religiosas, ele ia à igreja do campo de concentração, lia o Ato dos Apóstolos e cantava no coro, pois sua voz ainda era boa. O chefe daquele lugar gostava de Aksíonov porque ele era humilde, e seus companheiros do campo chamavam-no de "velhinho" e de "homem de Deus". Quando havia algum pedido a ser feito pelos presos, os companheiros de Aksíonov sempre o mandavam falar com o chefe, e quando havia brigas entre os prisioneiros, eles sempre procuravam Aksíonov para julgar.

Aksíonov não recebia cartas de casa, e não sabia se sua mulher e filhos estavam vivos.

Certa vez, novos condenados chegaram ao campo de concentração. À noite, todos os antigos presos reuniram-se ao redor dos novatos, e começaram a perguntarlhes de que cidade, ou aldeia, cada um deles era, e o que cada um havia feito. Aksíonov também se sentou na tarimba com os recém-chegados e, cabisbaixo, escutava o que contavam. Um dos novos prisioneiros era alto, um saudável velho de sessenta anos, com barba grisalha e curta. Ele contou por que o haviam prendido:

— É isso mesmo, irmãos, pegaram-me por nada. Eu desamarrei um cavalo do trenó de um cocheiro. Pegaram-me e disseram:

- Você roubou.

\footnotetext{
${ }^{146}$ Pessoa sentenciada a trabalhos forçados. (N.T.)
} 
Eu respondi:

- Eu apenas precisava chegar o mais rápido possível, e só soltei o cavalo. E, além disso, o cocheiro é meu amigo. Está tudo certo.

— Não - disseram —, você roubou. Só que eles não sabiam o que, nem onde, eu havia roubado. Algumas coisas aconteceram, eu deveria estar aqui há muito, mas não me pegaram e, agora, não é justo que me enterrem aqui. Mas é o seguinte: posso estar na Sibéria, mas isso não vai durar muito.

— E você, de onde é? - perguntou um dos prisioneiros.

- Somos mercadores lá da cidade de Vladímir. Meu nome é Makar, e meu patronímico é Semiónovitch.

Aksíonov levantou a cabeça e perguntou:

- Será, Semiónovitch, que você ouviu falar em, Vladímir, sobre a família Aksíonov, eles são mercadores. Será que ainda estão vivos?

- Claro que ouvi falar! São mercadores ricos, apesar de o pai estar na Sibéria. Assim como nós, também pecadores. E você, meu bom velhinho, por que está aqui?

Aksíonov não gostava de falar de sua desgraça; ele suspirou e disse:

- Pelos meus pecados, já vinte e seis anos de trabalhos forçados.

Makar Semiónovitch perguntou:

— Mas que pecados?

Aksíonov respondeu:

- Os que eu cometi.

E ele não quis mais falar. Mas seus companheiros contaram aos recémchegados como Aksíonov havia ido parar na Sibéria. Contaram como, na estrada, alguém matara um mercador e ocultara a faca na trouxa de Aksíonov e como, por causa disso, condenaram-no injustamente.

Depois de escutar toda a história, Makar Semiónovitch olhou para Aksíonov, bateu com as mãos nos joelhos e disse:

— Que milagre! Mas que milagre! Como você envelheceu, meu velho!

Começaram a lhe perguntar por que ele estava tão surpreso, e de onde ele conhecia Aksíonov; mas Makar Semiónovitch não respondeu, apenas disse:

- Milagre, amigos, onde é que fomos nos encontrar!

E, depois de escutar essas palavras, Aksíonov chegou a pensar se Makar Semiónovitch não conhecia o assassino do mercador. Ele perguntou: 
— Semiónovitch, terá você ouvido falar sobre esse assunto, ou já terá você me visto antes?

- Claro que ouvi falar! O mundo está cheio de rumores. Há muito que isso aconteceu: tudo aquilo que ouvi já esqueci — disse Makar Semiónovitch.

- Talvez você tenha ouvido falar sobre o assassino do mercador perguntou Aksíonov.

Makar Semiónovitch riu e disse:

- É claro que quem o matou foi aquele que carregava a faca na trouxa. Mesmo que alguém tivesse escondido a faca na sua trouxa, sem provas não há ladrão. E como seria possível esconder a faca na sua trouxa? Pois ela não estava embaixo da sua cabeça? Você teria percebido.

Assim que escutou aquelas palavras, Aksíonov começou a pensar que aquele mesmo homem havia assassinado o mercador. Aksíonov levantou-se e saiu. Ele não conseguia pregar os olhos durante toda a noite. Foi tomado por uma angústia, e começou a repassar tudo em imagens: sua mulher estava do mesmo jeito que era quando o acompanhara para se despedir dele na última vez que ele se dirigiu à feira. Viu-a como se ela estivesse viva, viu o seu rosto, os seus olhos, e ouviu-a falar com ele, e também rir. Depois, imaginou seus filhos, como eles eram pequenos naquela época: um, com um casaquinho e, o outro, mamando. E lembrou-se de como ele próprio era: alegre e jovem. Lembrou-se de como estava sentado na varanda, na soleira da porta, de onde o pegaram, e de como ele tocava violão, e de como a sua alma era alegre naquele tempo. Lembrou-se também do cadafalso em que havia sido chicoteado, dos carrascos, do povo ao redor, das correntes, dos prisioneiros, dos 26 anos de sua vida de trabalhos forçados, e de sua velhice. E uma angústia tão grande invadiu-o que ele pensou em se matar com as próprias mãos.

"E tudo isso por causa daquele maldito" — pensou Aksíonov.

E um ódio tão grande por Makar Semiónovitch cresceu dentro dele que ele estava disposto a tudo para se vingar dele. Aksíonov rezou a noite toda, mas não conseguiu se acalmar. No dia seguinte, não se aproximou de Makar Semiónovitch, e sequer olhou para ele.

Assim se passaram duas semanas. À noite, a angústia que Aksíonov sentia por não poder fazer nada o impedia de dormir.

Certa noite, ele começou a andar pelo campo de concentração e viu terra caindo debaixo de uma tarimba. Parou para ver o que era. De repente, Makar 
Semiónovitch surgiu de debaixo da tarimba e olhou com medo para Aksíonov. Aksíonov tentou passar para não o ver, mas Makar agarrou-o pelo braço e contou-lhe como ele cavara um túnel sob as paredes, e como, todos os dias, enchia de terra os canos das botas e esvaziava-os fora, quando era levado para os trabalhos forçados. Ele disse:

— Mas, fique calado, meu velho, tirarei você daqui também. Se você abrir a boca, serei chicoteado até sangrar e não o perdoarei, vou matá-lo.

Quando Aksíonov viu aquele maldito, começou a tremer de raiva dos pés à cabeça, puxou o seu braço das mãos de Makar, e disse:

— Não há razão para eu sair daqui, e nem para você me matar, pois há muito que você já me matou. Delatá-lo ou não delatá-lo? Só Deus é quem sabe.

No dia seguinte, quando foram buscar os prisioneiros para levá-los para os trabalhos forçados, os soldados perceberam que Makar havia mexido com terra, começaram a vasculhar o campo e encontraram um buraco. O chefe chegou e começou a interrogar todo mundo:

- Quem cavou o buraco?

Todos negaram. E, aqueles que sabiam não delataram Makar Semiónovitch porque também sabiam que aquilo os levaria a serem açoitados até quase a morte. Então, o chefe virou-se para Aksíonov. Ele sabia que Aksíonov era uma pessoa justa, e disse:

— Você, velho, não mente. Diga-me, perante Deus, quem fez isto.

Makar Seminóvitch estava lá, de pé, como se nada tivesse acontecido; ele olhava para o chefe, mas não olhava para Aksíonov. As mãos e os lábios de Aksíonov tremiam e, durante muito tempo, ele não conseguiu pronunciar uma palavra sequer.

Ele pensou: "Se eu não o delatar, meu perdão não terá sentido. Que ele pague pelo martírio que me causou. Se eu o denunciar, ele será açoitado até morrer. E se eu estiver enganado a seu respeito? Que alívio eu sentiria?"

O chefe disse mais uma vez:

- Vamos, velho, diga logo a verdade: Quem cavou o buraco?

Aksíonov olhou para Makar Seminóvitch e disse:

— Não vi e não sei nada.

Assim, nunca souberam quem havia cavado o buraco. 
$\mathrm{Na}$ noite seguinte, quando Aksíonov se deitou e começou a cochilar, escutou alguém se aproximar e sentar-se aos pés da tarimba. Ele olhou no escuro e reconheceu Makar.

Aksíonov perguntou:

— O que mais você quer de mim? O que está fazendo aqui?

Makar Seminóvitch permaneceu calado. Aksíonov levantou-se e disse:

- O que você quer? Saia, ou eu chamo o guarda!

Makar Seminóvitch inclinou-se perto de Aksíonov e cochichou:

- Perdoe-me, Ivan Dmítrievitch!

Aksíonov perguntou:

— Perdoá-lo por quê?

- Eu matei o mercador, enfiei a faca na sua trouxa. E eu queria matar você também, mas começaram a fazer barulho no quintal. Então, meti a faca na sua trouxa e fugi pela janela.

Aksíonov continuou calado, sem saber o que dizer. Makar Seminóvitch desceu da tarimba, ajoelhou-se no chão e disse:

- Ivan Dmítrievitch, perdoe-me, perdoe-me pelo amor de Deus. Eu confessarei que matei o mercador e você será perdoado. Você vai voltar para casa.

Aksíonov disse:

— Falar é fácil, mas suportar é difícil! Para onde ir agora? Minha mulher está morta, meus filhos esqueceram-se de mim; não tenho para onde ir.

Makar Seminóvitch continuou ajoelhado, batia com a cabeça no chão, e disse:

- Ivan Dmítrievitch, perdoe-me! Quando me bateram com o chicote foi mais fácil do que olhar para você agora... E você ainda teve pena de mim, não me delatou. Perdoe-me, pelo amor de Cristo! Por favor, perdoe o meu maldito crime.

E ele desatou a chorar.

Quando Aksíonov percebeu que Makar Seminóvitch estava chorando, ele também começou a chorar e disse:

- Deus vai perdoar você; talvez eu seja cem vezes pior do que você!

E, de repente, Aksíonov sentiu sua alma mais leve. Ele parou de sentir saudades de casa, e não quis mais sair do campo de concentração, pensava apenas no momento em que a sua última hora chegaria.

Makar Seminóvitch não obedeceu Aksíonov e confessou a sua culpa. Quando deram ordem para soltar Aksíonov, ele já estava morto. 


\section{Cristais}

Se despejarmos sal na água e a mexermos, o sal começará a se dissolver e, assim, dissolver-se-á na água até não vermos mais sal; mas, se despejarmos mais e mais sal, no fim ele deixará de se dissolver e, por mais que mexamos, um pó branco permanecerá na água. A água fica saturada de sal e não consegue mais absorvê-lo. Mas, se aquecermos a água, ela absorverá mais, e o sal que não foi dissolvido na água fria será dissolvido na água quente. Mas, se despejarmos mais sal, então nem a água quente poderá absorvê-lo. E, se aquecermos a água mais ainda, então a própria água transformar-se-á em vapor, e sobrará ainda mais sal. Assim, para tudo o que for solúvel em água, a água tem um limite e, acima dele, ela não poderá mais dissolver. A água dissolve tudo mais facilmente quando ela está quente do que quando está fria, mas, apesar disso, assim que a água ficar saturada, ela não aceitará mais sal. A substância permanece tal como ela é, e a água transforma-se em vapor.

Se saturarmos a água com salitre em pó, e depois acrescentarmos ainda mais salitre, e se aquecermos a água, e se não mexermos nela e se a deixarmos esfriar, o excesso de salitre não se depositará em forma de pó no fundo, mas formará colunas de seis faces, e essas colunas depositar-se-ão no fundo e nas laterais da panela, uma ao lado da outra. Se saturarmos a água com salitre em pó e a deixarmos em um lugar quente, a água evaporar-se-á, e o excesso de salitre também formará colunas de seis faces.

Se saturarmos a água com sal comum, se a aquecermos e se a deixarmos evaporar, a água evaporar-se-á, e o excesso de sal restará não em forma de pó, mas de cubos. Se saturarmos a água com salitre e sal comum, o excesso de salitre e de sal não se misturarão, mas depositar-se-ão, cada qual à sua maneira: o salitre, em pequenas colunas e o sal, em cubos.

Se saturarmos a água com cal ou com outro sal ou, ainda, com qualquer outra substância, quando a água se evaporar, os elementos depositar-se-ão à sua maneira: um, em pequenas colunas de três faces; outro, em colunas de oito faces; outro, em pequenos tijolos; outro, em estrelas, cada qual a seu modo. Essas diferentes figuras estão presentes em todos os corpos sólidos. Algumas vezes elas podem ser grandes, do tamanho de uma mão; encontramos pedras assim na terra. Outras vezes, as figuras 
são tão pequenas que, a olho nu, não podemos enxergá-las; mas cada corpo tem a sua figura.

Se, quando a água está saturada de salitre, e, nela, as figuras começam a se formar, e se quebrarmos uma extremidade da figura com uma agulha, novamente neste mesmo lugar surgirão novas partículas de salitre, e, novamente, elas reconstituirão a extremidade quebrada, exatamente como ela dever ser, em pequenas colunas de seis faces. O mesmo ocorre com o sal, ou com qualquer outra substância. Todas as pequenas partículas movem-se e juntam-se no lugar correto.

O mesmo ocorre quando a água se transforma em gelo.

Um floco de neve voa, e nele não se vê figura alguma; mas quando ele cai sobre qualquer coisa escura e fria como um pano de lã, ou um pedaço de pele, nele, podem-se distinguir figuras: uma pequena estrela ou uma tabuinha de seis ângulos. Nos vidros, o vapor não se congela aleatoriamente, mas quando começa a se congelar, ele se dispõe rapidamente no formato de pequenas estrelas.

O que é o gelo? O gelo é água fria e sólida. Quando a água líquida se transforma em água sólida, ela forma figuras, e dela se desprende o calor. O mesmo acontece com o salitre: ao abandonar o estado líquido, ele forma figuras sólidas, e dele se desprende o calor. O mesmo ocorre com o sal e com o ferro fundido quando este passa de líquido a sólido. Quando qualquer matéria passa do estado líquido ao estado sólido, dela emana calor, e ela forma figuras. Mas, quando de sólida, a matéria transforma-se em líquida, ela absorve o calor, dela emana frio, e as figuras se desfazem.

Peguemos ferro fundido e deixemo-lo esfriar; peguemos massa quente e deixemo-la esfriar; peguemos cal extinta e deixemo-la esfriar: o calor emanará. Peguemos gelo e deixemo-lo derreter: o frio emanará. Peguemos salitre, sal, ou qualquer substância solúvel em água e dissolvemo-la em água: o frio emanará. Para congelar o sorvete, coloca-se sal na água. 


\section{O lobo e a cabra}

fábula

Um lobo viu uma cabra pastando numa montanha rochosa, e era-lhe impossível alcançá-la. Ele, então, perguntou-lhe:

— Você não gostaria de descer? Aqui, neste lugar onde estou, é mais plano, e a grama para o seu pasto é muito mais doce.

Mas a cabra disse:

- Não é por isso que você, lobo, pede-me para descer. Você não está preocupado com o que eu vou comer, mas com o que você vai comer. 


\section{Polícrates de Samos}

relato histórico

Havia um governante grego chamado Polícrates. Ele estava sempre feliz com tudo. Ele havia conquistado muitas cidades e ficou muito rico. Polícrates relatou em uma carta ao seu amigo Amásis, faraó do Egito, toda a sua vida feliz. Amásis leu a carta e enviou a Polícrates a seguinte resposta:

“É agradável conhecer o sucesso de um amigo. Mas a sua felicidade não me agrada. Creio que, para que houvesse contraste, seria melhor que uma pessoa tivesse sorte em um empreendimento, e que não tivesse sorte em outro. Ouça-me, e faça o que eu lhe digo: pegue o que de mais precioso você possui, e jogue-o em qualquer lugar onde ninguém possa encontrá-lo. E, assim, você terá felicidade e infelicidade, alternadamente."

Polícrates leu e seguiu o conselho do amigo. Ele fez o seguinte: ele tinha um anel precioso; pegou esse anel, juntou muitas pessoas e, com elas, subiu em um barco. Depois, ordenou que fossem para o mar. E, quando já estavam longe, atrás das ilhas, então, na presença de todos, ele jogou o anel ao mar e voltou para casa.

Cinco dias depois, um pescador teve a ocasião de apanhar um peixe muito grande e bonito, e resolveu dá-lo ao governante. Ele foi ao pátio de Polícrates e, quando Polícrates apareceu, o pescador disse:

- Polícrates, eu pesquei este peixe e trouxe-o para você porque um peixe tão belo como este apenas um governante pode saborear.

Polícrates agradeceu ao pescador e convidou-o para almoçar com ele. $\mathrm{O}$ pescador entregou-lhe o peixe e acompanhou o governante. Quando os cozinheiros abriram o peixe, acharam aquele mesmo anel que Polícrates havia jogado ao mar.

Quando os cozinheiros levaram o anel para Polícrates e contaram-lhe como eles o haviam encontrado, Polícrates escreveu outra carta a seu amigo Amásis, do Egito, descrevendo-lhe como ele havia jogado o anel, e como o haviam encontrado. Depois de ler a carta, Amásis pensou: isso é um mau sinal; está claro que não se pode fugir do destino. Melhor será me separar de meu amigo para que, mais tarde, eu não sinta pena dele. E mandou dizer a Polícrates que a amizade entre ambos havia chegado ao fim. 
Naquele tempo havia um homem chamado Oroites. Esse tal Oroites estava bravo com Polícrates, e queria arruiná-lo. Ele inventou o seguinte estratagema: escreveu para Polícrates que o imperador Cambises o havia ofendido, que queria matá-lo, e que ele, Oroites, tinha de fugir. Mas nada disso era verdade. Eis a carta que ele inventou: "Possuo grandes riquezas, mas não sei onde viver. Acolha-me junto com a minha riqueza e, então, seremos os mais poderosos governantes. Mas, se você não acreditar que possuo tanta riqueza, envie qualquer pessoa para comprovar.

Polícrates enviou o seu criado para comprovar se era verdade que Oroites possuía tamanha riqueza. Quando o criado chegou para ver o tesouro, Oroites enganou-o: carregou vários barcos com pedras e cobriu-os, até a borda, com ouro.

Quando o criado de Polícrates viu aqueles barcos, acreditou que eles estavam cheios de ouro até a borda, e contou tudo a Polícrates.

Então, Polícrates quis, ele próprio, ir até Oroites para ver os seus tesouros. Naquela mesma noite, a filha de Polícrates sonhou que seu pai estava pendurado no ar. A filha pediu ao pai que não fosse até Oroites; mas Polícrates zangou-se e disselhe que não a deixaria se casar se ela não se calasse imediatamente. Sua filha, então, disse:

— Eu ficaria feliz em não me casar se você não fosse até Oroites: temo que lhe aconteça alguma desgraça.

O pai não deu ouvidos à filha e foi embora. Quando ele chegou, Oroites prendeu-o e enforcou-o. E, dessa maneira, o sonho da filha de Polícrates tornou-se realidade.

Assim aconteceu, tal qual Amásis previra: a grande sorte de Polícrates terminou em uma desgraça ainda maior. 
CAPÍTULO III 


\section{CAPÍTULO III}

Se os textos das Cartilhas têm algum valor, ele consiste na simplicidade, na clareza do desenho e do traço.

Lev N. Tolstói

\section{Observações gerais sobre a tradução}

\section{I - Reprodução de enunciações}

Nos Contos da Nova Cartilha, Tolstói, ou o seu editor, segue uma das duas opções de regras fornecidas pelas normas da gramática russa para o caso de reprodução de enunciações: o discurso direto é, nos Livros de Leitura, indicado no corpo do texto, precedido de dois pontos e de aspas. Em minha tradução, no caso do discurso direto em diálogos, optei pela abertura de parágrafo e pelo travessão, regra igualmente possível na gramática russa, como no exemplo abaixo, extraído do conto Праведный судья, оu "O juiz justo" 147 :

[...] Баукас подал ему и хотел ехать дальще, но калека уцепился ему за платье. "Что тебе нужно?» - спросил Бауакас. - Разве я не дал тебе милостыню?» - «Милостыню ты дал, - сказал калека, но ещё сделай милость - довези меня на твоей лошади до площади, а то лошади и верблюды как бы не раздавили меня». Баукас посадил калеку сзади себя и довез его до площади. На площади Бауакас остановил лошадей. Но нищий не слезал. Бауакас сказал: «Что ж сидишь, слезай, мы приехали.» А нищий сказал: «Зачем слезать, - лошадь моя; а не хочешь добром отдать лошадь, пойдём к судье». Народ собрался вокруг них и слушал, как они спорили; все закричали: «Ступайте к судье, он вас рассудит».

—O que você quer? — perguntou Báuakas. Eu já não lhe dei esmola?

- Esmola você deu - disse o aleijado -, mas conceda-me uma graça: leve-me em seu cavalo até a praça, pois os cavalos e os camelos podem me atropelar.

Báuakas acomodou o aleijado atrás de si e levou-o até a praça. Na praça, Báuakas parou o cavalo. Mas o mendigo não desceu. Báuakas, então, disse:

${ }^{147}$ Todos os contos citados neste capítulo pertencem ao Terceiro Livro de Leitura. 
—O que você está esperando? Desça, já chegamos.

Mas o mendigo respondeu:

- Descer para quê? O cavalo é meu e, se você não quiser entregá-lo de bom grado, iremos ao juiz. As pessoas juntaram-se ao redor deles e escutaram toda a discussão. Todos gritavam:

— Vão até o juiz, ele decidirá.

Também no original russo, pensamentos, sentimentos, desejos e exclamações de personagens encaixam-se no corpo do texto:

[...] Долго я не мог понять, но, наконеи, взглянул на потолок и увидал - клоп лез по потолку; как только он дополз вровень с кроватью, он отцепился от потолка и упал на меня. «Нет, - подумал я, - вас не перехитришь, надел иубу и вышел на двор.

Em casos como esse, a exemplo do original, na tradução conservou-se a frase no corpo do texto, precedida de dois pontos e/ou de aspas:

Durante muito tempo, não consegui dormir mas, finalmente, bati os olhos no teto e vi um percevejo andando; assim que ele chegou bem acima da cama, desgrudou do teto e pulou em mim. "Não-pensei eu-vocês são mais astutos." Peguei meu casaco de pele e fui para fora. Trecho extraído de Kлonbl, ou "Os percevejos"

O mesmo procedimento foi adotado em casos em que o personagem fala consigo:

Когда он вспомнил, что жена тоже подумала на него и спрашивала его, он ли убил купиа, он сказал себе: «Видно, кроме Бога, никто не может знать правды, и только Его надо просить и от нЕго только ждать милость». И с тех пор Аксёнов перестал подавать прочения, перестал надеяться и только молился Богу.

[...] Quando ele se lembrou de que a sua mulher também duvidava dele, e que ela perguntara-lhe se ele havia matado o comerciante, ele disse para si mesmo: "Talvez ninguém, além de Deus, possa saber a verdade, e apenas a Ele eu devo pedir e apenas d'Ele devo esperar um milagre." Desde então, Aksionov deixou de mandar pedidos, deixou de contar com ajuda e só rezava a Deus.

Extraído de Бог правду видит да не скоро скажет, ou "Mais cedo ou mais tarde Deus diz a verdade" 
Ao contrário do texto original, à fala do personagem, ainda que única e isolada, abriu-se novo parágrafo, com travessão:

Царь сказал: «Дурно же я отплатил соколу: он спас мне жизнь, а я убил его».

$O$ rei disse:

- Paguei o bem com o mal ao me vingar do falcão: ele salvou a minha vida e eu o matei.

Extraído de Царь и сокол, ou "O rei e o falcão"

Resumindo, novos parágrafos foram criados: em diálogos, a cada mudança de interlocutor, bem como em frases isoladas, quando precedidas de verbos dicendi. Frases que exprimem pensamentos, quaisquer tipos de sentimentos, conclusões, etc., foram conservadas no corpo do texto, antecedidas de dois pontos e/ou de aspas.

Esses recursos gráficos - como a frequente mudança de linha para indicar a fala dos personagens e o uso do travessão - pareceram-me mais apropriados, sobretudo para textos infantis, porque, visualmente, o texto espalha-se com maior harmonia pela página, o que torna a leitura mais agradável.

Em seus Livros de Leitura, Tolstói não usa, ou só o faz raramente, o discurso indireto, preferindo a reprodução textual da fala dos personagens, concedendo-lhes voz própria. Podemos, assim, concluir que, nesses livros, os personagens estão sempre vivos para o leitor, característica importante quando nos referimos à literatura infantil, em que certa natureza teatral é desejável e bem-vinda.

Os textos de Tolstói não têm apenas caráter informativo ou intelectivo, efeitos igualmente possíveis com o uso do discurso indireto; ao contrário, conservam a realidade concreta do tempo e do lugar a que se vinculam os personagens, bem como características próprias de cada um deles. Tal efeito não seria possível caso o narrador incorporasse ao seu próprio falar determinadas informações sobre o personagem. Seus personagens não estão, portanto, subordinados ao narrador, ao contrário, suas matizes de expressão e de pensamentos são preservadas. Mais do que ser informado sobre o que os personagens teriam dito, o leitor ouve a voz desses personagens, o que dá mais sabor e prazer à leitura. 
II - "Tzar" e "mujique", termos genéricos

Seguramente, para se aproximar da realidade de seus alunos e, provavelmente, também porque os títulos não eram o que mais lhe interessava, Tolstói empregou sempre o termo "tzar", independentemente de o soberano governar a Rússia, a China, a Itália ou qualquer país árabe, ou de religião muçulmana. Na tradução, usou-se "tzar" apenas quando se tratava de um contexto russo; por razões evidentes, nas fábulas, o termo "tzar" foi, na maior parte dos casos, substituído por "rei”, termo também usado quando o contexto não me forneceu indicações geográficas nem culturais precisas. De resto, empreguei também "xá", "faraó" e "imperador", conforme o contexto exigia. Ainda em casos isolados, como ocorreu no conto "Polícrates de Samos" — ou Поликрат Самосский — preferi o título de "governante", por sua maior abrangência.

Acredito que os mesmos motivos levaram Tolstói a empregar de maneira generalizada o termo "mujique". Na tradução, conservei o termo apenas quando se tratava de um camponês russo, procurando, assim, dar mais cor local à leitura. Quando não se tratava de personagem russo, "mujique", na versão em língua portuguesa, foi traduzido por "camponês".

\section{III - Repetição de termos e sinônimos}

Algumas vezes, Tolstói parece não se preocupar em encontrar sinônimos; outras vezes, parece repetir intencionalmente várias vezes o mesmo termo em um único texto. É fato que a repetição em língua portuguesa é, geralmente, incômoda, no entanto, de maneira geral, a língua russa parece ignorá-la, suportando-a sem os nossos desconfortos. Dentre inúmeros exemplos, citarei os seguintes:

Один ияарь на охоте пустил за зайщем любимого сокола и поскакал.

Сокол поймал зайца. Царь отнял зайца и стал искать воды, где бы напиться.

Durante uma caça, um rei soltou o seu falcão preferido atrás de uma lebre, e saiu a galope. O falcão agarrou a lebre. O rei arrancou-lhe a lebre, e começou a procurar água para matar a sede.

Extraído de Царь и сокол, ou "O tzar e o falcão" 
A primeira ocorrência do termo "lebre" foi, obviamente, mantida na tradução. A segunda ocorrência deste mesmo termo poderia, se assim eu o desejasse, ser evitada; para tanto, bastaria trocar o substantivo "lebre" pelo pronome oblíquo "a", ou seja, “O falcão agarrou-a.” Apesar de possível, a substituição não seria indispensável, sobretudo por se tratar de um novo parágrafo, tampouco desejei substituir o substantivo em questão por algum sinônimo genérico, como "animal", por exemplo. Ademais, pareceu-me que a língua de chegada ainda suportaria uma terceira, e última, ocorrência do termo. Assim, pensei ter conservado o ritmo do original, que segue uma sequência lógica, construída por períodos curtos, de pequenas etapas igualmente breves, e que nos lembram alguns jogos infantis, que se utilizam de repetições a cada pequeno passo, para que se chegue ao resultado final.

Em resumo procurei, sempre que possível, conservar a repetição de um mesmo termo, mesmo que o resultado final ficasse um tanto "carregado" em português, e justifico minha escolha: se desejasse,Tolstói teria, em várias passagens, empregado sinônimos, mas ele não o fez; crianças gostam da repetição, e ela é necessária ao aprendizado; finalmente, constatei que, em vários casos, a repetição proporcionou um bom ritmo ao texto de chegada.

IV $-\underline{\text { Ritmo }}$

Em determinados textos, Tolstói é bastante pontual, o que fornece um certo ritmo ao texto:

Повар готовил обед; собаки лежсали у дверей кухни. Повар убил телёнка и бросил кишки на двор. Собаки подхватили, поели и говорят: «Повар хороший: хорошо стряпает».

$\mathrm{Na}$ tradução, procurei conservar tal estrutura, muitas vezes entrecortada, pois suas frases curtas e diretas fazem parte da simplicidade que ele julgava importante, bem como da clareza que, em minha opinião, é importante em textos pedagógicos:

Um cozinheiro preparou o almoço; os cães estavam deitados à porta da cozinha. O cozinheiro matou um bezerro e jogou as tripas no quintal. Os cachorros apanharam-nas, comeram-nas e disseram: 
- O cozinheiro é bom: ele cozinha bem.

Extraído de Собаки и повар, ou "Os cachorros e o cozinheiro"

Uma opção de tradução menos aconselhável talvez fosse:

Enquanto um cozinheiro preparava o almoço, os cachorros ficaram deitados à porta da cozinha. Depois de matar um bezerro, o cozinheiro jogou as tripas do animal no quintal.

ou:

Alguns cachorros estavam deitados à porta da cozinha enquanto um cozinheiro preparava o almoço. Depois de matar um bezerro, o cozinheiro jogou as tripas do animal no quintal.

Para conseguir um ritmo cadenciado, optei por repetir algumas construções quando elas se encontravam em sequência, mesmo que as repetições não ocorressem no original. Justifico tal procedimento pelas várias perdas que, na maioria das vezes, acompanham o texto da língua de chegada, perdas estas que, algumas vezes, podem não ser detectadas nem mesmo pelo tradutor:

Чувства у паука так тонки, что когда в воздухе начнет только собираться сырость,

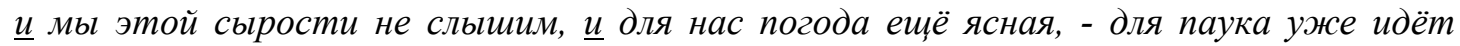
дождb.

Os sentidos da aranha são tão aguçados que, quando a umidade do ar mal começa a se formar, quando sequer conseguimos percebê-la, e quando, para nós o dia ainda está claro, para a aranha o dia já está chuvoso.

Extraído de Cblpocmb I, ou "Umidade I".

ou ainda:

Точно так же, как и человек раздетый сейчас почувствует сырость, а одетый не заметит её, [...]

Do mesmo modo como uma pessoa mal agasalhada sente logo a unidade, e outra pessoa bem agasalhada não a percebe [...]

Extraído de Cырость I, ou "Umidade I".

No exemplo acima, a repetição do mesmo termo - em russo человек ou "pessoa" - compensa a adversativa " $a$ ", ou "mas", do original russo, que, em português, foi traduzida simplesmente pela conjunção “e”. 
No texto "Umidade II", ou "Cbipocmb II», Tolstói realça os nomes de duas

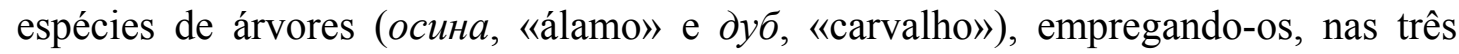
vezes que os cita, entre travessões, sem nenhum elemento que os introduza, ou que os acompanhe:

Отчего слабое дерево - осина - больме разбухает, а дуб меньше?

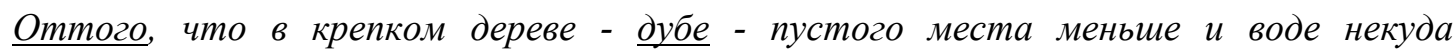
набраться, а в слабом дереве - осине - пустого места больше и воде есть куда набраться.

Por que uma árvore frágil como o álamo dilata-se mais do que o carvalho?

Porque árvores resistentes como o carvalho têm menos espaços ocos, e a água não tem onde se acumular, e porque árvores frágeis como o álamo têm mais espaços ocos, e a água tem onde se acumular.

Nesse trecho, tentei acompanhar a pequena ênfase que detectei no original, servindo-me da expressão "como + o nome da árvore", repetindo-a também três vezes. Além disso, contrariando o original, repeti duas vezes a conjunção causal "porque".

Vejamos também o seguinte exemplo:

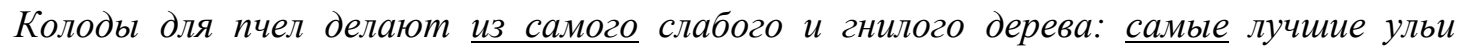
бывают из гнилой лозины.

As colmeias de abelhas são feitas com a mais fraca e com a mais podre das madeiras: as melhores colmeias são feitas com os mais podres salgueiros.

Assim, sendo mais insistente do que o texto original, pensei criar um determinado ritmo que me agrada nesses textos. Outra versão possível seria:

As colmeias de abelhas são feitas com a mais fraca e a mais podre madeira: [...]. 


\section{V- Léxico}

Procurei acompanhar a simplicidade que detectei na estrutura gramatical e sintática de Tolstói. Quanto ao léxico, também simples, saliento que, além de tentar buscar equivalentes em português, entendo que, por si só, a repetição voluntária de determinados termos é, nesse tipo de texto, mais um indício de simplicidade. Quanto à gramática, esforcei-me para mantê-la correta, no entanto, simples, direta e clara na língua de chegada.

No vocabulário empregado pelos camponeses de Tolstói, ocorre, embora raramente, o uso de um ou outro regionalismo - termos e construções usados sobretudo na zona rural russa. De maneira geral, no entanto, não foram detectados casos significativos dessa espécie de "névoa regional" na fala de seus personagens camponeses, cujo estilo se mostrou sempre simples e gramaticalmente correto. $\mathrm{Na}$ tradução, não recorri, portanto, a qualquer tipo de fala marcadamente regional, como a do caipira paulista ou a do mineiro, por exemplo, nem ao emprego de vocábulos próprios de uma ou outra região do país.

No tocante à linguagem nitidamente familiar — ou popular — contida nos textos originais em língua russa, em português, procurei evitar palavras e expressões populares consideradas "grosseiras", e busquei equivalentes comumente empregados na linguagem familiar, ou popular, da língua de chegada. A título de exemplo, em " $\mathrm{O}$ cachorro e o lobo", ou Собака и волк, temos a seguinte expressão:

\section{[...] тогда мне еды будет вволю, [...] \\ e, em minha tradução: \\ [...] então, vou me empanturrar de comida, [...]}

A seguir, temos algumas observações pontuais, principalmente sobre o léxico:

1) Convencionei traduzir русак por «lebre das estepes», já que se trata de uma lebre grande e avermelhada, diferente das lebres ordinárias, e comum nas estepes russas. Já заяи foi traduzido simplesmente por «lebre». 
2) Em relação a termos bíblicos, procurei, sempre que os detectei, ou que assim me pareceram, encontrar equivalentes também bíblicos em português:

- o título Праведный судья, por exemplo, foi traduzido como «O juiz justo», em vez de «O juiz correto», ou «O juiz honesto», dentre outras possibilidades.

- no texto intitulado Слепой и молоко, traduzi o termo зрячий que, de fato, significa «que ou quem vê» por «vidente».

- no conto Царские братья, ou «Os irmãos do rei», o próprio enredo levou-me a escolher «repartir», dentre os sinônimos oferecidos pelo dicionário para traduzir o verbo делиться.

3) Para o termo хозяйка, ou seja, «dona, senhora, patroa, anfitriã, etc.», preferi, em geral, «patroa», principalmente quando um animal assim se referia à sua dona, ou aos donos.

4) Muitas vezes, tentei compensar determinadas perdas ocorridas na tradução, sobretudo as semânticas: no texto «Umidade I», ou Cbıpocmb I, temos a expressão de uso popular:

Если он выходит из гнезда и делает новые паутины, то это к погоде.

Na tradução, em vez de, por exemplo,

[...] significa que o tempo será bom”, ou "que fará bom tempo".

optei por:

Se ela sair do ninho e fizer uma nova teia, quer dizer que o tempo vai ser bom.

5) Traduzi куnеи por «mercador», е торговеи por «comerciante».

6) Traduzi манеж por «picadeiro», por considerar esse termo mais conveniente do que «hípica».

7) Traduzi сени por «varanda», pois, segundo o dicionário Aurélio, trata-se de um cômodo de frente das casas rústicas. Assim, evitei opções que, nesse tipo de texto e, em se tratando de uma pobre e simples isbá, seriam verdadeiros erros, como 
«saguão», «hall» e, a rigor, também «vestíbulo». «Entrada» pareceu-me demasiadamente vago para um cômodo importante das casas dos camponeses russos.

8) Sempre que possível, mantive a ideia de reforço e de ênfase produzida por determinados termos, ou partículas, como жe, $u$, etc. Na fábula «O filhote de gralha», ои Галчонок:

[...] и научил же Бог этого сокола [...]

[...] e Deus bem que ensinou este falcão [...].

ou, ainda:

Вот мужик й говорит:

Eis que o camponês, então, disse:

em vez de, simplesmente,

O camponês disse:

9) Mais do que Tolstói, a própria língua russa falada no cotidiano parece entender e empregar o termo комната, ou «quarto», em sua primeira acepção, de maneira genérica. Conservei «quarto» apenas em casos em que realmente se tratava de um «dormitório». De resto, segui a lógica indicada pelo contexto; quando ele não me permitia definir com clareza o tipo de aposento, optei, em geral, pelo termo «cômodo». Vejamos um exemplo que considero extremo: no texto «Como aprendi a cavalgar», ou Как я выучился ездить верхом, este mesmo termo é empregado para indicar um lugar fechado, cheio de areia no chão, e por onde cavalgam várias pessoas. Tolstói dá a esse lugar, no início, um nome genérico, комната, descreve-o rapidamente e, em seguida, diz tratar-se de um «picadeiro» ou манеж. Preferi uma indicação mais exata, e empreguei o termo «galpão», pois me pareceu uma opção razoável, já que o uso de «cômodo», neste caso, seria descabido em português.

10) Alguns exemplos da preferência por um vocabulário mais simples também na língua de chegada: 
- no texto «O fim de Bulka e Milton», оu Конец Бульки и Мильтона, optei pelos termos «raiva», «raivoso», etc., a «hidrofobia», «hidrófobo», etc. Neste mesmo texto, preferi «cãibras» a «espasmos» ou «convulsões».

- em «O juiz justo», оu Праведныцй судья, aо me referir a um julgamento conduzido por um juiz, para traduzir o verbo cnросumb preferi «perguntar» a «interrogar», «indagar», etc., dentre outras várias possibilidades.

11) Transcrevi, em português, o termo xama, com explicação em nota de rodapé, porque ele ainda não está dicionarizado em português mas, assim como a «isbá», é um tipo específico de habitação, desconhecido do leitor brasileiro, de maneira geral.

12) Não recorri ao mesmo procedimento em relação ao termo станиц̧а, e preferi traduzi-lo por «aldeia cossaca», no corpo do texto.

13) Двор foi traduzido por «pátio» ou por «quintal», segundo o contexto.

14) Para manter um pouco o «tom» da época em que os textos foram escritos, preferi conservar as várias unidades de medidas, como archin, pound, pud, versta, etc., a convertê-las em quilos, metros, etc. Servi-me, nesses casos, de notas de rodapé.

15) Em enumerações, é comum na língua russa o uso repetido da conjunção $u$, ou «e». Por exemplo, na seguinte frase:

А иаревич говорит: "Купиу деньги нужны, мне изарство нужно, тебе сила

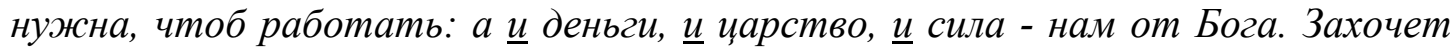

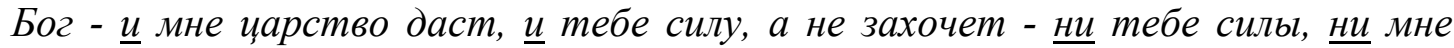
ичарства не даст»

que, em português, resultou:

E o príncipe disse:

-O mercador precisa de dinheiro, eu preciso de um reino, e você precisa de força para trabalhar. Dinheiro, reino e força: tudo isso vem de Deus. Se for a Sua vontade, a mim, Ele 
dará um reino e, a você, Ele dará força. Mas, se não for a Sua vontade, Ele não lhe dará força e nem me dará um reino.

Não são freqüentes os casos em que a língua portuguesa oferece a mesma possibilidade em situações de enumerações; em geral, a conjunção antecede apenas o último termo da sequência. Para preservar o "efeito acumulativo" do original, alterei a sintaxe: iniciei a frase com os três termos que, em russo, são enfatizados pela conjunção, separei-os apenas com vírgulas, criando, dessa maneira, uma seqüência mais dinâmica; dispensei o uso de artigo e acrescentei dois pontos após o terceiro termo; retomei os três termos com a expressão "tudo isso".

Em seguida, temos no original a dupla ocorrência dessa mesma conjunção:

\section{[...] Захочет Бог - ймне иарство даст, й тебе силу [...]}

Procurei recuperá-las da seguinte maneira:

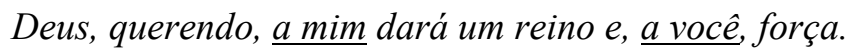

Ou seja, acredito ter enfatizado "a mim" e "a você", colocando ambas as expressões entre vírgulas, e repetindo o verbo "dar".

Por último, a dupla ocorrência da partícula $н u$ foi traduzida por «não... nem». Acredito ser essa a forma mais desejável em português.

16) No texto «O filho do rei e seus companheiros», ou «Царский сын и его mоварищии», a dificuldade de traduzir o termo meneps foi resolvida da seguinte forma, em duas ocorrências:

На пути сошелся он с купиом. Купец рассказавал иаревичу, что был он прежде богат, но что все его товары потонули в море и что он идёт теперь в чужие края поискать счастья.

No caminho, ele encontrou um mercador. O mercador contou-lhe que, antes, ele fora rico, mas que toda a sua mercadoria havia afundado no mar, e que, então, ele estava indo procurar a felicidade em outras terras. 
Они пошли вместе. На третий день сошелся с ними ещеё товарищ. Они разговарились, и новый товарищ рассказал, что он мужик; были у него дом и земля, но что была война, поля его стоптали и двор его сожгли, - не при чем ему стало жить, - и что идёт он теперь искать работы на чужую сторону.

Ambos seguiram juntos. No terceiro dia, a eles juntou-se um companheiro. Conversa vai, conversa vem, e o novo companheiro contou-lhes que era camponês, que tivera casa e terra mas que, com a guerra, seus campos haviam sido destruidos e, o seu quintal, queimado. Diante disso, nada lhe sobrara para viver e, então, ele estava indo procurar trabalho em outras terras.

Para manter a noção de tempo concentrada em um único termo, menepb, optei pelo advérbio "então", equivalente a "nesse ou naquele tempo, nesse ou naquele momento, ou ocasião", visto que, embora se refira a um tempo presente da narrativa, o que temos é a voz do narrador, ou seja, uma terceira pessoa está contando um fato já ocorrido. Tenepb, ou «agora», foi também traduzido pela fórmula verbal «estar+ir+verbo principal», o que me pareceu adequado para sugerir a ideia de que o fato ocorre naquele momento, no momento a que se refere o narrador. A escolha dos tempos verbais e dos advérbios no conjunto desse período traduz, ou vai aos poucos traduzindo, o advérbio meneps do original: temos, em português, o advérbio «antes», em seguida, o pretérito mais-que-perfeito simples «fora» que, por sua vez, é seguido de «havia afundado», ou seja, pretérito mais-que-perfeito composto. Ao período, tanto o advérbio «antes» como a conjunção «e», seguida da conjunção subordinativa integrante «que», concedem igualmente uma espécie de pausa, também presente no original:

\section{[...] и чтто он идёт теперь в [...]}

e, finalmente, graças ao emprego da construção «estava indo procurar» concretiza-se, completa-se e integra-se ao contexto, a ideia de tempo expressa pelo advérbio menepb. O próprio contexto acompanha muito bem esse andamento. Segui praticamente o mesmo raciocínio para traduzir o segundo trecho, acima transcrito.

$\mathrm{Na}$ terceira ocorrência deste mesmo advérbio russo, não vi razão para não empregá-lo em uma tradução direta; achei por bem mudar apenas a sua posição na 
frase. Tal procedimento seria dispensável, mas tornou a leitura mais fluente na língua de chegada:

Они пошли все вместе. Подошли они к большому городу и сели отдохнуть, Вот мужик и говорит: «Ну, братиы, будет нам гулять, теперь мы пришли к городу, надо нам за работу приниматься, кто какую умеет».

Eles seguiram todos juntos. Chegaram a uma grande cidade e sentaram-se para descansar. Eis que o camponês, então, disse

- Bem, meus irmãos, basta de tanto vadiar. Agora que chegamos a uma cidade, precisamos começar a procurar trabalho, cada qual em seu oficio.

Gostaria de ressaltar que a seguinte versão estaria igualmente correta:

Eles seguiram todos juntos. Chegaram a uma grande cidade e sentaram-se para descansar. Eis que o camponês, então, disse:

- Bem, meus irmãos, basta de tanto andar. Chegamos a uma cidade, agora precisamos começar a procurar trabalho, cada qual em seu oficio.

17) Algumas vezes, Tolstói emprega determinados termos e expressões bastante engenhosos e adequados ao mundo infantil; sempre que detectados, foram mantidos em minha tradução.

- No conto «O que aconteceu com Bulka em Piatigorsk", ou Что случилось с Булькой в Пятигорске, por exemplo, Tolstói emprega o termo голова para se referir ao «topo», ao «cume» de uma montanha; conservei «cabeça» na versão em língua portuguesa. Especialmente neste caso, о termо голова produz um contraste interessante com os demais termos que se seguem, como «caramanchões», «alpendres», «veredas», etc., todos eles empregados na descrição do vilarejo montanhoso, e pertencentes, se não a uma linguagem mais culta, ao menos à linguagem comum, mas não forçosamente à infantil. Pedagogicamente falando, tal procedimento parece-me ser uma estratégia boa para que o contador da história possa se aproximar da criança e, assim, despertar e/ou manter o seu interesse pela sequência da história, em que, necessariamente, encontram-se vocábulos novos que, ao menos em teoria, a criança desconhece. Dessa maneira, a curiosidade intelectual dela é «fisgada», ou despertada, e cultivada; 
- No texto intitulado «A tartaruga», ou Yepenaxa, Tolstói serve-se de um procedimento semelhante: ao descrever o interior do casco do animal, utiliza termos como «buracos na frente, atrás e do lado», ou «porão», ou, ainda, para se referir ao corpo da tartaruga, «coisa preta e viva». Suponho que os alunos de Iásnaia Poliana não conheciam, de fato, nenhuma tartaruga; apesar disso, conservei, na tradução, tais termos e expressões porque, em primeiro lugar, não vi motivos para agir de outra maneira e, em segundo lugar, porque julguei que tais escolhas fazem parte do estilo e do desejo do autor, além de enriquecer o texto literário. Vejamos os exemplos em seus contextos:

Когда держишь ее в руках и смотришь под скорлупу, то только внутри, как в подвале, видно что-то черное и живое.

Quando seguramos uma tartaruga nas mãos e olhamos dentro do casco, bem lá dentro, como se fosse num porão, vemos uma coisa preta e viva.

Ou, ainda:

Только спереди, сзади и с боков есть отверстия, куда она пропускает голову, ноги и xвост.

Elas têm apenas buracos na frente, atrás e do lado, por onde saem a cabeça, as patas e o rabo.

Para descrever o animal, Tolstói escolhe fazer comparações com lugares, objetos, etc., conhecidos por seus alunos, e é sobretudo nesses momentos que a qualidade literária do texto parece se tornar mais intensa. Que suspense não nortearia a imaginação de uma criança que nunca viu uma tartaruga ao se relacionar o corpo do animal a um porão escuro, visto de fora, mas onde se vê "uma coisa preta e viva"? - em «Os cachorros e o cozinheiro», ou Собаки и повар, os cachorros empregam uma divertida expressão para qualificar o cozinheiro, a saber:

Испортился наш повар - прежде хорошо готовил а теперь никуда не годится

ou seja: 
Nosso cozinheiro ficou estragado: antes cozinhava bem, mas agora não presta para nada

A escolha do autor foi a minha escolha.

- No texto “O gelo, a água e o vapor”, ou Лёд, вода и nap, Tolstói usa dois adjetivos que, ao caracterizarem o substantivo, formam expressões bastante divertidas: летучая вода е крепкая вода, ou «água voadora» e «água dura». Com prazer, conservei esses mesmos termos em minha versão.

18) O verbo nemyшиться, presente no texto "Os faisões", ou Фазаны, significa «brigar como galo»; na tradução, preferi desprezar o verbo e optei pela expressão «parece um galo de rinha». Seguem ambos os fragmentos:

Когда собака одна лает на фазана, он не боится её, сидит на сучке и ещё петушится на неё и хлопает крыльями.

Quando um cão late para um faisão, a ave não sente medo dele, fica no galho e bate as asas, parecendo um galo de rinha.

19) Identifiquei a seguinte característica em alguns dos textos que compõem o Terceiro Livro de Leitura, a saber, Tolstói emprega, muitas vezes, termos despidos de qualquer atenuante, ou bastante diretos, em contextos igualmente duros. Em todos os casos, procurei ser fiel, buscando, em português, termos equivalentes, embora eles possam soar estranhos ou, via de regra, «rudes» ao leitor comum. Darei, a seguir, alguns exemplos. Vejamos, em primeiro lugar, um fragmento extraído de «O que aconteceu com Bulka em Piatigorsk", ou Что случилось с Булькой в Пятигорске:

Перед нашими воротами один колодник крючком зачепил дворную собачонку, притянул её на середину улиць, а другой колодник стал бить её дубиной. Собачонка визжала ужасно, а колодники кричали что-то и смеялись. Колодник с крючком перевернул собачонку, и когда увидал, что она издохла, он вынул крючок и стал оглядываться, нет ли ещё собаки.

Na frente do portão, um condenado pegou um vira-lata com o gancho e puxou-o até o meio da rua, e outro condenado começou a bater nele. O cachorrinho gritava terrivelmente, e os 
condenados gritavam sabe-se lá o quê e riam. Um condenado virou o cachorrinho com o gancho e, quando viu que ele já estava morto, retirou o gancho e começou a olhar se não havia mais um cachorro ainda.

$\mathrm{Ou}$, ainda, em «A codorna e seus filhotes», ou Перепёлка и перепелята:

Ребята принесли мужикам на покос обедать; услыхали перепелят и порвали им головы.

Crianças levaram almoço aos camponeses que ceifavam, ouviram os filhotes e torceram-lhe os pescoços.

20) Em determinados casos, voluntariamente empreguei sinônimos não marcadamente presentes no contexto que se traduzia, mas igualmente, e de maneira geral, pouco comuns ao assunto em questão. Assim, além de esperar recuperar perdas esparsas pelos textos, acredito não ter desrespeitado o estilo dessa literatura de Tolstói. Em outras palavras, em certas passagens, busquei criar uma espécie de estranhamento; para tanto, desloquei determinado termo do contexto em que ele é usualmente empregado e o agreguei a outro contexto. No exemplo que se segue, o mais comum seria optar pelo verbo «farejar», visto tratar-se do olfato de um animal; preferi, no entanto, o verbo «cheirar» que, embora sinônimo de «farejar», é comumente empregado quando se trata de seres humanos. Outras opções seriam igualmente válidas para uma correta interpretação, tais como «perceber (ou distinguir) o cheiro de sangue», «sentir o odor de sangue», dentre outras que tampouco me agradaram.

No texto «O olfato», ou Чymbё:

Быки видят, как бъют быков, слышат, как ревут быки на бойне, и всё не понимают, что такое делается. Но стоит корове или быку найти на место, где бычачья кровь, да понюхать, и он поймет, начиет реветь, бить ногами, и его не отгонишь от того места.

Os bois vêem outros bois sendo abatidos, ouvem seus mugidos no abatedouro e não entendem nada do que está acontecendo. Mas, se uma vaca ou um boi for ao lugar onde há sangue de 
outros bois, ao cheirar, ele logo entenderá, começará a mugir, a bater os cascos, e ninguém conseguirá enxotá-lo daquele lugar.

Mostro, a seguir, mais um exemplo que, apenas por coincidência, mantem relações de significado com o sentido do olfato:

«Ребята! этот человек подослан к нам от наших злодеев разузнавать про наш город.»

- Pessoal! Este homem foi enviado até nós pelos assassinos para fariscar a nossa cidade.

O verbo разузнавать pode ser traduzido por «informar-se», «indagar», etc. Preferi, não obstante, o verbo «fariscar», de «faro» e «iscar», o que, acredito, proporcionou um ganho ao texto em língua portuguesa. Gostaria de esclarecer que tais opções estão estritamente relacionadas ao meu gosto pessoal, que se faz presente também na tradução. Elas não são, portanto, limitativas.

21) No texto «Vida de um soldado», ou Солдаткино житье, temos o termo хлебушк, ou «рãozinho». Trata-se de um diminutivo afetuoso, bastante comum em russo, sobretudo na linguagem das pessoas mais simples. Em português, embora o diminutivo também possa denotar afetividade, e esteja bastante presente, sobretudo na fala infantil, ele ainda me parece diferente quando ocorre em russo. A opção pelo diminutivo na língua russa, sobretudo quando empregado em termos que designam alimentos, parece-me cristalizada na história e na cultura do povo, em sua maneira própria, e talvez até inconsciente, de se relacionar com o que a terra produz, e que, mais tarde, é transformado em alimento. Optei, para conservar esse caráter afetivo, não por «pãozinho», mas por «um pedacinho de pão», pois «pãozinho», em português, significa «pão pequeno»e, embora o menino-protagonista pudesse se enganar em sua fala, trocando «um pequeno pedaço de pão» por «um pãozinho», julguei que «um pedacinho de pão» realçaria a humildade com que Fedka, um menino pobre, desejou um pedaço do pão russo, em geral de tamanho grande, iguaria que estava sobre a mesa posta para a festa de casamento de sua irmã.

22) Mesóclise: apesar de toda e qualquer simplicidade que deva constar das traduções dos textos dos Livros de Leitura de Tolstói, não abri mão da mesóclise sempre que ela 
se fez necessária, ou seja, com o futuro do presente e com o futuro do pretérito, principalmente quando ela ocorria no rosto, ou início, da oração. Procurei, obviamente, respeitar também os casos de próclise e ênclise.

23) Dentre outras, o texto «Os faisões», ou Фазаньl, apresentou-me uma grande dificuldade; nele, Tolstói fala sobre três tipos, ou modalidades, de caça comuns na caça ao faisão; segundo ele, essas aves são caçadas $c$ кобльлккой, с подсаду, е из-под собаки. Os dicionários traduzem кобылка por «jumento», «cavalete», «pontal (de serrador)». «Pontal» oferece significados bastante amplos, como, de acordo com o Dicionário Aurélio, "1) Altura de embarcação entre a quilha e o convés principal; 2) Ponta de terra ou penedia que penetra um pouco no mar ou no rio; 3) Pontalete de madeira serrada longitudinalmente."

Em um primeiro momento, «pontalete» - espécie de barrote de madeira usado sobretudo na construção, como apoio de casas ou pavimentos; escora de madeira; forquilha em que se descansa o braço do andor nas procissões — pareceume razoável, mas a descrição do próprio Tolstói levou-me a desistir de «pontalete», pois a base dessa engenhoca de caça é uma espécie de moldura, e uma moldura não é um barrote. Optei, então, por «caixilho», que, embora também seja sinônimo de «moldura», nele pode-se pregar uma lona e pode-se colocar uma barra no centro, conforme o texto descreve.

Encontrei outro problema; depois de ensinar a montar tal instrumento de caça, Tolstói diz:

Эта рамка с парусиной называется кобылкой.

«Essa moldura e a lona chamam-se... (caixilho?)». Não, pois um caixilho não precisa de uma lona para ser um caixilho. Se prendermos uma lona nele, continuará a ser um caixilho, apenas um caixilho com uma lona presa. Restou-me uma última solução: alterar levemente a frase para: «Chamam a essa moldura e lona de caixilho». Tal solução não me satisfez completamente, mas foi o melhor que consegui criar. Tenho consciência de que o correto seria achar a tradução exata do termo.

Sobre a segunda modalidade, $c$ nodcady, encontrei as seguintes informações em dicionários: nodcad — plantação formada por plantas jovens que crescem em um monte, e são de diferentes espécies. Aqui também me fez falta a tradução exata e 
técnica dessa modalidade de caça. Deixei-me guiar pelo texto, e percebi que um cão comum, sem raça, um дворовая собака, participa ativamente de tal caça. Decidi, então, traduzir $c$ noдcady por «caça com vira-lata».

Quanto à última modalidade, из-под собаки, segui o mesmo processo anterior, ou seja, o próprio texto me indicou uma solução; aqui, o cão da raça perdigueiro é o protagonista da caça aos faisões. Optei por traduzir из-под собаки por «caça com perdigueiro».

Assim ficou o início dos três parágrafos que introduzem a descrição de cada tipo de modalidade de caça:

С кобылкой вот как охотятся:

Eis como se caça com um caixilho:

C подсаду охотятся вот как:

Eis como se caça com um vira-lata:

Из-под собаки охотятся вот как:

Eis como se caça com um perdigueiro:

24) Sempre que necessário, evitei traduzir o verbo xomemb, bastante frequente em locuções verbais em russo, mas pouco natural em português quando traduzido em excesso. No exemplo a seguir, extraído do texto «Vida de um soldado», ou Солдаткино житье, o verbo auxiliar хотеть poderia ser traduzido por «querer», mas não necessariamente. No texto temos:

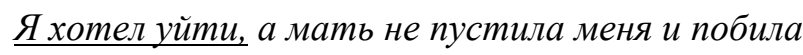

Mesmo assim, tentei ir, mas mamãe não deixou e deu-me um tapa.

No seguinte exemplo, extraído de «O rei e o falcão», ou Царь и сокол, pareceu-me desaconselhável a tradução literal desse mesmo verbo auxiliar russo:

Вода текла по капле, и когда чаша набралась полная, иарь поднял её ко рту и хотел numb. 
A água apenas gotejava e, quando a caneca ficou cheia, o rei levou-a à boca para beber. ou

“[...] ia levá-la à boca para tentar bebê-la.", visto que o falcão derrubá-la-ia uma vez mais.

É evidente que o personagem queria beber a água. A questão está na insistente ocorrência desse mesmo auxiliar ao lado de inúmeros outros verbos principais; se o tradutor não atentar para essa característica da língua russa, terá, fatalmente, um texto em português bastante viciado, carregado e pouco natural na língua de chegada.

No exemplo abaixo, extraído do texto «Polícrates de Samos», Поликрат Самосский, vejo, pelo menos, três possibilidades de tradução da locução «querer + verbo principal»:

На пятый день одному рыбаку случилось поймать очень больщую, прекрасную рыбу, и захотел он подарить её иарю.

Cinco dias depois, um pescador teve a ocasião de apanhar um peixe muito grande e bonito, e quis dá-lo ao governante.

ou

Cinco dias depois, um pescador teve a ocasião de apanhar um peixe muito grande e bonito, $e$ teve a ideia de dá-lo ao governante.

ou

Cinco dias depois, um pescador teve a ocasião de apanhar um peixe muito grande e bonito, $e$ resolveu dá-lo ao governante.

25) Adotei, de maneira geral, o mesmo procedimento em realção à locução, também muito frequente em russo, composta pelo verbo «começar (cmamb) + verbo principal» que, se traduzida de modo insistente, comprometeria o texto final na língua de chegada. A seguir, um exemplo extraído do texto «O filho do rei e seus companheiros», Царский сын и его товарищи:

Входит изаревич в город, видит он - народ ходит по улицам и плачет. Царевич стал спрашивать, о чем плачут.

O jovem príncipe foi para a cidade. Lá, ele viu pessoas andando aos prantos pelas ruas. $O$ jovem príncipe começou a perguntar por que elas choravam. 
Caso houvesse acúmulo no texto de tal locução, e caso o seu significado (ou importância) semântico não fosse demasiadamente relevante, outra versão possível seria:

O jovem príncipe foi para a cidade. Lá, ele viu gente andando aos prantos pelas ruas. $O$ jovem príncipe foi perguntando a um e outro por que choravam.

Quer seja, o não emprego da locução e, em seu lugar, apenas o emprego do verbo principal, conjugado no mesmo tempo verbal em que está conjugado o verbo auxiliar no texto original.

Dou, a seguir, um exemplo mais: No texto «Deus diz a verdade, mas não a diz logo», Бог правду видит, да не скоро скажет, essa mesma locução poderia, ou não, ser traduzida literalmente:

Раз летом Аксенов поехал в Нижний на ярмарку. Когда он стал прощаться с семьей, жена сказала ему: [...]

Certo verão, Aksiónov foi para uma feira, na cidade de Nijni. Durante as despedidas (quando começou a se despedir) da família, sua mulher pediu-lhe: [...]

Um último exemplo, retirado de «Fundação de Roma», Основание Рима:

Нумитор взял иарство, а Амулий взял богатства. Когда Амулий взял богатства, ему стало завидно, что брат его ияарем, и он стал дарить солдат и уговаривать, чтобы они прогнали Нумитора, а его бы поставили царем.

Numitor ficou com o reino e Amulius ficou com a fortuna. Depois de ter ficado com a fortuna, Amulius passou a sentir inveja porque seu irmão era rei, e começou a mimosear os soldados, a convencê-los a expulsar Numitor e a coroá-lo, ele, Amulius, imperador.

Com isso, meu intuito é o de observar que nem sempre se deve traduzir o verbo russo cmamb por «começar a», ou seja, traduzir a locução verbal tal qual. Lembro que existem sinônimos, como «por-se a» «passar a», dentre outros, além de, conforme já comentei acima, ser possível, em vários casos, o emprego apenas do verbo principal. 
26) No texto «Vida de um soldado», Солдаткино житье, preferi traduzir вино por «aguardente», por me parecer esta uma bebida mais comum em festas camponesas.

27) Traduzi a raça do cão Bulka por «mastiff», em russo мордашка. Essa foi outra grande dificuldade que enfrentei em meu trabalho. Tatiana Belinky traduziu as histórias de Bulka e de Milton, outro cão de Tolstói, e conservou o termo «mordachka», explicando-o em uma nota: “A raça mordachka, espécie de mastim russo, é hoje extinta. Seu último sobrevivente pertenceu ao canil do czar, destruído na Revolução de 1917." ${ }^{148}$ Não tenho bases para concordar ou discordar de Tatiana Belinky, mas em minha pesquisa cheguei à conclusão de que Bulka pertencia à raça de cães mastiff, ou a qualquer outra raça semelhante.

28) É comum encontrarmos amiúde, nos textos dos Livros de Leitura, a palavra вeщ̧b, «coisa». Em praticamente todos os casos em que me depararei com ela, esforcei-me para traduzi-la, sempre que possível, exatamente por «coisa», por razões simples: Tolstói empregou o termo porque assim o desejou; trata-se de um termo com vasta gama de significados na língua portuguesa; trata-se, igualmente, de um termo bastante usado em liguagem infantil — mas não apenas — quando não se sabe qual nome dar ao objeto, ou coisa, de que se fala; finalmente, segundo o Dicionário Aurélio, «coisa» significa «aquilo que existe ou que pode existir». No texto «O olfato», Yymbe, por exemplo, a palavra é recorrente.

39) Se, nos contos sobre caça, Tolstói utiliza termos técnicos, parece evitá-los em outros textos, sobretudo em seus «raciocínios»; tentei, em minha tradução, respeitar as suas escolhas.

\section{VI- Organização visual e temática}

Textos como «Por que as árvores estalam no frio?», ou Отчего в морозы трещат деревья?; «Umidade II», ou Cырость II; e «Diferente ligação entre partículas», ou Разная связь частии — todos classificados como «raciocínio», ou рассуждение - são, no original russo, construídos em um grande bloco, separados

${ }^{148}$ TOLSTÓI, L. Histórias de Bulka. (Trad. Tatiana Belinky). São Paulo: Editora 34, 2007. p. 7. 
apenas por parágrafos novos, mesmo quando, embora sobre o mesmo tema, são apresentados novos exemplos ao leitor. Optei, em minha tradução, por separar visualmente a entrada dos novos exemplos que compõem o mesmo raciocínio.

No texto «Por que as árvores estalam no frio?» vi a possibilidade de três pequenos blocos: o primeiro deles corresponde à pergunta do título, e fala-nos sobre a umidade contida nas árvores; o segundo compara o comportamento da água e do ferro sob o efeito do frio; o terceiro explica-nos a não-contração da água quando congelada.

Em seguida, Tolstói trata de um mesmo tema em dois textos distintos: «Umidade I», Cырость I, e «Umidade II», Cырость II. No primeiro, mantive a mesma estrutura do original, ou seja, um texto com cinco parágrafos. O segundo foi, em minha versão, separado em quatro partes: a primeira fala sobre a dilatação da madeira no decorrer das estações do ano; a segunda, sobre os diferentes graus de dilatação em árvores cuja madeira é mais resistente, e em árvores que, ao contrário, têm madeira mais frágil; na terceira parte, ficamos conhecendo a madeira ideal para a construção de colmeias; e, finalmente, o texto do quarto e último bloco explica ao leitor o que leva a maderia a empenar-se.

Embora bastante breve, o último texto, «Diferente ligação entre partículas», Разная связь частии, foi, na tradução, dividido em duas partes: na primeira, Tolstói descreve os tipos de madeiras empregadas na construção das telegas; na segunda, ele menciona os fatores que levam à escolha de determinada qualidade de madeira, e não de outra, para a fabricação das rodas dos patins dos trenós.

A mesma disposição encontrada no original, foi conservada na tradução dos dois outros «raciocínios», a saber, «O olfato», Yymbe, e «O gelo, a água, e o vapor», Лед, вода и пар.

VII- Notas de rodapé

Procurei evitá-las sempre que possível. Recorri, no entanto, a elas, quando quis oferecer ao leitor informações adicionais, ilustrativas, sobre o texto, embora não necessariamente imprescindíveis para a compreensão dele. Como exemplo, citarei a de número 106, que acompanha o texto «A lebre e o galgo», Заяи и гончая собака, e a de número 107, que acompanha o texto «As lebres», 3aŭusb: 
Cão lebréu. Uma das raças de cães que Tolstói usava para caçar. O galgo é bastante utilizado para caçar lebres, principalmente. É um ótimo cão de companhia e apega-se muito ao dono. É um animal tímido e dócil. (N.T.)

Na Rússia, os cereais são semeados no outono, passam o inverno sob a neve, brotam na primavera e são colhidos no verão. (N.T.)

Algumas notas pareceram-me mais necessárias, como, por exemplo, a de número 109, do texto «Por que as árvores estalam no frio?», Отчего в морозы mрещат деревья?, ou a de número 111, do texto «Diferente ligação entre partículas», Разная связь частии, dentre outras:

Na Rússia, durante o inverno, os canhões devem permanecer com a boca virada para baixo justamente para evitar que a água da chuva entre neles, acumule-se e congele-se. (N.T.)

A madeira do carvalho é mais resistente do que a madeira da bétula. (N.T.)

Não fugi às notas básicas, presentes na maioria das traduções do russo para o português, como esclarecimentos sobre o significado de piétchka, sobre diminutivos de nomes masculinos — que, em português, são nomes femininos —, sobre o significado de versta, bem como de outras medidas usadas por Tolstói, etc.

Conservei, obviamente, todas as notas do autor, como a de número 113, do texto «Como aprendi a cavalgar», Как я выучился ездить верхом», e a de número 142, do texto «O fim de Bulka e Milton», Конец Бульки и Мильтона:

Corda usada para fazer o cavalo andar em círculos. (N.A.)

Javali de dois anos, e com afiados e sobressalentes dentes caninos. (N.A.)

O texto que mais notas exigiu — dezoito ao todo — foi «Vida de um soldado», Солдаткино житье. O texto relata a vida de uma família de camponeses russos, tratando exclusivamente de costumes próprios ao campo, de tradições ligadas a cerimônias de nascimento, batismo, casamento, morte. Apesar de numerosas, as notas foram, na medida do possível, redigidas de maneira clara, breve e objetiva; ao meu ver, enriquecerão a leitura desse belo conto. 
No conto «O que aconteceu a Bulka em Piatigorsk», Что случилось $c$ Булькой в Пятигорске, fui obrigada, pelo próprio Tolstói, a acrescentar duas pequenas notas, com a tradução do nome de um vilarejo montanhoso, porque Tolstói usa palavras em tártaro para explicar o nome desse lugarejo, o que me levou a fazer praticamente o mesmo no português, em duas notas:

Em russo, "piat" significa "cinco". (N.T.)

Em russo, "gorá" significa "montanha". (N.T.)

\section{Observações finais:}

1) Vários obstáculos ergueram-se durante o processo tradutório, sobretudo aqueles oriundos da distância que separa a cultura russa da cultura brasileira. Recusei-me, apesar disso, a acrescentar ao corpo do texto traduzido qualquer tipo de explicação, ou comentário, que esclarecesse termos ou passagens mais problemáticos. Acredito que tal opção facilitaria demasiadamente o trabalho do tradutor, o que nem sempre é conveniente para que se obtenha um bom texto na língua de chegada; acredito também que, adulterado, o texto original sofreria alterações injustas, nas duas principais acepções da palavra.

Como para qualquer tradutor, também o meu desejo foi o de que o texto na língua de chegada tivesse o resultado mais próximo possível do texto de partida, tal como Tolstói o escreveu, e com todo e qualquer possível estranhamento que o texto em língua portuguesa pudesse vir a causar ao leitor, sobretudo àqueles que já conhecem os grandes clássicos do escritor.

2) Alguns leitores comuns deram-me seu parecer sobre os textos em português dos Livros de Leitura: a maioria observou que a leitura seguiu de maneira «relativamente normal», mas que, algumas vezes, sentiam-se «solavancos» durante o processo; outros reclamaram da «secura», da «maneira esquisita» de contar histórias; outros, ainda, aconselharam-me a mudar o estilo. Aqueles que já haviam tido a oportunidade de ler outras obras de Tolstói, sobretudo Anna Karênina, disseram que, embora escritos para crianças, os textos do Livros de Leitura não pareciam ter sido escritos pelo mesmo autor. Por fim, uma tradutora estrangeira, mas com bons conhecimentos do português, leu alguns textos e fez a seguinte observação: «Não gostei. Se eu fosse traduzir, faria tudo diferente, mais bonito, mais agradável de se ler». Conclui, então, 
que havia conseguido, na tradução, resgatar ao menos um pouco do estilo empregado por Tolstói em seus escritos para crianças.

3) Os textos dos Livros de Leitura estão sendo usados em uma escola pública de São Paulo, no curso de língua portuguesa. A professora, Iris A. de Benedictis, relatou-me que os alunos, de classe média baixa, na faixa etária de 11 a 14 anos, entusiasmaramse bastante com as histórias de modo geral; levaram para a escola material diverso colhido na biblioteca da própria escola, na internet, etc. — relacionado com textos já lidos em sala de aula; compararam elementos, situações, e até objetos da cultura russa com a cultura brasileira; sentiam-se sempre dispostos a debater, em sala de aula, com os colegas e com a professora, diversos assuntos tratados nos Livros de Leitura.

Interessante foi também tomar conhecimento de que «O mar», pertencente ao Primeiro Livro de Leitura, texto em que Tolstói apresenta de maneira sucinta e bela o mar, sobretudo àqueles que não o conhecem, não despertou nenhuma reação positiva entre os alunos que, infelizmente, não se deixaram sensibilizar pela poesia, pelo carinho e pelo respeito com que Tolstói descreve o mar, sempre tão belo, mas já tão conhecido por aqui. Por outro lado, o texto «Os esquimós», também do Primeiro Livro de Leitura, em que Tolstói descreve esse povo, seus hábitos, sua moradia, seus alimentos, suas roupas, etc., provocou, ainda segundo a professora Iris de Benedictis, um verdadeiro e grande interesse nos alunos, que, por vontade própria, buscaram, durante semanas, mais literatura, fotografias e ilustrações sobre o assunto. Essas duas informações causaram-me grande satisfação. Qual seria a reação de um aluno de Iásnaia Poliana ao ler um conto em que Tolstói descrevesse como é uma isbá, como são as roupas usadas pelos mujiques, onde e quando se encontram cogumelos, etc.? Provavelmente a mesma que tiveram os alunos brasileiros ao lerem uma bela descrição de poucas linhas sobre o mar. Qual não terá sido a reação dos alunos de Tolstói ao lerem esse seu pequeno texto sobre o mar? Provavelmente a mesma dos alunos brasileiros ao lerem sobre os esquimós. Dá-me grande alegria saber pulsar, também entre crianças brasileiras, um pouco da vida da Escola de Iásnaia Poliana. 


\title{
Tempos verbais em “O mujique e os pepinos”, de Lev Tolstói
}

\author{
Quantas vezes eu não invejei o \\ analfabetismo e a ignorância dos mujiques! \\ L. N. Tolstói
}

Por ocasião de minhas leituras de algumas obras de Tolstói, bem como desse trabalho de tradução, fui tomada por momentos de absoluto enlevo. A inteligência, o talento, o dom, a sensibilidade, em uma palavra, a argúcia de Tolstói chegou, muitas vezes, a me estarrecer. Havia sempre muito, e tão intensamente, em tão pouco. E é isso o que tentarei demonstrar na análise gramatical que fiz de um pequeno texto desse escritor, em que tratarei, sobretudo, dos tempos verbais nele empregados.

Meu objetivo neste capítulo será apenas o de indicar e, sempre que possível, justificar a escolha dos tempos verbais empregados na tradução para o português de um pequeno texto, extraído do livro Contos da Nova Cartilha - Primeiro Livro de Leitura $^{149}$. Para tanto, seguem-se: a versão original, em russo; três diferentes versões em português — as duas primeiras, de autoria tradutores cujos nomes, por razões óbvias, não citarei - e a terceira delas, extraída do livro acima citado; por fim, uma versão em língua francesa, de autoria de Charles Salomon, extraída da versão francesa ${ }^{150}$ dos Quatro Livros de Leitura, de Lev Tolstói.

\section{Мужик и огурияь}

(Басня)

Пошел раз мужик к огороднику огуриы воровать. Подполз он к огуриам $и$ думает: Вот дай унесу мешок огуриов, продам: на эти деньги курочку куплю. Нанесет мне курииа яии, сядет наседочкой, выьведет много иьыплят. Выкормлю я цыплят,продам, куплю поросеночка - свинку; напоросит мне свинка поросят. Продам поросят, куплю кобылку; ожеребит мне кобылка жеребят. Выкормлю жеребят,продам; куплю дом и заведу огород. Заведу огород,насажу огуриов, вороват не дам, караул буду крепкий держат. Найму караульщиков, посажу на огуриы, а сам так-то пойду сторонкой да крикну: «Ей вы, караульте крепче!» Мужик так

\footnotetext{
149 TOLSTÓI, L. N. Contos da Nova Cartilha - Primeiro Livro de Leitura. (Trad. M. Aparecida B. P. Soares) $1^{a}$ ed. São Paulo: Ateliê Editorial, 2005.

${ }_{150}$ TOLSTOÏ, Léon. Les Quatre Livres de Lecture. (Trad. Charles Salomon) Paris: Éditions Bossard, 1928.
} 
задумался, что и забыл совсем, что он на чужом огороде, и закричал во всю глотку. Караульщики услыхали, выскочили, избили мужика.

$$
\begin{gathered}
1-\text { O camponês e os pepinos }^{151} \\
\text { (fábula) }
\end{gathered}
$$

Certa vez, um campônio foi a uma horta roubar pepinos. Arrastou-se até eles e pensou: "Vou levar um saco de pepinos, vendê-los e com esse dinheiro comprarei uma galinha. A galinha vai botar ovos, sentar para chocá-los e gerar muitos pintinhos. Criarei frangos, vou vendê-los e comprarei uma porca. A porca me trará leitões. Venderei os leitões e comprarei uma égua. A égua me trará potros. Criarei os potros, vou vendê-los, comprar uma casa e fazer uma horta. Cuidarei da horta, plantarei pepinos e não deixarei que os roubem vigiando-os bem. Contratarei vigias para guardar os pepinos e eu mesmo passarei perto e gritarei: Ei, vocês aí! Vigiem direito!" O campônio enleou-se tanto em seus sonhos que esqueceu-se completamente que estava na horta alheia e gritou a plenos pulmões. Os vigias ouviram, saíram de seus abrigos, apanharam-no e o surraram.

$$
\begin{gathered}
2-\text { O mujique e os pepinos } \\
\text { (fábula) }
\end{gathered}
$$

Certa vez um mujique entrou numa horta pra roubar pepinos. Enquanto rastejava na direção dos pepinos, ele pensava: "Vou levar um saco de pepinos e vender; com o dinheiro, compro uma galinha. A galinha vai botar ovos, vai chocar esses ovos e vão nascer muitos pintinhos. Vou alimentar os pintinhos e, quando crescerem, eu os vendo e compro uma leitoa. Ela me dará outros leitõezinhos. Vendo os leitões e compro uma égua. Ela me dará potros. Alimento os potros e depois vendo. Compro uma casa e faço uma horta. Planto pepinos e não deixo ninguém roubar, vou montar guarda dia e noite. Vou contratar vigias e colocá-los perto dos pepinos, e de vez em quando vou chegar por fora e gritar: ei, vigias, tomem conta direito!”

O mujique estava tão mergulhado nos seus pensamentos que se esqueceu completamente de que estava em quintal alheio, e gritou a plenos pulmões. Foi ouvido pelos vigias daquela casa, que vieram correndo e lhe deram uma surra.

\footnotetext{
${ }^{151}$ Por razões óbvias, preferimos não citar o nome da tradutora dessa versão para o português.

${ }^{152}$ A nota acima também se aplica a essa segunda versão.
} 


$$
\text { 3-O mujique e os pepinos }{ }^{153}
$$

(fábula)

Certa vez, um mujique entrou numa horta para surrupiar pepinos. Enquanto rastejava na direção dos pepinos, ele pensava: Vou levar um saco de pepinos e vendê-los: com esse dinheiro, comprarei uma galinha. A galinha vai botar ovos, vai chocar esses ovos e nascerão muitos pintinhos. Vou alimentar os pintinhos, vou vendê-los e comprar uma leitoazinha; a porquinha me dará outros porquinhos. Vou vender os porquinhos e comprar uma égua; ela me dará potrinhos. Vou alimentar os potrinhos e depois os venderei; vou comprar uma casa e fazer uma horta. Farei a horta, plantarei pepinos e não deixarei ninguém roubar; montarei guarda dia e noite. Contratarei vigias e os colocarei perto dos pepinos, e eu mesmo chegarei de supetão e gritarei assim:

- Ei, vigias, tomem conta direito!

O mujique estava tão mergulhado nos seus pensamentos que se esqueceu completamente de que estava numa horta alheia e gritou a plenos pulmões. Os vigias ouviram, saíram correndo de onde estavam e deram uma surra no mujique.

\section{Le paysan et les concombres ${ }^{154}$}

(fable)

Un paysan alla un jour voler les concombres d'un maraîcher. Il rampa quelque temps sur le ventre et, parvenu tout auprès des concombres, il se dit: «Si j’ai seulement la chance d'en emporter un plein sac, je les vendrai: j'emploierai l'argent à acheter une poule. La poule me pondra beaucoup d'oeufs; elle se mettra à couver; elle mènera à bien nombre de poussins. Je nourrirai les poussins, je les vendrai, j'achèterai une laie en bas âge qui aura des petits cochons. Je vendrai les petits cochons, j'achèterai une jument; ma jument mettra bas des poulains. J'élèverai les poulains, je les vendrai; j'achèterai une maison et ferai un jardin. Oui, j'aurai un jardin, j'y mettrai des concombres, et je ne me laisserai pas voler, je ferai bonne garde. J'aurrai des gardiens à mes gages, je le préposerai à la surveillance des concombres et moi-même, arrivant à la dérobée, je crierai comme ça: «Eh! là-bas, vous autres, faites-donc meilleure garde!» Le paysan était si absorbé dans ses beaux projets qu'il

\footnotetext{
${ }^{153}$ TOLSTÓI, L. N. Contos da Nova Cartilha - Primeiro Livro de Leitura. (Trad. M. Aparecida B. P. Soares) $1^{\text {a }}$ ed. São Paulo: Ateliê Editorial, 2005.

${ }^{154}$ TOLSTOÏ, Léon. Les Quatre Livres de Lecture. (Trad. Charles Salomon) Paris: Éditions Bossard, 1928.
} 
en oublia tout à fait qu'il se trouvait dans le jardin du voisin et il cria «A la garde!» de toutes ses forces. Les gardiens entendirent son appel, se précipitèrent sur lui et le rouèrent de coups.

Inicio a minha análise com uma observação de ordem geral: nenhuma das versões em língua portuguesa traduz огородник como «hortelão»; o mesmo não ocorre na versão em francês, pois maraîcher traduz exatamente o termo russo огородник. Noto igualmente que, embora tenha optado por um adjetivo e um substantivo, "meilleure garde", apenas o tradutor francês parece ter compreendido «Ей вы, караульте крепче!» como circunstância de intensidade: "faites-donc meilleure garde!", ou "tomem mais cuidado, vigiem mais", e não de qualidade, como o fizeram os demais tradutores das versões em português, que, ao invés de "Ei, vigias, redobrem a vigilância", por exemplo, preferiram "Ei, vocês ai! Vigiem direito!" (primeira versão), “[...] ei, vigias, tomem conta direito!” (segunda versão), e “ — Ei, vigias, tomem conta direito!" (terceira versão).

Com exceção de um único verbo, дyмamb, ou «pensar», de aspecto imperfectivo, todos os outros verbos do texto são de aspecto perfectivo. Este verbo indica, portanto, um processo, e não um resultado; é ele que dará início ao pensamento do mujique, a um raciocínio que se desenrolará até quase o final do texto. Depois desse verbo, apenas resultados serão desejados, o que, no texto original, explica o uso do aspecto perfectivo. O próprio desenvolvimento da história atrai resultados e, mais do que ninguém, o protagonista deseja obter resultados. Dá-se, então, tanto no original russo, como na terceira versão em língua portuguesa, uma harmonia entre as escolhas gramaticais, entre o sentido e o desenrolar da história.

É verdade que a frase “Подполз он к огуриам и думает: [...]” apresenta ações consecutivas, e não simultâneas; sendo assim, devo dizer que a primeira versão em português apresenta uma escolha mais correta, a saber: "Arrastou-se até eles e pensou: [...]". No entanto, o verbo «подползти», de aspecto perfectivo, cujo significado é “aproximar-se rastejando", foi, ainda na terceira versão, traduzido por "enquanto rastejava". Ao lado da conjunção "enquanto", o aspecto imperfeito do tempo verbal em português sugere a ideia de que a ação se desenrola ao mesmo tempo em que se desenrola o raciocínio do mujique. Embora a tradutora tenha optado por não acompanhar o aspecto verbal do original russo, a escolha do tempo verbal em português criou uma harmonia importante em relação aos verbos seguintes. Caso sua opção tivesse sido, por exemplo, a de respeitar o aspecto perfectivo do original, bem 
como o tempo verbal, usando, em português, o pretérito perfeito "arrastou-se", ao meu ver seria subtraído um pouco do suspense que, em minha leitura, o início da história fornece:

Aproximar-se. De que forma? Rastejando.

Não haveria tempo para que o raciocínio do mujique se desenvolvesse, e tampouco haveria harmonia entre este tempo verbal "introdutório" e os verbos ainda por vir.

No original, este tempo "cronológico", necessário ao desenvolvimento do raciocínio, parece não existir, pois, como já foi dito, подползти é de aspecto perfectivo, e de tempo passado; no entanto, parece-me que o autor desejava resultados, e talvez seja possível afirmar que esse fato tenha sido compensado pelo verbo думать, que pertence ao aspecto imperfectivo.

O tradutor francês optou pelo passado simples do modo indicativo, um tempo verbal hoje considerado de cunho literário, usado para indicar uma ação ocorrida em um momento bem determinado do passado, e totalmente concluída; é o tempo usado para relatos de acontecimentos históricos, por exemplo, embora, por ser um tempo simples, e, portanto, de leitura mais rápida é, curiosamente, usado hoje nos jornais franceses. Haveria no francês, talvez, a possibilidade de se empregar o passado composto, que, embora também marque uma ação igualmente passada, indica que o acontecimento, ou essa ação, ainda mantém alguma relação com o presente, seja por seus resultados, seja por seus aspectos.

Temos, ainda na versão francesa, a expressão quelque temps, "(por) algum tempo", ausente no original e que, de certa forma, equivale a "enquanto rastejava", da versão em português; e, embora o tradutor tenha usado o passado simples, quelque temps dá ideia de duração. Em seguida, temos parvenu, ou seja, "chegar, alcançar". Esse particípio passado remete-nos ao final do caminho, ao destino do mujique, aos pepinos. Uma etapa foi alcançada, e, agora, o mujique pode pensar. Seguem-se os dois pontos e a fabulosa relação de intenções do protagonista.

Assim como no original russo, aqui também o mujique começa a pensar apenas depois de alcançar a plantação de pepinos. Há, no entanto, na versão francesa, um movimento de duração que nos é transmitido justamente pela expressão quelque temps, ou seja, ele rastejou durante algum tempo, chegou aos pepinos e, então, pensou. 
Se, em português, a opção fosse mais literal, como "arrastou-se e pensou", ocorreria uma perda importante, devido à ideia que diferencia muito claramente a noção de processo e de resultado no russo, e o efeito causado seria uma frase seca. Embora não seja literal, a tradução de M. Aparecida Soares parece-me mais apropriada, pois, ao invés de ser omitida, a possibilidade de obtenção de um resultado é prolongada, dando-nos ideia de continuidade, visto que praticamente todo o texto apóia-se no pensamento do mujique. $\mathrm{O}$ personagem pensa continuamente, mas o resultado apenas ocorrerá no final da história, que sequer começou. Entendo que algo foi acrescentado com ganho nessa versão em português.

Até o momento, o texto deu-nos apenas uma introdução, com implicações na escolha dos tempos verbais, e apresentou problemas de duração; agora, seguem-se os dois pontos, que assinalam o início de tudo.

Minha intenção não é a de discutir os vários acréscimos de termos detectados na versão francesa, mas inexistentes no original russo. Gostaria apenas de registrar que eles ocorrem em vários momentos na tradução de Charles Salomon. Continuemos, então, com os verbos.

Alguns gramáticos dizem que o verbo auxiliar "ir", seguido de infinitivo, resulta em uma fórmula perifrástica, usada como substituta do futuro simples, e indicadora de uma ação futura imediata. Quando ocorre uma conjugação perifrástica, a verdadeira ação, a ação que se quer manifestar e que nos fornece significação principal, é expressa pelo último verbo, ao passo que o verbo auxiliar, ou parte flexional, indica o modo, o tempo e a pessoa, em suma, a ideia acessória da ação.

A conjugação perifrástica, ou locução verbal, formada com o auxiliar "ir" tem, segundo Mattoso Câmara, valor aspectual e valor modal; assinala, portanto, a intenção de fazer algo e, ao mesmo tempo, exprime alguma coisa que ainda acontecerá, o que dá à locução caráter de futuro. Ainda de acordo com ele, "é o caráter modal que propicia o emprego frequente da perífrase com o indicativo presente de "ir" em vez do indicativo presente simples para expressar o futuro na língua coloquial". 155

Essas afirmações ajustam-se à terceira versão em língua portuguesa, pois Tolstói apresenta-nos um mujique, homem simples, portanto, falando — ou pensando —, expressando, enfim, seu desejo de realização, em um contexto em que nada ainda

\footnotetext{
${ }^{155}$ MATTOSO CAMARA JR, J. História e Estrutura da Língua Portuguesa. Rio de Janeiro: Padrão Livraria Editora Ltda, 1979. p. 171
} 
se realizou, mas será — ou, nesse caso, "seria" — realizado brevemente, pois o personagem está prestes a efetuar um furto que desencadeará uma série de outros (possíveis) acontecimentos.

Ao usarmos o modo indicativo, consideramos o fato expresso pelo verbo como certo e real, e o verbo auxiliar "ir" da locução seria, então, interpretado como modal. O modo verbal expresso pela construção "vou levar" assinala que a ação indicada pelo verbo é exercida de maneira real, categórica, definida, transmitindo, assim, atitude de certeza, intenção, ou iminência da realização do fato. Embora no texto original tenhamos вот дай — expressão formada pela partícula вom e o imperativo do verbo damb, uma "possibilidade" ou condição, portanto - ao meu ver, a opção da terceira versão em português não deixa de corresponder ao contexto, pois o mujique está categoricamente decidido a levar consigo um saco de pepinos.

Em língua portuguesa, há indícios de que, se o traço semântico do verbo principal for o movimento, ele será reforçado pelo auxiliar "ir", porque, ele próprio, tem um traço inerente de movimento, por exemplo, "vou ir"; portanto, os verbos principais que acompanham o auxiliar "ir" devem expressar menos movimento e menos deslocamento. Assim, verbos de movimento e de deslocamento devem ser empregados no presente do indicativo, e não em locuções verbais.

$\mathrm{Na}$ terceira versão em português, essa regra foi respeitada, à exceção de "vou levar", em que, embora "levar" seja um verbo de movimento, de deslocamento, seu sentido no texto é de "pegar", "levar consigo", pois o próprio mujique sairá de qualquer forma daquela horta e carregará consigo, ou carregaria, um saco de pepinos. Os outros verbos empregados nessa mesma versão com o auxiliar "ir" têm traços de movimento mais tênues, tais como "botar", "chocar", "alimentar", "vender", "comprar".

Se, com o uso da fórmula criada com o auxiliar "ir", o falante expressa mais intencionalidade e certeza na realização de um ato, ou seja, se expressa intenção aliada à certeza de que a ação será realizada no futuro, isso pode ser constatado na terceira versão em língua portuguesa, visto que, de acordo com minha análise, e embora a condicional exista no original, o mujique tinha verdadeira intenção de realizar seus planos - ou atos —, e estava seguro de levar a cabo sua estratégia. É mais ou menos como se houvesse uma descarga de energia que acompanhasse a firme intenção de realização do ato, bem como a certeza de sua concretização futura, porém, próxima: "Vou levar", “vai chocar", etc. 
J. Mattoso Câmara Jr. nega que a conjugação perifrástica substitua o futuro simples, e afirma que, na linguagem coloquial, o futuro do presente é substituído pelo presente do indicativo ${ }^{156}$. Concordo que o sentido de uma ideia de futuro construída por locução difere do sentido de uma ideia de futuro construída pelo futuro do presente, e que a locução não pode, portanto, substituir o futuro do presente em todo o sentido de tempo futuro que ele nos oferece.

Quando, na fala coloquial, o futuro do presente é substituído pelo presente do indicativo, aponta-se um fato futuro, mas de realização próxima; portanto, o uso de um advérbio é, nesse caso, aconselhável para que se evitem ambiguidades, como em

Vou amanhã.

No que concerne à tradução desse pequeno texto, o conjunto formado pelo auxiliar "ir + infinitivo" indica um futuro próximo ou imediato, portanto, mais próximo do momento presente do que o futuro do presente estaria; por exemplo, na seguinte sequência de etapas:

Vou comprar feijão, (vou) cozinhá-lo, (vou) temperá-lo e, (depois [disso]), farei uma feijoada.

Talvez essa minha impressão esteja fortemente associada ao contexto, em que vemos o futuro do presente como uma consequência de um outro futuro, anterior a ele, expresso pela locução. Por exemplo:

Vou levar um saco de pepinos e [vou] vendê-lo: com esse dinheiro, comprarei uma galinha.

É como se o protagonista dissesse:

Vou levar um saco de pepinos, vendê-lo e, depois, com esse dinheiro, comprarei uma galinha.

Ou ainda:

Se eu levar um saco de pepinos e se eu o vender, comprarei uma galinha.

${ }^{156}$ Ibidem, p. 171. 
Algo parece ser anteriormente necessário para a concretização do futuro. Em outras palavras, a ideia parece já ter se desvinculado do presente sem, no entanto, ter alcançado o futuro, o tempo da conclusão daquilo que ainda não ocorreu. Essa interpretação resgata o verdadeiro significado de вот дай, do original russo: trata-se de uma fórmula popular, comumente empregada em contos maravilhosos, em canções populares, bem como na fala coloquial, e ela expressa uma condição, além de funcionar como uma espécie de "alavanca intencional", ou seja, o início da inspiração, dos planos do protagonista.

Tanto no texto original como no texto da terceira versão, há uma sequência lógica de projetos futuros. Para cada pequena realização, para a realização futura de cada etapa que, na imaginação do mujique, se concretiza com o futuro do presente, seguem-se outras etapas, também no futuro, mas expressas por locuções, o que nos faz insistir em um futuro, digamos, anterior ao futuro do presente, que é, então, a consumação do plano, ou do traçado desse plano.

Cada passo, ou grupo de atos, desencadearia, então, um resultado; desse resultado, outras etapas surgem, desencadeando, por sua vez, outro resultado, e assim sucessivamente, até o planejamento da concretização do desejo do mujique, desejo que não se concretiza, embora sua "receita" fosse perfeita, e apesar do pragmatismo do protagonista.

Criou-se, ou manteve-se, um ritmo precisamente com a alternância das locuções verbais e do futuro do presente. Tratando-se de um texto pedagógico, a repetição das estruturas e, muitas vezes, até a repetição semântica, são bem-vindas. Nesse aspecto, além de obedecer ao original, a terceira versão em português obteve um ganho, porque se negou a ser uma prosa meramente informativa, cuja função seria apenas a de relatar um fato ou contar uma história. A tradutora percebeu que o texto original carrega, silencioso, várias outras informações importantes. O raciocínio do mujique é absolutamente lógico, e essa lógica foi ressaltada com a criação desse ritmo. Desse, ou de outro, como o fez o tradutor francês, mas acredito ser o ritmo indispensável neste caso.

Como já mencionei, o mujique sabia exatamente o que fazer para atingir seu objetivo, o de possuir uma horta como aquela que ele via. $\mathrm{O}$ texto original russo vai em um crescendo até atingir o ápice — ou seja, até o mujique começar a nos revelar as suas ideias - , representado, gramaticalmente, pelos dois pontos, uma espécie de pausa. 
Помел раз мужик к огороднику огуриы воровать. Подполз он к огуриам и думает:

Certa vez, um mujique entrou numa horta para surrupiar pepinos. Enquanto rastejava na direção dos pepinos, ele pensava:

Depois dessa pausa, o ritmo parece acelerar-se graças ao emprego, na terceira versão, do futuro do presente - uma única palavra! - bem como pelo significado dos termos, até o grande final, quando o mujique grita. Por exemplo:

Vou comprar uma casa e fazer uma horta.

E ponto.

Aqui, ainda estamos em uma espécie de "futuro anterior", que se evidencia quando o mujique retoma o seu pensamento:

Farei a horta, plantarei pepinos, e não deixarei roubar [os pepinos], montarei guarda, [...], contratarei vigias. Colocarei esses vigias, gritarei.

Nesse trecho, depois do último verbo, "gritarei", da sequência de futuros simples, a tensão é total, mas ainda um futuro, portanto, um fato ainda por vir. Essa tensão parece chegar ao ponto máximo para, em seguida, enfraquecer, não conseguindo sustentar-se, da mesma maneira como o mujique tampouco pôde manter o próprio controle. Os indicadores dessa ocorrência são o advérbio "assim" e os dois pontos. Esse advérbio abre novamente as portas para o tempo presente, pois ninguém mais duvida de que o mujique vá mesmo gritar; melhor ainda, ele vai nos mostrar como vai gritar. A presença dos dois pontos torna-se engraçada nesse momento, porque parecem estar ali para que não haja dúvida nenhuma, para que ninguém duvide daquilo.

Segue, abaixo, um esquema de opções de tradução referentes à escolha de tempos verbais e, consequentemente, também de ritmo: 
Primeira opção

Segunda opção

vou levar

[vou] vender

comprarei

vai botar

[vai] sentar para chocar

[vai] gerar

criarei

vou vender

comprarei

trará

venderei

comprarei

trará

criarei

vou vender

[vou] comprar

[vou] fazer

cuidarei

plantarei

deixarei

vigiando-os

contratarei

passarei

gritarei vou levar

[vou] vender

compro

vai botar

vai chocar

vão nascer

vou alimentar

vendo

compro

dará

vendo

compro

dará

alimento

vendo

compro

faço

(salto na tradução)

planto

deixo

vou montar guarda

vou contratar

vou chegar

[vou gritar]
Terceira opção

(acredito ser a mais correta)

vou levar

[vou] vender

comprarei

vai botar

vai chocar

nascerão

vou alimentar

vou vender

[vou] comprar

dará

vou vender

[vou] comprar

dará

vou alimentar

venderei

vou comprar

[vou] fazer

farei

plantarei

deixarei

montarei guarda

contratarei

colocarei

gritarei 
O esquema acima evidencia, dentre outros problemas não tratados neste trabalho, a ausência total de ritmo nas duas primeiras colunas, e a manutenção de certo ritmo na terceira coluna:

vou levar, [vou] vender, comprarei.

vai botar, vai chocar, nascerão.

vou alimentar, vou vender, [vou] comprar,

dará, vou vender, [vou] comprar, dará.

vou alimentar, venderei.

vou comprar, [vou] fazer, farei.

plantarei, deixarei, montarei guarda, contratarei, colocarei, gritarei.

Além disso, no que diz respeito sobretudo à sequência final de verbos, fica evidente que a tradutora do primeiro texto desconhece, do começo ao fim, o ritmo que pulsa no original russo e, mais grave, parece desconhecer a ampla gama de possibilidades que nos oferecem a gramática e a estilística da língua portuguesa. A título de exemplo, o uso do gerúndio destrói esse "crescendo" a que me referi, e ignora qualquer tipo de suspense:

plantarei, deixarei, vigiando-os, contratarei, passarei, gritarei.

No segundo texto, o ritmo tampouco existe, e o trabalho foi ainda mais prejudicado devido ao emprego do tempo presente com ideia de futuro, e devido ao uso, em momentos desnecessários, de locuções e advérbios. Nele, além de ritmo, falta o maravilhoso suspense do original:

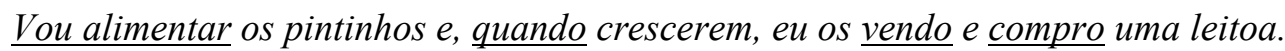

Já na sequência apresentada na versão de M. Aparecida Soares, 
a ausência de locuções é demarcada pela retomada do mesmo termo, como se o mujique respirasse empolgado:

[...] vou comprar uma casa e fazer uma horta.

E ponto final.

Farei a horta $[\ldots]$

Nesse momento, inicia-se a sequência de verbos apenas no futuro do presente.

Ao meu ver, a opção exemplificada na primeira coluna é menos interessante:

vou comprar uma casa e fazer uma horta. Cuidarei da horta [...].

A mudança de verbo (fazer - cuidar), nesse momento, enfraquece o ritmo e, ao mujique, nada mais restaria além de retomar apenas parcialmente o seu raciocínio. O tradutor francês parece haver encontrado uma opção boa, talvez um pouco longa, mas que, embora cause a sensação de certo desandar do compasso desse trecho, não deixa de ser uma pausa importante:

[...] j'achèterai une maison et ferai un jardin. Oui, j'aurai un jardin $[\ldots]$.

Embora ele também tenha optado por empregar dois verbos diferentes (je ferai - j'aurai), respira-se, neste trecho, com a palavra oui, que, por sua vez, retoma e conclui, num só tempo, todo o raciocínio anterior. Se a versão francesa respira com o $o u i$, a terceira versão em língua portuguesa respira com a repetição do mesmo verbo, que, a exemplo do que ocorre no original russo, retoma o raciocínio já exposto e dá sequência ao seu prosseguimento. Para exemplificar, em russo temos:

[...] куплю дом и заведу огород. Заведу огород, насажу огуриов [...]. 
Ao contrário do que ocorre na poesia, em que muitas vezes nos defrontamos com esquemas métricos exatos, o ritmo da prosa baseia-se, fundamentalmente, na variedade, em uma espécie de organização de ritmos da fala corrente.

Segundo René Wellek e Austin Warren, “[...] toda obra de arte é, antes de mais nada, uma série de sons, de que emerge o significado." ${ }^{157}$. Dizem os autores que a importância desse estrato varia, pois não há dúvida de que, em um romance, ela é menor do que em um poema ${ }^{158}$. A fonética, no entanto, é condição prévia e necessária do significado. Acredito que, em textos educativos, o fator "som" seja, igualmente, de grande relevância; e a terceira versão em português levou isso em consideração.

Depois de atrair minha atenção, o som, o ritmo, enfim, o efeito estético detectado nessa pequena prosa passou a interagir com sua semântica, e a análise feita não pôde ser dissociada do conjunto desses componentes.

Quando se lê um texto literário em voz alta, ocorre a "realização de um esquema", acrescida de elementos individuais e pessoais, que tanto podem reforçar o esquema original como ignorá-lo ou distorcê-lo. Meus comentários acerca do texto original, bem como das versões em língua portuguesa e da versão em língua francesa, resultaram de minhas várias "leituras recitativas". Seria tarefa difícil detectar aquilo que, de pessoal, foi acrescentado às minhas observações, bem como os aspectos que, provavelmente, eu tenha ignorado, ou, ainda, as possíveis distorções em minhas leituras.

René Wellek e Austin Warren ${ }^{159}$ ensinam-nos que toda prosa tem uma espécie de ritmo, e que esse ritmo está associado à melodia e à linha de entoação determinada pela sequência de sons. Acredito que, nesse pequeno texto, o ritmo está associado também à sequência do pensamento do mujique, conforme já comentei no decorrer de minha análise.

Tolstói seguramente sabia que a regularidade e a periodicidade podem ser reforçadas por artifícios fonéticos e/ou sintáticos, e que, também nesse conjunto de elementos, baseia-se o esquema rítmico. Talvez seja possível dizer que a interpretação individual e pessoal do sentido de todo o texto levou, efetivamente, a tradutora da terceira versão em língua portuguesa à escolha dos tempos verbais e, por

\footnotetext{
157 WELLEK, René; WARREN, Austin. Teoria da Literatura. $3^{\mathrm{a}}$ ed. Sintra: Publicações EuropaAmérica, 1976. p. 191.

${ }^{158}$ Ibidem, p. 191.

${ }^{159}$ Ibidem, p. 198.
} 
consequência, ao uso cadenciado desses mesmos tempos, o que resultou em um esquema rítmico e compassado, portador de significados.

O texto em questão não pode ser considerado arrítmico, visto que suas frases fluem, e que nelas não se verifica acúmulo de acentos; tampouco pode ser considerado rítmico, pois está longe da regularidade do verso. Seja como for, ele permitiu-me perceber vários compassos, cadenciados em sua maioria.

Depois de constatar que se tratava de uma prosa portadora de ritmo importante, criaram-se conexões, formaram-se paralelismos, e gradações foram identificadas, em resumo, deu-se uma organização.

Wolfgang Kayser questiona, em certa passagem de sua obra, “[...] o sentido de uma frase não resultaria tanto mais claro e intenso quanto esta satisfaz determinadas exigências rítmicas que, em absoluta inconsciência, vivem nos ouvintes?" 160 Minha tendência é a de responder afirmativamente a essa pergunta, mesmo que a prosa atual não se destine mais à recitação.

Para finalizar, ressalto uma observação em relação à estrutura do texto: conforme demonstrado no esquema abaixo, ela é circular, assim como é circular o ciclo da natureza, da mesma forma como é límpida e simples a maneira de raciocinar dos camponeses. Trata-se de uma característica do pensamento mitológico e popular, totalmente diferente do tempo da criação artística em geral.

$\begin{array}{lll}\text { saco de pepino } & = & \text { galinha } \\ \text { galinha } & = & \text { pintinhos } \\ \text { pintinhos } & = & \text { leitoazinha } \\ \text { porquinha } & = & \text { porquinhos } \\ \text { porquinhos } & = & \text { égua } \\ \text { égua } & = & \text { potrinhos } \\ \text { potrinhos } & = & \text { casa } \\ \text { casa } & = & \text { horta } \\ \text { horta } & = & \text { pepinos }\end{array}$

160 KAYSER, Wolfgang. Análise e Interpretação da Obra Literária. Introdução à Ciência da Literatura. (Trad. Paulo Quintela) 6 ${ }^{\mathrm{a}}$ ed. Coimbra: Armênio Amado Editor, 1976. pp. 287 e 288. 
Concluindo, Lev N. Tolstói consegue ser extraordinário em qualquer um de seus textos. Sua genialidade revela-se tanto em longos romances - como Anna Karênina ou Guerra e Paz - como em um breve texto para crianças, com cerca de apenas nove linhas. 
CAPÍTULO IV 


\section{CAPÍTULO IV}

Vida de um soldado

relato de um mujique

Nós vivíamos pobremente, no fim da aldeia. Eu tinha mãe, uma babá (minha irmã mais velha) e uma avó. Vovó usava um corpete velho e uma vasquinha ${ }^{161}$ surrada, cobria a cabeça com um trapo e, no pescoço, usava uma bolsinha pendurada ${ }^{162}$. Vovó amava-me e sentia mais pena de mim do que minha mãe. Meu pai estava no Exército. Diziam que ele bebia muito e, por isso, mandaram-no para o Exército $^{163}$. Como num sonho, lembro-me dele chegando em casa quando estava de licença. Nossa isbá era apertada e sustentada, no centro, por uma forquilha, e, lembrome de como eu subia naquela forquilha e de como caí e machuquei a testa. Desde então, carrego uma cicatriz na testa.

$\mathrm{Na}$ isbá havia duas pequenas janelas e, uma delas, estava sempre vedada com trapos. Nosso quintal era estreito e não tinha cerca. No meio dele havia uma velha selha ${ }^{164}$. No quintal, havia apenas um pangaré velho e torto; vaca, nós não tínhamos, tínhamos duas miseráveis ovelhinhas e um cordeiro. Eu sempre dormia com ele ${ }^{165}$. Nós comíamos um mingau de pão e água. Não havia ninguém para trabalhar: minha mãe vivia com dor de barriga e, vovó, sempre sentada ao lado da piétchka, com dor de cabeça. Só a minha babá trabalhava, mas para si, e não para a família: ela comprava roupas e preparava-se para se casar.

Lembro-me de que a minha mãe ficou mais doente ainda e que, depois, deu à luz um menino. Levaram mamãe para a varanda ${ }^{166}$. Vovó pediu emprestado cereais

\footnotetext{
${ }^{161}$ Saia com muitas pregas na cintura, usada por camponesas. (N.T.)

${ }^{162}$ Era comum entre as camponesas o uso de pequenas bolsas de tecido, ou tecidas, tanto penduradas no pescoço como na cintura. Nelas, guardavam-se sementes, utensílios como faca, colher, etc., e alguma comida que levavam consigo quando saíam para trabalhar nos campos. (N.T.)

${ }^{163}$ A disciplina do Exército é considerada um meio de correção. Antes de 1874, quando, na Rússia, instituiu-se o serviço militar obrigatório, era a comunidade que decidia quem devia ser enviado para o Exército. (N.T.)

${ }^{164}$ Selha de madeira que podia ser usada tanto para deixar a roupa de molho como para o banho da família.

${ }^{165}$ No inverno, famílias muito pobres levavam seus poucos animais para dentro da isbá.

${ }^{166}$ Aqui, é necessário entender o termo "varanda" como um cômodo de frente nas casas rústicas (Dic. Aurélio, acepção 9). A religião ortodoxa considerava que a mulher que acabava de dar à luz uma
} 
ao vizinho e mandou tio Nefiod chamar o pope. E minha babá foi chamar gente para o batismo.

As pessoas chegaram e trouxeram três grandes pães redondos. Os parentes começaram a montar mesas e, depois, estenderam toalhas.

Depois, trouxeram bancos e uma bacia com água. E todos sentaram-se em seus lugares. Quando o pope chegou, o padrinho e a madrinha ficaram na frente, e tia Akulina ficou atrás, com o bebê. Começaram a rezar. Depois, despiram o bebê, o pope pegou-o e mergulhou-o na água. Fiquei assustado e gritei:

- Devolva o bebê!

Mas vovó ficou zangada comigo e disse:

- Cale-se, ou bato em você.

O pope mergulhou-o três vezes e entregou-o à tia Akulina.Titia enrolou-o num pano de algodão e levou-o até a varanda, para minha mãe.

Depois, todos se sentaram à mesa; vovó encheu duas tigelas com kacha ${ }^{167}$, regou com óleo e serviu às pessoas. Quando todos terminaram de comer, deixaram as mesas, agradeceram à minha avó e foram embora.

Fui até minha mãe e perguntei:

— Má, qual é o nome dele?

Minha mãe respondeu:

- O mesmo que o seu ${ }^{168}$.

O menino era magrinho; suas perninhas e bracinhos eram franzinos e ele não parava de gritar. A qualquer hora da noite, ele não parava de gritar, e mamãe ninava-o com cantigas. Ela própria gemia, mas cantava mesmo assim.

Certa vez, levantei-me à noite e escutei mamãe chorando. Vovó levantou-se e perguntou:

— Cristo! O que aconteceu com você?

Mamãe respondeu:

criança permanecia impura durante 40 dias. Сени ou, conf. nossa tradução, «varanda», é um cômodo de fácil acesso, à entrada da isbá, o que evitaria, portanto, a profanação do seu interior. Embora sempre fechada, a varanda é o único cômodo não aquecido, e, obviamente, a história aqui contada não ocorreu no inverno, o que permitia que a mãe fosse instalada fora da isbá propriamente dita. Ademais, também por costume, os pais não assistiam às cerimônias de batismo e de casamento dos filhos. (N.T.)

${ }^{167}$ Mingau muito popular na Rússia. Dependendo da região do país, ele pode ser preparado com vários tipos de grãos, com tubérculos ou com legumes. Na Rússia Central, região de Tolstói, o grão mais usado para o preparo da kacha é o trigo sarraceno. (N.T.)

168 Era comum, na Rússia, que as crianças recebessem o mesmo nome do santo cujo dia era comemorado no dia em que nasciam. O nome era, em geral, escolhido pelo pope. Há, na religião ortodoxa, santos homônimos, cuja festa celebra-se em diferentes dias do ano. (N.T.) 
- A criança morreu.

Vovó acendeu a lamparina, lavou o bebê, vestiu-o com uma pequena camisa limpa, amarrou-o com uma faixa de pano ${ }^{169}$ e colocou-o embaixo dos ícones ${ }^{170}$. Quando amanheceu, vovó saiu da isbá e voltou com titio Nefiod. Titio trouxe duas tábuas velhas e começou a fazer um caixãozinho. Quando ele ficou pronto, titio colocou o bebê naquele pequeno caixão. Depois, minha mãe sentou-se ao lado dele e, com uma voz aguda, começou a se lamentar ${ }^{171}$. Depois, titio Nefiod pegou o caixãozinho, colocou-o debaixo do braço e levou-o para enterrá-lo.

Nós só tivemos alegria quando minha babá se casou. Certa vez, alguns mujiques foram até a nossa isbá, levaram consigo aguardente e pão. E começaram a oferecer aguardente para mamãe. Ela bebeu. Tio Ivã cortou uma fatia de pão e deu a ela. Fiquei de pé, atrás da mesa, e senti vontade de comer um pedacinho do pão. Inclinei-me até mamãe e cochichei-lhe no ouvido. Ela riu, e tio Ivã perguntou:

— O que ele quer? Um pedacinho do pão? - e cortou-me uma fatia grossa.

Peguei o pão e fui para a despensa. Minha babá estava sentada lá. Ela começou a me perguntar:

— O que os mujiques estão falando lá dentro?

E eu respondi:

— Estão bebendo aguardente.

Ela sorriu e disse:

—É que eles estão me pedindo em casamento para Kondrachka.

Depois, começaram a preparar o casamento. Todos acordaram cedo. Vovó acendeu a piétchka, mamãe sovava a massa dos pães e tia Akulina lavava a carne.

Minha irmã calçou coturnos novos, vestiu um $\operatorname{sarafan}^{172}$ vermelho, colocou um xale novo e não ajudava em nada. Depois, quando a isbá ficou aquecida, minha mãe também trocou de roupa, muita gente chegou, e a isbá ficou cheia.

\footnotetext{
${ }^{169} \mathrm{Da}$ vestimenta dos mortos fazia parte um cinto, ou faixa, ambos confeccionados com tecido, e, sobre ele, uma prece inscrita. (N.T.)

${ }^{170}$ Toda casa russa possui o "canto santo", ou seja, um canto entre duas paredes, de frente para a porta de entrada onde, em geral, sobre uma prateleira, ficam os ícones. Sob eles, há uma pequena mesa com velas e o Livro de Orações. A criança morta foi colocada sobre uma mesa como esta. (N.T.)

171 É comum, não apenas na Rússia, mas também em vários países do Leste europeu, prantos e lamúrias em homenagem aos mortos. Tal costume lembra-nos os choros e queixumes das antigas carpideiras. (N.T.)

${ }_{172}$ Típico traje russo, bastante colorido (em geral, vermelho), usado por camponesas, sobretudo, jovens. (N.T.)
} 
Depois, entraram no nosso quintal três pares de cavalos com sinos. E, no último par, estava Kondrachka sentado, com um novo cafetã e com uma chapka ${ }^{173}$ alta. O noivo desceu da telega e entrou na isbá. Vestiram um casaco novo de pele na minha babá e levaram-na até o noivo. Puseram o noivo e a noiva à mesa e as mulheres começaram a cantar. Depois, deixaram a mesa, rezaram a Deus e todos foram para o quintal. Kondrachka acomodou minha babá numa telega e sentou-se em outra. Todos se sentaram nas telegas, benzeram-se e partiram. Eu voltei para a isbá e sentei-me à janela para esperar o retorno do comboio. Minha mãe deu-me uma fatia de pão; comia e logo adormeci. Depois, mamãe acordou-me e disse:

— Eles estão chegando!

Ela deu-me um rolo de massa, e mandou-me sentar à mesa. Kondrachka e minha babá entraram na isbá e, atrás deles, vinha muita gente, bem mais do que antes. A rua estava cheia de gente, e todos nos olhavam pelas janelas. Titio Guerasin era o padrinho do noivo. Ele aproximou-se de mim e disse:

- Saia daí.

Eu fiquei com medo e ia obedecer quando vovó disse:

- Mostre o rolo a Kondrachka e pergunte:

— Você sabe o que é isto? ${ }^{174}$

Eu obedeci. Titio Guerasin colocou dinheiro num copo, verteu vinho em cima dele e deu-o a mim ${ }^{175}$. Peguei o copo e entreguei-o a vovó. Então, nós saímos, e eles sentaram-se.

Depois, começaram a servir vinho, geleia de mocotó e carne de boi; começaram a cantar e a dançar. Serviram aguardente ao tio Guerasin, ele bebeu um gole e disse:

— Esta água está amarga ${ }^{176}$.

\footnotetext{
173 Típico chapéu russo, feito com peles de animais. (N.T.)

174 Trata-se de resquícios do "casamento por rapto", bastante comum na Europa do Leste. Nessa tradição, o noivo finge raptar a noiva, e, no texto em questão, na ausência do pai, o menino era o chefe da casa, portanto, quem devia defender a irmã, ameaçando, com um rolo de massa nas mãos, o noivoraptor. (N.T.)

${ }^{175}$ Trata-se de um resquício de casamentos pré-negociados. Pode igualmente ser entendido como um costume equivalente àquele de se cortar a gravata do noivo e distribuir, entre os convidados, pequenos pedaços do tecido em troca de dinheiro que, para os noivos recém-casados, talvez seja uma ajuda importante. (N.T.)

${ }^{176}$ Em festas de casamentos nas aldeias, é usual que os convidados gritem: “Amargo!”, ou frases como "Esta aguardente parece amarga, é preciso adoçá-la!” para que os noivos se beijem. (N.T.)
} 
Então, minha babá pegou Kondrachka pela orelha e começou a beijá-lo. Cantaram e dançaram durante bastante tempo; depois, todos se foram e Kondrachka levou minha babá consigo para a sua casa.

Depois disso, nossa vida ficou ainda mais pobre. Venderam o cavalo e as últimas ovelhas, e nem sempre tínhamos pão. Mamãe pedia emprestado aos parentes. Logo vovó morreu. Lembro-me de como minha mãezinha gritava e lamentava-se: ${ }^{177}$

- Ah, minha mãezinha querida! Nas mãos de que quem eu, pobre e miserável, fiquei? Nas mãos de quem você deixou a sua infeliz filhinha? Quem, agora, irá me guiar? Como vou viver a minha vida?

E, assim, ela chorava e lamuriava-se muito.

Certa vez, eu fui com outros meninos por uma grande estrada para vigiar cavalos, e vi um soldado caminhando com uma sacola pendurada nos ombros. Ele aproximou-se de nós e perguntou:

— De que aldeia são vocês, meninos?

Nós respondemos:

— De Nikolskóie.

— Ah, então lá vive Matriona, mulher de um soldado?

$\mathrm{Eu}$, então, disse:

- Sim, vive, ela é minha mãe.

O soldado olhou para mim e disse:

— E o seu pai, você o tem visto?

E eu disse:

— Não, não o tenho visto, ele está no Exército.

O soldado, então, disse:

- Bom, vamos, leve-me até Matriona, eu trouxe-lhe uma carta de seu pai.

Eu perguntei:

- Que carta?

E ele respondeu:

— Vamos e você verá.

— Já que é assim, vamos, então.

${ }^{177}$ Ver nota 12. (N.T.) 
O soldado e eu fomos andando, mas ele ia tão rápido que, mesmo correndo atrás dele, eu não o alcançava. Finalmente chegamos a casa. O soldado fez uma prece e disse:

— Saudações!

— Depois, tirou o casaco, sentou-se no parapeito da janela, começou a olhar toda a isbá e disse:

— Como? Sua família é assim pequena? Minha mãe ficou com vergonha e não disse nada, só olhou para o soldado. Então, ele perguntou:

— Onde está mamãe?

E começou a chorar. Então, minha mãe correu até meu pai e começou a beijálo. Eu também pulei voando nas suas pernas e comecei a abraçá-lo. Ele parou de chorar e desatou a rir.

Depois, chegaram os vizinhos, meu pai cumprimentou todos e contou-lhes que, então, já o tinham totalmente dispensado.

Quando trouxeram o gado, minha babá chegou e beijou meu pai. Papai perguntou:

— Quem é essa moça?

- Minha mãe riu e perguntou:

— Não reconhece a sua própria filha?

- Papai chamou-a para perto de si, beijou-a e perguntou-lhe como ela estava. Depois, mamãe foi fritar ovos, e mandou minha irmã pegar aguardente. Minha irmã pegou uma botija fechada com papel e colocou-a sobre a mesa. Papai perguntou:

— O que é isso?

- Aguardente para você.

Ele, então disse:

— Não, há cinco anos eu não bebo; só quero ovos. Ele fez uma prece, sentouse à mesa e começou a comer. Depois, ele disse:

- Se eu não tivesse parado de beber, não teria sido sargento e não teria trazido nada para casa, mas, agora... graças a Deus.

E ele tirou da sacola um embrulho com dinheiro e deu-o a minha mãe. Mamãe ficou feliz, pegou logo o dinheiro e guardou-o.

Depois, quando todos foram embora, papai deitou-se para dormir no banco do fundo, e acomodou-me junto com ele, e mamãe deitou-se conosco, no pé da cama. E eles conversaram muito tempo, quase até a meia-noite. Depois, eu dormi. 
Na manhã seguinte, mamãe disse:

- Ah, acabou a lenha!

E papai perguntou:

— Você tem um machado?

— Tenho sim, mas um machado ruim.

Papai calçou-se, pegou o machado e foi para o quintal. Corri atrás dele.

Papai puxou uma vara comprida do teto, colocou-a num cepo, ergueu o machado, rachou-a depressa, levou-a para a isbá e disse:

- Pronto, aqui está a sua lenha, acenda a piétchka; e hoje eu vou procurar uma isbá para comprar, e madeira para armazenar. Tenho de comprar uma vaca também.

Mamãe disse:

- Ah, é preciso muito dinheiro para tudo isso.

E papai disse:

— Podemos trabalhar. Veja, o mujique já está crescendo. - E papai apontou para mim.

Papai fez uma prece, comeu um pedaço de pão, agasalhou-se e disse a mamãe:

- Se tiver ovos frescos, então asse-os para o almoço no meio das cinzas. E foi embora.

Ele demorou a voltar. Eu comecei a pedir a mamãe para me deixar ir procurálo. Ela não deixou. Mesmo assim, tentei ir, mas mamãe não deixou e deu-me um tapa. Sentei-me na piétchka e comecei a chorar. Então, papai entrou na isbá e perguntou:

— Por que você está chorando?

Eu respondi:

— Eu queria correr atrás de você, mas mamãe não deixou, e ainda me bateu.

E chorei mais ainda. Papai riu, foi até mamãe, e começou a bater nela de brincadeira, dizendo:

- Não bata no Fedka, não bata no Fedka!

Mamãe fingiu chorar, papai riu e disse:

- Mas você e o Fedka, vocês dois são manteiga derretida, choram por qualquer coisa. Depois, papai sentou-se à mesa, acomodou-me ao seu lado e gritou:

— E agora, mãe, traga logo o almoço: eu e Fedka estamos com fome.

Mamãe deu-nos kacha e ovos, e nós começamos a comer. Então, ela perguntou: 
— E então? comprou madeira para a isbá?

E papai respondeu:

- Comprei: oitenta rublos de tília, branca como vidro. É preciso esperar, vamos comprar aguardente para os mujiques, e eles trarão a madeira num domingo.

Desde então, nós passamos a viver bem. 


\section{Observações}

Não encontrei nada na literatura russa que possa se comparar a essas páginas. No episódio do retorno do pai não há sequer uma alusão à emoção implícita no fato; o texto nada contém além daquilo que ocorreu e, do ocorrido, apenas o indispensável para que o leitor compreenda a situação de todos aqueles que vivem na história.

A respeito do texto "Vida de um Soldado", Charles Salomon, contemporâneo de Tolstói e um de seus tradutores para o francês, conta-nos que Fedka - ou Vaska Morózov - e Ignatka Makárov, ambos alunos de Tolstói, são seus co-autores ${ }^{178}$, o que contraria a versão do próprio Fedka; segundo ele, o texto escrito em conjunto não apenas com Makárov, mas também com Tolstói, fora destruído por obra das diabruras de algumas crianças de Iásnaia Poliana e estava definitivamente perdido. Ainda de acordo com Fedka, "Vida de um Soldado" foi escrito apenas por ele, após a destruição do texto anterior.

Segundo o mesmo tradutor, Paul Boyer e Speránski publicaram-no em francês, acompanhado de notas bastante ricas. A seguir, a tradução de uma passagem extraída, por Salomon, da versão de Boyer; nela, Tolstói explica a origem desse mesmo texto:

Naquele ano - escreve Tolstói - Fedka e alguns outros alunos passavam uma parte das férias em minha casa. Um dia, depois do banho, cansados de brincar, inventaram fazer alguma tarefa escolar. Propus a eles que escrevessem uma composição e sugeri-lhes vários temas... dentre outros, o seguinte: a história de uma criança muito pobre, cujo pai, alcoólatra e preguiçoso, é mandado para o Exército devido a sua má conduta, e de onde volta disciplinado, curado. Se eu fosse vocês - disse-lhes eu - eis como eu faria: contaria que, quando eu era bem pequeno, eu tinha pai, mãe e alguns outros parentes; depois, que meu pai bebia e batia na minha mãe, e que ela vivia chorando; depois, que ele havia sido escolhido para ser recrutado, e [contaria] sobre os gritos de minha mãe no dia em que ele foi embora; enfim, [eu contaria] como ele voltou e como eu não o reconheci imediatamente; [contaria] como ele perguntou a mim se Matrona, sua mulher, vivia ainda, e a alegria que foi a sua volta, e quanto, a partir de então, nossa vida melhorou. Eu não lhes disse nada além disso, e Fedka gostou muito do tema. Em seguida, ele pegou uma pena, papel, e pôs-se a escrever. Enquanto ele escrevia, sugeri-lhe a ideia da irmã e o episódio da morte da avó. Todo o resto, ele escreveu sozinho, sem ajuda e, à exceção do primeiro capítulo, não me mostrou mais nada até que não tivesse concluído... No dia seguinte, ele já nem pensava mais

178 TOLSTOÏ, Léon N. Les Quate Livres de Lecture. Trad. e pref. Charles Salomon. Paris: Éditions Bossard, 1928, p. 508. 
sobre o que havia escrito. Acrescentei o título, dividi em capítulos, corrigi alguns erros cometidos por pura distração...

Nesse ponto, segundo Salomon, termina a versão de Paul Boyer e de Speranski. Traduzimos a continuação desse mesmo texto, agora na versão de Charles Salomon:

Quando ele me mostrou o primeiro capítulo, comecei a lê-lo e senti que Fedka estava muito agitado: ele prendia a respiração e acompanhava com os olhos ora a minha leitura do manuscrito, ora a minha impressão, que ele tentava adivinhar no meu rosto: estaria eu aprovando ou desaprovando?

Quando eu lhe disse que estava muito bom, ele ficou todo vermelho; sem dizer palavra, nervoso, um tanto impaciente, Fedka foi gravemente até a mesa, colocou o caderno sobre ela e saiu lentamente. Naquele dia, ele brincou no quintal como louco com seus companheiros de brincadeiras e, quando nossos olhares encontraram-se, seus olhos estavam cheios de reconhecimento e de carinho.

Ainda de acordo com Charles Salomon, a versão original de Fedka foi, posteriormente, bastante modificada e reduzida por Tolstói. Várias passagens foram suprimidas, enquanto outras foram acrescentadas. 


\title{
Recordações de um aluno da Escola de Iásnaia Poliana
}

\author{
Eu nunca perdi e não perderei jamais a lembrança daqueles \\ dias límpidos e felizes. O amor por Lev Nikoláievitch, que \\ então se irradiou em mim, resplandeceu luminoso em minha \\ alma e clareia a minha vida. \\ Vaska S. Morózov, cocheiro em Tula.
}

Em 1859, no início do outono, soubemos, na aldeia de Iásnaia Poliana, do desejo de Lev Nikoláievitch — “o conde”, como nós então o chamávamos — de criar ali uma escola, gratuita e aberta às crianças que desejassem estudar. Lembro-me da agitação que aquilo provocou, das reuniões e dos mais variados rumores na aldeia.

Como? Por quê? Será que não é enganação? Não é tão fácil assim ensinar de graça! Sem dúvida haverá cerca de cinquenta crianças, ou mais.

Tudo ficou combinado para terça-feira, um dia praticamente livre. Naquela manhã, levantei-me cedo, aproximei-me da janela e olhei para fora para ver se as crianças estavam se reunindo. Não havia grupos, apenas alguns colegas que corriam de casa em casa. Ora Danilka ia até a casa de Semka, ora Semka ia até Ignatka, ou Taraska até Nikichka... Todos já estavam prontos: blusas brancas e limpas, alpargatas novas, cabelos lustrosos de óleo ou de manteiga, conforme o que havia em casa... Alguns minutos mais tarde, estávamos na frente da casa do professor...

— Bom dia! Vocês trouxeram seus filhos? — perguntou Lev Nikoláievitch aos pais.

- Sim, vossa senhoria, responderam os adultos, cumprimentando-o.

- Muito bem, fico muito feliz - disse ele sorrindo e olhando para todos.

Ele percorreu rapidamente a multidão com os olhos, procurando as crianças que se escondiam atrás do pai ou da mãe. Depois, abriu passagem e perguntou ao primeiro menino:

-Você quer aprender?

$-\operatorname{Sim}$.

— Como você se chama?

- Danilka.

— E o seu sobrenome?

- Kozlov.

— Está bem, nós vamos aprender.

E ele começou a interrogar cada um dos meninos. 
— Você, como se chama?

— Ignatka Makárov.

- E você?

- Taraska Fokanov.

Ao se virar para o outro lado, Lev Nikoláievitch deparou-se com minha irmã.

— Você também veio aprender? Você quer? Que as meninas também venham. Todos vamos estudar.

- Não, eu não vim para aprender, é isso. - minha irmã falava, choramingando timidamente.

Depois, chegou a minha vez.

- E você, também quer aprender?

Eu estava parado na frente do professor, olhando nos olhos dele, tremendo como uma folha.

— Sim — disse eu timidamente.

- Como você se chama?

- Vaska.

— Você sabe o seu sobrenome? - perguntou ele, e eu tive a impressão de que ele me olhava como se eu fosse um gato franzino.

- Sim.

- E qual é?

- Morózov.

— Eu não vou me esquecer. Morózov Vaska, o gato ${ }^{179}$.

Ele sorriu, e seu rosto pareceu-me ser de aprovação. Era como se já nos conhecêssemos antes.

— Vamos, Morózov, Makárov, Kozlov, venham comigo. E, vocês, voltem para casa. Vou mostrar a escola a eles, mandem mais crianças. As meninas também. Todos vamos aprender.

Uma semana de estudos passou, depois outra e, em seguida, um mês inteiro. $\mathrm{O}$ outono terminou sem que percebêssemos. O inverno chegou. Nós já estávamos bastante familiarizados com a escola, estávamos acostumados com Lev Nikoláievitch. Um dia, ele disse-nos: "Não me chamem de 'vossa senhoria'. Meu nome é Lev

\footnotetext{
${ }^{179}$ Na Rússia, é comum que gatos recebam o nome Vaska, diminutivo de Vassíli (Basílio). (Nota da tradução para o português).
} 
Nikoláievitch, então, chamem-me assim." Desde então, nunca mais lhe dissemos "vossa senhoria".

Três meses ainda não haviam decorrido, e nosso estudo ia a todo vapor. Nós já líamos com facilidade e, de 22 alunos do começo, tínhamos passado a 70.

Os 70 cercavam Lev Nikoláievitch, alguns fazendo perguntas, outros mostrando o caderno.

— Lev Nikoláievitch, eu escrevi certo? — perguntava-lhe um.

Ele olhava.

— Está certo, é isto. Mas, aqui, você esqueceu alguma coisa, fora isso, está certo. Vá com calma.

- E eu, eu escrevi direito? - pergunta-lhe outro, depois um terceiro, e a classe inteira.

Ele olha com atenção, aprova com gentileza, às vezes faz observações...

Toda a sua boa vontade, tão cheia de entusiasmo, encorajava-nos, e nosso estímulo aumentava dia após dia. Durante o recreio, serviam-nos almoço. Nós brincávamos, divertíamo-nos.

— Querem comer e passear um pouco? — perguntava Lev Nikoláievitch. Eu também quero. Então, vamos ver quem é que será o primeiro a sair.

Nós descemos as escadas, para ver quem seria o primeiro, soltando gritos agudos atrás de Lev Nikoláievitch. Ele pula os degraus de três em três, distanciandose de nós. Nossa pequena turma inteira corre atrás dele.

— Eu já volto - diz ele, desaparecendo na ala da casa onde morava.

Dispersamo-nos por todas as sendas do jardim. Lev Nikoláievitch volta logo. Mais jogos, barulho, gritos, farra, pulamos na neve e lançamos bolas.

- Vamos, atirem-se todos em mim! Vamos ver se vocês conseguem me derrubar.

E nós cercamos Lev Nikoláievitch, penduramo-nos nele, atrás e na frente, passando-lhe rasteiras; lançamos bolas de neve nele, atiramo-nos nele e escalamos as suas costas, tentando, obstinadamente, derrubá-lo. Mas ele é mais obstinado ainda e forte como um boi, e carrega-nos sobre as costas. Pouco depois, de cansaço, mas na maior parte das vezes, para se divertir, ele cai na neve. Que entusiasmo indescritível! No mesmo instante, nós o cobrimos de neve e pulamos todos juntos sobre ele, gritando: "O monte não é grande, o monte não é grande!" 
Essas alegrias, esses jogos, nossos rápidos progressos na escola aproximaramnos muito de Lev Nikoláievitch. Sofríamos quando não estava conosco, e o mesmo acontecia com ele. Éramos inseparáveis, e deixávamo-nos apenas quando já era bastante tarde. Passávamos o dia na escola e, à noite, desfrutávamos até à meia-noite no terraço. Ele contava histórias, falava da guerra, de sua tia degolada por um cozinheiro em Moscou, de caça, como um urso por pouco não o matara, e mostravanos uma marca perto do olho, no lugar arranhado pela pata do animal...

Um dia de festa, não me lembro mais de qual, mas era no final do mês de agosto, já que a colheita acabava de começar, nós estávamos sentados no terraço com Lev Nikoláievitch. Todos os melhores alunos, os mais velhos, estavam lá. Nós conversávamos, brincávamos, falávamos sobre tudo e sobre nada, abordando algumas vezes assuntos sérios que demandam atenção e reflexão.

Lev Nikoláievitch falava-nos, por exemplo, da guerra, de tudo o que ele havia visto nela: os mortos, os feridos, os doentes, os médicos que serram pernas, cortam braços e extraem olhos atingidos por balas. Escutando esses relatos horríveis, quase todos os alunos encolhiam o próprio corpo.

— Agora vou lhes falar sobre a minha nova ideia — diz Lev Nikoláievitch. Isso lhes interessa?

— Sim, sim! — respondemos em coro.

— É o seguinte - começa Lev Nikoláievitch — eu quero abandonar a minha propriedade, minha vida de senhor, tornar-me camponês, construir uma casa no fim da aldeia, casar-me com uma jovem camponesa; trabalharei como vocês, ceifarei, lavrarei, ou seja, farei tudo.

- Ah, um batrak ${ }^{180}$ — diz Ignat, para provocar risos em todos.

— Por que um batrak? Eu trabalharei para mim, para a minha família.

— Mas, então, o que o senhor fará com os seus bens? - perguntamos.

— Que bens? A terra? Nós vamos reparti-la, a de vocês e a minha, ela será comum, seremos iguais.

- E se alguém zombar do senhor: nossa, o Tolstov ${ }^{181}$, um nobre arruinado, que miséria, ele trabalha sozinho, o senhor não ficará com vergonha? - perguntamos a ele.

\footnotetext{
${ }^{180}$ Camponês contratado por proprietários. (N.T. francês)

${ }^{181}$ Variante popular de Tolstói. (N.T. francês)
} 
Lev Nikoláievitch martelou essas palavras como se estivesse na presença de adultos:

— Onde é que vocês veem a vergonha? Em trabalhar para si próprio? Seus pais já lhes disseram que eles tinham vergonha de trabalhar? Não! Então, onde é que vocês veem vergonha se um homem alimenta-se e alimenta a sua família fazendo um trabalho honesto? É justamente do contrário que eu tenho vergonha... Acho que não é ridículo trabalhar, mas acho que é vergonhoso e escandaloso ficar ocioso e viver melhor do que vocês. Eu bebo, como, monto a cavalo, toco um instrumento e, mesmo assim, fico entediado, acho que sou um vadio.

Lev Nikoláievitch olha fixamente para Ignat, lança um olhar na minha direção e na direção dos outros e diz:

— E então, Ignat, como é que vamos decidir?

Para nós era um problema novo, surpreendente, de que nunca havíamos ouvido falar, muito complicado. Até Ignat, por mais tagarela que fosse, não soube o que responder na hora. Calamo-nos, perplexos, desconfiados da ideia de Lev Nikoláievitch. Creio que todos se perguntavam se ele estava falando sério ou brincando: como um nobre pode se tornar um mujique...

Finalmente, soltamos a língua, começamos a discutir esses problemas complicados: como casar Lev Nikoláievitch, como instalá-lo em algum lugar, escolher para ele a melhor noiva, a mais trabalhadora; se não encontrássemos nenhuma na nossa aldeia, seria preciso procurar em outro lugar, em Kaznatcheievka ou em Baburino. "Casar não é nada, depois é que se tem de prestar atenção; não se livra da mulher como se livra de um sapato." Assim, nós dávamo-lhe as mais detalhadas lições.

Sentado, ele olhava para nós de vez em quando, sorria, respondia uma coisa ou outra, e tomava notas no seu caderno...

Lev Nikoláievitch quase nunca se separava de nós. Ele era particularmente apegado aos primeiros alunos, os melhores. Os estudos eram sérios. Ele parecia extrair alguma coisa profunda da alma dos alunos.

Nós nos demorávamos sempre na escola. Os alunos dos segundo e terceiro anos iam embora, mas nós ficávamos lá boa parte da noite, pois Lev Nikoláievitch gostava de ler conosco. Nosso livro preferido da noite era Robinson Crusoé. Eu lia com rapidez e com clareza; Tchernov e eu éramos encarregados da leitura. E, quando ficávamos até tarde, até meia-noite, absortos em um livro, nos contos e nas 
brincadeiras, Lev Nikoláievitch levava-nos para casa em sua carruagem quando fazia mau tempo...

Um dia, estávamos lendo alguma coisa com Lev Nikoláievitch. Não me lembro mais do título, mas era um livro muito bom. Eu fazia várias perguntas a Lev Nikoláievitch, detendo-me em alguns trechos:

— Lev Nikoláievtch, o senhor também pode escrever assim?

— Não sei.

Depois da leitura, ele nos disse:

- Nós também vamos escrever, inventar alguma coisa...

Ele pedia-nos que escrevêssemos inspirando-nos em provérbios, mas não saía nada. Um dia, pusemo-nos a escrever uma composição a três: Lev Nikoláievitch, Makárov e eu, Morózov. Estava dando certo. Ora Lev Nikoláievitch dizia alguma coisa, ora Makárov, ora eu. Nenhum de nós cedia aos outros, parecíamos escritores do mesmo calibre. Tínhamos escrito uma folha inteira e começado a segunda. Lev Nikoláievitch estava radiante com o nosso sucesso e repetia:

—Mas que bom! Deus nos permita terminar, nós mandaremos imprimir, será um livro.

Eu começava a ficar com ciúmes porque aquele livro escrito em conjunto ia ser só de Lev Nikoláievitch: as pessoas leriam e diriam: "O autor é Lev Nikoláievitch." Pouco disposto a lhe ceder aquilo que havíamos inventado juntos, perguntei-lhe:

— Como o senhor irá publicá-lo, Lev Nikoláievitch?

Lev Nikoláievitch olhou-me sem entender.

- Nós vamos publicá-lo tal qual.

Mas, Lev Nikoláievitch, o senhor vai imprimir o nome de nós três? Por exemplo, em ordem alfabética: Makárov, Morózov, e qual é o seu sobrenome?

- Tolstói.

— Então, o senhor vai pôr assim: Makárov, Morózov e Tolstói.

Lev Nikoláievitch sorriu e concordou:

— Sim, vamos imprimir os três sobrenomes.

Lástima, não conservei nenhuma lembrança de nossa "obra célebre", como Lev Nikoláievitch chamava-a. Esqueci-me de tudo. E, infelizmente, nossa obra não se concretizou. Os alunos aniquilaram-na para fazer mata-moscas. E, durante muito 
tempo, Lev Nikoláievitch lamentou nossa composição, indignando-se com os traquinas.

Eu tentei reconstituir o que havíamos perdido, reescrever palavra por palavra. À noite, passando na frente da casa de Lev Nikoláievitch, Makárov e eu começamos a trabalhar. Mas sem sucesso. Nós nos esforçávamos, mas não nos lembrávamos do essencial. Acabamos escrevendo o texto outra vez, mas não tão bem, e Lev Nikoláievitch lamentava sempre o original. No entanto, ele não abandonava a sua ideia, e disse-me:

- Morózov, escreva você mesmo alguma coisa.

— Mas o quê, Lev Nikoláievitch?

- Descreva as suas primeiras lembranças, quando você tinha cinco ou seis anos. Como vocês viviam e como você se lembra da sua vida de maneira geral.

— Está bem, Lev Nikoláievitch.

- E comecei a escrever, bastante e quebrando a cabeça. Eu mostrava para Lev Nikoláievitch o que eu escrevia e ele dizia sempre:

— Bom, muito bom!

Eu continuava com dedicação, e Lev Nikoláievitch olhava e dizia de novo:

- Bom, muito bom! Continue.

Insisti em minha "obra", mas aquilo começou a me aborrecer. Já estava longa demais e eu queria terminá-la logo.

No final, escrevi: "Desde então, nós vivemos bem"; entreguei-lhe e disse:

— Lev Nikoláievitch, olhe, será que já não está bom?

Lev Nikoláievitch leu e disse:

— Bom, muito bom! Dobrou meu texto e guardou-o.

- Vou mandar imprimir.

Bem no fundo de mim, eu não acreditava. Mas logo pude ler o meu conto impresso. Vida de um simples soldado, foi assim que Lev Nikoláievitch intitulou-o...

Lev Nikoláievitch propôs fazermos uma viagem. Ele tinha de ir ao distrito de Samara para se curar com kumys (leite de égua fermentado).

Lev Nikoláievitch devia ir comigo e com meu companheiro Tchernov, e também com Alexei Stepanovitch ${ }^{182} \ldots$

\footnotetext{
182 Alexei Stepanovitch Oriekhov. Administrador de Iásnaia Poliana. (Nota da tradução para o
} português.) 
Apesar da viagem cansativa, paramos apenas na última estação de muda. Era a minha vez de segurar as rédeas. A tarde caía, e logo anoiteceu. Depois, foi Moscou, de que eu tanto tinha ouvido falar. Como as luzes brilham! Tudo é iluminado, as casas são enormes, e quanta gente, quanta gente! Não se sabe mais para qual lado olhar!

A voz de Lev Nikoláievitch retumba do tarantasse ${ }^{183}$ :

- Cocheiro, leve-nos ao hotel.

- Que hotel, senhor?

— Leve-nos primeiro para a rua Piatnitskaia, em seguida eu mostrarei.

O hotel ficava a quase meia versta, e estava iluminado como se fosse pleno dia. Lev Nikoláievitch pediu um aposento com três quartos.

- Graças a Deus, vamos poder descansar. Estão gostando de Moscou? perguntou ele.

— É bonita — nós respondemos. Que casas! Que gente!

— Eu não gosto de Moscou — replicou Lev Nikoláievitch.

— Mas por quê? — nós fizemos, espantados.

- Aqui não há campos, florestas e jardins como onde vivemos, não há pássaros nem ovelhas, nada para ser admirado e nenhum lugar para se passear ao ar livre, é triste.

Nós não concordávamos com ele. Era tudo tão novo para nós...

De Kazan, fomos até Samara, depois, já cansados de viajar, percorremos 130 verstas em carruagem. Finalmente chegamos, Deus seja louvado! Ao redor, a estepe, nem aldeia, nem floresta, nem moitas, apenas tendas de feltro. Estendemos os tapetes no chão mesmo, e um pedaço de feltro que serviria de cama para Lev Nikoláievitch. Nossa tenda era grande como uma isbá, redonda, erguida sobre estacas, coberta com pedaços de feltro bastante limpos e esticados sobre ripas de madeira. Ela ficava entre outras [tendas] dispostas em duas fileiras, uma de frente para outra...

Quinze dias se passaram muito rapidamente. Sentíamo-nos bem entre os bachkirs ${ }^{184}$, estávamos acostumados com eles, e eles, conosco. Velhos e moços amavam Lev Nikoláievitch; ele sabia como se aproximar deles: com os velhos, ele

\footnotetext{
${ }^{183}$ Espécie de carruagem rústica, puxada por três cavalos, usada sobretudo no inverno. (Nota da tradução para o português)

${ }^{184}$ Embora as origens dos bachkirs pareçam ainda pouco conhecidas, costuma-se dizer que são povos de origem turca que, desde o século X, ocupam as regiões compreendidas entre os montes Urais e o rio Volga. (Nota da tradução para o português).
} 
conversava sobre religião, sobre Deus, sobre Alá; com outros, ele brincava, ria ou, então, jogava seus jogos. E assim era cada dia. Cada um amava-o à sua maneira.

Os bachkirs tinham se afeiçoado a ele; cada vez que o encontravam, sorriam alegremente e inclinavam a cabeça, cumprimentando-o. Até mesmo as crianças pequenas sorriam quando o viam e chamavam-no de "Príncipe de Tula", arranhando as palavras.

Lev Nikoláievitch participava com frequência dos jogos dos bachkirs. Todos jogavam, os mais velhos, os mais jovens, Tchernov e também eu. Por exemplo, pular canguru: várias pessoas enfileiravam-se, uma atrás da outra, e nós pulávamos, um por vez. Lev Nikoláievitch era leve, pulava alto e com mais habilidade do que os outros. Divertíamo-nos também com um jogo que, em bachkir, chama-se pchaloilé, se não me falha a memória.

Desenhávamos um círculo no chão, com um buraco no meio; pegávamos várias bolas que deviam ser empurradas com varas para o buraco, depois tirávamo-nas com mais um golpe de vara e corríamos atrás para apanhá-las; esqueci-me dos detalhes desse jogo, mas lembro-me de que ríamos muito. Algumas vezes, Lev Nikoláievitch lutava com os bachkirs. Ele gostava muito de lutas. Era um verdadeiro Hércules, e ele não tinha adversários do seu tamanho. Apenas um bachkir igualava-o em força, e Lev Nikoláievitch não conseguia jogá-lo no chão, mas o bachkir tampouco podia derrubá-lo. Ofegante, Lev Nikoláievitch dizia-lhe:

— Não, eu não aguento mais, você é mais forte do que eu.

Durante esses jogos, todos os bachkirs, jovens e velhos, saíam de suas tendas e juntavam-se em volta.

MORÓZOV, V.S. In: OPULSKAIA, L. Tolstö̈ vu par lui-même et ses contemporains. Trad. para o francês M. Fainbaum. Moscou: Éd. du Progrès, 1977, pp. 99-108. 


\section{Algumas observações sobre a tradução desse texto}

Embora o verbo francês apprendre possa, em português, ser traduzido por “ensinar" ou por "aprender", já que ele carrega o duplo sentido de "buscar a aquisição de conhecimento" e "fornecer conhecimento", optei, na tradução deste texto, por apenas uma das duas possibilidades — "buscar a aquisição de conhecimentos" sempre que o verbo foi empregado no texto francês. Para tanto, fui diretamente guiada pelo próprio conteúdo do relato aqui traduzido e, de maneira menos direta, mas igualmente importante, também pelo contexto geral em que se insere esta fase pessoal e literária de Lev Tolstói.

Para precisar a minha escolha, gostaria de lembrar, conforme já disse, que Tolstói tinha uma visão pessoal da pedagogia, porém ampla e extremamente arrojada. Ele aprendia também com os seus alunos. A seguir, alguns exemplos:

"Bon, nous allons apprendre." - "Está bem, (nós) vamos aprender."

"Nous allons tous apprendre." - "Todos nós vamos aprender."

Nota-se uma sutil diferença entre o significado das duas frases em língua portuguesa: o pronome adjetivo indefinido "todos", no segundo exemplo, restringe a possibilidade de traduzirmos o verbo apprendre por "ensinar". Gramaticalmente, assim como no primeiro exemplo, o pronome pessoal "nós" é plural, o que, obviamente, leva-nos a considerar o conjunto, ou seja, Tolstói e as crianças, ou Tolstói e outros professores. O contexto informa-nos que se tratava do primeiro dia de aula e que Tolstói recrutava mais alunos; embora ele fosse o professor, não me pareceu adequada a opção por "Todos nós vamos ensinar." O primeiro exemplo, ao contrário, parece-me aceitar mais naturalmente a versão "Está bem, vamos ensinar." Por motivos já expostos, a opção foi rejeitada na tradução para o português.O pronome "todos", ausente no primeiro exemplo, parece aproximar Tolstói dos alunos, ao passo que a ausência dele, no outro exemplo, dar-me-ia a escolha de, naturalmente, optar por traduzir apprendre por “ensinar”. Vejamos a sequência de diálogos: 
- Tu veux apprendre?

- Oui.

$-[\ldots]$

- Bon, nous allons apprendre.

— Você quer aprender?

- Sim.

$-[\ldots]$

— Está bem, nós vamos aprender.

— Você quer aprender?

- Sim.

$-[\ldots]$

— Está bem, nós vamos ensinar.

Separadas do contexto, ambas as opções de tradução estariam absolutamente corretas em português, não obstante, uma lógica imediata levou-me a preferir a segunda. Deixei-me conduzir por essa lógica, demonstrada pelo próprio texto ao leitor, no decorrer da leitura. Preferi seguir minha intuição, ceder ao caminho que me indicou algumas leituras prévias sobre o tema, mesmo que, para isso, arrisque parecer ter cometido uma falha. 


\title{
Correspondência entre L.N. Tolstói e M.K. Gandhi
}

\author{
"[...] Dormi mal. Passeei. Escrevi uma carta ao hindu e recebi uma simpática \\ carta do hindu do Transvaal. A carta para o hindu está muito fraca". \\ “[...] Nada fiz de manhã. Escrevi uma carta para o hindu”. \\ 24 de setembro de 1909. \\ L. N. Tolstói, Diários.
}

\section{$\underline{\text { Primeira carta escrita por Gandhi e endereçada a Tolstói }}$}

London,

October 1, 1909

Sir,

I take the liberty of inviting your attention to what has been going on in the Transvaal (South Africa) for nearly three years.

There is in that Colony a British Indian population of nearly 13.000. These Indians have, for several years, laboured under various legal disabilities. The prejudice against colour and in some respects against Asiatics is intense in that Colony. It is largely due, so far as Asiatics are concerned, to trade jealousy. The climax was reached three years ago, with a law which I and many others considered to be degrading and calculated to unman those to whom it was applicable. I felt that submission to a law of this nature was inconsistent with the spirit of true religion. I and some of my friends were and still are firm believers in the doctrine of nonresistance to evil. I had the privilege of studying your writings also, which left a deep impression on my mind. British Indians, before whom the position was fully explained, accepted the advice that we should not submit to the legislation, but that we should suffer imprisonment, or whatever other penalties the law may impose for its breach. The result has been that nearly one-half of the Indian population, that was unable to stand the head of the struggle, to suffer the hardships of imprisonment, have withdrawn from the Transvaal rather than submit to [the] law which they have considered degrading. Of the other half, nearly 2.500 have for conscience's sake allowed themselves to be imprisoned, some as many as five times. The imprisonments have varied from four days to six months, in the majority of cases with hard labour. 
Many have been financially ruined. At present there are over a hundred passive resisters in the Transvaal gaols. Some of these have been very poor men, earning their livelihood from day to day. The result has been that their wives and children have had to be supported out of public contributions, also largely raised from passive resisters. This has put a severe strain upon British Indians, but, in my opinion, they have risen to the occasion. The struggle still continues and one does not know when the end will come. This, however, some of us at least have seen most clearly, that passive resistance will and can succeed where brute force must fail. We also notice that, in so far as the struggle has been prolonged, it has been due largely to our weakness and, hence, to a belief having been engendered in the mind of the Government that we would not be able to stand continued suffering.

Together with a friend, I have come here to see the Imperial authorities and to place before them the position, with a view to seeking redress. Passive resisters have recognized that they should have nothing to do with pleading with the Government, but the deputation has come at the instance of the weaker members of the community, and it therefore represents their weakness rather than their strength.

But, in the course of my observations here, I have felt that if a general competition for an eassy on the Ethics and Efficacy of Passive Resistance were invited, it would popularize the movement and make people think. A friend has raised the question of morality in connexion with the proposed competition. He thinks that such an invitation would be inconsistent with the true spirit of passive resistance and that it would amount to buying opinion. May I ask you to favour me with your opinion on the subject of morality? And if you consider that there is nothing wrong in inviting contributions, I would ask you also to give me the names of those whom I should specially approach to write upon the subject.

There is one thing more with reference to which I would trespass upon your time. A copy of your letter addressed to a Hindu on the present unrest in India has been placed in my hands by a friend. On the face of it, it appears to represent your views. It is the intention of my friend, at his own expense, to have 20.000 copies printed and distributed and to have it translated also. We have, however, not been able to secure the original, and we do not feel justified in printing it, unless we are sure of the accuracy of the copy and of the fact that it is your letter. I venture to enclose herewith a copy of the copy, and should esteem it a favour if you kindly let me know whether it is your letter, whether it is an accurate copy and whether you approve of its 
publication in the above manner. If you will add anything further to the letter, please do so. I would also venture to make a suggestion. In the concluding paragraph you seem to dissuade the reader from a belief in reincarnation. I do not know whether (if it is not impertinent on my part to mention this) you have specially studied the question. Reincarnation or transmigration is a cherished belief with millions in India, indeed, in China also. With many, one might almost say, it is a matter of experience, no longer a matter of academic acceptance. It explains reasonably the many mysteries of life. With some of the passive resisters who have gone through the gaols of the Transvaal, it has been their solace. My object in writing this is not to convince you of the truth of the doctrine, but to ask you if you will please remove the word "reincarnation" from the other things you have dissuaded your reader from. In the letter in question, you have quoted largely from Krishna and given reference to passages. I should thank you to give me the title of the book from which the quotations have made.

I have wearied you with this letter. I am aware that those who honour you and endeavour to follow you have no right to trespass upon your time, but it is rather their duty to refrain from giving you trouble, so far as possible, I have, however, who am an utter stranger to you, taken the liberty of addressing this communication in the interests of truth, and in order to have your advice on problems the solution of which you have your life-work.

With respects,

I remain, etc.,

M. K. Gandhi

\section{$\underline{\text { Tradução }}$}

Londres,

1 de outubro de 1909.

Senhor,

permita-me chamar a sua atenção para os acontecimentos que ocorrem no Transvaal (África do Sul) há, praticamente, três anos. 
Nessa colônia há uma população de indianos britânicos constituída por cerca de 13.000 pessoas. Durante vários anos, esses indianos trabalharam em diversas condições ilegais. O preconceito contra a cor e, de certo modo, contra os asiáticos é intenso nessa colônia. No caso dos asiáticos, isso tem ocorrido, principalmente, devido à concorrência comercial. O ponto culminante deu-se há três anos com uma lei, considerada degradante por mim e por várias outras pessoas, especialmente criada para atacar aqueles a quem ela aplicava-se. Em minha opinião, a submissão a uma lei dessa natureza não condizia com o espírito da verdadeira religião. Alguns amigos e eu ainda acreditamos firmemente na doutrina da não-resistência ao mal. Tive o privilégio de estudar também os seus escritos, que deixaram profunda impressão em meu espírito. Os indianos britânicos, a quem a situação fora totalmente explicada, aceitaram o conselho de que poderíamos ser presos ou sofrer quaisquer outras penalidades que a lei nos impusesse. O resultado foi que cerca da metade da população indiana, incapaz de resistir à luta, incapaz de suportar os rigores da prisão, preferiu deixar o Transvaal ao invés de se submeter a essa lei, por ela considerada degradante. Da outra metade, cerca de 2.500 pessoas, deixou-se ser presa por uma questão de consciência, algumas delas até mesmo cinco vezes. As penas têm variado de quatro dias a seis meses e, na maior parte dos casos, com trabalhos forçados. Muitos ficaram financeiramente arruinados. Atualmente há mais de cem resistentes passivos nas prisões do Transvaal. Alguns deles são homens muito pobres, que ganham hoje para comer amanhã. $\mathrm{O}$ resultado é que suas mulheres e filhos tiveram de ser mantidos por contribuições públicas arrecadadas por resistentes passivos. Isso pesou muito sobre os indianos britânicos mas, em minha opinião, eles corresponderam ao que lhes foi pedido. A luta ainda continua e não se sabe quando ela chegará ao fim. No entanto, ao menos alguns de nós perceberam com mais clareza que a resistência passiva vai e pode vencer lá, onde a força brutal certamente falhará. Nós percebemos igualmente que o fato de essa luta ter se prolongado deveu-se à nossa fraqueza e, portanto, à crença, por parte do governo, de que nós não seríamos capazes de resistir a sofrimentos constantes.

Vim a Londres, na companhia de um amigo, para ver as autoridades imperiais e para lhes expor a posição, na intenção de solucionar o impasse. Os resistentes passivos reconhecem a inutilidade de se fazer solicitações junto ao governo, mas a delegação foi constituída pelos membros mais fracos da comunidade; portanto, ela representa mais a sua fraqueza do que a sua força. 
No entanto, por aquilo que pude observar aqui, percebi que, se uma subscrição dos temas "ética" e "eficácia" da resistência passiva fosse criada, ela poderia popularizar o movimento e levar as pessoas a pensar. Um amigo levantou a questão sobre moralidade em relação a tal subscrição. Ele acredita que um convite como esse contrariaria o verdadeiro espírito de resistência passiva e poderia levar a crer que seu objetivo é condicionar a opinião pública. Eu gostaria de lhe pedir o favor de me agraciar com a sua opinião sobre esse assunto. E, caso o senhor considere que nada há de errado em fazermos uma subscrição, eu gostaria também de lhe pedir nomes de pessoas a quem eu pudesse me endereçar especialmente para tratar desse assunto.

Há ainda uma coisa a mais em relação a esse mesmo assunto que me faz abusar de seu tempo. Uma cópia de sua carta endereçada a um hindu, sobre a atual agitação na Índia, foi-me entregue por um amigo. À primeira vista, ela parece-me exprimir suas convicções. Meu amigo tem a intenção de, com seus próprios meios, traduzi-la, imprimi-la em 20.000 cópias, e distribuí-la. Nós, no entanto, não podemos obter o original, e não julgamos correto imprimi-la sem estarmos seguros da exatidão do texto; seria grande gentileza de sua parte se o senhor pudesse me dizer se a carta é sua, se a cópia é exata e se o senhor aprova a sua publicação nos temos que lhe expus. Se o senhor desejar acrescentar qualquer coisa que seja à carta, faça-o, por favor. Eu ainda gostaria de me permitir fazer uma sugestão. Ao concluir, o senhor parece dissuadir o leitor da crença na reencarnação. Não sei (caso não seja impertinência minha mencionar isso) se o senhor teve a oportunidade de ter estudado especialmente essa questão. Reencarnação, ou transmigração, é uma crença bastante cara a milhões de pessoas tanto na Índia como também na China. Creio que podemos dizer que, para muitos, trata-se de uma questão de experiência, e não mais uma questão de aceitação acadêmica. A reencarnação explica, de maneira razoável, os vários mistérios da vida. Para muitos resistentes passivos que estiveram nas cadeias do Transvaal, ela foi o seu conforto. Meu objetivo, ao lhe escrever sobre isso, não é o de convencê-lo da verdade da doutrina, mas sim o de lhe perguntar se o senhor poderia suprimir a palavra "reencarnação" das outras ideias das quais o senhor dissuadiu o leitor. Na carta em questão, o senhor citou Krishna muitíssimas vezes e [remeteu o leitor] a certas passagens [do texto]. Eu ficar-lhe-ia grato se o senhor fornecesse-me o título do livro do qual as citações foram extraídas.

Importunei-o com esta carta. Tenho a consciência de que aqueles que the honram e empenham-se em segui-lo não têm o direito de abusar de seu tempo, ao 
contrário, eles têm o dever de, sempre que possível, evitar importuná-lo; no entanto, eu, que sou um estranho para o senhor, tomei a liberdade de lhe endereçar essa mensagem no interesse da verdade, e com a finalidade de receber o seu conselho quanto a problemas cuja solução tem sido o objetivo do trabalho de toda a sua vida.

Com respeito,

Seu sempre

K.M. Gandhi

\section{$\underline{\text { Resposta de Tolstói a Gandhi }}$}

Сейчас получил ваше в вышей степени и интересное и доставившее мне большую радость письмо. Помогай Бог нашим дорогим братьям и сотрудникам в Трансваале. Та же борьба мягкого против жесткого, смирения и любви против гордости и насилия с каждым годом все более и более проявляется и у нас, в особенности в одном из самых резких столкновений закона религиозного с законом мирским - в отказах от военной службы. Отказы становятся все чаще и чаще.

Письмо к индус3 писано мною. Перевод очень хорош. Заглавие книги о Кришне вам будет выслано из Москвы.

Слово reincarnation мне бы не хотелось исключать, потому что, по моему мнению, вера в reincarnation никогда не может быть так тверда, как вера в неумираемость души и в справедливость и любовь Бога. Впрочем, делайте, как хотите. Переведу на индусский язык моего письма и распространению его могу только радоваться.

Думаю, что competition, т.е. денежное поощрение, в деле религиозном неуместно. Если я могу служить чем вашему изданию, то буду очень рад.

Братски приветствую вас и радуюсь общению с вами.

7 окт. 1909 


\section{$\underline{\text { Tradução }}$}

7 de outubro de 1909

Acabei de receber sua interessantíssima carta que me proporcionou grande alegria. Que Deus ajude aos nossos queridos irmãos e colaboradores no Transval. Todos os anos vemos, cada vez mais, crescer aqui a manifestação desta mesma luta: da doçura contra a brutalidade, da humildade e do amor contra a arrogância e a violência; luta que cresce particularmente na forma de um dos mais intensos conflitos entre a lei religiosa e a lei civil: o serviço militar. Tais recusas tornam-se mais e mais frequentes.

A “Carta a um hindu” foi escrita por mim. A tradução está muito boa. O título do livro sobre Krishna ser-lhe-á enviado de Moscou.

Prefiro não excluir o termo reincarnation (1) porque, em minha opinião, a fé na reincarnation (2) nunca poderá ser tão firme quanto a fé na imortalidade da alma e na justiça e amor de Deus. No entanto, faça como achar melhor. A tradução de minha carta para a língua indiana, bem como sua difusão, nada mais me trarão além de alegria.

Creio que competition (3), ou seja, remuneração em dinheiro, é algo descabido quando se trata de uma causa religiosa. Ficarei muito satisfeito se puder colaborar com a sua publicação.

Saúdo-o fraternalmente e fico feliz em manter contato com o senhor.
(1) em inglês no original. (N.T.)
(2) em inglês no original. (N.T.)
(3) em inglês no original. (N.T.) 


\section{$\underline{\text { Segunda carta escrita por Gandhi e endereçada a Tolstói }}$}

London,

November 10, 1909

Dear Sir,

I beg to tender my thanks for your registered letter in connection with the letter addressed to a Hindu, and with the matters that I dealt with in my letter to you.

Having heard about your failing health I refrained, in order to save you the trouble, from sending an acknowledgment, knowing that a written expression of my thanks was a superfluous formality; but Mr. Aylmer Maude, whom I have now been able to meet reassured me that you were keeping very good health indeed and that unfailingly and regularly you attended to your correspondence every morning. It was a very gladsome news to me, and it encourages me to write to you further about maters which are, I know, of the greatest importance according to your teaching.

I beg to send you herewith a copy of a book written by a friend - an Englishman, who I at present in South Africa, in connection with my life, in so far as it has a bearing on the struggle with which I am so connected, and to which my life is dedicated. As I am very anxious to engage your active interest and sympathy, I thought that it would not be considered by you as out of the way for me to send you the book.

In my opinion, this struggle of the Indians in the Transvaal is the greatest of modern times, inasmuch as it has been idealized both as to the goal as also the methods adopted to reach the goal. I am not aware of a struggle in which the participators are not to derive any personal advantage at the end of it, and in which 50 per cent of the persons affected have undergone great suffering and trial for the sake of a principle. It has not been possible for me to advertise the struggle as much as I should like. You command, possibly, the widest public today. If you are satisfied as to the facts you will find set forth in Mr. Doke's book, and if you consider that the conclusions I have arrived at are justified by the facts, may I ask you to use your influence in any manner you think fit to popularize the movement? If it succeeds, it will be not only a triumph of religion, love and truth over irreligion, hatred and falsehood, but it is highly likely to serve as an example to the millions in India and to 
people in other parts of the world, who may be down-trodden and will certainly go a great way towards breaking up the party of violence, at least in India. If we hold out to the end, as I think you would, I entertain not the slightest doubt as to its ultimate success; and your encouragement in the way suggested by you can only strengthen us in out resolve.

The negotiations that are going on for a settlement of the question have practically fallen through, and together with my colleague I return to South Africa this week, and invite imprisonment. I may add that my son has happily joined me in the struggle and is now undergoing imprisonment with hard labour for six months. This is his fourth imprisonment in the course of the struggle.

If you would be so good as to reply to this letter, may I ask you to address your reply to me at Johannesburg, S.A., Box 6522.

Hoping that this will find you in good health.

I remain, etc.,

M. K. Gandhi

Obs.: Doente, Tolstói jamais respondeu a essa carta.

\section{$\underline{\text { Tradução }}$}

Londres,

10 de novembro de 1909.

Prezado senhor,

peço-lhe que aceite meus agradecimentos por sua correspondência registrada, relativa à carta endereçada a um hindu, bem como às questões tratadas na carta que enderecei ao senhor.

Eu soube de sua debilitada saúde e, para lhe evitar o incômodo de uma resposta, limitar-me-ei a acusar o recebimento, sabendo que uma carta escrita, expressando os meus agradecimentos, não passaria de simples formalidade supérflua; mas Aylmer Maude, com quem pude me encontrar, assegurou-me que o senhor estava 
em boa saúde e que, regular e infalivelmente, cuidava, todas as manhãs, de sua correspondência. Foi uma grata notícia para mim, e ela encoraja-me a lhe escrever mais detalhadamente sobre problemas que são, eu reconheço, da maior importância em função de seus ensinamentos.

Peço-lhe que aceite o exemplar adjunto de um livro escrito por um amigo, um inglês que, atualmente, encontra-se na África do Sul. Este livro está relacionado à minha vida, na medida em que ele apóia a luta na qual estou tão envolvido e a qual dediquei minha vida inteira. Como estou muito ansioso para despertar seu interesse e simpatia, creio que o senhor não consideraria um gesto inoportuno de minha parte enviar-lhe este livro.

Em minha opinião, essa luta dos indianos no Transvaal é a maior dos tempos modernos, visto que ela foi idealizada visando-se tanto o objetivo como os métodos empregados para alcançá-lo. Não conheço luta em que, ao final, os participantes não tirem algum proveito pessoal, e em que 50\% das pessoas nela envolvidas tenham passado por grandes sofrimentos e provações em nome de algum princípio. Não me foi possível divulgar essa luta tanto quanto eu gostaria. Hoje o senhor atinge, possivelmente, o mais numeroso público. Se o senhor ficar satisfeito com os fatos tratados pelo senhor Doke em seu livro, e se o senhor considerar que as conclusões às quais cheguei são justificadas pelos fatos, posso lhe pedir que use a sua influência da maneira, seja ela qual for, que o senhor julgar adequada para popularizar o movimento? Se obtivermos sucesso, esse movimento não será apenas o triunfo da religião, do amor e da verdade sobre a falta de religião, o ódio e a falsidade, mas é muito provável que [essa vitória] sirva de exemplo a milhões [de pessoas] que possam ter sido espezinhadas na Índia e em outras partes do mundo. Certamente ela será um bom meio para quebrar o partido da violência, ao menos na Índia. Se nós resistirmos até o fim, e tenho a certeza de que o senhor irá fazê-lo, não tenho a menor dúvida a respeito do sucesso final; e o seu encorajamento, na forma que o senhor julgar melhor, apenas poderá reforçar a nossa situação.

As negociações que estavam em andamento, sobre a regulamentação dessa questão, praticamente fracassaram e, na companhia de uma amigo, volto para a África do Sul nesta semana, expondo-me à possibilidade de ser preso. Acrescento ainda que meu filho juntou-se calorosamente a mim nesta luta e, agora, está preso, cumprindo pena de seis meses de trabalhos forçados. Esta foi a quarta vez, no decorrer de nossa luta, que ele foi preso. 
Se o senhor tiver a bondade de responder a esta carta, pedir-lhe-ei endereçar a sua resposta para Johannesburg, S.A., Box 6522.

Na esperança de que esta carta encontre-o em boa saúde,

Seu obediente devoto.

M.K. Gandhi.

\section{$\underline{\text { Terceira carta escrita por Gandhi e enviada a Tolstói }}$}

Johannesburg,

Transvaal,

South África,

April 4, 1910

Dear Sir,

You will recollect my having carried on correspondence with you whilst I was temporarily in London. As a humble follower of yours, I send you herewith a booklet which I have written. It is my own translation of a Gujarati writing. Curiously enough, the original writing has been confiscated by the Government of India. I, therefore, hastened the above publication of the translation. I am most anxious not to worry you, but, if your health permits it and if you can find the time to go through the booklet, needless to say I shall value very highly your criticism of the writing. I am sending also a few copies of your Letter to a Hindou, which you authorized me to publish. It has been translated in one of the Indian languages also.

I am,

Your obedient servant,

M. K. Gandhi 


\section{$\underline{\text { Tradução }}$}

Johannesburg,

Transvaal,

África do Sul,

4 de abril de 1910

Prezado senhor,

O senhor estará lembrado de que eu mantive correspondência com o senhor durante minha breve estada em Londres. É como humilde discípulo seu que eu lhe envio junto com esta carta um pequeno livro que escrevi. Trata-se de uma tradução que fiz do original, escrito em gujarati. Curiosamente, o texto original foi confiscado pelo governo indiano. Por esse motivo, apressei-me em publicá-lo nesta tradução. Temo incomodá-lo mas, se a sua saúde permitir, e se o senhor tiver tempo para folhear o livro, inútil seria dizer que eu apreciaria muitíssimo suas críticas sobre o texto. Envio-lhe também algumas cópias de sua Carta a um hindu, que o senhor autorizou-me a publicar. Ela também foi traduzida para uma das línguas da Índia.

Seu humilde servo,

M.K. Gandhi.

\section{$\underline{\text { Resposta de Tolstói a Gandhi }}$}

Yasnaya Polyana

8 th May 1910

Dear friend,

I have just received your letter and your book, Indian Home Rule.

I read your book with great interest because I think the question you treat in it: the passive resistance - is a questiono f the greatest importance, not only for Índia but for the whole humanity. 
I could not find your former lettres, but came across your biography by J. Doss, which tôo interested me much and gave me the possibility to know and understand your letter.

I am not quite well at present and therefore abstain from writing to you all what I have to say about your book and all your work, which I appreciate very much, but I will do it as soon, as I will feel better.

Your friend and brother

Leo Tolstoy

\section{$\underline{\text { Tradução }}$}

Iásnaia Poliana,

8 de maio de 1910

Prezado amigo,

acabei de receber sua carta e seu livro The Indian Home Rule.

Li seu livro com grande interesse porque penso que a questão nele tratada, a resistência passiva, é questão da maior importância não apenas para a Índia, mas para toda a humanidade.

Não pude encontrar suas cartas antigas, mas percorri sua biografia, escrita por J. Doss, que também me interessou muito, e possibilitou-me conhecê-lo e compreendê-lo melhor.

Não me sinto muito bem no momento e, por conseguinte, [também] privado de lhe escrever tudo aquilo que tenho a dizer sobre seu livro e sobre todo o seu trabalho, que muito apreciei; mas farei isso tão logo me sinta melhor.

Seu amigo e irmão,

Lev Tolstói 


\section{Quarta carta escrita por Gandhi e endereçada a Tolstói}

Johannesburg,

August 15, 1910

Dear Sir,

I am much obliged to you for your encouraging and cordial letter of the $8^{\text {th }}$ May last. I very much value your general approval of my booklet, Indian Home Rule. And, if you have the time, I shall look forward to your detailed criticism of the work which you have been so good as to promise in your letter.

Mr. Kallenbach has written to you about Tolstoy Farm. Mr. Kallenbach and I have been friends for many years. I may state that he has gone through most of the experiences that you have so graphically described in your work, My Confessions. No writings have so deeply touched Mr. Kallenbach as yours; and, as a spur to further effort in living up to the idealsheld before the world by you, he has taken the liberty, after consultation with me, of naming his farm after you.

Of his generous action giving the use of the farm for passive resisters, the number of Indian Opinion. I am sending herewith will give you full information.

I should not have burdened you with these details but for the fact of your taking a personal interest in the passive resistance struggle that is going on in the Transvaal.

I remain,

Your faithful servant,

M. K. Gandhi

$\underline{\text { Tradução }}$

Johannesburg,

15 de agosto de 1910 
Prezado senhor,

agradeço-lhe profundamente por sua encorajadora e cordial carta de 8 de maio passado. Aprecio muitíssimo a sua aprovação geral de meu pequeno livro Indian Home Rule. E, se o senhor dispuser de tempo, aguardarei suas críticas detalhadas sobre o trabalho, generosamente prometidas em sua carta.

O senhor Kallenbach escreveu-lhe sobre a Fazenda Tolstói. O senhor Kallenbach e eu somos amigos há muitos anos. Posso lhe afirmar que ele vivenciou a maior parte das experiências que o senhor descreveu de maneira tão pitoresca em seu trabalho Minhas Confissões. Nenhum outro texto tocou tão profundamente o senhor Kallenbach como o seu; e, como um estímulo para um ulterior esforço para viver de acordo com o ideal apresentado ao mundo pelo senhor, ele tomou a liberdade, depois de se consultar comigo, de dar seu nome à fazenda dele.

De seu ato generoso de permitir o uso da fazenda aos resistentes passivos pode ser lido no número de Indian Opinion que estou lhe enviando em adjunto, e onde o senhor encontrará informações mais completas. Eu não o teria sobrecarregado com esses detalhes se não fosse o interesse pessoal que o senhor tem manifestado pela luta pela resistência passiva que se desenrola agora no Transvaal.

Permaneço

Seu humilde servo, M.K. Gandhi

\section{$\underline{\text { Resposta de Tolstói a Gandhi }}$}

Получил ваш журнал Indian Opinion и был рад узнать все то, что там пишется о непротивляющихся. И захотелось сказать вам те мысли, которые вызвали во мне это чтение.

Чем дольше я живу, и в особенности теперь, когда живо чувствую близость смерти, мне хочется сказать другим то, что я так особенно живо чувствую и что, по моему мнению, имеет огромную важность, а именно о том, что называется непротивлением, но что в сущности есть не что иное, как учение любви, не извращенное ложными толкованиями. То, что любовь, т.е. 
стремление душ человеческих к единению, и вытекающая из этого стремления деятельность есть высший и единственный закон жизни человеческой, это в глубине души чувствует и знает каждый человек (как это мы яснее видим на детях), знает, пока он не запутан ложными учениями мира. Закон этот был провозглашен всеми, как индийскими, так и китайскими и еврейскими, греческими, римскими мудрецами мира. Думаю, что он яснее всего был высказан Христом, который даже прямо сказал, что в этом одном весь закон и пророки. Но мало этого, предвидя то извращение, которому подвергается и может подвергнуться этот закон, он прямо указал на ту опасность извращения его, которая свойственна людям, живущим мирскими интересами, а именно ту, чтобы разрешать себе защиту этих интересов силою, т.е., как он сказал, ударами отвечать на удары, силою отнимать назад присвоенные предметы и т.п. и т.п. Он знает, как не может не знать этого каждый разумный человек, что употребление насилия несовместимо с любовью как с основным законом жизни, что, как скоро допускается насилие, в каких бы то ни было случаях, признается недостаточность закона любви и потому отрицается сам закон. Вся христианская, столь блестящая по внешности, цивилизация выросла на этом явном и странном, иногда сознательном, большей частью бессознательном, недоразумении и противоречии.

В сущности, как скоро было допущено противление при любви, так уже не было и не могло быть любви как закона жизни, а не было закона жизни, кроме насилия, т.е. власти сильнейшего. Так 19 веков жило христианское человечество. Правда, во все времена люди руководствовались одним насилием в устройстве своей жизни. Разница жизни христианских народов от всех других только в том, что в христианском мире закон любви был выражен так ясно и определенно, как он не был выражен ни в каком другом религиозном учении, и что люди христианского мира торжественно приняли этот закон и вместе с тем разрешили себе насилие и на насилии построили свою жизнь. И потому вся жизнь христианских народов есть сплошное противоречие между тем, что они исповедуют, и тем, на чем строят свою жизнь: противоречие между любовью, признанной законом жизни, и насилием, признаваемым даже необходимостью в разных видах, как власть правителей, суды и войска, признаваемым и восхваляемым. Противоречие этого все росло вместе с развитием людей христианского мира и в последнее время дошло до последней степени. Вопрос 
теперь стоит очевидно так: одно из двух: или признать то, что мы не признаем никакого религиозно-нравственного учения и руководствуемся в устройстве нашей жизни одной властью сильного, или то, что все наши, насилием собираемые, подати, судебные и полицейские учреждения и, главное, войска должны быть уничтожены.

Нынче весной на экзамене закона божия одного из женских институтов Москвы законо-учитель, а потом и присутствовавший архиерей спрашивали девиц о заповедях и особенно о шестой. На правильный ответ о заповеди архиерей обыкновенно задавал еще вопрос: всегда ли во всех случаях запрещается законом божиим убийство, и несчастные, развращенные своими наставниками девицы должны были отвечать и отвечали, что не всегда, что убийство разрешено на войне и при казнях преступников. Однако, когда одной из несчастных девиц этих (то, что я рассказываю, не выдумка, а факт, переданный мне очевидцем) на ее ответ был задан тот же обычный вопрос: всегда ли греховно убийство? она, волнуясь и краснея, решительно ответила, что всегда, а на все обычные софизмы архиерея отвечала решительным убеждением, что убийство запрещено всегда и что убийство запрещено и в Ветхом завете и запрещено Христом не только убийство, но и всякое зло против брата. И, несмотря на все свое величие и искусство красноречия, архиерей замолчал, и девушка ушла победительницей.

Да, мы можем толковать в наших газетах об успехах авиации, о сложных дипломатических сношениях, о разных клубах, открытиях, союзах всякого рода, так называемых художественных произведениях и замалчивать то, что сказала эта девица; но замалчивать этого нельзя, потому что это чувствует более или менее смутно, но чувствует всякий человек христианского мира. Социализм, коммунизм, анархизм, армия спасения, увеличивающаяся преступность, безработность населения, увеличивающаяся безумная роскошь богатых и нищета бедных, страшно увеличивающееся число самоубийств, все это признаки того внутреннего противоречия, которое должно и не может не быть разрешено. И. Разумеется разрешено в смысле признания закона любви и отрицания всякого насилия. И потому ваша деятельность в Трансваале, как нам кажется на конце света, есть дело самое центральное, самое важное из всех дел, какие делаются теперь в мире и участие в котором неизбежно примут не только народы христианского, но всякого мира. Думаю, что вам приятно будет узнать, 
что у нас в России тоже деятельность эта быстро развивается в форме отказов от военной службы, которых становится с каждым годом все больше и больше. Как ни ничтожно количество и ваших людей, непротивляющихся, и у нас в России число отказывающихся, и те и другие могут смело сказать, что с ними Бог. А Бог могущественнее людей.

В признании христианства, хотя бы и в той извращенной форме, в которой оно исповедуется среди христианских народов, и в признании вмести с этим необходимости войск и вооружения для убийства в самых огромных размерах на войнах, заключается такое явное, вопиющее противоречие, что оно неизбежно должно рано или поздно, вероятно очень рано, обнаружиться и уничтожить или признание христианской религии, которая необходима для поддержания власти, или существование войска и всякого поддерживаемого им насилия, которое для власти не менее необходимо. Противоречие это чувствуется всеми правительствами, как вашим британским, так нашим русским, и из естественного чувства самосохранения преследуется этими правительствами более энергично, как это мы видим в России и как это видно из статей вашего журнала, чем всякая другая антиправительственная деятельность. Правительства знают, в чем их главная опасность, и зорко стерегут в этом вопросе уже не только свои интересы, но вопрос быть или не быть.

С совершенным уважением Leo Tolstoy. 7 сент. 1910 г. Кочеты

\section{$\underline{\text { Tradução }}$}

Kotchety,

7 de setembro de 1910 .

Recebi sua revista Indian Opinion e fiquei feliz em conhecer o que nela escrevem a respeito dos adeptos da teoria da não-violência. Gostaria de expressar os pensamentos que essa leitura despertou em mim.

Quanto mais tempo eu vivo - e principalmente agora que sinto com clareza a aproximação da morte - mais forte torna-se a necessidade de transmitir a outras 
pessoas, sobretudo aquilo que sinto tão profundamente e que, em minha opinião, é de enorme importância, a saber: o que chamam de não-violência nada mais é, em sua essência, do que a doutrina do amor, livre de falsas interpretações. Ora, o amor, ou seja, a aspiração das almas humanas à união, bem como a atividade que provêm dessa aspiração, representam a única e suprema lei da vida humana, e cada pessoa sabe e sente isso no fundo de sua alma (esse fato torna-se mais evidente em crianças); todo ser humano tem conhecimento disso até o momento em que não se confunde com falsos ensinamentos do mundo. Esta lei foi apregoada por todos os sábios da terra: tanto por hindus como por chineses, hebreus, gregos e romanos. Acredito ter sido ela muito claramente expressa por Cristo: ele chegou a dizer exatamente que esta única lei encerra toda a Lei e, inclusive, os profetas. Além disso, Ele previu o aviltamento a que esta Lei está exposta e apontou claramente o perigo de tal aviltamento, comum aos homens que vivem precisamente por interesses mundanos, isto é, apontou o perigo de os seres humanos permitirem a si próprios defender tais interesses pela força, ou, tal como Ele disse, responder com golpe ao golpe, usar de força para recuperar aquilo que the foi tomado, etc., etc. Ele sabia aquilo que qualquer ser racional não pode deixar de saber, que o emprego da violência não é compatível com o amor, lei básica da vida. Enquanto a violência é praticada, sejam quais forem as circunstâncias, admite-se a insuficiência da lei do amor e, por conseguinte, essa mesma lei é negada. Toda a civilização cristã, tão brilhante em sua aparência, desenvolveu-se sobre uma contradição e sobre equívocos demasiadamente óbvios e estranhos, algumas vezes conscientes mas, na maioria dos casos, inconscientes.

Em resumo, quando a resistência foi incorporada ao amor, já não havia - e tampouco poderia haver - amor enquanto lei da vida e, não havendo a lei da vida, nada poderia existir senão a violência, ou seja, o poder do mais forte. A humanidade cristã viveu dessa maneira durante dezenove séculos. É verdade que, durante todos os tempos os homens guiaram-se unicamente pela violência na organização de suas vidas. A diferença entre os povos cristãos e todos os outros reside apenas nisto: no mundo cristão, a lei do amor foi expressa com clareza total e precisão, como nunca antes havia sido expressa em qualquer outro ensinamento religioso, e os homens desse mundo cristão aceitaram solenemente tal lei e, ao mesmo tempo, permitiram a si mesmos o uso da violência, construindo nela as suas vidas. E, por isso, toda a vida dos povos cristãos está em contradição entre aquilo que eles pregam e entre a base de suas vidas: contradição entre o amor, considerado a lei da vida, e entre a violência, 
considerada, até mesmo, como imprescindível em todas as suas diferentes formas, tais como o poder dos governantes, os tribunais, os exércitos, reconhecidos e louvados. Essa contradição continuou crescendo paralelamente ao desenvolvimento do mundo dos cristãos e, ultimamente, atingiu o último grau. Hoje, a questão é, evidentemente, uma das seguintes: ou reconhecer que nós não aceitamos qualquer ensinamento moral-religioso, e que nos norteamos, na construção de nossas vidas, unicamente pelo poder do forte, ou que todos os nossos impostos, violentamente arrecadados, e que todos os órgãos judiciais e policiais e, em princípio, os exércitos, devem ser abolidos.

Agora, na primavera, durante o exame de catecismo em um dos institutos femininos de Moscou, um professor de catecismo e, em seguida, um bispo ali presente interrogaram as moças sobre os Mandamentos, especialmente sobre o sexto. Depois das respostas corretas sobre esse mesmo assunto, o bispo costumava perguntar se o assassinato era sempre proibido pela lei de Deus, não importando as circunstâncias. E, corrompidas por seus mestres, as infelizes moças deviam responder - e respondiam - que nem sempre, que o assassinato era permitido na guerra e para castigar os criminosos. No entanto, após responder, a uma daquelas infelizes moças (e o que relato aqui não é mentira, mas um foto que me foi transmitido por uma testemunha) foi feita a habitual pergunta: o assassinato é sempre um pecado? Emocionada e ruborizada, ela respondeu com firme convicção que "sempre". E, a todos os costumeiros sofismas do bispo, ela respondia com convicção firme que o assassinato é sempre proibido, e que ele havia sido proibido já no Velho Testamento, e também por Cristo, e que, não somente o assassinato, mas todo tipo de mal contra o próximo. E, apesar de toda a sua grandeza e eloquência, o bispo calou-se, e a moça saiu vitoriosa.

Sim, nós podemos falar em nossos jornais sobre os êxitos da aviação, sobre relações diplomáticas complexas, sobre os diversos clubes, descobertas, as mais variadas alianças, bem como sobre, as assim chamadas, obras artísticas e podemos calar sobre o que aquela moça disse. Calar, no entanto, é impossível; qualquer homem do mundo cristão sente isso de maneira vaga, mas o sente. O socialismo, o comunismo, o anarquismo, o Exército da Salvação, o crescimento da criminalidade, o desemprego, o aumento do luxo excessivo dos ricos e a miséria dos pobres, bem como o espantoso crescimento do número de suicídios, tudo isso são sinais de contradição interna, que deve, e não pode deixar de ser resolvida. E, sem dúvida, resolvida no sentido da aceitação da lei do amor e da negação de qualquer violência. 
É por isso que sua atividade no Transvaal, lugar que nos parece localizado nos confins da terra, é um trabalho central, o mais importante dentre todos os já realizados ultimamente no mundo, em que participarão, certamente não apenas os povos cristãos, mas povos do mundo todo. Acredito, ser-lhe-á agradável saber que entre nós, na Rússia, essa atividade também se desenvolve rapidamente sob a forma de recusa ao serviço militar, que aumenta mais e mais a cada ano. Por menor que seja o número dos adeptos da teoria da não-violência, também aqui, na Rússia, poucos ainda recusam o serviço militar e, tanto estes como aqueles podem, corajosamente, dizer que Deus está com eles. E Deus é mais poderoso do que os homens.

$\mathrm{Na}$ aceitação do cristianismo, apesar da forma deturpada pela qual ele é praticado entre os povos cristãos, e na aceitação, ao mesmo tempo, da necessidade dos exércitos e armamento para assassinatos em larga escala nas guerras, existe uma contradição tão óbvia e tão gritante que deve, inevitavelmente, mais cedo ou mais tarde (parece que mais cedo), ser verificada. Essa contradição deve abolir a aceitação de qualquer religião cristã — necessária para apoiar o poder — ou abolir a existência do exército e da violência apoiada pelo exército, ambos igualmente necessários ao poder. Essa contradição é percebida por todos os governos que são guiados pelo instinto de sobrevivência, tanto pelo seu, o britânico, como pelo nosso, o russo. Estes governos perseguem mais energeticamente a contradição do que qualquer outra atividade antigovernamental: observamos isso na Rússia e vemos isso nos artigos da sua revista. Os governos sabem em que reside o maior perigo para eles: em cuidar atentamente nessa questão não apenas de seus próprios interesses, mas também da questão de sua própria existência.

Com toda a minha estima,

Lev Tolstói 


\title{
Lev N. Tolstói e Mohandas K. Gandhi
}

\begin{abstract}
As gerações por vir terão dificuldade em acreditar que um homem como este realmente existiu e caminhou sobre a Terra.

Albert Einstein, sobre Mahatma Gandhi.

Enquanto houver matadouros, haverá campos de guerra. Lev N. Tolstói
\end{abstract}

No começo da década de 1900, enquantoTolstói era alvo de críticas raivosas no Ocidente; enquanto pessoas passavam o tempo a pensar e a escrever frases políticas antianarquistas e pró-anarquistas, valendo-se, para isso, do chamado "tolstoísmo"; enquanto pseudointelectuais decidiam publicar frases ofensivas sobre Tolstói, das quais citarei apenas uma, de um único autor, de nome (ou cognome) Encolpo, dentre outras várias, de outros autores, todas pretensiosas, descabidas, maldosas e ironicamente cruéis:

Um russo, de profissão conde e, por paixão, literato, escrevia romances num sossego fanático, nas suas propriedades de Iásnaia Poliana. Descobriram o sujeito. E, para impressionar, notaram a beleza filosófica de seus livros. O conde, deslumbrado, fez-se filósofo. Disse o eslavo as mais tolas banalidades dos cristianismos vulgarmente dissidentes. Mas todos reconheceram - ou tal disseram da sua genialidade famosa. E espalharam pelo mundo inteiro a glória filosófica do antigo romancista, ignorante por completo em filosofia, de ciência, profano ${ }^{185}$.

Sabemos quem foi Tolstói, mas quem terá sido Encolpo? Enquanto, alguns anos mais tarde, S. Freud instigava os meios intelectuais com suas teorias e descobertas, enquanto isso acontecia, Mohandas Gandhi encontrava a confirmação dos princípios básicos de sua doutrina de ahimsa ${ }^{186}$ e satyagraha ${ }^{187}$ no Sermão da Montanha, cujo texto abriga uma semente da não-violência ${ }^{188}$, bem como nas obras de Lev Tolstói.

Por razões óbvias, não farei aqui sequer um resumo da trajetória de Gandhi, tampouco julgo necessário chamar a atenção para a importância de fatos há tempos comprovados pela história.

\footnotetext{
185 Encolpo. Ateneida, 1903.

${ }^{186}$ Ahimsa: termo sânscrito que significa não-violência. ( $a=$ não ; himsa $=$ dano ou injúria)

187 Satyagraha: do sânscrito agraha, firmeza, constância, e satya, verdade. A expressão foi criada por Gandhi.

188 "Amai aos vossos inimigos, e orai pelos que vos perseguem."
} 
Romain Rolland ${ }^{189}$ conta-nos que, em 1847, aos dezessete anos de idade, Tolstói encontrava-se doente em um hospital de Kazan, e seu vizinho de leito era um lama budista gravemente ferido, de quem Tolstói recebeu as primeiras noções sobre a Lei da Não-Resistência, e da Não-Violência. Em 1909, sessenta e dois anos mais tarde, portanto, o jovem Gandhi recebia do velho, e já muito doente Tolstói, essa mesma luz preciosa.

Tolstói interessava-se também pelo Oriente, desde seu desejo de estudar línguas orientais (árabe e turco) na Universidade de Kazan, até a influência que as filosofias e religiões orientais exerceram sobre ele e, consequentemente, sobre sua obra. Foi, no entanto, na Índia que mais satisfez sua avidez pelo conhecimento.

O hindu Tarak Nath Das foi, em um primeiro momento, totalmente contrário às ideias sobre a não-violência; sua ambição era libertar a Índia pela luta. Mais tarde, porém, tornou-se amigo íntimo e também colaborador de Gandhi. Em 1908, T. Das, então editor de uma revista revolucionária chamada The Free Hindustan, escreve uma carta a Tolstói, em que exprime sua opinião sobre as injustiças impostas pela Inglaterra, a mesma Inglaterra que, na mesma época, nutria-se de outros interesses e escravizava, com crueldade, milhões de hindus. Segundo ele, apenas um movimento violento poderia libertar seu país. Tolstói responde-lhe, escrevendo aquela que ficaria conhecida como Carta a um hindu, e que se tornou um verdadeiro tratado de nãoviolência. Nela, expõe suas teorias sobre a não-violência e sobre o amor, e tenta, igualmente, alertar os hindus sobre a falta que cometiam ao renegar sua antiga sabedoria para abraçar o erro do Ocidente. Tolstói começa sua carta citando um verso do livro sagrado dos Vedas, e termina-a citando Krishna.

Mahatma Gandhi, que já conhecia parte da obra de Tolstói, leu a Carta a um hindu, em uma tradução feita por Tchertkov; depois de lê-la, escreve a Tolstói, pedindo-lhe autorização para imprimir essa mesma carta em 20.000 exemplares de seu jornal Indian Opinion, publicando-a em 1910, pouco tempo antes da morte de Tolstói. Além disso, Gandhi informa-o sobre o que ocorria na África do Sul, sobre seus pensamentos a respeito da resistência passiva, etc. Depois dessa primeira carta de Gandhi, datada de 1 de outubro de 1909, eles mantêm uma correspondência densa, embora breve, interrompida somente com a morte de Tolstói. Consegui reunir quatro cartas de Gandhi para Tolstói: a primeira, escrita em 1 de outubro de 1909; a segunda,

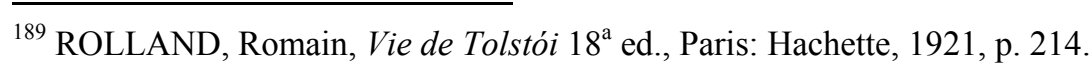


em 11 de novembro de 1909; a terceira, em 4 de abril de 1910; a última, escrita em 15 de agosto de 1910. Além delas, reuni três cartas de Tolstói endereçadas a Gandhi: a última, datada de 7 de setembro de 1910, foi escrita vinte e um dias antes de sua morte; a penúltima foi escrita em 8 de maio de 1910 e, a antepenúltima, data de 7 de outubro de 1909.

Um mahatma russo ou um stáriets hindu? Não importa. Importa-nos o que ambos fizeram. O primeiro achava que o correto era alimentar-se apenas de mingau de aveia, de frutas frescas ou secas, de vegetais e de chá; o segundo acreditava que nada mais lhe era necessário além de frutas, de legumes e do leite cru de uma vaca que sequer lhe pertencia. Um fazia sapatos, o outro fiava. Um tinha uma alma profundamente russa e trajava roupas como as usadas pelos camponeses; o outro, uma alma profundamente indiana e o corpo envolto em um tecido de algodão. Ambos obedeciam a "voz silenciosa do interior", "the still small voice", ou a voz da consciência. Tolstói acreditava que a consciência da cada homem é um verdadeiro bem, pois é dela que Deus se serve para lhe falar. Mística interior e dinâmica exterior pareciam mover esses dois homens.

Além dos Evangelhos, conforme já mencionei, Tolstói formou suas ideias religiosas baseando-se também no budismo e no hinduismo, de modo que percebemos nelas uma espécie de sincretismo religioso, com provável predominância do cristianismo ortodoxo - religião em que fora criado - mas também dos ensinamentos encontrados nos Vedas.

Não poucas vezes identificamos em Tolstói tendência a aproximar os homens de Deus, ou Deus dos homens. Mesmo considerando o ensinamento cristão, que prega a presença de Deus em toda parte, vemos, nas ideias do escritor russo, algo mais absoluto, onipresente e, curiosamente, bem mais simples. Seu Deus está vivo, o que nos remete igualmente à filosofia de Swami Vivekananda (1863-1902), monge, iogue e filósofo hindu que via unicidade tanto no Criador como em sua criação, e para quem a religião era um instrumento de autoconhecimento e autossuperação. Vivekananda também considerava fundamental uma postura fraterna e solidária entre os homens, fosse ela em pensamentos, em sentimentos ou em ações.

Tais observações não reduzem a filosofia religiosa de Tolstói a simples recortes; na verdade, o fato de escolher determinados princípios de determinadas religiões e de, consequentemente, rejeitar outros, já acresce tal escolha de sua personalidade e de ideias próprias sobre a questão. 
Em sua resposta à resolução do Sínodo, por ocasião de sua excomunhão, encontram-se já muitos dos princípios da Teoria da Não-Violência, pois a Igreja é, de fato, violentista e intolerante. O próprio Tolstói diz que, curiosamente, a Igreja não é levada pelo amor e pela tolerância, princípios básicos do Evangelho.

Para Gandhi, Tolstói mostrava o essencial quando se referia, sobretudo, ao cristianismo, mais precisamente aos Evangelhos e ao Sermão da Montanha, textos que, ao lado do Bhagavad Gita, tornar-se-iam sua principal literatura espiritual.

Para ambos, além da não-violência, a prática constante do amor e da fraternidade também era importante, e não podia ser dissociada de um profundo aperfeiçoamento espiritual individual.

Enquanto intelectuais ocidentais discutiam o valor deste ou daquele escritor russo, as ideias de Tolstói eram efetivamente praticadas na África do Sul; mais tarde, essas mesmas ideias ajudariam a libertar cerca de quinhentos milhões de indianos do jugo britânico.

Além disso, de um lado, Gandhi, sob a influência de Tolstói, bem como de sua própria origem indiana, e, de outro lado, Tolstói, sob a influência também do hinduísmo, prezam a simplicidade, o respeito não apenas pelo próximo, mas também pela natureza em geral, daí também o vegetarianismo de Tolstói.

$\mathrm{Na}$ década de 1900, enquanto os ingleses interessavam-se mais pelo indiscutivelmente brilhante Dostoiévski, e menos por Tolstói, cuja filosofia passara a ser por eles considerada "antiintelectual", um indiano magricela, que, algum tempo depois, andaria envolto apenas em um lençol branco, correspondia-se com Tolstói, pedindo-lhe conselhos para salvar da miséria, da fome e da humilhação milhôes de indianos.

Tolstói foi um sábio que, com persistência, esforço próprio, dedicação e seriedade, concluiu, em idade já um tanto avançada, um conjunto precioso de ideias filosóficas, construindo-o peça por peça, tal qual um quebra-cabeça, lentamente, durante o período de quase a totalidade de sua vida. Gandhi, ao contrário, teve a sorte de ler o que Tolstói escrevera e, principalmente, a sorte de ser por ele aconselhado. Embora tenha acrescentado ideias e conceitos próprios à teoria da não-violência, Gandhi recebeu um elaborado trabalho feito por Tolstói e, bem mais jovem do que o escritor russo, aplicou-o de maneira exemplar na África do Sul, em prol de todo um povo. Espero seja essa uma resposta àqueles que, por motivos incompreensíveis, 
comparam os resultados das ações de ambos em prol dos necessitados - sejam as necessidades espirituais, econômicas ou políticas -, e alardeiam que Gandhi foi além.

É natural que, se comparada à atuação de Gandhi, a atuação de Tolstói tenha sido um tanto limitada ou marginal. Ele, na verdade, fez muito pelos servos, fez muito pelos camponeses, fez muito pelos dukhobors, sua cartilha fez muito pela Rússia e ele ainda faz muito àqueles que o leem. $\mathrm{E}$, diferentemente do que se passava com os imigrantes da África do Sul, cuja situação humilhante envolvia importantes países do Ocidente, como a Inglaterra, despertando, por conseguinte, a atenção de boa parte de pessoas de outros países, a Rússia estava distante do mundo, era um tanto nebulosa, e seus problemas eram, sobretudo, internos. A Revolução viria apenas depois da morte de Tolstói.

Infelizmente, Tolstói não pôde ver realizada a prova efetiva da eficácia daquilo em que acreditava, pois morreu quando Gandhi ainda era jovem, e não havia posto totalmente em prática a Teoria da Não-Violência.

Acredito que, provavelmente, Tolstói não tenha tido tempo suficiente para chegar à mesma "síntese" alcançada por Gandhi, ou, talvez, sua dinâmica estivesse mais centrada na escrita do que em atividades totalmente externas, mesmo levando-se em conta o trabalho que ele fez, dentre vários outros, em prol dos camponeses famintos e analfabetos.

É graças a Tolstói que Gandhi separa-se um tanto da grandiosidade da mitologia hindu — de entidades intocáveis, distantes do homem — , abraça o tema cristão de que o homem é feito à imagem de Deus e, à sua vida, acrescenta a figura de Jesus, por exemplo, cujo voto de pobreza tão bem combina com seus ideais espirituais e humanos. Não teria sido o comportamento de Cristo, quando de sua crucificação, um exemplo de não-violência?

Gandhi teve a sorte de se corresponder com um mestre que lhe transmitiu conhecimentos resultantes de toda uma vida; no entanto, homem inteligente e idealista, Gandhi conservou a sua própria personalidade, ou seja, assimilou a filosofia de Tolstói, mas corrigiu, ou melhor, adaptou muitos pontos de vista a seus ideais, não abrindo mão da própria filosofia, das próprias ideias e ideais. Para ele, não havia regras fixas, o que havia eram princípios básicos, ideia que, por estar ausente das igrejas, priva-as de eficácia no desempenho de suas tarefas. 
Certamente, a filosofia "montada" por Tolstói poderia ser lapidada e aperfeiçoada por outro homem dotado, ao menos, das mesmas qualidades, ou seja, inteligência, perspicácia, seriedade, boas intenções, etc. Conforme disse, ele recortou vários elementos de distintas religiões, acresceu-os de suas próprias ideias, costurouos em um único texto, por toda a sua longa vida. Gandhi parece ter feito o mesmo, ao meu ver, e, à situação a que se propôs reparar, à época em que ela se dava, adaptou ao seu material espiritual várias outras fontes: além do que obteve de Tolstói, também ensinamentos extraídos de sua própria visão do hinduísmo, de sua educação mística hindu e também ocidental, da sua experiência de advogado formado por uma universidade europeia, etc. Às descobertas pessoais de Tolstói, Gandhi acrescentou suas próprias descobertas.

Desse material resgatado e/ou elaborado por Tolstói, constam vários preceitos evidentemente inquestionáveis, como o respeito por toda e qualquer forma de vida; são princípios simples e claros, mas o ser humano, em geral, parece não se lembrar deles. Tal sabedoria resultou de experiências pessoais que ele transpôs para sua literatura e também, como é comum em Tolstói, para a própria vida. "Crise” é, em meu entender, sinônimo equivocado de "revelação", ou de compreensão.

Tolstói parece libertar Cristo de qualquer imagem divinizada, simplificando, assim, o cristianismo, e aproximando Cristo e seus ensinamentos dos homens. Gandhi seguiu os mesmos passos, e ambos colocaram, ou tentaram colocar, Cristo na consciência do homem. Entendo que, desse modo, a religião deixa de ser teórica para se tornar prática e aplicável no cotidiano de qualquer homem, de modo que, liberto de imagens icásticas adoráveis, Cristo pode, enfim, acompanhar e orientar cada ser humano.

Além de simplificar a linguagem empregada em sua literatura, Tolstói simplifica também a religião, e liberta igualmente o cristianismo de qualquer possível interpretação tendenciosa, como observamos desde sempre nas várias religiões e na maioria dos ideais políticos que aglomeram pessoas em partidos distintos, ou seja, Tolstói percebe que a verdade, o bem e o amor não estão em um único lugar. Deus e, por conseguinte, bons sentimentos como fraternidade e respeito à vida, dentre outros, ignoram divisões sectárias criadas pelo homem e por seus interesses. Regimes e religiões severos comumente cegam os envolvidos com um véu de maldade, alimentando-os com falsas verdades. Tolstói vê e, eu diria, "prega" o evidente, a 
essência a ser, de fato, considerada, o que realmente vale a pena. Daí, sua admirável coesão e coerência: violência gera violência.

Mais uma vez, eu gostaria de reiterar a congruência admirável de Tolstói: segundo Rousseau, seu primeiro grande mestre, o homem nasce bom, mas é corrompido. Tolstói parece desejar resgatar essa qualidade primitiva do ser humano, já que as religiões, da maneira como são expostas e divulgadas, não o conseguem; para ele, as religiões, depois de depuradas, devem ser, de fato, incorporadas à vida.

Tolstói e Gandhi viveram até idade avançada, gozando de prestígio entre milhões de conterrâneos e não-conterrâneos. Ambos acreditavam que a riqueza não estava naquilo que uma pessoa possui, mas naquilo que ela é. Gandhi fundou um ashram, ou seja, a Colônia Tolstói onde, além de outros trabalhos, revelou-se, a exemplo de Tolstói em Iásnaia Poliana, um exímio educador de crianças e adultos. Para ambos, a verdadeira educação consiste em revelar o melhor de uma pessoa, acreditavam que aprender a ler e a escrever é apenas um dos meios pelos quais é possível educar, e que o mais importante estava na possibilidade de manifestação do melhor que existe no espírito, no coração, na mente e no corpo de uma pessoa.

Em várias ocasiões, Gandhi declarou que aceitava Cristo e seu Evangelho, mas que não aceitava o cristianismo, ou seja, as formas eclesiásticas em que, em geral, o Evangelho de Cristo é compreendido, ensinado e praticado no Ocidente. Para Gandhi, o verdadeiro cristianismo não era uma igreja ou um credo, mas uma vida ética inspirada em experiência mística. Não foi isso também o que nos disse Tolstói em Padre Sérgio e em sua carta dirigida ao Sínodo, bem como em vários de seus contos escritos para o povo? 
CONCLUSÃO 


\section{CONCLUSÃO}

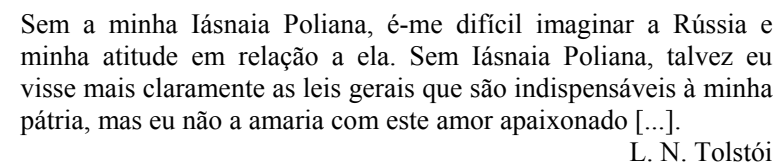

Tolstói e o mundo rural

Lev Tolstói foi um conde, mas um conde que nasceu no campo, e nele viveu sua infância, o que contribuiu para o estreitamento dos laços entre homem e lugar.

Mais tarde, ele abandona os estudos universitários, e, por conseguinte, qualquer perspectiva de seguir a carreira militar ou administrativa, preferindo se transferir para Iásnaia Poliana.

Razões diferentes levaram-no a escolher morar na propriedade em que nascera. Em idade bastante madura, Tolstói tinha sabedoria, uma filosofia própria, convicções sobre inúmeros temas, e a maior parte de sua obra já escrita, mas o jovem Tolstói, aos 19 anos, sentia ter deveres em relação aos camponeses que viviam em sua propriedade, ou seja, uma espécie de obrigação social.

Além das responsabilidades sociais para com os camponeses, a guerra sobretudo a Guerra da Crimeia - e o período vivido no Exército separaram-no ainda mais do meio aristocrático a que pertencia.

Em Iásnaia Poliana, o jovem conde órfão ${ }^{190}$, escritor e proprietário de terras, depara-se, de imediato, com várias características firmemente enraizadas nos servos, traços que levou para várias de suas obras; dentre eles, em muitos casos, a preguiça; em outros, o profundo sentimento de fatalismo e o excesso de conformismo no que diz respeito à vida miserável; muitas vezes, a desonestidade, além da desconfiança sem tamanho em relação ao dono das terras, etc.

Tolstói não era um proprietário como os outros, portanto, certamente não poderia, como era comum na época, usar de violência para castigar, para "corrigir", para impor medo e, assim, gerar produção de trabalho e certa ordem fictícia.

Frente àquele caos moral, espiritual, físico e material, Tolstói sente, fatalmente, o peso de sua impotência, bem como a complexidade do problema. Daí,

\footnotetext{
${ }^{190}$ Sua mãe, a condessa Maria Tolstáia, princesa Volkonski, falecera aos 39 anos de idade, quando Tolstói tinha apenas 2 anos; e seu pai, o conde Nikolai Ilitch Tolstói, aos 42 anos, quando ele tinha 8 anos.
} 
sem dúvida, muito provavelmente pela primeira vez, surge a necessidade imperativa de se aproximar dos camponeses, de ajudá-los conforme o que julgava faltar àquela gente que ele sempre amou.

Não é difícil vermos, já nesse primeiro olhar atento de Tolstói para a vida rural, o início de uma ininterrupta e coerente jornada de vida, marcada, por exemplo, pela necessidade de aproximação verdadeira entre servos e senhor, fato que, seguramente, diminuiria a desconfiança dos camponeses, pois a prática comum, e até então em vigor, defendia que os servos fossem enganados pelos senhores, e por eles castigados, inclusive fisicamente. A escola de Iásnaia Poliana é, então, criada, visto que, sem instrução, base fundamental para a ocorrência de mudanças verdadeiras e profundas, o hiato entre senhor e servo nunca deixaria de existir. Finalmente, anos mais tarde, a vestimenta de mujique no corpo do conde, suas mãos segurando enxada e remexendo a terra, a descoberta da linguagem dos camponeses e, por fim, sua entrega a esse mundo, a essa gente e a seus próprios princípios.

Tolstói vê a dificuldade para se criar uma vida por ele considerada justa, pois as misérias no campo eram muitas e várias. Críticas sociais contundentes são formuladas com seriedade sobre a realidade rural russa da época, realidade que, além dos mais variados vícios, sobretudo de caráter, também apresentava importante diversidade e notável riqueza humana.

Em uma carta datada de 27 de outubro de 1893, endereçada a seu amigo e secretário Vladímir Tchertkov, o escritor diz:

[...] Podemos, e devemos descrever o mujique russo, nosso alimentador e, por que não dizer, nosso mestre, não para dele zombarmos ou para darmos vida à paisagem, mas podemos, e devemos, descrevê-lo dos pés à cabeça, em todo o seu tamanho, não apenas com amor, mas com respeito e até com um estremecimento de veneração.

Tolstói antecipa-se ao consenso geral e à efetiva aplicação do decreto que abole a servidão e libera os servos ${ }^{191}$; antecipa-se também quando compreende que os esforços por parte da sociedade e do governo em alfabetizar o camponês eram infrutíferos, porque aqueles que podiam ensinar não compreendiam que não sabiam o que ensinar nem como ensinar, e que resultados surgiriam apenas quando fosse

${ }^{191}$ Em fevereiro de 1861, Aleksandr II decreta a abolição no país. 
permitido ao camponês indicar o conteúdo do ensinamento de que, realmente, carecia, de acordo com as suas necessidades reais e com a sua curiosidade.

Tolstói observa e trabalha em sua literatura o fato de que senhor e servo codificam a vida de maneiras distintas. Sobre esse assunto, Luba Jurgenson ${ }^{192}$ mostranos que a dificuldade que o senhor de terras sente em se fazer entender por seus servos inverte-se em A Morte de Ivan Ilitch, obra em que o personagem principal, um alto funcionário, é verdade, e não um proprietário de terras mas, de qualquer forma, um homem pertencente a uma "casta" dita mais elevada, é compreendido, ainda que de maneira instintiva, não por pessoas de seu meio, mas exclusivamente por Guerássin, seu criado, um camponês.

Nesse texto, diferentemente sobretudo das pessoas não camponesas e, até mesmo, do próprio Ivan Ilitch, antes do surgimento de sua doença, Guerássin compreende o ciclo natural da vida; embora se compadeça do doente agonizante, o homem simples do campo aceita a morte, destino final, comum e natural de todos.

A religião praticada pelos camponeses, ou seja, a maneira como o mujique compreende e vive o cristianismo ortodoxo, também atraiu a atenção de Tolstói. Em meio à natureza, considerada de maneira ampla — desde o próprio camponês e seus animais até a terra que ele semeia e cuida, para colher e se alimentar do que nela cresce -, a religião parece encontrar mais espaço para existir, para se fazer presente no cotidiano das pessoas. De qualquer maneira, fosse na literatura impressa ou no teatro representado, ao meu ver, Tolstói prestou também uma espécie de "serviço sócio-cultural", pois a Rússia era também os camponeses, que, por sua vez, não correspondiam exatamente à ideia que a sociedade culta fazia deles. Havia igualmente riqueza no miserável mundo camponês, tão distante da nobreza, das universidades, do luxo e da "língua culta" dos centros urbanos.

Além disso, de modo geral, o mujique tinha fé espontânea e sincera no seu dia-a-dia. Todavia, visto que não mais acreditava na Santa Trindade, quanto e com que profundidade Tolstói terá, de fato, conseguido participar dos rituais cristãos ortodoxos junto com os mujiques da região de Tula? Por razões óbvias, era-lhe impossível. As fórmulas que o mujique repetia maquinalmente nas cerimônias eram as mesmas que se repetiam nas igrejas de Moscou, por exemplo. E fórmulas que

\footnotetext{
${ }^{192}$ JURGENSON, Luba. “L'Image du Paysan dans la Mort d'Ivan Ilitch”. In: Tolstói et les Paysans. (Cahiers Léon Tolstoï). Paris: Institut d'Études Slaves, 2006. p.18
} 
chegavam prontas da Igreja não poderiam emocionar Tolstói, nem tampouco interessá-lo.

Interessava-o e emocionava-o, como a sua obra aponta, a originalidade do camponês ao viver a religião, ao rezar à noite antes de dormir, ao pedir proteção, ou cura, para um ente ou para algum animal querido e necessário, ao pedir boa colheita, etc. A sinceridade e a espontaneidade pareciam lhe interessar de fato.

Nas repetições decoradas de parte do ofício religioso estava a instituição, e não a verdade que Tolstói procurava; ele foi um homem crente à sua maneira.

Certo dia, ao ver, entre várias pessoas que cercavam Tolstói, um jovem trajado de determinada maneira, Tatiana Lvovna pergunta ao pai quem era aquele jovem que se destacava dos demais; Tolstói responde-lhe: "É um jovem membro daquela que me é a mais estranha e incompreensível das seitas: a dos tolstoístas." ${ }^{193}$

Vejo, no fato relatado por Tatiana Lvovna, algumas possíveis interpretações. A primeira, talvez mais ao gosto de Maxim Górki ${ }^{194}$, poderia revelar traços "sombrios" de Tolstói, que reforçariam a já espantosa e estupefaciente constatação de que ele sequer acreditava em sua própria filosofia. Há, no entanto, outras razões plausíveis, mais simples e menos tendenciosas, de interpretarmos o relato: Tolstói nunca teve a intenção de criar seita alguma, e, apesar de convicto de suas ideias, talvez, nos últimos anos de vida, tenha vislumbrado a possível quimera que fora o seu sonho. Haveria ainda outra justificativa, bem mais simples do que as anteriores: ele era dotado de grande senso de humor, e a resposta que deu a sua filha pode não ter passado de uma brincadeira. Entendo não haver muitas provas, mas várias teorias, suposições e mais crenças individuais, sejam elas de escritores reconhecidos ou minhas.

Um tema complexo e, por isso mesmo, interessante na obra e na vida de Tolstói é o tema da morte, que foge ao objeto de estudo desta Dissertação. Para um homem como Tolstói, profundamente interessado por tudo, principalmente pelos mistérios da existência e, por conseguinte — ou sobretudo — pela morte, em sua disposição para conhecer o mundo rural russo, talvez possa haver motivos bem mais profundos: por exemplo, a relação simples, aparentemente desprovida de medo, que o camponês mantém com a morte. Em vários textos, o autor insiste nesse tema, o que

\footnotetext{
${ }^{193}$ TOLSTOÏ, Tatiana Lvovna. Avec Léon Tolstö̈, Paris: Albin Michel, 1975, p 221.

${ }^{194}$ GÓRKI, Maxim. Leão Tolstói. (Trad. Rubens Pereira dos Santos). São Paulo: Editora Perspectiva, 1983.
} 
me faz pensar que tenha se dedicado durante muito tempo a compreendê-lo. Em sua inquietude em relação ao assunto, Tolstói concedeu comoventes mortes a vários de seus personagens, fossem eles humanos, animais ou vegetais ${ }^{195}$.

Aliocha, o Pote ${ }^{196}$ é mais um modelo da fé do mundo rural, que parece nascer junto com o mujique, acompanhá-lo durante a vida e ampará-lo no momento final. Aliocha trabalhava muito, era humilde, obediente, e suportava, com resignação, todas as humilhações a que era submetido, toda sorte de privação material que a vida e as pessoas lhe impunham. Ele sequer sabia rezar conforme se aprende na igreja e nos livros sagrados, mas não se importava com isso, porque talvez nem percebesse a sua “falha”, e rezava assim mesmo, com gestos, até. Aliocha ignora qualquer possível barreira entre Deus e si mesmo, pois o natural é que não exista obstáculo algum. Nada, em Aliocha, é premeditado ou calculado, ao contrário, tudo é natural, simples e espontâneo.

A morte de Aliocha comove de fato: ele agradece a Iustina - a cozinheira com quem desejou se casar, mas foi proibido por seu pai e por seu patrão — por sua compaixão, por haver se apiedado dele. Ainda no leito de morte, diz a ela que tudo estava bem; recita, ao lado do pope, suas últimas preces, à sua maneira, com as mãos e com o coração, e, em seu coração, sente a certeza de que, se aqui onde estamos é bom, lá, para onde ele iria, certamente seria igualmente bom. Lembremo-nos de que Aliocha levava uma vida miserável, dificultada mais ainda pela insensatez e pelo desamor alheio. À beira da morte, ele fala pouco, pede apenas água para beber e admira-se com alguma coisa. Assim morre Aliocha: admirado com alguma coisa.

Aliocha aceitou com resignação e respeito sua vida dura, todos os que the causaram mal ou que abusaram dele, de sua condição humilde de simples camponês pobre, de seu caráter dócil e servil, mostrando-nos uma espécie de amor e de fé absolutos. O amor sincero e desinteressado pela vida, pela natureza e pelo semelhante talvez seja a mais forte maneira de manifestação do divino no homem.

Ivan Búnin conta-nos que, em seu leito de morte, em Astápavo, Tolstói disse: "Os mujiques, os mujiques, como eles sabem morrer!" 197 e que, em seguida, pôs-se a chorar.

\footnotetext{
${ }^{195}$ O texto "Três mortes" é um exemplo magnífico.

${ }^{196}$ A tradução deste conto encontra-se no apêndice deste trabalho.

${ }^{197}$ BOUNINE, Ivan. La Délivrance de Tolstói. (Trad. Marc Slonim). Paris: Gallimard, 1939. p. 30.
} 
De acordo com as ideias de Rousseau, que muito influenciou o jovem Tolstói, o Natural identifica-se com o Bem. Tolstói acreditava que a origem do pecado estava no desconhecimento do Bem por parte do pecador, fosse por falta de instrução ou, a rigor, pela maneira incorreta de a sociedade atuar. $\mathrm{O}$ camponês vive intimamente ligado à terra, e a simplicidade parece carregar consigo alguma verdade importante.

Em relação a Tolstói, desconhecemos muitas respostas e nunca as saberemos. Fazemos suposições sobre assuntos que nos perseguem em sua obra, vida e personalidade, e que impulsionam a crítica a escrever um número incontável — por vezes incontrolado - de páginas, embora o limite da curiosidade, mesmo da mais sincera e bem intencionada curiosidade intelectual, deva ser o respeito pelo objeto de estudo.

Tolstói nos disse bastante sobre si, mais do que muitos outros escritores, deixou-nos extensa obra, surpreendentemente autobiográfica, além de espessos volumes de seu próprio diário íntimo.

Mas talvez haja alguma coisa que me tenha escapado, que eu não compreendi? - perguntava-me eu repetidamente. De todas as maneiras, não é possível que esse estado de desespero seja normal para o homem.' E eu procurava uma explicação para as minhas perguntas em todos os conhecimentos que os homens haviam acumulado. Eu procurava longa e dolorosamente, não por mera curiosidade e sem preguiça alguma, mas dolorosamente, obstinadamente, dia e noite, eu procurava tal um homem que, prestes a perecer, procura a sua salvação, e eu não encontrei nada.

Em meu modo de pensar, seu desespero merece o nosso respeito. E os ecos de suas mais profundas lamentações merecem o nosso silêncio. 


\section{Bibliografia}

De Lev N. Tolstói:

ТОЛСТОЙ Л. Н. Собрание сочинений. Том десятый. Повести и рассказы - 1872 1886. Москва: Государственное Издательство художественной литературы, 1963.

ТОЛСТОЙ Л. Н. Азбука - Новая азбука. Москва: Просвещение, 1978.

TOLSTOÏ, Léon N. Anna Karénine. Trad. Sylvie Luneau. Paris: Flammarion, 1988.

TOLSTÓI, Leon. Calendário da Sabedoria. $2^{\mathrm{a}}$ ed. Trad. Barbara Heliodora. Rio de Janeiro: Ediouro, 1999. (Original inglês)

TOLSTÓI, Léon. Conféssion. Quelle est ma Foi? Pensées sur Dieu. Trad. Luba Jurgenson. Paris: Pygmalion Gerard Watelet, 1998.

TOLSTÓI, Lev. Contos da Nova Cartilha - Primeiro Livro de Leitura. $2^{\mathrm{a}}$ ed. Trad. M. Aparecida B. P. Soares. São Paulo: Ateliê Editorial, 2005.

TOLSTOÏ, Léon N. Enfance. Adolescence. Jeuneusse. Trad. Sylvie Luneau. Paris: Gallimard, 1998.

TOLSTÓI, Lev. Histórias de Bulka. Trad. Tatiana Belinky. São Paulo: Editora 34, 2007.

TOLSTOÏ, Léon N. La mort d'Ivan Ilitch - Nouvelles et récits (1851-1885). Trad. M et M. Eristov, Louis Jouserandot, J. W. Bienstock, P. Birioukov, M Tougouchy, Michel Cadot. Paris: Flammarion, 1993.

TOLSTOÏ, Léon N. La sonate à Kreutzer. Trad. Sylvie Luneau. Paris: Livre de Poche, 1958.

TOLSTOÏ, Léon. Le Réveillon du Jeune Tsar. Trad. Georges d'Ostoya et Gustave Masson. Paris: Gallimard, 2005.

TOLSTOÏ, Léon. Les Cossaques. Trad. Pierre Pascal. Paris: Gallimard, 2000. (Folio Classique).

TOLSTOÏ, Léon. Les Quatre Livres de Lecture: 1869-1872 . Trad. Charles Salomon. Paris: Éditions Bossard, 1928.

TOLSTOÏ, Léon. Maître et Serviteur. Trad. Tseytline et Jaubert, Vera Volmane, Michel Cadot, M. Tougouchy. Paris: GF-Flammarion, 1992. 
TOLSTOÏ, Léon. Mikhaïl. Trad. Prince Bojidar Karageorgevitch. Paris: Max Milo Editions, 2000.

TOLSTOI, Leão. Obra completa. Trad. João Gaspar Simões, Natalia Nunes, Oscar Mendes, Milton Amado. Rio de Janeiro: Editora José Aguilar, 1962.

TOLSTOI, León Nikolaievich. Obras completas. Trad. Irene e Laura Andresco. Madrid: Aguilar, 1955.

TOLSTÓI, Lev. O cadáver vivo. Trad. Elena Vássina, Graziela Schneider. São Paulo: Editora Peixoto Neto, 2007. (Col. Os grandes dramaturgos - Vol. 24).

TOLSTÓI, Liev. O diabo e outras histórias. Trad. Beatriz Morabito, Beatriz Ricci, Maira Pinto. São Paulo: Cosac \& Naify, 2000.

TOLSTOÏ, Léon N. Oeuvres Complètes du Comte Léon Tolstoï - Articles Pédagogiques. La Revue "Iásnaia Poliana”. Trad. J. W. Bienstock. Paris: P. - V. Stock, Éditeur, 1905.

TOLSTÓI, Liev. Onde existe amor, Deus aí está. Trad. Vitor E. Selin e Áurea G. T. Vasconcelos. Campinas: Versus, 2001.

TOLSTÓI, Liev. Padre Sérgio. Trad. Beatriz Morabito. São Paulo: Cosac \& Naify, 2001.

TOLSTOÏ, Léon N. Résurrection. Trad. Édouard Beaux. Paris: Éditions Gallimard, 2003.

TOLSTOÏ, Léon. Un Musicien Déchu. Trad. Bernard Kreise. Paris: Mille et Une Nuits, 2000.

Sobre L. N. Tolstói:

AUCOUTURIER, Michel. Tolstoï. Paris: Éditions du Seuil, 1996. (Coll. Ecrivains de Toujours).

BERNARDINI, Aurora F. A Modernidade na Literatura Russa. In: Fundadores da Modernidade. I. Chiampi (org.). São Paulo: Editora Ática, 1991, pp. 159-182.

BOUNINE, Ivan. La Délivrance de Tolstoï. Trad. Marc Slonim. Paris: Gallimard, 1939.

BOYER, Paul. Chez Tolstoï: Entretiens à Iasnaïa Poliana. Paris: Institut d'Études Slaves de L'Université de Paris, 1950.

CAVALLARI, Alberto. La Fuite de Tolstoï. Trad. Jean-Paulo Manganaro et Camille Dumoulié. Paris: Christian Bourgois Éditeur, 1989. (Título original: La Fuga di Tolstoi). 
FILLOUX, Jean-Claude. Tolstoï Pédagogue. Paris: Presses Universitaires de France PUF, 1996.

GÓRKI, Máximo. Leão Tolstói. Trad. Rubens Pereira dos Santos. São Paulo: Perspectiva, 1983. (Título original: Sobranie Sotchinienii)

GOURFINKEL, Nina. Tolstoï sans tolstoïsme. Paris: Editions du Seuil. 1946.

GRUNWALD, Constantin. Société et Civilisation Russes au XIX Siècle. Paris: Éditions du Seuil, 1975. (Col. Histoire).

LAFFITTE, Sophie. Léon Tolstoï et ses contemporains. Paris: Pierre Seghers, éditeur, 1960.

MANN, Thomas. Goethe et Tolstoï. Trad. Alexandre Vialatte. Paris: Éditions Payot, 1999. (Petite Bibliothèque Payot).

MAROGER, Dominique. Les idées pédagogiques de Tolstoï. Lausanne: Editions L'Age d'Homme, 1974.

MASIONIENE, Birute. Levas Tolstojus ir Lietuva. Vilnius: Vaga, 1978.

ROLlAND, Romain. TOLSTOÏ, Léon. Monsieur le Comte. Paris: Éditions Albin Michel, 1978. (Cahires Romain Rolland número 24). Illustres).

. Vie de Tolstoï. 18 a ed. Paris: Hachette, 1921. (Col. Vie des Hommes

TOLSTOÏ, Sophie. Journal Intime: 1862-1900. Trad. Daria Olivier. Paris: Éditions Albin Michel, 1980. (Título original: Dniévniki).

SCHNAIDERMAN, Boris. Encontro com Boris Schnaideman. Florianópolis: Editora Noa Noa, 1986, pp. 1-40. Entrevista concedida a Raúl Antelo, Walter Costa e Cleber Teixeira.

STEINER, George. Tolstoï ou Dostoievski. Trad. Rose Celli. Paris: Éditions 10/18, 2004. (Col. Bibliothèques 10/18).

TOLSTOÏ, Serge. Les Enfants de Tolstoï. Paris: Perrin, 1989.

. Tolstoï et les Tolstoï. Paris: Hermann Éditeurs des Sciences et des Arts, 1980.

TOLSTÓI, Tatiana. Tolstói, meu Pai: Recordações. Trad. Lia Correa Dutra. São Paulo: Nova Fronteira, 1978. (Original francês: Avec Léon Tolstoï).

OPOULSKAÏA, L. (org.) Tolstoï vu par lui-même et ses contemporains. Trad. Myriam Fainbaum. URSS: Éditions du Progrès, 1977.

TROYAT, Henri. Tolstoï. Paris: Arthème Fayard, 1965. 
BERNARDINI, Aurora F. e FERREIRA, Jerusa Pires (org.) Mitopoéticas: da Rússia às Américas. São Paulo: Associação Editorial Humanitas, 2006. (co-org.: Programa de Pós-graduação em Literatura e Cultura Russa - USP e Núcleo Poéticas da Oralidades - PUC-SP).

The Slavic and East European Journal. Madison: The University of Wisconsin Press, 1967. (Vol. XI, Number 1).

VÁRIOS. Le Rayonnement de Tolstoï en Occident. Cahiers Léon Tolstoï, $\mathrm{n}^{\circ}$ 9. Paris: Institut d'Études Slaves, 1995.

Slaves, 1990.

. Tolstoï et le théâtre. Cahiers Léon Tolstoï, $\mathrm{n}^{\circ}$ 4. Paris: Institut d'Études . Tolstoï philosophe et penseur religieux. Cahiers Léon Tolstoï, $\mathrm{n}^{\mathrm{o}} 2$. Institut d' Etudes Slaves, 1985.

. Tolstoï vu par les écrivains russes. Cahiers Léon Tolstoï, $\mathrm{n}^{0} 13$. Institut d'Etudes Slaves, 1998.

Slaves, 1998.

. Les récits de conversion. Cahiers Léon Tolstoï, $\mathrm{n}^{0}$ 12. Institut d'Etudes . Tolstoï et les paysans. Cahiers Léon Tolstoï, $\mathrm{n}^{\mathrm{o}}$ 17, Institut d'Etudes Slaves, 2006 ,

WARNER, Elizabeth. Mythes Russes. Trad. Gabriel Raphaël Veyret. Paris: Éditions du Seuil, 2005. (Título original: Russian Myths - Col. Points. Série Sagesses)

WERTH, Nicolas. La Vie Quotidienne des Paysans Russes de la Révolution à la Collectivisation: 1917-1939. Paris: Hachette, 1984.

ZWEIG, Stefan. Trois Poètes de leur Vie: Stendhal, Casanova, Tolstoï. Trad. Alzir Hella. Paris: Belfond, 1983. (Título original: Drei Dichter Ihres Lebens)

Bibliografia geral:

BACHELARD, Gaston. A Chama de uma Vela. Trad. Glória de Carvalho Lins. Rio de Janeiro: Editora Bertrand Brasil S/A, 1989.

BENJAMIN, Walter. Reflexões sobre a Criança, o Brinquedo e a Educação. Trad. Marcus Vinícius Mazzari. São Paulo: Duas Cidades/Editora 34, 2002. (Título original: Uber Kinder, Jugend und Erziehung)

CHEVAlIER, J. e GHEERBRANT, A. Dictionnaire des Symboles. Paris: Robert Laffont/Júpiter, 1982. 
CONSOLIN DEZOTTI, Maria Celeste (org.). A Tradição da Fábula - De Esopo a La Fontaine. São Paulo: Editora Universidade de Brasília - Imprensa Oficial do Estado de São Paulo, 2003.

DEZOTTI, José Dejalma; GUEDES ALCOFORADO, Maria Letícia; MELLO VARGAS, Maria Valiria A. A Tradição da Fábula: de Esopo a La Fontaine. Brasília: Editora Universidade de Brasília, São Paulo: Imprensa Oficial do Estado de São Paulo, 2003. (Org. Maria Celeste Consolin Dezotti).

ENCICLOPÉDIA Universal da Fábula. São Paulo: Editora das Américas, 1957. vol. $11,12,15$.

LA FONTAINE, Jean de. Fábulas de La Fontaine. Trad. Barão de Paranapiacaba. Rio de Janeiro: Imprensa Nacional, 1886.

MATTOSO CÂMARA JR., Joaquim. História e estrutura da língua portuguesa. $3^{\mathrm{a}}$ ed. Rio de Janeiro: Padrão-Livraria Editora, 1979.

PAZ, Octavio. Traducción: Literatura y Literalidad. $2^{\mathrm{a}}$ ed. Barcelona: Tusquets Editores, 1981. (Col. Cuadernos Marginales 18).

SARTORIUS, Bernard. Igreja Ortodoxa. Trad. Manuel Ferreira da Silva. Lisboa: 1982. (Col. Grandes Religiões do Mundo).

SILVA, Noé. Apontamentos de um tradutor de Tolstói. In: TRADTERM - Revista do Centro Interdepartamental de Tradução e Terminologia FFLCH-USP, 2008. vol. 14.

WELLEK, René; WARREN, Austin. Teoria da Literatura. $3^{\text {a }}$ ed. Trad. José Palla e Carmo. Mira-Sintra-Mem Martins: Publicações Europa-América, 1976. 
APÊNDICE 
APÊNDICE

\section{I}

Aliocha, o Pote

Lev. N. Tolstói 


\section{Aliocha, o Pote}

Lev N. Tolstói

Aliochka ${ }^{198}$ era o mais novo dos irmãos. Apelidaram-no Pote porque, certa vez, sua mãe mandara-o levar um pote de leite à mulher do diácono, mas ele tropeçou e quebrou-o. Sua mãe deu-lhe uma surra e as crianças começaram a provocá-lo, chamando-o de "Aliochka, o Pote". Esse passou a ser o seu apelido.

Aliochka era um menino mirrado, com orelhas de abano (suas orelhas pareciam asas), e com nariz grande. As crianças provocavam-no: "O nariz do Aliochka parece um pau fincado entre duas corcundas". Na aldeia havia uma escola, mas Aliocha não conseguia aprender e tampouco tinha tempo para se educar. Seu irmão mais velho vivia na cidade, na casa de um comerciante, e Aliochka começou a ajudar o pai desde criança. Com apenas seis anos de idade, pastoreava ovelhas e vacas pelos campos com sua pequena irmã e, depois de crescer um pouco, começou a pastorear cavalos dia e noite. A partir dos doze anos, já arava a terra e guiava uma carroça. Faltava-lhe força, mas não the faltava habilidade. Estava sempre alegre. As crianças riam dele, ele calava-se ou ria. Se o pai o repreendia, ele calava-se e escutava. Mal terminavam de repreendê-lo, ele sorria e começava a fazer o trabalho que estivesse à sua frente.

Aliocha tinha dezenove anos de idade quando seu irmão foi recrutado como soldado. E o pai mandou-o para a casa do comerciante, no lugar do irmão, como caseiro. Deram a Aliocha as botas velhas do irmão, uma chapka ${ }^{199}$ do pai e uma podiovka ${ }^{200}$, e levaram-no à cidade. Aliocha mal se continha de felicidade naquela roupinha, mas sua aparência não agradou ao comerciante.

- Eu pensei que você traria um homem de verdade para ocupar o lugar de Semion - disse o comerciante, lançando um olhar para Aliocha. — E você chega aqui com um fedelho desses. Para que ele presta?

- Ele pode fazer tudo: atrelar cavalos, ir para um lado e outro e trabalhar duro. Apenas sua aparência é a de um galho seco, mas ele é forte.

— Se é assim, então, logo veremos.

\footnotetext{
${ }^{198}$ Diminutivo de Aliocha. Aliocha: diminutivo de Aleksei. Aliocha Gorchok era o parvo da aldeia, guardião noturno da propriedade de Iásnaia Poliana. (N.T.)

${ }_{199}$ Típico chapéu russo, usado no inverno. (N.T.)

${ }^{200}$ Casaco típico, usado pelos mujiques. (N.T.)
} 
— E, além de tudo, ele é manso. Dá gosto vê-lo trabalhar.

— Fazer o quê? Que fique, então!

E Aliocha passou a viver naquela casa.

A família do comerciante não era grande: compunha-se de sua mulher, da velha mãe, do filho mais velho - casado, quase sem estudo, e que trabalhava nos negócios do pai —, de um segundo filho, estudado e que, depois de concluir o curso ginasial, fora expulso da universidade e vivia com os pais, e de uma filha mais nova, ainda ginasiana.

No começo, Aliocha não agradou, pois seus hábitos eram grosseiros, vestia-se mal, não tinha bons modos e tratava todos de "você", mas logo foram se acostumando com ele. Aliocha trabalhava ainda melhor do que seu irmão. Era, de fato, manso: mandavam-no fazer tudo, e ele fazia tudo com gosto e rapidez, passando, sem descanso, de um serviço a outro. E assim, a exemplo do que acontecia em sua casa, ali também todos os serviços recaíam sobre ele. Quanto mais fazia, tanto mais tarefas se acumulavam. A patroa, a mãe do patrão, a filha, o filho, o caixeiro, a cozinheira, todos mandavam-no ora para cá ora para lá, obrigando-o a fazer isto e aquilo. Ouviase apenas: “Corra aqui, irmão!", ou: “Aliocha, faça isto! Mas será que você se esqueceu de fazer aquilo? Olhe lá, Aliocha, não se esqueça!’. E Aliocha corria, e fazia, e era cuidadoso, e não se esquecia, e dava conta de tudo e sorria sempre.

Em pouco tempo, as botas que pertenceram a seu irmão ficaram rotas, o patrão ralhou com ele porque ele andava com elas em farrapos e os dedos à mostra, e mandou-o comprar um par novo na feira. Embora as botas fossem novas, e Aliocha estivesse feliz com elas, seus pés continuavam velhos, doíam-lhe à noite devido ao corre-corre, e ele irritava-se com eles. Aliocha temia que seu pai pudesse se aborrecer quando, ao chegar para receber o dinheiro, o comerciante descontasse do salário a quantia gasta nas botas.

No inverno, Aliocha levantava-se antes do amanhecer, rachava lenha, depois varria o quintal, alimentava a vaca, o cavalo, e dava-lhes de beber. Depois, acendia as piétchkas $^{201}$, engraxava as botas, escovava a roupa do patrão, acendia os samovares, limpava-os; depois, ou o caixeiro chamava-o para carregar a mercadoria, ou a cozinheira mandava-o sovar a massa e limpar as caçarolas. Depois, mandavam-no ir à cidade, quer para levar um bilhete, quer para pegar a filha da patroa no ginásio, ou

${ }^{201}$ Típico forno-fogão de tijolos e barro, usado para cozinhar, assar e aquecer a casa. (N.T.) 
para comprar unguento para a velha. "Onde você estava, maldito?" — diziam-lhe ora um, ora outro. "Pra quê? Aliocha é ligeiro. Aliochka! Oh, Aliocha!" E Aliochka corria.

Ele engolia o desjejum, e raramente chegava a tempo para almoçar junto com todos. A cozinheira xingava-o porque ele aparecia sempre por último mas, apesar disso, sentia pena dele e guardava-lhe comida quente para o almoço e para o jantar. Havia muito trabalho, especialmente antes e durante as festas. E Aliocha alegrava-se durante as festas, sobretudo porque, nesses dias, davam-lhe algumas gorjetas que, embora pequenas, e somassem sessenta copeques, eram, enfim, o seu dinheiro. Ele podia gastá-lo como bem desejasse, já que nunca via o seu próprio ordenado. Seu pai chegava, pegava o dinheiro com o comerciante e não parava de xingar Aliocha porque ele havia estragado as botas em pouco tempo.

Quando juntou dois rublos do dinheiro das "gorjetas", comprou, a conselho da cozinheira, uma malha de lã vermelha e, quando a vestia, não conseguia tirar dos lábios o sorriso de prazer.

Aliocha falava pouco; quando falava, era sempre entrecortado e breve. E quando the mandavam fazer alguma coisa, ou perguntavam-lhe se ele podia fazer isto e aquilo, ele sempre respondia sem pensar: "Posso tudo" — e, em seguida, arregaçava as mangas e fazia.

Preces, ele não sabia nenhuma, havia se esquecido das que sua mãe lhe ensinara, no entanto, rezava à sua maneira, de manhã e à noite, persignando-se com as mãos.

Assim, Aliocha viveu um ano e meio. De repente, na segunda metade do segundo ano, deu-se o mais estranho fato de sua vida. Tal fato consistia na surpreendente descoberta de que, além das relações humanas que as pessoas mantêm entre si por necessidade, existem outras relações bem especiais: diferentes daquelas que consistem em limpar botas, carregar compras ou atrelar cavalos. Relações em que uma pessoa simplesmente precisa da outra, desejando servi-la e agradá-la e que, ele próprio, Aliocha, era uma pessoa assim. Ele soube disso pela cozinheira Ustinia. Ustiucha $^{202}$ era órfã, jovem e tão trabalhadeira quanto Aliocha. Ela passara a sentir pena dele e, pela primeira vez, Aliocha compreendeu que ele, que a sua própria pessoa - e não os seus serviços — mas que ele era necessário a outro ser humano.

\footnotetext{
${ }^{202}$ Espécie de mingau (de grãos, legumes ou tubérculos) muito comum nas refeições russas. (N.T.)
} 
Quando sua mãe sentia compaixão por ele, Aliocha sequer percebia, parecia-lhe que assim deveria ser, e que era algo totalmente natural, como se ele próprio se compadecesse de si mesmo. Mas então, Aliocha percebeu de repente que, embora Ustinia fosse-lhe totalmente estranha, ela sentia pena dele, guardava-lhe $k a c h a^{203} \mathrm{com}$ manteiga numa vasilha e, enquanto ele comia, ela olhava-o com o queixo apoiado no braço em mangas arregaçadas. Ele lançava-lhe um olhar, ela sorria, e ele também sorria.

Aquilo era tão novo e estranho que, no começo, Aliocha ficou assustado. Ele sentiu que o incomodaria servir como havia servido até então. Mas, apesar de tudo, estava feliz e, quando via suas calças cerzidas por Ustinia, meneava a cabeça e sorria. Quando trabalhava, ou ia para um lado e outro, lembrava-se sempre de Ustinia e dizia: “Ah, mas essa Ustinia!”. Ustinia ajudava-o quando podia, e ele também a ajudava. Ela contou-lhe sua sina, como ficara órfã, como fora acolhida por uma tia, como a mandaram para a cidade e como o filho do comerciante assediava-a e como ela o pusera em seu devido lugar. Ustinia gostava de falar, e Aliocha escutava-a com prazer. Ele ouvia dizer que, frequentemente, acontecia de os mujiques que vivem nas cidades casarem-se com as cozinheiras. E, certa vez, ela perguntou-lhe quando o casariam. Ele disse que não sabia, e que não queria se casar com nenhuma moça da aldeia.

— Quer dizer que você já tem alguém em vista. — disse ela.

— Sim, eu casaria com você. Será que você casaria?

— É... bobo, bobo... Mas sabe direitinho o que falar — disse ela, batendo-lhe com o pano de prato nas costas. — E por que não casar?

Antes da Quaresma, o velho foi à cidade para receber o dinheiro. A mulher do comerciante ficara sabendo que Aleksei queria se casar com Ustinia, e aquela notícia não lhe agradara.

— Ela vai engravidar e, com uma criança, para que vai servir? — disse ela ao marido.

O comerciante entregou o dinheiro ao pai de Aleksei.

— E então, como é que ele está indo? - perguntou o mujique. — Eu disse que ele é manso.

${ }^{203}$ Diminutivo de Ustinia. (N.T.) 
- É, manso, manso, mas meteu bobagens na cabeça. Inventou de se casar com a cozinheira. Eu não quero manter empregados casados. Isso não me convém.

— Bobo, bobo, mas o que ele inventou? — disse o pai. Não se preocupe. Eu o farei desistir.

Chegando à cozinha, o pai sentou-se ao lado da mesa e ficou à espera do filho. Aliocha, que corria com seus afazeres, voltou ofegante.

— Pensei que você fosse ajuizado. Mas o que você inventou? - disse o pai.

- Eu? Nada.

- Como nada? Você quer se casar. Eu vou casar você quando chegar a hora, e vai ser com a pessoa certa, não com qualquer puta da cidade.

O pai falou durante muito tampo. De pé, Aliocha suspirava. Quando o pai terminou, Aliocha sorriu.

— Eu posso desistir, então.

- Quero ver.

Quando o pai saiu, Aliocha ficou só com Ustinia e contou-lhe (ela ficara parada atrás da porta, escutando enquanto o pai falava com o filho):

— Nosso caso não deu certo. Ouviu? Ele ficou bravo e não permite.

Ustinia pôs o rosto no avental e começou a chorar baixinho.

Aliocha estalou a língua.

- Tenho de obedecer. Não tem jeito, preciso desistir.

À noite, quando a mulher do comerciante mandou Aliocha fechar o postigo, ela perguntou-1he:

— E então, escutou o seu pai, desistiu das suas bobagens?

- Claro que desisti. - Aliocha respondeu, riu, e chorou em seguida.

Desde então, Aliocha não falou mais sobre casamento com Ustinia e continuou a viver como antes.

Na Quaresma, o caixeiro mandou-o retirar a neve do telhado. Ele subiu no telhado, limpou tudo, começou a arrancar os cristais de gelo presos à calha, seus pés deslizaram e ele caiu com a pá nas mãos. Por infelicidade, não caiu sobre a neve, mas sobre a cobertura de ferro da entrada. Ustinia e a filha da patroa correram até ele.

— Machucou-se, Aliocha?

— Não, não me machuquei. Nada.

Ele tentou levantar-se, mas não conseguiu, e sorriu. Levaram-no para o seu quarto. Chamaram um enfermeiro. Ele examinou-o e perguntou-lhe onde lhe doía. 
— Dói tudo, mas não é nada. Só que o patrão vai ficar bravo. É preciso avisar o papai.

Aliocha passou dois dias e duas noites acamado e, na terceira manhã, chamaram o pope.

— Você não vai morrer, vai? — perguntou Ustinia.

— Fazer o quê? Será que vamos viver para sempre? Um dia será preciso, replicou rapidamente Aliocha, como de costume. - Obrigado, Ustiucha, por ter se compadecido de mim. Viu como foi melhor não nos terem permitido casar? Do contrário, como seria? Agora tudo está bem.

Rezou, junto com o pope, apenas com as mãos e com o coração. E, em seu coração, havia o sentimento de que, se aqui é bom para aquele que obedece e não ofende, também lá será bom.

Aliocha falava pouco. Pedia apenas que lhe dessem de beber e, o tempo todo, surpreendia-se com alguma coisa.

E, surpreso com alguma coisa, estirou-se e morreu. 


\section{APÊNDICE}

\section{II}

Com Tolstói, em Iásnaia Poliana

Paul Boyer 


\title{
Com Tolstói, em Iásnaia Poliana
}

Paul Boyer (1864-1949)

\author{
Primeira estada \\ (julho de 1901) \\ Primeiro dia \\ 29 de julho de 1901.
}

Abram o mapa da Rússia, publicado no ano passado pela editora Hachette, o mapa do Atlas Schrader; sigam com o dedo a linha da estrada de ferro Moscou-Kursk e, a alguns quilômetros ao sul de Tula, um pouco a oeste da linha, vocês lerão o nome de uma aldeia desprovida da marca de qualquer fato histórico - nem batalha, nem tratado de paz - o nome de uma pobre e humilde aldeia que sequer tem direito ao título de seló, pois não possui nenhuma igreja.

Nessa aldeia, no entanto, nasceu Lev Tolstói. Foi lá que ele viveu mais da metade de sua vida, foi lá que ele escreveu Guerra e Paz e Anna Karênina; é nela que ele deseja morrer, e é nela que ele quer descansar: na encosta do outeiro que desce em direção ao rio, na orla do pequeno bosque de bétulas que, me parece, ele plantou com suas próprias mãos quando ainda era criança. É por isso que o nome Iásnaia Poliana, Campina Clara, pertence, doravante, à história e à geografia.

Iásnaia Poliana fica apenas a uma légua de Koslov, primeira estação de trem depois de Tula; mas os trens são escassos, e os horários inconvenientes; além disso, sei por experiência própria que, em Koslov, por falta de melhor meio de transporte, as chances de se encontrar ao menos uma simples telega são incertas. Então, em Tula, contratei um cocheiro, um bom homem, condutor de uma carroça, todo orgulhoso da borracha que guarnecia as rodas de seu veículo, e fui conduzido pela grande estrada ou, mais exatamente, pelos caminhos livres que a costeiam pela direita e pela esquerda, pois a particularidade das estradas russas, mesmo daquelas que ostentam o pomposo título de "pavimentadas", é de serem, no verão, de tal modo empoeiradas e irregulares que um cocheiro preocupado com o nosso bem-estar esforçar-se-á sempre para nos poupar delas... 
Fui tomado por uma emoção singular quando cheguei à alameda de bétulas gigantes que, depois da poterna, contornam a lagoa e levam-nos até a casa. Passaramse seis anos desde que estive aqui, há seis anos que vi Lev Nikoláievitch pela última vez. Que mudanças, que estragos a doença tenha, talvez, causado nele? Sei, pois me contaram, que o seu intelecto está intacto, que a sua memória está tão segura como antes, que o seu interesse pelos assuntos do espírito continua tão apaixonado como sempre. Mas, o que restará daquele incomparável vigor físico, daquela robustez que, até os últimos meses, até mesmo as últimas semanas, foram gastos em tantos e tão variados exercícios como equitação, caminhada, natação, patinagem, o bastante para preencher a carreira de qualquer esportista profissional?

Estou no final da alameda das bétulas gigantes; dirijo-me ao terraço que contorna a casa, onde, em dias ensolarados, a família faz suas refeições e, de repente, vejo Tolstói à minha frente. Ele levantou-se da espreguiçadeira em que estava deitado, ele está aqui, de pé, apoiando-se apenas em sua bengala, estende-me a mão e deseja-me alegremente as boas-vindas, apresentando-me, ele próprio, a Maria Lvovna, sua filha que eu ainda não conhecia, a seu genro, o príncipe Obolenski, ao médico que cuida dele desde o começo de sua doença, e que deverá voltar para Moscou na tarde de hoje, totalmente tranquilo.

Lev Nikoláievitch emagreceu; seus traços tornaram-se profundos, as rugas que riscavam sua testa estão mais cavadas; derrotado pelo enfraquecimento dos músculos, seu corpo curvou-se, e seus ombros parecem mais próximos um do outro. Mas o conjunto de sua figura não mudou: seu andar continua ágil, extraordinariamente leve e preciso; suas mãos, em pulsos tão finos, não estão sequer trêmulas; seus olhos, esses "pequenos olhos pálidos, profundos e móveis", continuam a nos olhar com o mesmo olhar direto, sob o espesso emaranhado das sobrancelhas quase brancas; apenas, talvez, a voz, menos cheia, menos segura, traia os setenta e três anos do atleta. Mas, se aceitarmos a ideia de vê-lo como um convalescente, não poderemos, de maneira nenhuma, considerá-lo um idoso. "O que mais nos preocupa - dizia-me a condessa — é que meu marido acredita ser ainda jovem, que ele não queira tomar nenhuma precaução, que ele esteja sempre pronto às piores imprudências". Sófia Andréevna tem razão: Tolstói é surdo às "advertências"; mas talvez isso se dê pelo fato de ele não sentir medo nenhum da morte e, além de tudo, de querer proteger os seus e poupar-se, a si próprio, do aflitivo espetáculo de uma vida que o artifício de múltiplos cuidados prolongaria para além de seus limites normais. Ademais, como todos 
aqueles que dividiram suas vidas em duas partes, uma dedicada aos trabalhos do espírito e outra aos trabalhos do corpo, Tolstói nada pode sentir além do horror instintivo, talvez até mesmo inconsciente, das degradações físicas da velhice. Vocês imaginariam o homem que, mais de uma vez, percorreu a pé a estrada de Moscou a Tula; que descansou das manhãs de leitura, ou de criação, trabalhando o campo de qualquer pobre viúva de sua aldeia; que recebeu, há sessenta anos, suas primeiras aulas de bicicleta - e pelos caminhos russos que os mapas do Touring-Club desaconselhariam até mesmo a Pierre Mille - encerrando-se entre quatro paredes, dosando uma poção ou adoçando um chá? Tolstói é daqueles a quem a morte assoma em pleno vigor físico.

Não tive tempo sequer de lhe perguntar por notícias suas, e ele já me falava da França, dos escritores franceses em evidência, de obras francesas recentemente publicadas. "Enviam-me muitos livros — disse-me ele; talvez aqueles que não se vendam de nenhum jeito. Procuro a obra-prima e não a encontro, absolutamente. Mas nós conversaremos sobre tudo isso com mais calma. O médico, que partirá esta tarde, está me chamando para um último exame. Até logo".

E Tolstói sai com um passo alerta, seguindo os conselhos de seu médico, apesar de tudo, sempre fiel observador de suas receitas.

Duas horas depois, durante o chá. O médico foi-se muito satisfeito com o seu paciente, pois a temperatura do corpo voltara ao normal e os pulsos que, há quinze dias, batiam cento e cinquenta pulsações por minuto, não acusam mais do que oitenta. "Dê-me a sua mão — diz-me Tolstói, brincando — , também quero contar as suas..." E eis que, reportando-se a suas impressões da doença, ele diz docemente. "Viver é bom, mas morrer também é bom. É tão bom quando estamos doentes! Sentimo-nos separados de tudo o que é corporal; vivemos apenas da vida do espírito, da vida da alma. E a morte nada tem de terrível! Um abismo, dizem. Comparação falsa. Quando estamos doentes, parece-nos que descemos uma encosta muito suave que, em determinado ponto, é barrada por uma cortina, fina cortina de tecido leve; deste lado da cortina ainda está a vida; daquele lado, está a morte. E quanto o estado da doença sobressai-se, em valor moral, sobre o estado da saúde! Não me fale sobre essas pessoas que nunca ficaram, que nunca estão doentes! Elas são terríveis, sobretudo as mulheres! Uma mulher — saudável — é um verdadeiro animal feroz!”

A esse repente de seu marido, a condessa expressa um sorriso muito dócil. E, como ela comenta sobre ir ao rio para se banhar no fim daquele dia tão quente, Lev 
Nikoláievitch repreende-a afetuosamente: "Não, Sônia! Esta seria a última das imprudências! Seguramente você ficará resfriada!"

Pergunto a Tolstói se ele leu a Prece de Pascal sobre o bom uso da doença. Ele não se lembra dela. E, rapidamente, manda buscarem o volume em uma das prateleiras da biblioteca, da rica biblioteca de Iásnaia Poliana, cujas primeiras coleções foram reunidas por seu pai, o conde Nikolai. "Meu pai era um grande leitor - contou-me ele - e nunca comprava um livro novo se não tivesse acabado o último que havia adquirido". Tolstói segura nas mãos o volume dos Pensamentos, editado por Didot. Ele mesmo procura a Prece e, depois de encontrá-la, estende o livro a um de nós, que a lê em voz alta. Ele escuta com concentração e sem cansaço aparente, totalmente atento, interrompendo apenas com duas ou três exclamações que ele parecia não poder conter. Terminada a leitura: "Que estranha mistura de excelente e de ruim! E como Pascal calunia-se a si mesmo! Não podia ele resistir a essas fórmulas de Teologia que nos surpreendem sempre que as encontrarmos em seus escritos? Ora, a doença, um sinal da cólera de Deus! E outra vez essas maldições contra os judeus e os pagãos! Não, a doença não é isso! É outra coisa!”

E, enquanto Tolstói pega o volume e folheia-o, detendo-se longamente no conhecido fragmento "Incomodem-se", que ele lê com voz lenta, comenta-o engenhosamente, e aprova-o sem reservas, surge-me a esperança de que o autor de $A$ morte de Ivan Ilitch dê-nos um dia, ele também, a sua "prece para o bom uso da doença".

Primeira estada

Segundo dia

30 de julho de 1901.

Tolstói passeou pela propriedade desde as sete horas da manhã de hoje. Eu o vi passar pelas alamedas, calçando botas, usando um grande chapéu de tecido branco, andando com o seu passo alerta, tão jovial. Ele aprecia esses passeios matinais que, jamais, membro algum de sua família perturba. Depois, pôs-se a trabalhar, perseguindo, com exemplar pontualidade, sua labuta cotidiana. Juntou-se a nós à mesa do almoço apenas à uma hora da tarde. Tolstói assiste à refeição familiar, mas 
não toma parte dela: sua última doença obriga-o a seguir um regime, e ele almoça sozinho.

O que ele escreveu esta manhã? Alguma carta, sem dúvida, e as últimas correções de $O$ Único Meio, nova contribuição ao estudo dos problemas sociais que Vladímir Tchertkov deve imprimir na próxima semana em Londres. Sabê-lo-emos em breve, quando Tolstói levar a seus secretários voluntários as páginas cobertas de sua letra grande e apressada. Com excesso de rasuras, de acréscimos e de remissivas, seus manuscritos são muito difíceis de ler. E é por essa razão que, antes de qualquer pessoa, primeiro sua mulher, depois seus filhos e alguns de seus "discípulos", como o excelente e tão apaixonadamente dedicado Nicolas Gay, filho do pintor, tornaram-se seus primeiros secretários voluntários, copiando, durante as tardes, os "escritos" da manhã. "Não acredito - disse-me a condessa - que qualquer outro casamento de um homem de letras tenha resultado em um trabalho comparável ao nosso. Além da preocupação em alimentar, em cuidar, em educar as crianças (a condessa Tolstáia teve treze filhos), eu copiei à mão todas as grandes obras, e lembro-me de noites em que não terminava essa adorável e interessante tarefa antes de duas ou três horas da manhã”.

A mesa mal havia sido retirada, e todos já se apressavam para o trabalho: o príncipe Obolenski copia uma carta em francês que Lev Nikoláievitch endereça ao abade P... para lhe agradecer o envio de sua recente obra; Maria Lvovna e Nicolas Gay terminam a cópia em três exemplares do manuscrito de $O$ Único Meio, outro voluntário revê a cópia de $O$ Cadáver Vivo, ou, pelo menos, as cenas nela escritas, pois é pouco provável que Tolstói retome e termine algum dia esta alegre e breve comédia da qual se falou muito, sobre a qual os jornais inventaram várias histórias, e cujos papéis eram divididos com antecedência entre os atores do Teatro de Arte, em Moscou. E será sempre assim todas as vezes em que as deploráveis indiscrições revelem o assunto de obras "profanas" ainda não concluídas: falar sobre elas com o autor, pressioná-lo para terminá-las é o mais seguro meio de afastá-lo delas para sempre. Assim, apesar do empenho de cada um em copiar as folhas trazidas, ninguém se arrisca a perguntar se talvez outras não tenham ficado perdidas nas gavetas do escritório...

Tolstói retirou-se para seu quarto. Talvez hoje ele tenha abusado de suas forças. Duas gerações vieram vê-lo, dois velhos amigos do regimento, um deles o neto de um dos condenados de dezembro de 1825. De boa vontade, Tolstói consentiu 
uma entrevista; cordial, afável, interessou-se tanto pelas pequenas como pelas grandes novidades que, assim, lhe chegam de fora, perguntando sobre tudo e sobre todos, não detendo a sua curiosidade sequer pela antecâmara dos ministros. Sua sagaz e cautelosa curiosidade é universal, e ela não se satisfaz com os quatro ou cinco jornais (três, ao menos: o excelente "Gazeta Russa", de Moscou, "Tempo Novo", de São Petersburgo, e um grande diário inglês) com os quais ele a alimenta conscientemente, todos os dias.

À tarde, no chá: "Vamos conversar um pouco sobre a literatura francesa atual — disse-me Tolstói. Eu continuo a não entendê-la. Muito frequentemente, parece-me lhe faltar justamente as qualidades mais propriamente francesas, o calor da convicção, o ardor do raciocínio, a clareza.

Os grandes mestres do século XVIII, Voltaire, Diderot, Rousseau, escreveram tantas páginas fortes, belas, úteis para todos, morais! O que são, ao lado deles, os "filósofos" dos dias de hoje? Sim, eu sei, "magos da juventude"; está certo, eles estão cheios de boas intenções, e tudo o que dizem é, de fato, verdadeiro, mas verdadeiro de uma verdade demasiadamente banal: truísmos que já lemos inúmeras vezes, moral e sociologia para uso dos burgueses; sem contar que eles não possuem o mínimo talento. Realmente, acho mais interessante ler os textos dos socialistas, dos anarquistas, principalmente: podemos, ou não, compartilhar a mesma opinião, mas o que eles dizem tem, ao menos, o mérito de não ter sido dito antes deles.

E os romancistas franceses tampouco me satisfazem mais. De que me servem todas essas historietas de uma senhora que se aborrece, de um senhor que não sabe, ele próprio, se ama ou se não ama? Vocês, os franceses, escrevem romances em demasia! É tão fácil escrever um romance! Seria preciso deixar esse passatempo para os antigos ministros... Falaram-me recentemente de um rapaz muito gentil que, parece-me, toca violoncelo de maneira bastante adequada; e não é que ele teve a audácia de escrever um romance — um romance longo - para uma dessas "modernas" revistas francesas? E esse seu romance é de chorar! Outro, havia começado, há cerca de quinze anos, com dois bons volumes de crítica; mas também quis escrever romances! Será que ele não encontrou ninguém capaz de lhe dizer que aquele não era o seu negócio?"

Ter ou não ter talento, essas palavras retornam com frequência aos lábios de Tolstói. Lembram-se do prefácio que escreveu para a tradução russa das obras de 
Maupassant? De Maupassant, que ele amou a ponto de, ao saber de sua doença, ter pensado em ir vê-lo para amenizar sua inconsolável aflição, o que não impediu um ilustre crítico de falar em um jornal sério (não se trata deste) do "grande romancista tão antipático a Tolstói”. Nesse prefácio, muitos anos anterior a $O$ que é a arte? Tolstói define as condições da obra de arte em literatura, e nomeia apenas três, todas elas essenciais: ter alguma coisa a dizer, que essa "alguma coisa" seja de interesse geral e moral, e por enfim, ter talento, simplesmente.

"Eu gostaria também de lhe falar sobre os poetas franceses. Mas o que lhe dizer? Não entendo mais. Ter tido um Victor Hugo, um Musset, um Lamartine, e entusiasmar-se por esses de agora! Não, não entendo mais, eu não entendo mais!”

E Tolstói retorna aos grandes romancistas franceses do século XIX, a Stendhal, a Balzac, a Flaubert.

"Sim, estes foram verdadeiros mestres. E eu admiro também Zola, o Zola dos primeiros romances, o Zola anterior a Doutor Pascal, Turguiénev tinha-o em alta estima; e ele tinha razão. Gosto menos de Daudet. Os Goncourt? Conheço muito pouco seus romances; mas li o Diário: nunca poderíamos falar bem demais. Veja, no ano passado, na Revue Blanche li um romance muito bom: Mémoires d'une femme de chambre $^{204}$, de Octave Mirbeau. Você diz que o autor é conhecido? Eu não sabia. Sim, seu romance é muito bom e possui um interesse verdadeiramente humano. Lembro-me da primeira falta daquela pobre moça, na Bretanha; a cena é de uma beleza contagiante.

"Mas, que não me venham falar da evolução do romance, que não me digam que Stendhal explica Balzac e que, por sua vez, Balzac explica Flaubert. Tudo isso não passa de invenções de críticos. Gosto bastante dos críticos franceses, e são os únicos que leio; o que não quer dizer que os mais notáveis dentre eles não estejam quarenta anos atrasados em relação a tudo o que diz respeito a questões religiosas ou sociais; mas seus "ensaios" são belamente escritos e leio-os com prazer. Isso não me impede de não compartilhar de suas ideias sobre a sucessão Stendhal-Balzac-Flaubert. Os gênios não precedem uns aos outros: os gênios nascem independentes, sempre.”

Depois, com aquela admirável sinceridade que tanto encanto dá a sua conversa:

\footnotetext{
${ }^{204}$ Diário de uma camareira. (N.T.)
} 
"Ah! Quanto a mim, sei o que devo aos outros; conheço-o e digo-o; aos outros, a dois, principalmente: Rousseau e Stendhal.

"Não foram justos com Rousseau; ignoraram a generosidade de seu pensamento; caluniaram-no de todas as maneiras. Li Rousseau, sim, todos os vinte volumes, inclusive o Dicionário de Música.

"Eu fazia mais do que admirá-lo; rendia-lhe um verdadeiro culto: aos quinze anos de idade, carregava no pescoço um medalhão com o seu retrato, como uma imagem santa... Suas páginas tocam o meu coração; acho que eu poderia tê-las escrito.

Stendhal? Vejo-o apenas como o autor de $A$ Cartuxa de Parma e de $O$ Vermelho e o Negro; eis duas incomparáveis obras-primas. Devo-lhe muito, mais do que a qualquer outro: devo-lhe ter compreendido a guerra. Releia, em $A$ Cartuxa de Parma, o trecho sobre a batalha de Waterloo. Quem, então, antes dele, havia descrito a guerra dessa maneira, ou seja, como ela realmente é? Lembra-se de Fabrice atravessando a batalha sem entender "absolutamente nada" sobre o que estava acontecendo, e de como, agilmente, os hussardos fazem-no passar por cima da garupa de seu cavalo, de seu belo "cavalo de general”? Mais tarde, no Cáucaso, meu irmão que, antes de mim, havia sido oficial confirmou-me a veracidade dessas descrições de Stendhal; ele adorava a guerra, mas não era, absolutamente, desses ingênuos que acreditam na pont d'Arcole ${ }^{205}$. "Isso tudo — dizia-me ele - é pompa! E não existe, absolutamente, pompa na guerra. Pouco tempo depois, na Crimeia, bastou-me olhar para ver com meus próprios olhos. Mas, repito-o, tudo aquilo que sei sobre a guerra devo a meu primeiro mestre, Stendhal."

E assim fala o homem que escreveu Guerra e Paz.

\section{Primeira estada}

Terceiro dia

31 de julho de 1901

\footnotetext{
${ }^{205}$ Batalha do Pont d'Arcole, ocorrida em 1776, entre o exército de Napoleão Bonaparte e o exército austríaco. (N.T.)
} 
Esta manhã, Tolstói prolongou seu passeio mais do que o de costume e, como ele havia se dirigido na direção das estrebarias, perguntávamo-nos ansiosamente se ele não havia mandado selar um cavalo. Como todos já sabem, Tolstói não é um convalescente como qualquer outro...

"Quando você for à aldeia — disse-me ele ontem — entre na casa de Tarass. Sua isbá fica ao lado da isbá de Stiepan, você sabe, o velho Stiepan, cujos dedos congelaram numa noite de inverno; aquele que, depois de beber, voltando da cidade e, já sóbrio, arrancou, ele próprio, com a sua faca, as falanges mortas."

$\mathrm{Eu}$ conhecia Stiepan: visitara-o no primeiro dia de minha chegada, e encontrei-o sentado à soleira da porta, reparando, com suas pobres mãos mutiladas, um par de velhos sapatos de tília. E ele contou-me lentamente sua lamentável história, em pequenas frases curtas, cujas palavras sua boca desdentada pronunciava mal, como se estivesse falando consigo mesmo. "E depois, você sabe, patrão - disse-me ele, concluindo - não me queixo. Eu tinha levantado o cotovelo, você sabe; então, o erro foi meu". O que ele não me contou foi que, por exemplo, nos últimos tempos, voltara a beber e que sua mulher batia-lhe com força.

“Entre, então, na casa de Tarass — disse-me Tolstói. É um bom mujique, disciplinado, sóbrio, e que sabe cuidar da casa. Ele foi meu aluno na escola de Iásnaia. Conheci seu pai, conheci seu avô; e eis que, agora, conheço seus netos.”

Fui até a casa de Tarass. Uma bela isbá de tijolos: no térreo, dois cômodos caiados, espaçosos e limpos; no andar superior, o sótão com uma janela". Atrás, o estábulo, os barracões, os chiqueiros; no fundo do quintal, as colmeias, as setenta colmeias, desde sempre, o orgulho da família Tarass. A família é numerosa: a velha mãe, visivelmente respeitada por todos, e que dá as ordens para a recepção do hóspede; um genro, uma nora, bela e saudável camponesa de vinte anos, de pés descalços, com uma sarafana vermelha, os filhos ainda de pouca idade e, finalmente, três netinhos. Levam o samovar para baixo das grandes árvores do quintal, na frente do colmeial. Tarass, seu genro e a velha mãe sentam-se à mesa; os outros, por respeito, permanecem dentro da casa. E a conversa segue, lenta, séria, sobre o feno que terminam de ceifar, sobre o monopólio da aguardente, sobre o grande forno belga, bem perto dali, e sobre os jovens das aldeias que, atraídos pelo bom salário, ali se metiam ao trabalho de bom grado mas que, infelizmente, como tantos outros, não funciona mais. Perguntei-lhe: "Você tem visto Lev Nikoláievitch desde que ele esteve doente?" 
"Nosso patrão? Sim, vi-o de longe, enquanto ele passeava. Eis um bom patrão, e justo, nem um pouco arrogante! Se tivemos uma escola foi graças a ele. (Tarass ignora as mesquinhas discórdias que a escola de Iásnaia Poliana causou a seu fundador). Sempre dando bons conselhos! Tudo o que ele fala é verdade. Uma vez, nós estávamos trabalhando no campo, com o cachimbo na boca; ele aproximou-se de nós, e disse assim: "Por que vocês fumam? Estão fazendo mal a si mesmos. Vão ficar doentes." E ele tinha razão. Eu, por exemplo, se tusso de manhã, é porque fumo muito, não é? E, então, cada um de nós jogou o cachimbo e prometeu a ele não fumar mais. É, prometemos a ele naquele dia. Mas depois nos esquecemos de nossa promessa. Sabe, é o hábito. Mas o nosso patrão tinha razão; ele sempre tem razão.”

Pergunto a Tarass se ele leu alguns dos escritos de seu patrão. Não, ele não leu nada, nem ele nem a sua família; no entanto, todos são alfabetizados, salvo sua nora. E sua resposta, depois de tantas respostas parecidas que ouvi aqui e ali, permite-me compreender melhor a extrema dificuldade, a quase impossibilidade que existe em fazer penetrar até o povo obscuro das isbás e dos khatas $^{206}$ os simples e encantadores contos que o bom mestre da escola de Iásnaia Poliana compôs em sua intenção. $O$ Primeiro Destilador, Prisioneiro do Cáucaso, Ivan, o Tolo, e tantos delicados contos dispersos nos Quatro Livros Russos de Leitura: não seria também literatura tudo isso?

Algumas horas depois, eu contava a Tolstói sobre a minha visita a seu exaluno e, como eu the falava sobre o prazer que senti ao escutar aquela linguagem pitoresca e saborosa, rica em imagens, e de sintaxe tão segura...

"Sim - replicou ele — esses homens também são mestres. Antigamente, quando eu conversava com eles ou com esses errantes que vão, com o alforje nos ombros, pelos nossos campos, eu anotava cuidadosamente algumas expressões usadas por eles, expressões que eu ouvia pela primeira vez, e que são frequentemente esquecidas pela nossa língua literária moderna, mas que estão sempre presentes na boa e velha terra russa. Eu acabei com os meus blocos de notas para escrever o Poder das Trevas, e é por isso que várias palavras de meu drama precisariam de notas explicativas, mesmo para um leitor russo."

Depois, retomando:

${ }^{206}$ Típicas casas ucranianas, construídas com barro e caiadas de branco. (N.T.) 
"Sim, o espírito da língua vive nesses homens e também nesses velhos escritores da Idade Média russa dos quais você me falou ontem, nos autores, em geral anônimos, das Vidas dos Santos. Consultei bastante as vidas dos santos russos, sobretudo aquelas que constam do Livro de Horas. Ah, em seu quarto mesmo, nas prateleiras do lado esquerdo, você encontrará a minha velha edição do Livro de Horas; abra-a, nela achará anotações manuscritas por mim.”

No dia anterior, efetivamente, parte de nossas conversas girou sobre a literatura russa, particularmente sobre os períodos antigos dessa literatura que é, por comodismo e injustamente, datada apenas a partir de Púchkin. E falamos durante muito tempo sobre as vidas dos santos, não apenas sobre aquelas que não passam de traduções banais do grego, mas sobre as que brotam bem fortes na própria terra em que os seus ingênuos heróis viveram, bem como da Confissão do pope Avvakum, essa obra-prima pela qual Turguenev já havia sido tomado por tão belo entusiasmo quando o texto, proibido pelas autoridades durante dois séculos, foi publicado por Nikolai Tikhonravov.

E, de tudo o que Tolstói dissera-me, ele ressaltava que o que mais estimava nos escritores de seu país, antigos ou modernos, como também nos escritores franceses, é, em primeiro lugar, a sinceridade do pensamento e, em seguida, a sinceridade da expressão.

Sinceridade: é sempre neste ponto que Tolstói insiste, e um dia também poderemos dizer sobre ele: Veritatem dilexit. A mais leve suspeita de falta de sinceridade, mesmo que em matéria de estilo, provoca a sua desconfiança ou sua indignação. Apesar da garantia de autenticidade concedida à obra $O$ Canto do Exército de Igor, por consenso quase unânime entre os mais ilustres filólogos russos, ele considera-a apócrifa - e essa opinião não tem a intenção de desagradar meu sábio mestre, M. Louis Léger -, e se, por um lado, Tolstói obviamente admira o maravilhoso talento de Chtchedrin ${ }^{207}$, ele não o perdoa por ter “inventado expressões", maneiras arbitrárias de falar que, por pertenceram apenas àqueles que as criaram, jazem frequentemente letra morta àquele que as lê.

À noite, a mesa do jantar conta com um conviva a mais, um velho amigo da família, esperado há vários dias, liberal, como se costumava ser nos "anos 60", brilhante caçador e um dos espíritos mais esclarecidos da magistratura russa, o

\footnotetext{
${ }^{207}$ Mikhail Evgráfovitch Chtchedrin (1826-1889). Escritor satírico e democrata revolucionário russo. (N.T.)
} 
presidente D... Tolstói apresenta-nos, um ao outro: "Nosso presidente Magnaud"208, diz ele rindo. Mas um presidente Magnaud, cujo ministro não manteve quinze anos à frente de um tribunal de subprefeitura.

Tolstói diverte-se intensamente com a conversa do presidente D... Ele gosta de interrogá-lo sobre o "caso" de sua prática judiciária, e foi de um de seus relatos que Tolstói tomou emprestado o tema de O Cadáver Vivo.

Leon Nikoláievitch trabalhou bastante hoje: permaneceu longas horas em seu escritório, lendo, tomando notas, reunindo material para uma nova obra (livro ou artigo? Livro, de preferência), uma espécie de filosofia das religiões, cujo título será, creio eu: Da Ideia religiosa ${ }^{209}$. No entanto, não há nenhum traço de cansaço em seu nobre e calmo rosto e, esta noite, ele permanece conosco pela primeira vez até mais tarde.

Tolstói pede-me que eu leia em voz alta algumas páginas de Ruskin ${ }^{210}$, sobre a condição dos trabalhadores da indústria moderna, e, terminada a leitura:

"Acima de tudo, que não esperemos encontrar um remédio para os males de que sofremos no Estado socialista aos moldes alemães. Chegará o tempo em que esse socialismo mostrar-se-á como alguma coisa selvagem, monstruosa. Não verei esse tempo; mas você sim vê-lo-á, espero.

"A maioria dos males provém do desaparecimento momentâneo - no entanto, atualmente total — do sentimento religioso. Digo "momentâneo" porque o sentimento religioso é como uma onda que se ergue e que, depois, desce para se erguer novamente. E, no presente momento, estamos todos submersos nessa onda. Não existe mais ideia religiosa em lugar nenhum, nem na França nem na Inglaterra; na Alemanha, menos ainda do que em qualquer outro lugar. E é por isso que tudo parece ser permitido, qualquer injustiça, qualquer violência: guerra dos boers ${ }^{211}$, guerra na China! Poderíamos comparar nosso estado atual àquele do mundo romano um pouco antes de Augusto estabelecer o culto ao imperador. Na França, vocês lutam contra o clericalismo e, sem dúvida, fizeram bem em reagir; mas a vossa lei sobre as

\footnotetext{
${ }^{208}$ Paul Magnaud (1848-1926). Magistrado francês e presidente do tribunal civil de Château Thierry, na Picardia francesa. Conhecido por sua clemência pelos humildes e pelas mulheres, bem como por audaciosas e irreverentes decisões, o juiz Magnaud recebeu o apelido de O Bom Juiz.

${ }^{209}$ Provavelmente o artigo intitulado "O que é a religião e em que consiste a sua essência". (N.T.)

${ }^{210}$ John Ruskin (1819-1900). Escritor, crítico de arte e crítico social britânico. (N.T.)

${ }^{211}$ Em holandês, o termo significa "camponês" e foi usado para designar os habitantes de origem holandesa, ou francesa, por oposição aos colonos brancos de origem britânica, cujo objetivo era a posse das colônias holandesas da África do Sul. Iniciado em 1899, o conflito terminou em 1902, com a assinatura do Tratado de Vereeniging (Transvaal). (N.T.)
} 
associações é perigosa, pois ela pode levar à violação da liberdade. Na Alemanha, Guilherme II pretende confiscar a ideia de Deus em benifício de Brandeburgo. Lembra-se de seu discurso em Jerusalém? Gott mit uns!... Deus esteja conosco!... Mas por que não também com os outros? E os seus discursos aos recrutas, você os leu?

“Certamente, tempos melhores virão. Visto que nada perdura, nada é imutável — nem na China. E o sentimento religioso não escapa à essa lei: ele é um perpétuo devir..."

Esse "perpétuo devir" do sentimento religioso, da fé, é uma das ideias que Tolstói mais considera: o leitor encontrá-la-á na última página de sua Resposta ao Sínodo.

Como aquelas últimas horas inesquecíveis de minha última tarde em Iásnaia Poliana passaram rápido! Nunca vi Tolstói tão alegre e inspirado.

"Sabe — disse-me ele —, hoje é o primeiro dia em que, depois da publicação do decreto do Sínodo (datado de 20-22 de fevereiro, decreto de excomunhão), não recebi nenhuma carta com ofensas?"

Eu li essas cartas ofensivas: elas são vulgarmente grosseiras, muitas vezes ameaçadores. "Você já viu o diabo? Olhe-se no espelho, e verá a sua cara!" — "Por mais que você faça, nós o pegaremos" - "Conseguiu se livrar da doença, [seu] velho demônio?" Morte aos médicos que o curaram!" Tais são as amenidades que, todas as manhãs, Lev Nikoláievitch encontrava em meio à sua correspondência. De quem elas emanam? Não me surpreenderia se várias delas fossem, como se diz, "inspiradas". Todo aquele que, na Rússia, tem um nome conhecido, seja nas ciências seja nas letras, recebeu a notícia do decreto do Sínodo - desse caso tão excepcional, sem precedentes - por um simples erguer de ombros. Em Moscou, numerosas caricaturas - demasiadamente irreverentes se levarmos em consideração a seriedade daqueles que as desenharam - circulam clandestinamente. E o imperador não acabou de comprar para o museu Alexandre III o último retrato de Tolstói feito por Répin ${ }^{212}$ um quadro, mais do que um retrato - em que o pintor teve a singular ideia de representar seu ilustre modelo descalço, para grande desgosto deste quando soube do fato? Então, cada um se defende como pode. Há apenas um mês, na sessão anual da sociedade de conciliação de Moscou, um tal Vorsuniak, alfaiate que,

\footnotetext{
${ }^{212}$ Iliá Répin (1844-1930). Pintor realista, cuja obra criticava a ordem social da época. (N.T.)
} 
inesperadamente, propôs que se votasse a eliminação do nome do conde Tolstói da lista dos membros de honra da sociedade. A quem convencerão que esse estimável alfaiate tenha redigido, ele próprio, sua moção de ostracismo? Não, nem insultos nem ameaças vêm do povo. Outro dia, em Moscou, o izvoztchik ${ }^{213}$ que me conduzia pela cidade concedeu-me a honra de uma conversa e, para minha grande surpresa, percebi que ele tinha conhecimento da excomunhão de Tolstói. Mas ele explicava-a à sua maneira: "Parece — disse-me ele — que esse conde Tolstói 'servia' ao sínodo; mas não estavam satisfeitos com seu trabalho; e então o mandaram embora. É uma pena.”

De onde quer que venham, as cartas ofensivas afetaram profundamente Tolstói; mas, por mais numerosas que sejam, elas não se equivalem em número às cartas de simpatia que recebeu e que continua recebendo da Rússia, de todos os países da Europa, da Índia, da América, de todos os lugares. E as cartas que chegam de lugares onde "não se pensa como ele" são-lhe particularmente caras.

Havia chegado a hora de eu ir embora, quando ele me estendeu uma página manuscrita.

"Recebi isso hoje — disse-me ele; é um fragmento de Renan, admirável. Não sei quem mo envia. Ele foi postado na França. Vamos, você ainda tem tempo. Leianos isso bem alto."

E eu li o que se segue, textualmente copiado na introdução do segundo volume das Origens do Cristianismo:

"Os banidos de uma Igreja pertencem sempre à elite; eles antecipam-se ao tempo; o herético hoje é o ortodoxo do futuro. O que é, aliás, a excomunhão dos homens? O Pai celeste excomunga apenas os espíritos secos e seus corações mesquinhos. Se o padre recusa-se a nos admitir em seu cemitério, proibamos nossas famílias de reclamar. Deus é quem julga; a terra é uma boa mãe, que não faz diferenças. Ao entrar no lado não abençoado, o cadáver de um homem de bem leva consigo as bênçãos.

\footnotetext{
${ }^{213}$ Em russo no original. Cocheiro. (N.T.)
} 


\title{
Com Tolstói
}

\author{
Segunda estada em Iásnaia Poliana \\ setembro de 1902
}

Segunda estada

Primeiro dia

10 de setembro de 1902 .

Hoje, quarta-feira, 10 de setembro, Tolstói já tem completos setenta e cinco anos. Eu não o via desde o ano passado.

"Sinto-me melhor, muito melhor — disse-me ele esta manhã. Ontem, caminhei cinco verstas $^{214}$ a pé pelas belas florestas do Estado que cortam a estrada principal de Tula. Um pouco de sufocação quando falo ao andar; um pouco de fraqueza nas pernas... Você, por exemplo — acrescentou ele rindo — acha que não envelheceu? Todos nós envelhecemos..."

E, no entanto, apesar de três doenças graves que se sucederam uma depois da outra, a velhice não deixou sua marca naquele físico atlético: se o corpo está mais encurvado, a tez está melhor, mais vivaz, o olhar mais vivo, a expressão do rosto mais alegre, realmente mais jovem; e seu andar permaneceu leve e preciso, rápido, jovial, andar de um homem que, desde a infância, exercitou seus músculos praticando todos os esportes. Na frente de meus olhos tenho uma fotografia tirada naqueles dias: Tolstói está de pé, sem chapéu, com botas, e com as mãos sob seu cinto de couro, em um gesto que lhe é familiar. E a semelhança dessa fotografia sem retoques evoca os retratos de dez anos atrás.

Desde que voltou da Criméia, no final do inverno, Lev Nikoláievitch retomou sua vida de obstinada labuta: levanta-se cedo e, após sua caminhada matinal, bastante breve, tranca-se em seu escritório e escreve; durante essas horas da manhã, período em que ele próprio faz questão de consagrar à leitura ou à correspondência, ninguém o incomoda; ele escreve - feliz com a tarefa que escolheu, dando mais preferência a obras de evangelização social ou polêmicas do que a obras de criação pura, mas, trabalhando nestas últimas para descansar das primeiras. Ele escreve e, cerca das duas

\footnotetext{
${ }^{214}$ Medida itinerária russa, equivalente a 1.067 metros. (N.T.)
} 
ou das três horas da tarde, dirige-se à sala de jantar, seu entusiasmo, seu bom humor e seu apetite revelam a alegria da tarefa cumprida.

Há apenas poucas semanas ele concluiu o Apelo aos Trabalhadores, um texto em linguagem popular sobre as questões econômicas atualmente mais urgentes e em que - disse-me ele — deu forte ênfase à teoria de Henry George ${ }^{215}$ sobre a nacionalização da terra. Ele tem, portanto, direito ao descanso, não é mesmo? E é por isso que agora - enquanto espera que um novo "dever" chame-o - ele dedica-se inteiramente a Hadji-Murad, várias vezes retomado e abandonado, e cujas páginas acrescentam-se a outras até se tornarem um episódio da resistência desesperada dos montanheses do Cáucaso, comandada por Shamyl ${ }^{216}$, uma epopeia militar de grande fôlego.

E é assim que o autor de Os Cossacos descansa...

"Não sei quantos seremos esta noite para o jantar — disse-me a condessa Sofia Andriévna; pedi que colocassem vinte talheres. Sente-se à direita de meu marido: conto um pouco com o senhor para impedi-lo de conversar em demasia. Ele exauriu-se nesses últimos dias; falar muito lhe cansa."

Dois generosos buquês estão sobre a mesa, obras-primas do jardineiro, simétricos, redondos, minuciosamente semelhantes; e o jantar começa, bastante cordial. Todos os filhos estão presente, à exceção de dois: Tatiana Lvovna, impedida de deixar seu marido que se encontra gravemente enfermo, e Lev Lvovitch, que se estabeleceu na Suécia. Um amigo da família, o decano da nobreza de uma província vizinha, orador eloquente e ousado, cujo retumbante discurso sobre a liberdade de consciência, pronunciado no ano passado no Congresso das missões ortodoxas, não impediu sua reeleição. Enfim, alguns discípulos, vindos especialmente de Moscou para saudar o mestre, e que, de acordo com o que Tolstói disse em sua Resposta ao Sínodo, somam, no máximo, uma centena; e, dentre eles, um pianista de grande talento, ex-aluno do conservatório de Moscou, por quem Lev Nikoláievitch mantém forte afeição.

No fim do jantar, a condessa levanta-se e, sem a mínima pompa, com uma voz ligeiramente trêmula de emoção, pronuncia estas muito simples palavras: "Lev, nós

\footnotetext{
${ }^{215}$ Político e economista norte-americano (1839-1897). (N.T.)

${ }^{216}$ Líder caucasiano que, durante cerca de vinte anos, resistiu aos russos nas montanhas do Daguestão. Sua derrota significou a manutenção da soberania russa na região. (N.T.)
} 
todos beberemos à sua saúde." E todos se levantam, aproximam-se do querido grande homem, abraçam-no ou apertam-lhe a mão.

Durante o dia, Serguei, o filho mais velho, o bom e obsequiador, Serioja, o mesmo que levou aos Dukhobors ${ }^{217}$ que emigraram para o Canadá o produto bruto de Ressurreição ${ }^{218}$, havia ido à cidade e voltou trazendo surpresas: biscoitos de anis $\mathrm{e}$ mel, pães de mel (Tula orgulha-se tanto de seus pães de mel quanto de seus samovares), foguetes, rojões, carrosséis giratórios... Depois do chá, os dois filhos mais novos e Sacha, a filha caçula, estouraram um fogo de artifício sobre a grama do campo de tênis.

Esta noite, Lev Nikoláievitch aparenta cansaço; mas não quer deixar transparecer nada. "Sente-se ao piano - diz ao músico — , e toque-nos Chopin." Tolstói escuta, sem pronunciar uma palavra, absorto pelo encanto daquelas melodias tristes ou apaixonadas que ele admira com fervor; depois, quando o pianista termina a "Balada número 4", seus olhos enchem-se de lágrimas: “Ah! Que monstro!”, disse ele; levanta-se bruscamente e vai sentar-se à mesa do vinte ${ }^{219}$, esse temível whist russo cujas complicações desencorajaram mais de um bem intencionado francês...

\section{Segunda estada}

\section{Segundo dia}

21 de setembro de 1902.

Volto a Iásnaia Poliana após ter passado uma semana em uma província vizinha, na casa de um de meus mais queridos amigos russos, Alexandre E..., excelente escritor que, por livre escolha, prefere a vida cômoda e saudável de um gentleman farmer às pequenas mesquinharias dos círculos literários de Petersburgo ou de Moscou.

Lev Nikoláievitch recebe-me com a mão estendida; é hora do jantar, e sentamo-nos à mesa.

\footnotetext{
${ }^{217}$ Seita cristã, de origem russa. Literalmente, "lutadores do espírito". Os dukhobors rejeitavam o governo, os popes, os ícones, além de quaisquer ritos eclesiásticos e a Bíblia, com exceção dos Evangelhos. Eram pacifistas convictos que, no final do século XIX, se exilaram, sobretudo, no Canadá. (N.T.)

${ }^{218}$ Tolstói abdicou dos direitos autorais de Ressurreição para patrocinar a viagem dos dukhobors ao Canadá, e era seu filho mais velho, Serguei, quem tratava diretamente com os pacifistas. (N.T.)

${ }^{219}$ Jogo de cartas bastante popular no século XIX. (N.T.)
} 
"E então? - disse-me ele — como vai o nosso amigo? O que ele está escrevendo? Envelheceu? Envelheceu? Eis uma pergunta que ouvimos frequentemente da boca de Tolstói; em se tratando dele, ela não carrega absolutamente a preocupação egoísta de um homem que, ele próprio, se sente envelhecer, mas preocupação de artista para quem o aspecto exterior das pessoas e das coisas sempre interessou no mais alto grau.

A conversa prossegue, variada, bastante animada. Antes de ontem houve uma consulta com médicos: ficou decidido que Tolstói, neste ano, não iria para a Crimeia, e que passaria o inverno em casa. Lev Nikoláievitch, a quem suas três doenças em nada mudaram o seu tranquilo ceticismo em matéria de medicina, deixa que falem e que façam, indulgente e dócil. Ele parece-me bastante feliz com a permissão que the foi dada para permanecer em casa. Apenas Moscou continua-lhe proibida: em Moscou há demasiadas visitas, demasiadas fadigas.

"Que pena - disse-me ele — que você não tenha visto a minha irmã este ano, aquela que é religiosa. Ela partiu apenas poucos dias antes que você voltasse, para retornar ao seu convento: era o fim de sua licença. Ela continua igual, não mudou. Uma noite, sentou-se ao piano e tocou a quatro mãos com a minha mulher..."

As grandes manobras de Kursk $^{220}$ haviam apenas terminado, e comentamos as últimas notícias sobre o assunto; divertimo-nos com a decisão do grão-príncipe Serguei, governador de Moscou e comandante responsável por um dos exércitos, do exército do Sul, derrotado e - chegam a comentar - capturado como prisioneiro pelo general Kuropátkin, ministro de guerra, comandante responsável pelo exército do Norte. Depois, ainda na parte da manhã, chegou uma carta de um oficial, aliado ou amigo da família e que, justamente, é assessor militar do Estado Maior de um dos exércitos em exercício: "Realmente, não compreendo - disse Tolstói. Eis um rapaz bem nascido, inteligente, rico; e continua no Exército! Daqui a quarenta anos, ele não passará de coronel, será aposentado como general de brigada. Isso é vida? Posso compreender que, por falta de melhor opção, por necessidade, alguém siga essa carreira. Mas, e quando nada lhe força a isso? Atração pelo uniforme, sem dúvida; não se vestem como todos; os guardas na cidade fazem-nos a saudação militar e nos dizem: "Vossa Excelência!" Lembro-me de que uma vez, em Moscou, como eu estava me demorando para me sentar no meu lugar em um vagão de terceira classe, o

${ }^{220}$ Cidade localizada na Rússia Central. (N.T.) 
condutor empurrou-me com certa rudeza, com a ajuda dos punhos e do joelho, como os nossos russos sabem fazer: "Vamos, vá logo, velho, ande mais rápido!" Assegurolhe que, se eu tivesse vestindo uma túnica de coronel, ele teria sido mais gentil!" E Tolstói começou a rir por detrás da barba.

Após o jantar: No inverno passado, eu enviara a Tolstói um belo livro de Albert Métin ${ }^{221}$, Socialisme sans Doctrines; ele agradeceu-me e contou-me o interesse com que o lera. "Nos últimos dias - acrescentou ele - li uma compilação de artigos e de discursos de Jaurès ${ }^{222}$. Há de tudo neles: leis trabalhistas, a questão do açúcar, a Conferência de Haia. Há de tudo, e não há nada. Que admirável orador esse Jaurès deve ser!... O socialismo, veja, é um pouco como a nossa ortodoxia russa: você o espreme, encurrala-o, acredita tê-lo apanhado e, bruscamente, ele vira-se e lhe diz: "Não, não! eu não sou aquele que você pensa; eu sou outro." E escorrega-lhe das mãos. Se você ataca a ortodoxia dogmática, Vladímir Soloviov ${ }^{223}$ ergue na sua frente a ortodoxia evolucionista; o mujique não se preocupa nem com um nem com outro e satisfaz-se simplesmente com a tradição, com a igreja, com uma fé inabalável - e ele ainda é o menos insensato. Como nos identificarmos nisso tudo?

“Os socialistas divertem-me com a própria pretensão de conhecer o futuro: como se uma teoria, por mais nova que ela seja - e trata-se da teoria econômica ou materialista da história - pudesse algum dia permitir prever o que quer que seja! Escuto dizer que os trusts vão facilitar a socialização dos meios de produção; é possível: mas não está nada certo; pessoalmente, vejo nos trusts apenas uma ameaça de uma terrível crise e o provável retorno a uma realidade bastante semelhante à realidade atual, ou seja à propriedade individual. Conheço apenas um único meio de melhora social: curar os males presentes no exato momento em que sofremos com eles, e cada um sabe bem onde o calo lhe aperta. Na Rússia, por exemplo, nossos camponeses não possuem terras: que nós lhes demos a terra de que eles necessitam! Mas de que servem as teorias? Além disso, parece-me que elas já estão ultrapassadas e que apenas os homens de espírito estreito ou de cultura pobre insistem nelas. Existem teorias socialistas como existem as modas femininas que, muito rapidamente, saem do salão e são encostadas.

\footnotetext{
${ }^{221}$ Político francês (1871-1918). (N.T.)

${ }^{222}$ Jean Jaurès (1859-1914), líder socialista francês. (N.T.)

${ }^{223}$ Vladímir Soloviov (1853-1900), filósofo, poeta e crítico literário russo. (N.T.)
} 
“Ah! as teorias!... Ainda ontem, no jornal Ruskie Vedomosti ${ }^{224}$, eu lia uma história sobre o automatismo do homem-máquina. Pura verborragia e aberrações isso tudo! Nossos atos não são absolutamente automáticos e não conheço uma só pessoa que não seja influenciada por um dos três seguintes motivos: razão, sentimento ou sugestão; muito raramente a razão, e apenas para os melhores dentre nós; sentimento, quase sempre; sugestão, com muito mais frequência do que podemos crer. O poder da sugestão é imenso, soberano em determinados indivíduos, sobretudo nas crianças. Se homens inteligentes acreditaram na ressurreição de Cristo e na sua ascensão, foi devido à sugestão. Sugerimos tudo o que queremos às crianças; e é nesse ponto que a questão da educação torna-se tão perigosa.

Depois, a conversa continuou sobre esse mesmo assunto, um dos assuntos que mais interessam ao fundador da escola de Iásnaia Poliana:

"Outro dia — retomou ele —, uma de minhas sobrinhas-netas veio me dizer: "Tio Lev, eu quero ficar solteirona, e minhas filhas também ficarão solteironas." Devemos respeitar tais ingenuidades, tão inocentemente encantadoras? Parece-me que o mais simples é resolver a questão como o fez Rousseau. Lembra-se da resposta brutal que ele empresta àquela mãe, "mulher tão modesta em seus discursos como em suas maneiras, mas que sabia, conforme as necessidades, pisotear para o bem de seu filho e pela virtude, não se importando com o falso medo das reprovações e as troças das pessoas"? Às perguntas aloucadas das crianças, eu responderia de bom grado como ela, com a firme segurança de que um sentimento de pudor natural impedi-los-á sempre de imputar a seus próprios pais, com imagens de um terrível realismo, aquilo que eles terão aprendido sobre coisas desse tipo.

De modo que, também nesse ponto, Tolstói reconhece Rousseau como seu guia: em outra ocasião, referi-me à tocante sinceridade de modéstia teimosa com que ele faz questão de se proclamar em voz alta discípulo de Jean-Jacques.

“A seguinte pergunta foi-me feita inúmeras vezes: o que é preciso dar para as crianças lerem? O que convém a alguns não convém a outros. Em primeiro lugar, tudo depende da idade, em seguida, da condição social e também do caráter. Os ingleses têm uma resposta pronta: os vinte melhores livros! os cem melhores livros! Trata-se de uma apreciação comercial, "bem inglesa", mas que ninguém, fora da

224 "Notícias Russas", jornal muito popular na época. (N.T.) 
Inglaterra, levará a sério. $\mathrm{O}$ mesmo se aplica à pretensão de se acreditarem insignes propagandistas da fé cristã porque terão impresso dez milhões de Bíblias!

"Quanto à educação religiosa das crianças, ela deve ser concluída com o estudo da Profession de foi du Vicaire Savoyard. Essas poucas páginas contêm tudo sobre o que é preciso ser dito para desmascarar o falso cristianismo; e é por isso que nos é mais cômodo ignorar a Profession do que refutá-la. O final não é tão bom: não conseguimos entender bem o que leva o vigário a continuar a ser padre. Esse final soa falso. Mas todo o resto é excelente."

Depois, como ele havia me perguntado sobre as novidades da França e sobre a agitação religiosa na Bretanha: "Como vocês ainda não conseguiram separar a Igreja do Estado? Essa solução, a única razoável e justa, provoca medo - eu sei — em muitos franceses; mas vocês temem perigos imaginários. Quantos bens deixamos de fazer por medo de perigos que, talvez, nunca virão! Os governos sentem um carinho especial por aquilo que eles orgulhosamente chamam de "medidas de precaução"; e eu defendo que essas medidas de precaução são a fonte de infindáveis males."

A noite está bastante avançada. Lev Nikoláievitch não se cansa de conversar. Ele ri e brinca, faz algumas piadas. Quando a condessa, sua mulher, anuncia-lhe para logo a visita de um amigo de São Petersburgo, personalidade das mais conhecidas, sua face adquire uma expressão de cômico pavor: "Certamente, que venha, eu gosto muito dele... Mas como ele é chato! Tem sempre montes de histórias para contar, e conta-as com muita desenvoltura; enquanto está contando, tudo vai muito bem; mas, quando termina, já não sabemos mais o que dizer."

São quase onze horas da noite. Lev Nikoláievitch senta-se à mesa de jogos: a hábil solicitude de sua mulher e de seus filhos impõe-lhe gentilmente o silêncio forçado daquelas partidas de vinte.

"Como você pode ver, eu sou obediente... Mas que fraqueza é essa, a de se apegar tanto à vida! Somos como esses prisioneiros, ou pacientes de manicômios a quem a liberdade apavora. Às vezes, os vigias levam-nos para fora; eles poderiam escapar facilmente: mas não! por vontade própria, agrupam-se em volta dos vigias; mansamente, eles retomam o caminho de suas prisões. E nós fazemos o mesmo, todos nós que estamos vivos: tememos a morte, essa libertação... a morte, abençoada morte..." 